UNIVERSIDADE DE SÃO PAULO

INSTITUTO DE GEOCIENCIAS

\title{
CONTRIBUIÇÃO À GEOLOGIA DE PARTE DA PORÇÃO MERIDIONAL DO CRÁTON AMAZÔNICO: REGIÃO DO RIO ALEGRE, MT.
}

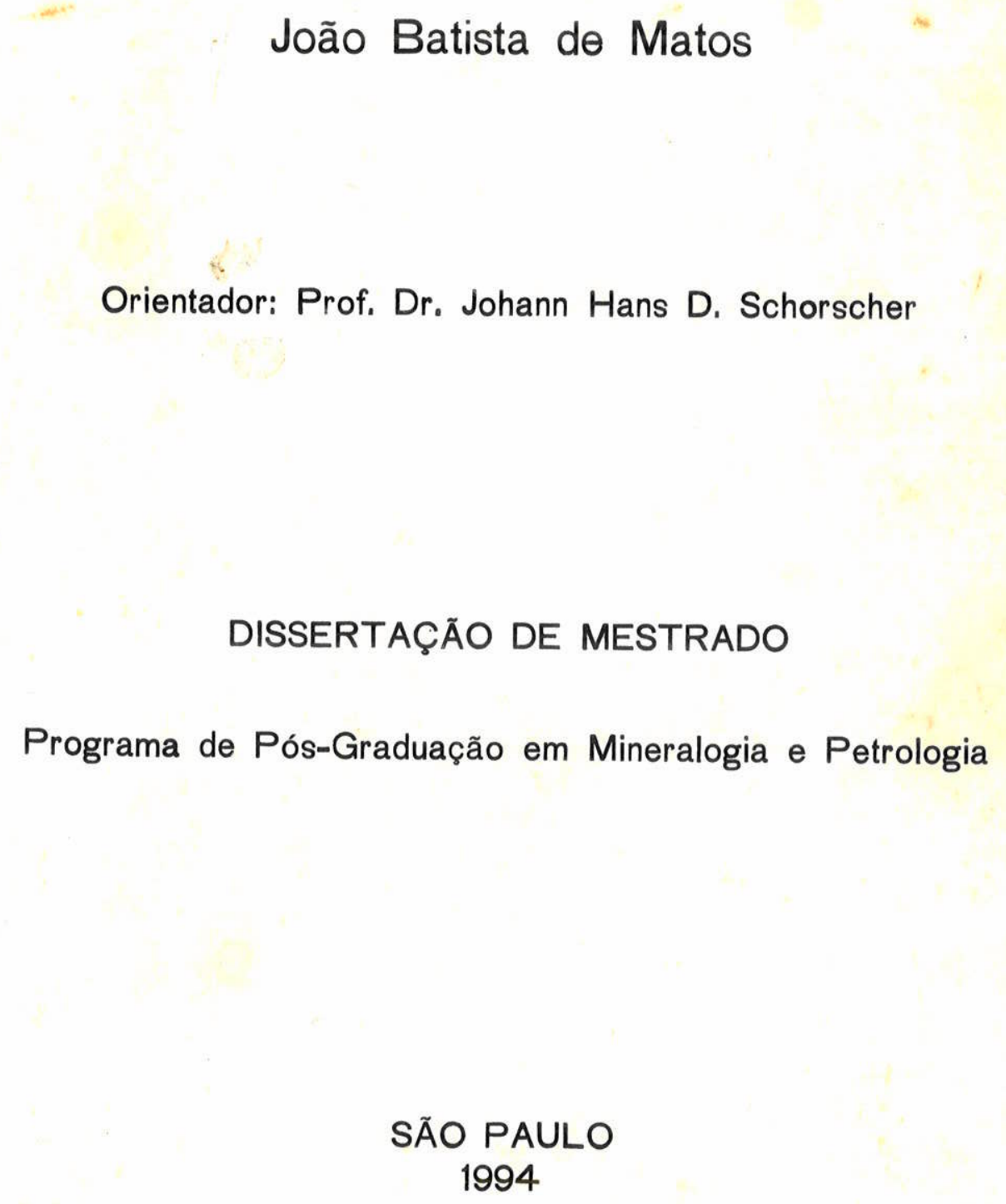




\section{UNIVERSIDADE DE SÃO PAULO INSTITUTO DE GEOCIENCIAS}

\section{CONTRIBUIÇÃO À GEOLOGIA DE PARTE DA PORÇÃO MERIDIONAL DO CRÁTON AMAZÔNICO: REGIÃO DO RIO ALEGRE, MT.}

João Batista de Matos

Orientador: Prof. Dr. Johann Hans D. Schorscher

DISSERTAÇÃO DE MESTRADO

COMISSÃO JULGADORA

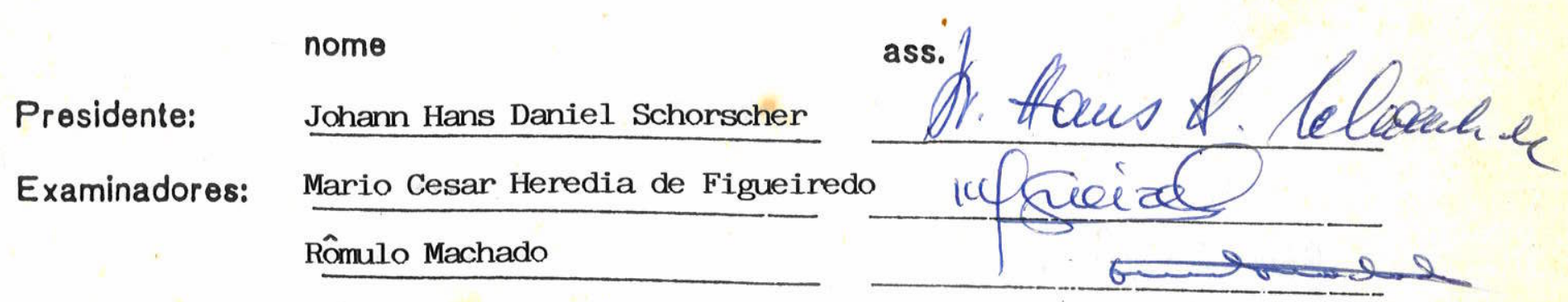




\section{UNIVERSIDADE DE SÃO PAULO \\ INSTITUTO DE GEOCIENCIAS}

\section{CONTRIBUIÇÃO À GEOLOGIA DE PARTE DA PORÇĀO MERIDIONAL DO CRÁTON AMAZÔNICO: REGIÃO DO RIO ALEGRE, MT.}

João Batista de Matos

Orientador: Prof. Dr. Johann Hans D. Schorscher

DISSERTAÇÃO DE MESTRADO

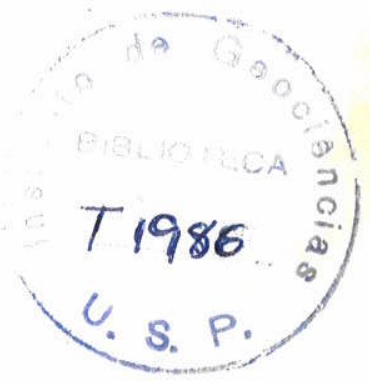

Programa de Pós-Graduação em Mineralogia e Petrologia

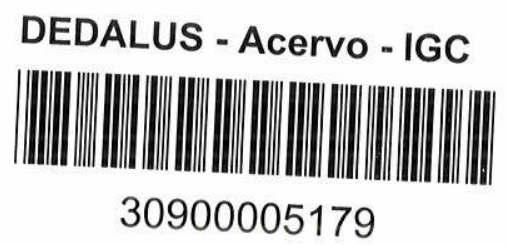

SÃO PAULO

1994 
Dedico a meu pai Plácido Pinto de Matos (In Memórian), que foi para mim, o melhor exemplo de honradez e dignidade. Tento seguir o seu exemplo 


\section{AGRADECIMENTOS}

Desejo expressar os sinceros agradecimentos àqueles que, direta ou indiretamente contribuiram para a realização deste trabalho. Contudo, não poderia omitir algumas pessoas e Instituiçôes às quais sinto-me especialmente grato: Ao Prof. Dr. Johann Hans Daniel Schorscher do Departamento de Mineralogia e Petrologia do Instituto de Geociências da Universidade de São Paulo, pela orientação en todas as fases desta Dissertação, nos trabalhos temáticos e de campo e consecução das análises químicas efetuadas na Universidade de Hamburgo, Alemenha.

À minha esposa Tânia e aos meus filhos July'Anna e Daniel pela compreensão e apoio nos momentos mais dificeis.

À Professora Alda Beatriz de Figueiredo, ex-Coordenadora de Ensino de Pós-Graduação da UFMT, pelo apoio material durante a primeira etapa de campo e estimulos ao desenvolvimento da Dissertação.

À Empresa Matogrossense de Mineração (METAMAT) na pessôa do Geol. Antonio João Paes de Barros, ex-Diretor Técnico; e José Roque Soares, motorista, pelo apoio material e logístico durante as etapas de campo.

Ao Prof. Salatiel A. Araújo e aos alunos do curso de Geologia da UFMT, Michaelson A.S. Luz, Manoel C. Costa, Wilson Thibes Pisani Jr., Edmar V. Gripp e Suze Silva Oliveira (Secretária do Departamento de Geologia Geral (UFMT), pela colaboração nos trabalhos envolvendo informática e desenhos.

Aos meus grandes amigos Profs. Amarildo Salina Ruiz e Nélson Marinho de Oliveira pela leitura atenta, correção de parte do texto e estímulo nos momentos mais importantes.

Aos demais colegas do Departamento de Recursos Minerais e Geologia Geral da UFMT: Alteredo O. Cutrim, Álvaro P. Quadros, Antonio B. Vecchiato, Aquiles Lazzarotto, Cléverson Cabral, Gérson S. Saes, Jayme A. D. Leite, Joaquim Goulart Jr., José da Silva Luz, José Domingues Godói Fillho, Maria Zélia Aguiar Souza, Ricardo K. Weska, Saiyid N. Raza, Serafim C. Melo e Zacarias Mayal Filho pelo estímulo a mim dispensado. parte do texto e incentivos

À Profa. Dra. Raquel Quadros da UFMT pela leitura atenta, correções de

À Profa. Dra. Jacinta Enzweiler e Simone A. Leite, responsável pelo Laboratório de Geoquímica da UNICAMP e estagiária, respectivamente, pela
colaboração em trabalhos laboratoriais.

Ao Prof. Dr. Bernardino R. Figueiredo, Diretor do DGM/UNICAMP pelas facilidades de trabalho a mim proporcionadas junto àquela Instituição.

Ao Prof. José Carlos de Arruda, ex-Diretor do Instituto de Ciências Exatas e da Terra - ICET/UFMT pelo apoio material durante uma das etapas de
laboratório. 
Aos funcionários da Seção de Laminação do IG-USP e do Departamento de Recursos Minerais da UFMT, pela excelente qualidade das seçð̃es delgadas.

À todos os colegas de pós-Gradua̧̧ão do IG-USP, especialmente Ivanir Luchesi, Caetano Juliani, Jayme Presser, Gianna Garda e Marly Torres, pela amizade a mim demonstrada.

Ao amigo Howard Peter K. Davies pela inestimável ajuda durante as etapas de laboratório.

Ao Prof. Dr. Dharani Sundaran da UFMT pela leitura atenta, criticas e sugestões.

Ao Conselho Nacional de Desenvolvimento Científico e Tecnológico CNPq. pela concessão de uma pequena parte dos recursos necessários ao desenvolvimento da primeira etapa de campo (Processo 405600/87).

À todos aqueles que incentivaram e criticaram (construtivamente) o meu trabalho, deixo os meus melhores agradecimentos. 


\section{RESUMO}

O presente trabalho é o resultado de um mapeamento geológico efetuado na escala 1: 100.000 , em área de $220 \mathrm{~km}^{2}$ na regiâo do Rio Alegre, município de Porto Esperidião, sudoeste do Estado de Mato Grosso. A área do estudo apresenta três unidades geomorfológicas assim distribuidas: a primeira é formada pela Serra de Santa Barbara onde ocorrem extensas "cuestas" e cotas ao redor de 1.000 $\mathrm{m}$; na segunda săo destacadas as Serras Alinhadas, representando o relevo dobrado, com cotas de até $800 \mathrm{~m}$; a terceira, onde ocorre um relevo arrasado (cotas de aproximadamente $350 \mathrm{~m}$ ) e constitui a Superficie Cristalina do Guaporé.

Regionalmente, são observados três grandes conjuntos litológicos: Complexo Metamórfico do Alto Guaporé, Greenstone Belt do Alto Jaurú e Intrusivas Associadas; e Coberturas de Plataforma. Localmente, os conjuntos litoestratigráficos são assim constituídos: a) Complexo Metamórfico do Alto Guaporé, representado, entre outros, por gnaisses tonalítico-trondhjemíticos peraluminosos arqueanos, b) Sequêtncia Vulcano-Sedimentar do Rio Alegre e Intrusivas Associadas, subdividida em três conjuntos principais: Formação Minouro, composta por rochas vulcânicas básicas metamorfizadas na fácies dos Xistos Verdes; Formação Santa Isabel, constituída por rochas vulcânicas e piroclásticas de composição intermediária a ácida (lavas e tufos de composição riolítico/daciticos); e Formacăo Săo Fabiano, caracterizada por rochas metassedimentares clásticas, químicas e metavulcanoclásticas.

As rochas intrusivas constituem complexos diferenciados gábricos e serpentiníticos com texturas cumuláticas, metamorfizadas na fácies dos xistos verdes. Elas distribuem-se nas porçöes central e leste da área, fisicamente separadas pela Serra Salto do Aguapeí. Ainda na sua porção oriental, ocorre um batólito monzogranítico denominado Granito-Gnaisse Santa Helena, provavelmente de idade meso-Proterozóica. O metamorfismo regional que afetou essas unidades, possui caracteristicas barrovianas, com possível idade pós-Aguapeí.

Estudos geoquimicos foram efetuados em rochas da Sequeencia Vulcano-Sedimentar do Rio Alegre e Intrusivas Associadas. As rochas metabásicas a meta-intermediárias possuem características sub-alcalinas, sendo que os termos efusivos representam litotipos de fundo oceânico gerados em bacias de retroarco. As rochas efusivas apresentam alterações mineralógicas típicas de processos aloquímicos/hidrotermais/metassomáticos pré-metamórficos do tipo epidotização, espilitização e subordinadamente carbonatação e sericitização, interpretadas como alterações de fundo oceânico. As rochas máfico-ultramáficas intrusivas exibem evolução/diferenciação toleiítica, com anomalias de Cobre, Zinco, Crômio e Níquel que indicam seu possivel potencial metalogenético. 


\section{ABSTRACT}

This work is the result of geological mapping in the 1: 100.000 scale, covering an area of $220 \mathrm{~km}^{2}$ in the Rio Alegre region, Porto Esperidião District, Mato Grosso State.

In the area studied, three geomorphic units are presents and distributed in the following manner: the first is represented by Serra de Santa Bárbara, where extensive "cuestas" occur, with altitude of about $1.000 \mathrm{~m}$; the second is comumently known as Serras Alinhadas with about $800 \mathrm{~m}$ of altitude and the third one with low relief of $350 \mathrm{~m}$ and constitutes the Superficie Cristalina do Guaporé.

The region hosts three major litho-structural units named Alto Guaporé Metamorphic Complex, Alto Jaurú Greenstone Belt and Associated Intrusions and Platform Covers. Locally, these units are represented by associations of tonalitic-trondhjemític and peraluminous archean gneisses; volcanosedimentary sequences of archean origins, subdivided into three principal sub-units: Minouro Formation with basic volcanic rocks, metamorphosed in the greenschist facies; Santa Isabel Formation, with intermediate and acid lavas and pyroclastic rocks; and São Fabiano Formation, characterized by metassedimentary rocks, chemical metasediments and metavolcanoclastic rocks.

The intrusive rocks constitute differentiated gabbroic to serpentinitic complexes with cumulus textures, metamorphosed in the greenschist facies. They occur in the central and eastern parts of the area, separated by the Serra Salto do Aguapel. Still in eastem part of the area occur a monzogranitic batholith of regional dimension and middle Proterozoic minimum age, named Santa Helena GraniticGneiss. The Platformal Covers are represented by the quartzitic, pelitic and conglomeratic metasediments of the Aguapei Group. The principal regional metamorphism wich affected all these units had barrovian medium to upper greenschist facies characteristics and a post-Aguapei age.

Geochemical studies of the volcano-sedimentary and intrusive rocks of the Rio Alegre region indicated subalkaline characteristics for the metabasic and the metaintermediate rocks, where the effusives represent and ocean-floor environment, more probably, of the back-arc basin type. They exhibit mineralogical alteration typical of pré-metamorphic allochemical/hidrotermal/metassomatic process such as epidotization, spilitization and subordinate carbonatization and sericitization, interpreted as of ocean-floor origins. The intrusive mafic and ultamafic rocks, gabbros and serpentinites, with cumulus textures, shows tholeiitic evolution. Copper, zinc, chromium and nickel anomalies in the intrusive complexes are metallogenetically significant. 


\section{ÍNDICE}

\section{AGRADECIMENTOS}

RESUMO

ABSTRACT

Índice

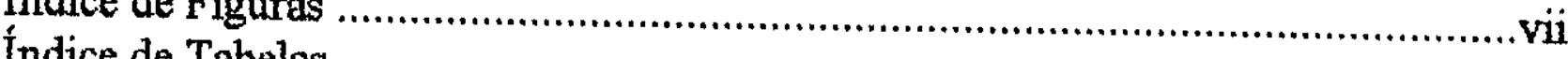

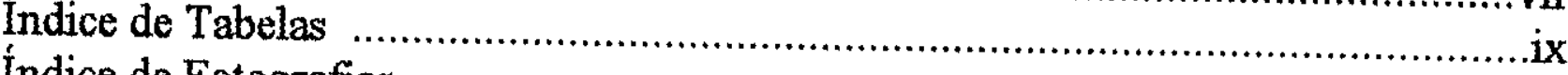

Indice de Fotografias .................................................................................

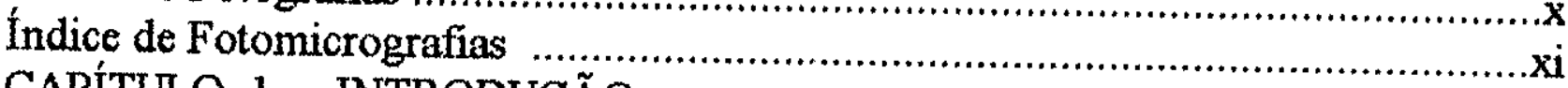

CAPÍTULO 1 - INTRODUÇÃO

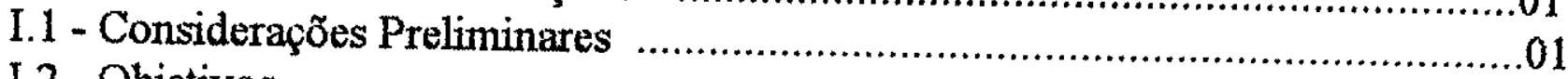

I.2 - Objetivos

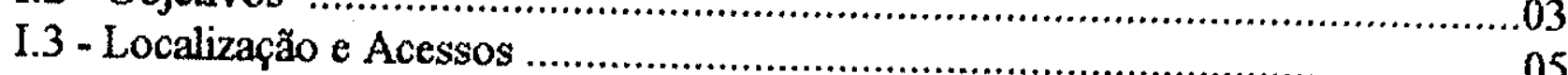

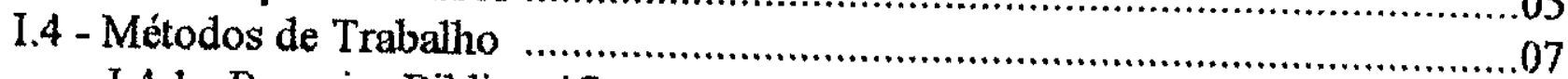

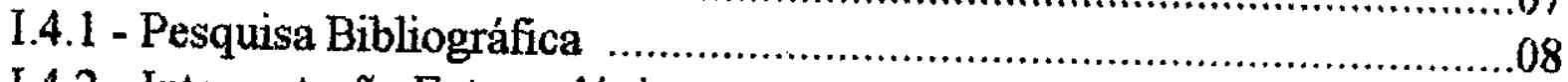

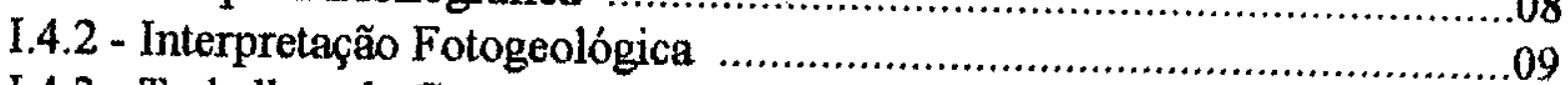

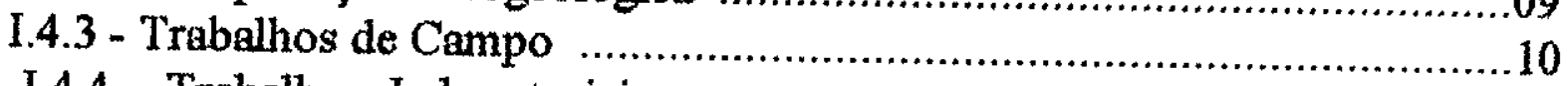

1.4.4 - Trabalhos Laboratoriais ……………………………….............11

CAPÍTULO II - EVOLUÇÃO DO CONHECIMENTO GEOLÓGICO NA REGIÃO SUDOESTE DE MATO GROSSO ……………..........12

CAPÍTULO III - GEOLOGIA REGIONAL .................................................22

CAPÍTULO IV - GEOLOGIA LOCAL ………………………………………...27

IV.1 - Aspectos Geomorfológicos da Área ………………….........................22

IV.2 - Aspectos Gerais do Mapeamento Geológico ……………........................31

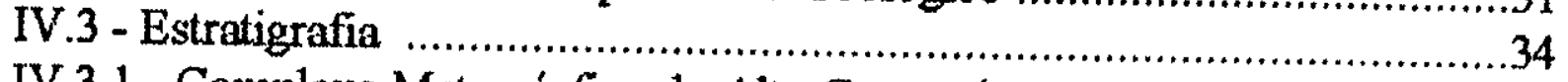

IV.3.1 - Complexo Metamórfico do Alto Guaporé ………………………….....36

IV.3.2 - Seqüência Vulcano-Sedimentar do Rio Alegre e Intrusivas Associadas

IV.3.3 - Granito-Gnaisse Santa Helena

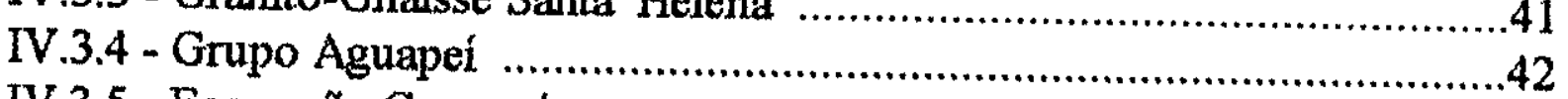

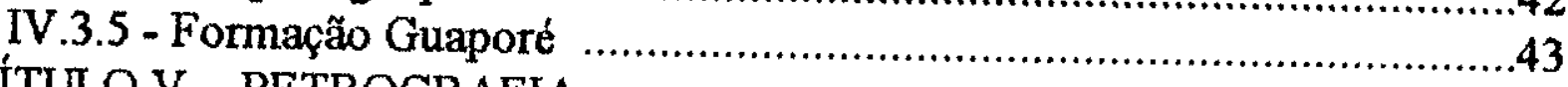

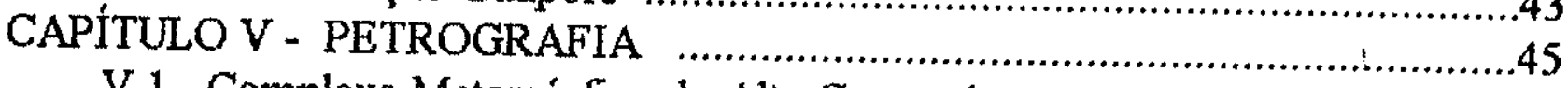

V.1 - Complexo Metamórfico do Alto Guaporé ............................................46

V.2 - Seqüência Vulcano-Sedimentar do Rio Alegre .....................................50

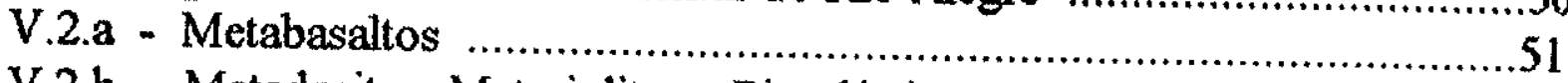

V.2.b - Metadacitos, Metariolitos e Piroclástica ………………………….......58

V.2.c - Xistos, Metacherts e Formações Ferriferas Bandadas...........................

V.3 - Intrusivas Máficas e Ultramáficas Metamorfizadas..................................65

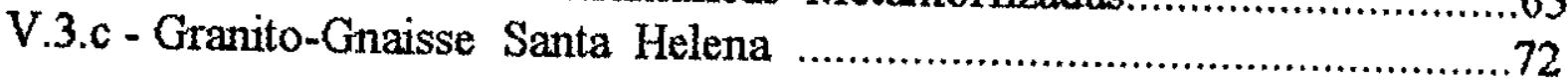


V.4 - Grupo Aguapeí

CAPITULO VI - GEOQUIMICA .75

VI.1 - Seqüência Vulcano-Sedimentar do Rio Alegre

VI.2 - Complexo Gábrico Intrusivo

VI.3 - Complexo Serpentinítico

VI.4 - Diques Metabásicos

CAPÍTULO VII - CONCLUSÕES 


\section{ÍNDICE DE FIGURAS}

Fig. 01 - Mapa de Localização e Vias de Acesso .06

Fig.02 - Esboço Geológico do Sudoeste de Mato Grosso, segundo FIGUEIREDO et. al. (1974).

Fig.03 - Esboço Geológico da Folha SD-21-CUIABÁ, segundo BARROS et. al. (1982).

Fig.04 - Mapa de Compartinentação Geomorfológica do Estado de Mato Grosso segundo LEITE (1989).

Fig.05 - Mapa de Afloramentos

Fig.06 - Quadro Comparativo das Colunas Estratigráficas do Pré-Cambriano no Sudoeste de Mato Grosso

Fig.07 - Esboço Geológico da Região do Rio Alegre

Fig.08 - Diagrama $\mathrm{K}_{2} \mathrm{O}+\mathrm{Na}_{2} \mathrm{O} \times\left(\mathrm{K}_{2} \mathrm{O} /\left(\mathrm{K}_{2} \mathrm{O}+\mathrm{Na2} \mathrm{O}\right)\right) * 100$ (HUGHES, 1973)...82

Fig.09 - Diagrama $\mathrm{Al}_{2} \mathrm{O}_{3} \times \mathrm{TiO}_{2}$ (PEARCE, 1982)

Fig.10 - Diagrama $\mathrm{FeO}^{*}+\mathrm{TiO}_{2} \mathrm{X} \mathrm{\textrm {Al } _ { 2 } \mathrm { O } _ { 3 }} \times \mathrm{MgO}$ (JENSEN, 1976) para rochas efusivas do Rio Alegre.

Fig.11 - Diagrama AFM (IRVINE \& BARAGAR, 1971) para rochas efusivas do Rio Alegre.

Fig. 12 - Diagrama $\mathrm{Na}_{2} \mathrm{O}+\mathrm{K}_{2} \mathrm{O} \times \mathrm{SiO}_{2}$ (IRVINE \& BARAGAR, 1976) aplicado às rochas efusivas.

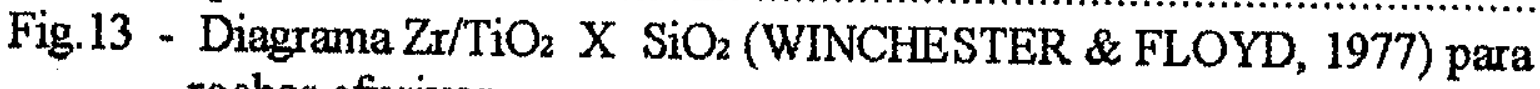
rochas efusivas

Fig. 14 - Diagrama Ti X Cr (PEARCE, 1975) para rochas vulcânicas do o Rio Alegre

Fig.15 - Diagrama V X Ti/1000 (SHERVAIS, 1982) para rochas extrusivas do Rio Alegre.

Fig.16 - Padrões de Variação de Elementos Compativeis e Incompativeis incluindo ETR (TAYLOR \& MCLENNAN, 1985) para rochas metabásicas

Fig.17 - Padrões de Variação de Elementos Compativeis e Incompatíveis incluindo ETR (TAYLOR \& McLENNAN, 1985) para uma rocha intermediária a meta-ácida.

Fig.18 - Padrões de Varia̧̧ão de Elementos Compatíveis e Incompativeis incluindo ETR (TAYLOR \& MCLENNAN, 1985) para rochas metassedimentares clásticas e químicas e metavulcanoclásticas

Fig.19 - Diagrama AFM (IRVINE \& BARAGAR, 1971) para rochas intrusivas 
Fig.20 - Padrões de Variação de Elementos Compativeis e Incompativeis incluindo ETR (TAYLOR \& MCLENNAN, 1985) aplicado às rochas gábricas

Fig.21 - Padrões de Variação de Elementos Compativeis e Incompativeis incluindo ETR (TAYLOR \& McLENNAN, 1985) para rochas serpentiniticas

Fig.22 - Padrões de Variação de Elementos Compativeis e Incompativeis incluindo ETR (TAYLOR \& MCLENNAN, 1985) aplicado aOs diques máficos 


\section{ÍNDICE DE TABELAS}

Tabela 01 - Análises modais de metabasaltos .................................................55

Tabela 02 - Análises modais de vulcanitos ácidos e piroclástica ...........................60

Tabela 03 - Análises modais de xistos, metacherts e BIFs. ...............................64

Tabela 04 - Análises modais de gabros e ultramafitos ....................................71

Tabela 05 - Análises modais de granitóides ...................................................73

Tabela 06 - Análises químicas de rochas metabásicas e meta-ácidas ....................79

Tabela 07 - Análises químicas de rochas metassedimentares clásticas e químicas (BIFs) e metavulcanoclásticas (tufos e tufitos) ...................91

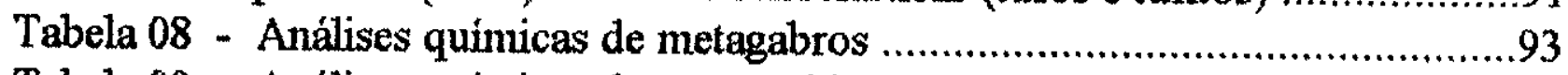

Tabela 09 - Análises químicas de metaperidotitos ........................................96

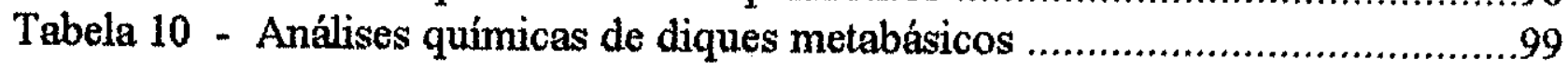




\section{ÍNDICE DE FOTOGRAFIAS}

Foto 01 - Paralelismo do relevo dobrado da Serra Salto do Aguapeí ...................28

Foto 02 - Modo de ocorrência de granitóides no vale do Rio Alegre ...................40

Foto 03 - Aspecto geral da ocorrência de gnaisses do Complexo Metamórfico Alto Guaporé

Foto 04 - Afloramento de metabasalto no Rio Aguapé ....................................52

Foto 05 - Afloramento de dique de diabásio na Fazenda do Japonês .................53

Foto 06 - Outro aspecto do dique enfocado na foto 05 ....................................53

Foto 07 - Afloramento de Formação Ferrifera Bandada da Fazenda Nossa

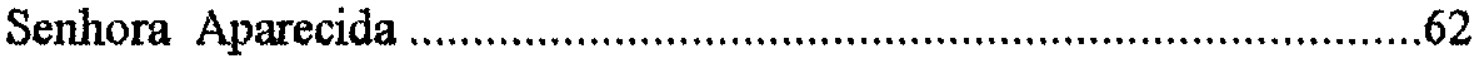

Foto 08 - Detalhe da Fotografia 07 ..........................................................62

Foto 09 - Aspecto Geral do afloramento de serpentinito ................................68

Foto 10 - Detalhe do afloramento retratado na foto 09 ..................................68 


\section{ÍNDICE DE FOTOMICROGRAFIAS}

Fotomicrografia 01 - Gnaisse do Complexo Metamórfico Alto Guaporé .49

Fotomicrografia 02 - Biotita-Gnaisse bandado

Fotomicrografia 03 - Metabasalto com textura blastoporfiritica

Fotomicrografia 04 - Quartzo-metabasalto com foliação incipiente

Fotomicrografia 05 - Preenchimento de fratura com epidoto em metabasalto da Unidade Minouro

Fotomicrografia 06 - Metatufo lítico com fragmentos lapili

Fotomicrografia 07 - Detalhe da fotomicrografia anterior

Fotomicrografia 08 - Formação Ferrifera Bandada

Fotomicrografia 09 - Metatufito da S.V.S. do Rio Alegre

Fotomicrografia 10 - Metadiabásio intrusivo na Seqüência V.S. do Rio

Alegre

Fotomicrografia 11 - Textura cumulática com foliação incipiente (NP) em metaperidotito

Fotomicrografia 12 - Textura cumulática com foliação incipiente (NX) em metaperidotito

Fotomicrografia 13 - Textura cumulática em metaperidotito (NP)

Fotomicrografia 14 - Textura cumulática em metaperidotito (NX)

Fotomicrografia 15 - Textura isótropa no Granitóide Santa Helena

Fotomicrografia 16 - Evidências de recuperação/recristalização nos quartzitos Aguapeí

Fotomicrografia 17 - Recristalização parcial de quartzo em meta-ruditos cataclásticos do Grupo Aguapeí 


\section{CAPÍtULO I}

\section{I.1 CONSIDERAÇÕES PRELIMINARES}

A área deste trabalho situarse na porção meridional do Cráton Amazônico, distando aproximadamente $100 \mathrm{~km}$ a sul da cidade de Pontes e Lacerda e cerca de $50 \mathrm{~km}$ da linha de fronteira com a República Boliviana.

O Estado de Mato Grosso desde o inicio de sua colonização, caracterizou-se por uma intensa cobertura vegetal, estendendo-se por toda a parte territorial compreendida pela Amazônia Legal desta unidade Federativa. Naturalmente, dentro desse quadro, o desenvolvimento da pesquisa de recursos naturais e do conhecimento geológico não eram favorecidos, isso porque os ínvios caminhos existentes, não permitiam os rápidos deslocamentos entre os núcleos populacionais, oferecendo grandes dificuldades naturais, associados às distâncias dos principais centros comércio-industriais do pais.

Nos anos 70, alguns fatores favoreceram à realização de trabalhos geológicos tais como: a colonização oriunda do sul-sudeste do pais, a abertura de melhores vias de acesso e a disponibilidade de imageamentos $\mathbf{e}$ outros produtos de sensores remotos com tecnologia mais avancada, possibilitaram a realização de alguns trabalhos importantes para o conhecimento geológico da região. O Projeto Alto Guaporé da Companhia de Pesquisa de Recursos Minerais (FIGUEIREDO et al. 1974) foi um dos pioneiros, tendo mapeado a regizo compreendida desde o meridiano $570 \mathrm{~W}$. Gr. até a fronteira com a Bollvia, em escala $1: 500.000$. Nesse trabalho, os autores objetivaram a caracterização litoestrutural o que resultou na elaboração do primeiro mapa geológico regional do sudoeste do Estado de Mato Grosso (Fig. 02).

BARROS et al. (1982), apresentaram o resultado dos trabalhos de reconhecimento geológico desenvolvidos pelo Projeto RADAMBRASIL, Folha SD-21 CUIABÁ em escala $1: 1.000 .000$ que cobre parte da região sudoeste do
Estado de Mato Grosso.

dos principais litotipos que ocorrem na regiano inclusa no contexto geotectônico sđo representados por associą̧es gnaissico-migmatíticas, granitóides de anatexia, 
anfibolitos, sequências vulcano-sedimentares, raros granulitos e ainda coberturas plataformais de idade proterozóica.

A escolha de uma área deste contexto geológico (Fig. 01), deveu-se principalmente às ocorrências de ouro, cobre e niquel existentes na região e pela carência de trabalhos geológicos que caracteriza todo Estado de Mato Grosso, onde os trabalhos mais sismples, tornam-se contribuiçóes significativas, dado o seu caráter pioneiro e fundamental.

Na porção meridional do Cráton Amazônico, o ouro começou a ser explorado pelos portugueses desde o início do século XVII, prosseguindo até o início do século XIX. Até o ano de 1991, a Mineração Manati do Grupo RTZ (Rio Tinto Zinc Ltd.) extrain ouro e cobre na região de Araputanga, distando cerca de $100 \mathrm{~km}$ a leste do Rio Alegre, mineralização também inserida em um contexto geológico-geotectônico muito semelhante ao encontrado na área estudada. 


\section{2 - Objetivos}

A superimposiç̧̃o de eventos tectono-magmáticos, metamórficos e metalogenéticos que se desenvolveram em toda a porção meridional do Cráton Amazónico, com o Estado de Mato Grosso sendo o segundo maior produtor de ouro do país e o primeiro na produção de diamantes, entre outros, avalizam a importância dos conhecimentos de seus aspectos geológicos gerais e suas particularidades. Tendo em vista essa premissa, procurou-se delimitar uma área que fosse representativa dessas caracteristicas, considerando as limitações de trabalho impostas pelas dificuldades naturais que um mapeamento geológico em regióes da Amazónia apresenta, tais como: baixa densidade de afloramentos, pântanos e matas intransponfveis, associados à escassez de recursos materiais e de infra-estrutura no desenvolvimento de um trabalho acadêmico que ainda permitisse estabelecer uma caracterização adequada dos eventos geológicos que predominaram à época de formaça e deformaça de seus conjuntos de rochas. Foi escolhida a area do Rio Alegre (Fig. 01) de cerca de $220 \mathrm{~km}^{2}$ de onde preexistiram registros sobre a ocorrência de conjuntos litológicos arqueanos e proterozóicos e de mineralizações de Au e Cu.

O trabalho também visa prestar uma contribuiça à geologia daquela regiåo enfocando sua constituição lito-estratigráfica e estrutural. Dentre os aspectos mais importantes, pretende-se atingir os seguintes objetivos:

a) Elaboração de um mapa geológico de reconhecimento lito-estratigráfico e estrutural na escala $1: 100.000$ com o detalhamento possivel, consideradas as dificuldades naturais da região.

b) Caracterização lito-estratigráfica da área (conjuntos maiores) incluindo a identificação e descrição detalhada dos litotipos mapeados, granito-gnáissicos metamórficos, supra-crustais, corpos intrusivos associados, bem como das deformações principais a que foram submetidos.

c) Estudos mineralógico-petrográficos e das microestruturas presentes, dirigidos a petrogênese das associações minerais, bem como o relacionamento metamórfico-estrutural entre as rochas do embasamento e a sequêencia supracrustal, consideradas as suas distribuições espaciais.

d) Estudos laboratoriais do quimismo de grupo de rochas selecionadas da Sequêencia Vulcano-Sedimentar do Rio Alegre, com ênfase na associação de rochas 
metavulcânicas (litoquímica de elementos maiores e traços via Fluorescência de raios $\mathrm{X}$ sequencial automática e espectrografia de Absorçđa Atômica).

e) Caracterização petrográfica e geoquímica preliminar das rochas intrasivas máfico-ultramáficas da área. 


\subsection{Localização e Acessos}

A área estudada está localizada na parte sudoeste do Estado de Mato Grosso, área limitrofe entre os municípios de Porto Esperidião e Pontes e Lacerda, entre os paralelos $15^{\circ} 43^{\prime} 17^{\prime \prime}$ e $15^{\circ} 49^{\prime} 14^{\prime \prime}$ S. e meridianos $59004^{\prime} 09^{\prime \prime}$ e $59^{\circ} 15^{\prime} 00^{\prime \prime}$ W. Gr., com aproximadamente $220 \mathrm{~km}^{2}$. Especificamente, situa-se dentro dos limites da folha SD-21 CUIABÁ (ao milionésimo) do encarte cartográfico internacional (Fig. 01).

A distância aproximada de Cuiabá, capital do Estado de Mato Grosso, é de cerca de $420 \mathrm{~km}$ no sentido oeste. A principal conexão rodoviária é a BR-070, pavimentada e com boa trafegabilidade. Nessa, percorre-se um trecho de aproximadamente $350 \mathrm{~km}$ até os limites da Fazenda Adriana. A partir desse ponto, toma-se uma estrada vicinal com extensão de aproximadamente $70 \mathrm{~km}$ até a sede da Fazenda Minouro, na margem direita do Rio Alegre. No contexto da área mapeada, a Fazenda Minouro situa-se em sua extremidade noroeste.

Os deslocamentos internos são efetuados por estradas precárias, interligando as principais fazendas, com péssimas condições de trafegabilidade durante o periodo chuvoso. 

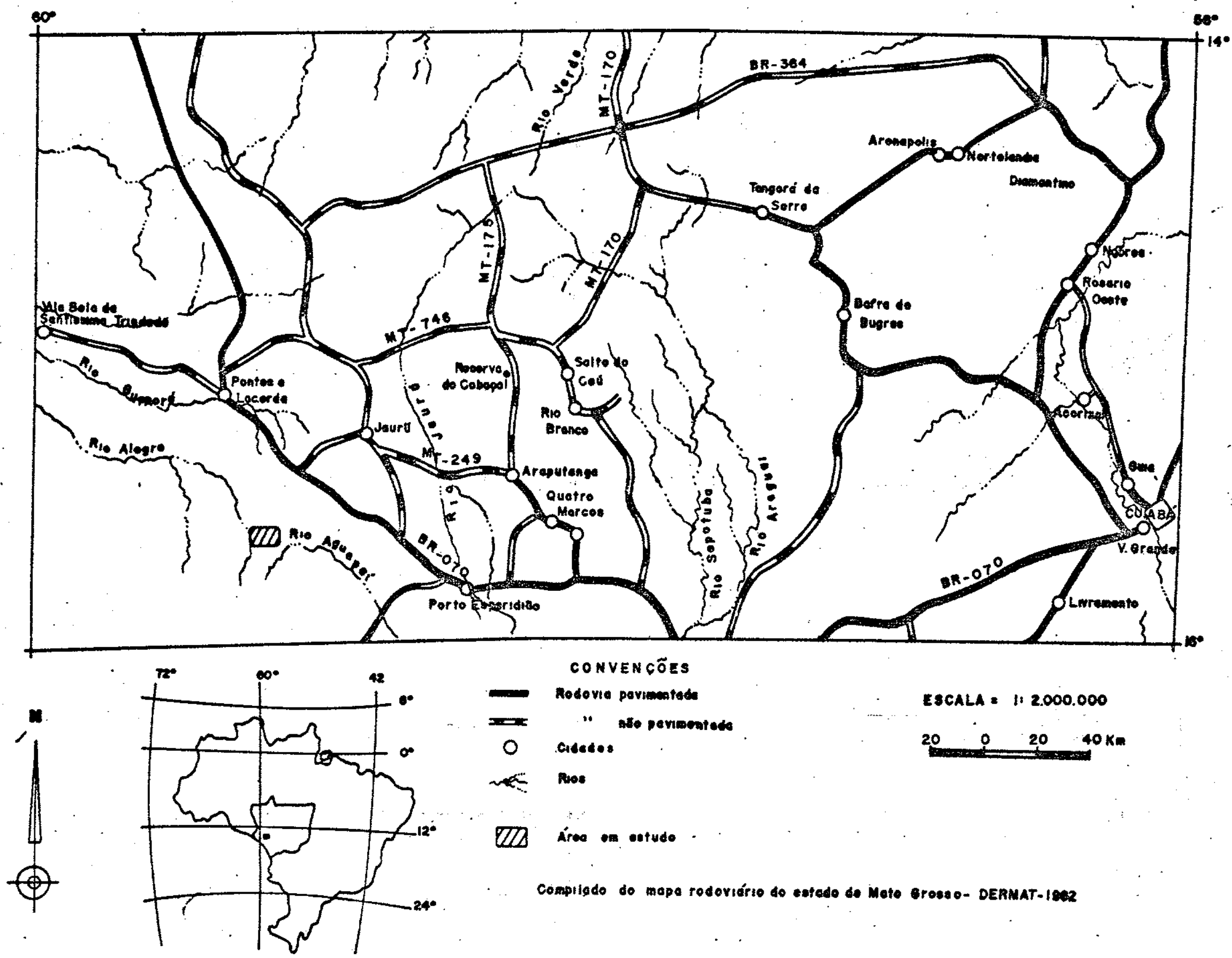

ESCALA $=\|: 2.000 .000$

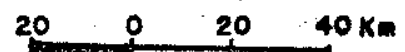

Compilgdo do mope rodoviério 40 eafedo de Meto orosa o- DERMAT-10ee 


\section{I.4. Métodos de Trabalho}

seguintes:

Os métodos de trabalho empregados nesta pesquisa foram os

1) Estudos bibliográficos regionais e temáticos sobre a evolução petrogenética de terrenos granito-greenstone belts.

2) Trabalhos laboratoriais compreendendo interpretação de produtos de sensores remotos TM-Landsat nas bandas 3 e 4, de 02 de julho de 1991, na escala ampliada de $1: 250.000$; mosaicos semicontrolados SLAR -Radambrasil, Folha SD-21-Y-C na escala 1:250.000 e fotografias aéreas (Preto e Branco) efetuadas pela FABUUSAF na escala $1: 60.000$, de 1967. Constaram ainda as análises petrográficas, confeç̧ão de fotomicrografias, análise e interpretação de dados químicos e elaboraçã̃o final da Dissertação. Descrições metodológicas específicas são descritas nos respectivos capítulos V e VI.

3) Trabalhos de campo efetuados em quatro etapas, assim
distribuidas: agosto/87 (10 dias), julho/88 (13 dias), julho/89 (12 dias) e julho/90 (10 dias), totalizando 45 dias nos quais foram coletadas amostras e dados geológicos. 


\subsubsection{Pesquisa Bibliográfica}

Foram efetuados inicialmente os estudos bibliográficos dos trabalhos sobre a geologia da regia sudoeste de Mato Grosso (vide capitulos II e III deste trabalho) e temáticos relacionados à evolução crustal e metalogênese pré-

Com a finalidade espectfica de execução das descriçóes petrográficas, a escolha da bibliografia consultada recaiu sobre as obras clássicas do gênero, que possuem material descritivo fartamente ilustrado para texturas, estruturas e paragêneses minerais tais como: WILLIAMS et. al. (1955), TURNER \& VERHOOGEN (1960), MEHNERT (1971), HYNDMAN (1972), SPRY (1974), DEER et. al. (1977), RAMSAY (1977), WINKLER (1977), TRÖGGER (1979),
BARD (1980) e MacKENZIE et al. (1982), entre outros. 


\subsubsection{Interpretação Fotogeológica}

Os trabalhos laboratoriais com vistas à interpretação de produtos de sensores remotos, precederam as etapas de campo e constaram de uma reinterpretação durante o fechamento do trabalho. As imagens existentes da área, são os produtos de sensores remotos orbitais̀ e de aeronave tais como: Imagens TM-Landsat, bandas 3 e 4, de 02 de julho de 1991, com ampliação até 1:250.000; mosaico semicontrolado de radar na escala 1 : 250.000 (Folha SD-21-Y.C); fotografias aéreas FAB/USAF na escala 1:60.000, efetuadas em 1967; e mapa topográfico na escala 1: 100.000. Este último foi confeccionado em 1973 pelo Ministério do Exército, com base nas fotografias aéreas FAB/USAF.

A base cartográfica final surgiu da integração dos resultados obtidos nos diversos produtos oriundos de sensores orbitais e de aeronave, convertidos à escala $1: 100.000$.

Os materiais referenciados neste tópico compreendem todo o acervo disponivel em termos de imageamento para a área estudada. Neste ponto é importante salientar que boa parte desse material já está ultrapassado. As feições apresentadas não correspondem ao que se observa "in loco", principalmente àquelas referentes à ocupações antrópicas registradas durante os últimos cinco anos. As imagens TM-Landsat praticamente constituem-se no único subsidio verdadeiramente eficaz nos levantamentos de recursos naturais de caráter regional. 


\subsubsection{Trabalhos de Campo}

Os trabalhos de campo iniciaram-se em agosto de 1987 e tiveram continuidade nos seguintes periodos: agosto/88, julho/89 e julho/ 90 , perfazendo um total de 45 dias: Foram descritos 189 afloramentos, com coleta de amostras para petrografia e geoquimica e dados estruturais e estratigráficos na escala 1:100.000. Esse período do ano em que predomina a estação sêca, favorece o desenvolvimento das etapas de campo, não apenas no que concerne à trafegabilidade nas estradas vale do Rio Alegre.

A primeira etapa constou de reconhecimento geológico-regional
preliminar, com visitas a afloramentos principais e levantamento das vias de acesso
e perfis regionais, com coleta de e perfis regionais, com coleta de amostras. Nas etapas subseqũentes foram efetuados novos perfis perpendiculares às estruturas regionais, com amostragem sistemática.

Das amostras selecionadas para fins petrográficos e geoquímicos, foram utilizadas 85 para petrografia. Destas, 25 foram utilizadas para
geoquímica (Fig.05).

Destaca-se a grande dificuldade de trabalho encontrada na área mapeada em função da baixa densidade de afloramentos, espêsso manto de intemperismo e intensa cobertura vegetal nas partes onde ocorre a Seqüência Vulcano-Sedimentar do Rio Alegre, fatores complicadores na elaboração do mapa 


\subsubsection{Trabalhos Laboratoriais}

Os trabalhos de petrografia foram efetuados parcialmente na Universidade de São Paulo e parcialmente na Universidade Federal de Mato Grosso. Foram utilizados microscópios tipo DIALUX (LEITZ) e para confeç̧ão de fotomicrografias os do tipo Standard RP. (ZEISS) existentes nessas escolas e também o ZEISS-JENAPOL (U-TRIN) do Instituto de Geociências da Universidade Estadual de Campinas (UNICAMP).

Para a classificação de litotipos ortoderivados, foi efetuada contagem modal conforme as técnicas descritas em CHAYES (1949). Em média, foram contados a analisados nas rochas equigranulares e inequigranulares com granulação média a fina, 500 pontos por seção delgada. A composição modal obtida foi representada em diagramas QAP convencionais de classificação STRECKEISEN (1976). A composição dos plagioclásios foi estimada através do método de RITTMANN, utilizando os diagramas reproduzidos por TROGER (1979). As rochas paraderivadas foram nomeadas com base na classificação proposta por PETTIJOHN (1975, pag. 211), acrescida do prefixo "meta" e algumas vezes utilizando-se a classificação de rochas metamórficas de WINKLER (1977).

Os traballhos laboratoriais referentes aos estudos geoquímicos que incluíram análises por Absorção e por Fluorescência de raios $\mathrm{X}$, estão descritas no Capítulo VI deste trabalho. 


\section{CAPİTULO II}

\section{EVOLUÇÄO DO CONHECIMENTO GEOLÓGICO NA REGIÃO SUDOESTE DO ESTADO DE MATO GROSSO}

Os conhecimentos sobre a geologia da região sudoeste de Mato Grosso sobrevieram, até meados do presente século, de esparsos relatórios de viagem que continham tão somente descrições sucintas sobre afloramentos de rochas igneas e metamórficas ocorrentes em regiöes adjacentes ao Rio Jaurú e eventualmente portadoras de alguma mineralização. Essa caracterização pioneira foi realizada por pesquisadores desde o ano de 1850 , iniciadas pelo trabalho do conde FRANCIS de CASTELNAU (In CUNHA, 1943) onde aquele autor insere o conjunto de rochas por ele encontrado como parte de um "Embasamento Cristalino".

CUNHA (1943) em expedição também pelo Rio Jauñ e adjacências, descreve uma ocorrência de cobre (malaquita em quartzo) en litologias tais como: homblenda e clorita xistos derivados de gabros, aflorando na região do Morro do Cobre, próximo à localidade de Porto Esperidião (MT).

AHLFELD (1946), AHLFELD \& BRANISA, 1970 (apud CARNEIRO, 1985) descrevem no oriente boliviano, a continuidade do Embasamento Cristalino Brasileiro, de idade arqueana e constitufdo essencialmente por orto e paragnaisses associados a migmatitos, anfibolitos, quartzitos e intrusivas graníticas de idades pré-Paleozóicas.

ALMEIDA (1964) estabeleceu a primeira coluna estratigráfica para a região. Os gnaisses, mica-xistos, anfibolitos e granitos das proximidades do Rio Jauri foram incluidos na unidade regional mais antiga, por ele denominada "Complexo Cristalino Brasileiro".

VIEIRA (1965) considerou em seu trabalho de mapeamento geológico da parte centro-ocidental do Estado de Mato Grosso, os gnaisses e migmatitos do sudoeste matogrossense como parte integrante de uma sequuência denominada "Complexo Cristalino", de idade arqueana, sendo localmente recoberta por basaltos de idade mesozóica. 
A LASA-Engenharia e Prospeç̧ão em 1968 (In BARROS et. al. 1982) incluem "migmatitos e skamitos" como litotipos constituintes do Complexo - Cristalino Brasileiro de ALMEIDA (1964), referindo-se a esse conjunto de rochas com a denominação de "Grupo Jaurín". Esses. autores ainda subdividiram e caracterizaram ambientes de sedimentação das unidades do "Grupo Jauri", ficando assim constitudas: facies neritica, psamítica, representada por uma seqüência quartzo-feldspática, ortoquartzitos, leptinitos e granitos; e fácies batial, pelítica, representada por anfibolitos, xistos e gnaisses.

HASUI \& ALMEIDA (1970) efetuaram estudos isotópicos em rochas graniticas intrusivas da região do Rio Jaurú e circunvizinhanças. Foram determinadas várias idades $\mathrm{K} / \mathrm{Ar}$ e $\mathrm{Rb} / \mathrm{Sr}$ com grande dispersão de valores, indicando granitogênese com idade ao redor de $1.500 \mathrm{Ma}$. As idades mais jovens encontradas foram correlacionadas a eventos posteriores.

AMARAL (1974) através de estudos geocronológicos efetuados na região amazônica, estabelece a existência de três eventos tectono-metamórficos que se desenvolveram no periodo compreendido entre $1.900 \pm 100 \mathrm{Ma}$, até o fim do Ciclo Brasiliano. Foram assim denominados do mais antigo para o mais recente: Paraense (1.700-1.500 Ma), caracterizado por extenso vulcanismo e cobertura sedimentar associada; Mfadeirense (1.400-1.250 Ma), manifestando-se por intenso magmatismo granítico e deformação das coberturas "Paraenses"; Rondoniense (1.050-900 Ma), que teria sido responsível pela existência dos corpos graníticos circunscritos da Amazônia Meridional. Em face da carência de dados, o autor nâo estabelece em qual época teria ocorrido a consolidação cratónica, se durante o Ciclo Transamazônico ou no Ciclo Brasiliano.

FIGUEIREDO et al. (1974) no mapeamento geológico sistemático de partes das Folhas SD-21 CUIABÁ, SE-21 CORUMBA E SD-20 GUAPORÉ, propuseram uma coluna estratigráfica para a região. Esta teve como base os trabalhos de ALMEIDA (1964) e VIEIRA (1965) e os dados do próprio mapeamento efetuado. O Complexo Basal foi proposto como sendo constituído predominantemente por biotita-gnaisses, com variaçđo lateral para hornblendabiotita gnaisses, alternando-se com xistos, quartzitos e leptinitos. Denominaram informalmente de "Intrusivas Básico-Ultrabásicas", corpos ígneos constituídos pelos seguintes litotipos: gabros, gabros anfibolitizados, anfibolitos, peridotitos e serpentinitos, e de "Rochas Graníticas", um conjunto intrusivo formado por corpos elípticos/alongados contendo granitos $3 \mathrm{a}, 3 \mathrm{~b}$ e tonalitos. Definiram ainda um espesso pacote metassedimentar clástico, de ambiente marinho transgressivoregressivo que recobre o Complexo Basal, com a denominação de "Unidade 
Aguapef". Litoestratigraficamente, subdividiram-no em três conjuntos principais: inferior, de natureza psefítica, médio (pelítico) e superior (psamítico).

OLIVATTI \& RIBEIRO FILHO (1976) efetuaram ampla revisão dos conhecimentos obtidos no mapeamento geológico sistemático realizado pela CPRM nos domínios da Folha SD-21 CUIABÁ e circunvizinhanças, tha qual concordam irrestritamente com as proposiçôes geológicas apresentadas por FIGUEIREDO et al. (1974), também reportadas por PADILHA et al. (1974).

ALMEIDA (1978) sugere a denominação de "Cráton Amazônico" para englobar as duas porçôes do Embasamento Metamórfico da região amazônica: a Plataforma do Guaporé na parte meridional e o Escudo das Guianas na parte setentrional. Essas porções encontram-se fisicamente separadas pela sinéclise do Amazonas.

CORDANI et al. (1979), CORDANI ( 1981) e CORDANI \& BRITO NEVES (1982) através de estudos isotópicos desenvolvidos no âmbito do. Projeto Radambrasil, estabeleceram um esquema evolutivo para a região amazônica durante o Proterozóico. Neste periodo, teria havido o amplo desenvolvimento de três cinturôes móveis com alinhamento na direção NW-SE, periféricos a um núcleo cratônico denominado "Amazônia Central". A designação desses cinturōes móveis pela ordem da provincia mais antiga para a mais recente foi a seguinte:

1) MARONI-ITACAIUNAS 2.200 a $1.800 \mathrm{Ma}$.

2) RIO NEGRO-JURUENA 1.700 a $1.400 \mathrm{Ma}$

3) RONDONIANO 1.400 a $900 \mathrm{Ma}$.

CARDOSO et al. (1980) formalizaram a denominação de Formação Jauru aos diamictitos de idade Carbonifera mapeados pela primeira vez por FIGUEIREDO et al. (1974). Nesse trabalho, os autores concordam "in totum" com as interpretaçóes de OLIVATTI \& RIBEIRO FILHO (1976) relativas à um ambiente glacial para essa cobertura paleozóica.

SOUZA \& HILDRED (1980) propuseram a denominação de "Grupo Aguapei" às coberturas metassedimentares detríticas proterozóicas que ocorrem dominantemente no sudoeste do Estado de Mato Grosso. Os membros: Inferior, Médio e Superior da "Unidade Aguapei" de FIGUEIREDO et al. (1974) foram denominados de Formação Fortuna, Formação Vale da Promissão e Formação Morro Cristalino, respectivamente. Trata-se de uma seqüência transgressivo-regressiva plataformal, também descrita pela LASA-Engenharia e Prospecções S/A (1968) sob a denominação de "Grupo Cubencraquén" (BARROS et al. 1982) e em seguida, designada "Unidade Aguapei" no trabalho desenvolvido por FIGUEIREDO et al. (1974). Esta última denominação obteve a concordância de RIBEIRO FILHO et al. (1975) e OLIVATTI \& RIBEIRO FILHO (1976). 
DARBYSHIRE et al. (1979); LITHERLAND \& BLOOMFIELD (1981) e LITHERLAND et al. (1989) estabeleceram, na região oriental da Bolívia (fronteira com o Brasil), a presença de sequências de rochas de natureza cristalina com idades do Proterozoico Inferior a Médio. Foram mapeadas as seguintes unidades em ordem cronoestratigráfica: "Grupo Granulitico Lomas Maneches", constitufdo litológicamente por paragnaisses com bandas de leptinitos, granulitos cálcio-silicáticos e peraluminosos, com hiperstênio e cordierita que representaria a unidade mais antiga desse conjunto, com idade $\mathrm{Rb} / \mathrm{Sr}$ em torno de $2.000 \mathrm{Ma}$ Segue-se o Complexo Paragnaisse Chiquitania", constituido por paragnaisses biotíticos, com enriquecimento localizado em granadas e hornblenda, gramulitos a diopsidio, hormblenda e biotita meta-anortositos e xistos com granada e sillimanita. Esse conjunto teria sido deformado e metamorfizado durante o ciclo orogênico San Ignácio (1.800-1.300 Ma). Os autores postulam que este ciclo teria sido o fator determinante dos processos de deposição e posterior deformação do Grupo San Ignácio (xistos pelíticos com "sills" de rochas básico-ultrabásicas, e rochas graníticas associadas), formando um Cinturão Móvel con tendência direcional aproximada $\mathrm{N}-\mathrm{S}$. O último evento tectono-orogenético a afetar a região, teve lugar no fim do Proterozóico Médio, com a deposiçẫo e deformação de tendência WNW das molassas do Grupo Sunsas, intrusão de rochas granitóides e manifestações igneas básico-ultrabásicas. Consideram ainda, que o Ciclo Sunsas estabelecido na região, teve o seu desenvolvimento no período compreendido entre 1.300 e $950 \mathrm{Ma}$.

OLIVATTI (1981) realizou um levantamento dos problemas estratigráficos e geocronológicos da região sudoeste do Estado de Mato Grosso. Efetuou correlações cronoestratigráficas das unidades ali existentes, com aquelas mapeadas no oriente boliviano por LITHERLAND et al. (1981). O autor tece ainda consideraçóes sobre as correlações entre as principais unidades, no que corresponde em parte, àquelas já efetuadas pelos pesquisadores que desenvolveram o Projeto Pré-Cambrico (1979, 1981 e 1989, anteriormente comentados). As correlações são as seguintes: comparou o Complexo Basal brasileiro ao Grupo Granulito Lomas Maneches e ao Complexo Paragnaisse Chiquitania, com idade atribuida ao pré-Cambriano Médio. Já as intrusivas do Complexo Basal foram correlacionadas aos eventos magmáticos dos Ciclos San Ignácio e Sunsas. Grupo Cuiabá é comparado ao Grupo Esquisto, enquanto que o Grupo Aguapeí é correlacionado ao Grupo Sunsas, dada à continuidade fisica dessa unidade, prolongando-se até o território boliviano.

TASSINARI (1981) considera que as idades dos cinturões móveis estabelecidas por CORDANI. et al. (1979) para a região da Amazônia meridional a norte do paralelo $13 \mathrm{~S}$, deveriam ser modificadas em razão das 
reinterpretações isotópicas por ele efetuadas. Dessa forma, o núcleo cratônico denominado Província Amazônia Central teria idade Arqueana. A diferença principal entre os estudos efetuados por TASSINARI (1981) e os de CORDANI et al. (1979) reside também na idade da Província Rio Negro-Juruena que no entendimento de TASSINARI (1981) representa o periodo entre 1.400 e $1.100 \mathrm{Ma}$.

BARROS et al. (1982) correlacionam os biotita gnaisses, anfibolitos, migmatitos e granitóides de anatexia que constituem o "Complexo Basal" de FIGUEIREDO et al. (1974) com o "Complexo Xingú" de SILVA et al. (1974) da região compreendida pelo interflúvio dos rios Araguaia e Xingú. Parte das "Intrusivas Básico-Ultrabásicas" de FIGUEIREDO et al (1974) foram denominadas de "Suite Intrusiva Rio Alegre" e posicionadas no Proterozóico Médio, em razão das idades radiométricas $\mathrm{K} / \mathrm{Ar}$ determinadas (1.250 Ma). Os granitóides intrusivos com formas semi-elípticas (granitos, granodioritos e tonalitos) foram separados como uma unidade denominada "Suite Intrusiva Guapé", do Proterozóico Superior, cujas idades Rb/Sr oscilam por volta de $900 \mathrm{Ma}$

VASCONCELOS (1982) efetnou um estudo geoquimico em sedimentos de corrente e concentrados de batéia na bacia hidrográfica do Rio Alegre, pesquisando os seguintes elementos: $\mathrm{Ni}, \mathrm{Cu}, \mathrm{Co}, \mathrm{Cr}, \mathrm{Pb}, \mathrm{Zn}$ e $\mathrm{Au}$. Contudo, não encontrou quaisquer anomalias relevantes.

Os primeiros pesquisadores a registrarem a presença de uma sequêencia vulcano-sedimentar no vale do Rio Alegre foram NEDER et al. (1984) que a descreveram em seu relatório interno para a Companhia Matogrossense de Mineração-METAMAT. Os seus trabalhos de prospecção, mapeamento $\mathrm{e}$ amostragens, foram direcionados na tentativa de delimitação e compartimentação desse conjunto, que foi informalmente denominado de "Sequência VulcanoSedimentar". Esses autores enfatizam que as rochas existentes no vale do Rio Alegre, anteriormente designadas como: Intrusivas Básico-Ultrabásicas por FIGUEIREDO et al. (1974) e Suite Intrusiva Rio Alegre por BARROS et al. (1982), representariam, de fato, uma sequência vulcano-sedimentar em forma de anticlinório, com eixo orientado na direção NW e metamorfizada na fácies dos Xistos Verdes, com variações à fácies dos Anfibolitos, encaixadas por corpos intrusivos de granitóides anatéticos. Segundo esses autores, na Unidade Sedimentar ocorreriam derrames vulcânicos e piroclásticas ácidas subordinadas, sendo que os metarenitos, metassiltitos e metacherts com sulfetos disseminados seriam os litotipos mais representativos, enquanto que a Unidade Vulcánica estaria representada por metabasaltos anfibolitizados (Fácies Anfibolito), metabasaltos de fácies xisto verde, metadacitos, metatufos, diques de meta-diabásios, ortoanfibolitos, ortognaisses e milonitos. 
SAES et al. $(1984,1986)$ subdividiram, nos domínios compreendidos pela folha Jaurá (SD-21-Y-C-III), o "Complexo Xingú" em três sub-unidades: Associação Gnăissico-Migmatítica Brigadeirinho contendo rochas metamórficas de fácies anfibolito tais como: biotita e homblenda gnaisses, anfibolitos e migmatitos. Os batólitos graníticos intrusivos nessa sequêtencia foram denominados Granito Santa Helena e Granodiorito Água Clara para os corpos de natureza monzogranitica e granodiorítica. A segunda sub-unidade refere-se à Seqüência Vulcano-Sedimentar Quatro Meninas, constituída por um conjunto de rochas vulcânicas e plutônicas (metabasaltos, meta-anortositos, metagabros e xistos magnesianos, metamorfizados na fácies dos xistos verdes, com idade atribuida ao Proterozóico Médio. A terceira sub-unidade teria natureza intrusiva e foi denominada Suite Intrusiva Figueira Branca. onde os litotipos predominantes são representados por dunitos, anortositos, troctolitos e noritos, sem evidências de metamorfismo, pertencente ao Proterozóico Superior. SAES et al. $(1984,1986)$ redefiniram ainda a Suite Intrusiva Guapé de BARROS et al. (1982), como constituída de hornblenda-biotita microadamelitos e microgranitos porfiríticos formando corpos intrusivos semi-elípticos, considerando-a do Proterozóico Superior.

FERREIRA FILHO \& BIZZI (1985), apresentaram resultados de um trabalho petrográfico tealizado na região do Rio Alegre, onde ocorre um corpo de rochas máficas (olivina-noritos, gabro-noritos, leucogabros, anfibolitos e anortositos) parcialmente granulitizadas

CARNEIRO (1985, 1989) tendo concentrado seus trabalhos na região de São José dos Quatro Marcos, sugere que aquela área é parte integrante de uma "faixa deformada" de maior extensão, com gnaisses cinzentos formando o embasamento das rochas supra-crustais e granitóides róseos intrusivos. O autor determina duas gerações de anfibolitos: a primeira ocorrendo como lentes e bandas interestratificadas em gnaisses cinzentos de composição tonalítica; a segunda geração estaria representada por ocorrências de enclaves em rochas granitóides no embasamento e corpos de dimensóes maiores. Determinaçôes radiométricas executadas mostram idades $\mathrm{Rb} / \mathrm{Sr}$ de $1.971+70 \mathrm{Ma}$, com $\mathrm{Sr}^{8 / 7} \mathrm{Sr}^{66}$ inicial $=0,7017$, para os gnaisses cinzentos e $1.472 \pm 19 \mathrm{Ma}$, com $\mathrm{Sr}^{67 /} / \mathrm{Sr}^{86}$ inicial $=0,7037$, para os granitóides róseos. As idades $\mathrm{K} / \mathrm{Ar}$ para os gnaisses cinzentos e anfibolitos indicam valores em torno de $1.500 \mathrm{Ma}$ que, segundo o autor, refletiriam a atuação de um evento terrno-tectônico relacionado à Reativação Parguazense (Ciclo San Ignácio). MONTEIRO et al. (1986), com base em feições geológicas, dados geoquímicos regionais, levantamentos aerogeofisicos $\mathfrak{e}$ dados geocronológicos das rochas que afloram nas porções superiores das bacias 
hidrográficas dos rios Jaurú e Cabaçal, propõem a denominação de "Greenstone Belt do Alto Jaurú" para as rochas metavulcanossedimentares daquela região. Subdividem esse conjunto em três formaçôes denominadas sequùencialmente da base para o topo: Formação Mata Preta, constituida por vulcanitos básicos de caráter toleítico; Formação Manuel Leme, composta por rochas vulcânicas ácidas, com variação lateral à valcânicas intermediárias, associadas à sedimentação pelítico-quimica; e Formaçăo Rancho Grande, possuindo vulcanitos de natureza máfica na base da unidade e sedimentação pelítico-química no topo.

MORAES \& MAKHOUL (1986) identificaram nos seis grupos litológicos encontrados no vale do Rio Alegre, impressões de quatro fases deformacionais com idades pré-Cambrianas. Denominaram a seqüência vulcanosedimentar ali encontrada de "Sequência Vulcano-Sedimentar Rio Alegre", com destaque para os gnaisses tonalitico-trondhjemíticos como fazendo parte do Complexo Basal. Essa sequêencia é correlacionada ao Greenstone Bell do Alto Jaurú de MONTEIRO et al. (1986). Salientam a atuaçăo de intenso magmatismo granítico durante o Proterozóico Inferior a Médio, representado pelo Granito Santa Helena. O magmatismo básico se faz presente através dos diques de diabásio atribuídos ao Proterozóico Superior. Quanto às fases de deformação, as duas primeiras foram relacionadas ao ciclo denominado "Rio Alegre" que teria afetado a sequêencia vulcano-sedimentar e os gnaisses, apresentando metamorfismo de fácies anfibolito. As duas últimas seriam representadas pelo ciclo Sunsas/Aguapei (LITHERLAND et al. 1979), com metamorfismo de fácies xistos verdes e teriam afetado não somente o Complexo Basal como também as coberturas proterozóicas vizinhas (Gripo Aguapei).

LEITE (1989) identifica um conjunto de rochas na região de Indiavaf (MT), com evolução similar à de terrenos granito-"greenstone belt", possuindo três unidades assim constituidas: Unidade Vulcânica Máfica, subdividida em dois grupos com filiações distintas, sendo um de natureza komatítica, representado por komatítos basálticos e outro com tendência toleif́tica, composto por toleiítos normais e ferro-toleiftos, gerados a partir de uma única fonte (fusão parcial seletiva). O metamorfismo desse conjunto é de fácies xistos verdes; Unidade Química; com sedimentos químicos (metacherts e formações ferríferas bandadas) interestratificados aos derrames máficos; e Unidade Vulcânica Félsica, representada por rochas de composição dacítica a riolítica ocorrendo como lentes isoladas em meio aos derrames basálticos da unidade máfica.

PINHO (1990) efetuou estudos petrológicos e geoquímicos ao longo das cabeceiras do Rio Aguapeí (porção sul do vale do Rio Alegre), 
estabelecendo composição tonalítica com filiação cálcio-alcalina para as rochas graníticas e "trend" toleif́tico para os anfibolitos presentes como enclaves nos tonalitos. A autora descreve ainda, granulitos máficos encontrados como xenólitos em monzogranitos e compara a evolução petrogenética da área estudada à de terrenos "granito-greenstone", correlacionando-a ao "Greenstone Belt do Alto Jauru" de MONTEIRO et al. (1986).

MATOS \& RUIZ (1990; 1991) em mapeamento geológico de semi-detalhe de parte da Folha SANTA RITA (SE-21-V-A), regiäo limitrofe entre o Brasil e a Bolfvia, identificaram no Embasamento Metamórfico os seguintes litotipos: gnaisses bandados, gnaisses oftálmicos e migmatitos, invadidos por um corpo granítico de dimensões regionais denominado Granito Lages. Sua composição modal é de granito $3 \mathrm{~b}$, com mega-enclaves de rochas do Embasamento, com variadas dimensões. Caracterizaram ainda a presença de uma seqüência de xistos pelíticos, com intercalaçôes de xistos hematítico/magnetiticos, com variação lateral para magnetita-quartzitos denominada Formação São Fabiano. Esta unidade é separada por nitida discordância estrutural da sequuência plataformal, sobreposta (Grupo Aguapeí). Para os autores, a Formaçấo São Fabiano nada mais representa do que o termo terrigeno da Sequência VulcanoSedimentar do Rio Alegre (MORAES \& MAKHOUL, 1986) em seu prolongamento para sul. Destacaram ainda quatro fases deformacionais sendo que as duas primeiras $\left(F_{1} \quad\right.$ e $\left.F_{2}\right)$ estão restritas ao Embasamento Metamórfico de rochas graníticas e polimetamórficas. As duas últimas fases $\left(F_{3}\right.$ e $\left.F_{4}\right)$ possuem registros na Formação São Fabiano e também no Grupo Aguapei.

MENEZES et al. (1991) em mapeamento geológico da Folha PONTES E LACERDA (SD-21-Y-C), identificam oito unidades litoestratigraficas distribuídas como se segue: Complexo Metamórfico Alto Guaporé, com idade atribuida ao Arqueano/Proterozóico Inferior, constituido por orto e paragnaisses polideformados, metamorfizados na fácies Anfibolito-alto; Complexo GranulitoAnfibolítico de Santa Bárbara, representado por noritos, enderbitos e anfibolitos, que estariam relacionados à remobilizações crustais pré-Transamazônicas; Complexo Metavulcano-Sedimentar Pontes e Lacerda, constituido por anfibolitos de fácies xistos verdes, resultantes da extrusão de lavas basálticas e rochas de natureza pelito-psamíticas associadas, com idade atribuída ao Proterozóico Médio; Granito-Gnaisse Santa Helena de idade Proterozóica Média, incluindo granitos sin e pós-tectônicos; Granito São Domingos, também relacionado ao Proterozóico Médio, litológicamente composto por granitóides tipo $\mathrm{S}$ (granada-granitos); Suite Intrusiva Rio do Cágado, representada por rochas plutônicas ácidas, intermediárias e básicas, metamorfizadas na fácies dos xistos 
verdes e cronológicamente relacionada ao Proterozóico Médio; Grupo Aguapei, constituido por uma sequência psamo-pelítica do Proterozóico Médio e finalmente; Suite Intrusiva Guapé, com fácies sieno-monzograniticas e quartzo-monzoníticas, com idade relacionada ao Proterozóico Superior. Reconhecem apenas dois eventos tectônicos que afetaram essas unidades: o mais antigo, representado por cisalhamento dúctil sinistral, produzindo foliaçốes miloniticas e cavalgamento de SE para NW em rochas pré-Aguapeí; o mais jovem, com cisalhamento dextral rúptil de direção NNW, presente inclusive nos metassedimentos Aguapeí.

SOUZA (1991) efetua revisão do conhecimento geológico da porçĩo Sudoeste do Estado de Mato Grosso, Sul do Estado de Rondônia e do Leste da República da Bolivia, onde são abordadas questóes petrológicas e geocronológicas daquelas regióes.

RUIZ (1992) em mapeamento geológico realizado na região de Cachoeirinha (MT), separou dois grandes conjuntos litológicos existentes naquela área: Grupo Alto Jaurú, representado por uma sequêencia vulcano-sedimentar do tipo "greenstone belt" e as Unidades Intrusivas representadas pelos Gnaisses São Domingos, de natureza granodiorítica e pelos Gnaisses Aliança, cuja composição é de granito 3b. São ainda representativos desse conjunto as seguintes unidades: Tonalito Cabaçal. Suite Intrusiva Santa Cruz (monzogranitos, sienogranitos e subordinadamente granodioritos) e Suite Intrusiva Alvorada (monzogranitos isótropos). A análise estrutural efetuada pelo autor pressupóe a existência de pelo menos três fases de dobramentos superimpostas, definidas como se segue: $D$, gerando foliação penetrativa, com orientaçăo em torno de N50-60W/60-70NE, com atuação no Grupo Alto Jaurú, Gnaisses São Domingos e Aliança; $D_{2}$, representada por clivagem de crenulação subparalela à xistosidade principal, observada no Tonalito Cabaçal e Suite Santa Cruz, com atitudes em tormo de N50-60W/60-70NE; $\mathrm{D}_{3}$, ocorrendo localmente, onde são descritas evidências de dobras abertas, simétricas e assimétricas, com eixo mergulhando para NE. A foliação plano-axial é representada por una clivagem de crenulação ou de fratura, com orientação $N E$ e vergência para SE.

A figura 06 apresenta a evolução dos conceitos litoestratigráficos do pré-Cambriano para a região sudoeste do.Estado de Mato Grosso.

O presente trabalho abordará questões fuzndamentais sobre as seguintes etapas evolutivas: Embasamento Metamórfico de rochas graníticas polimetamórficas, evolução da Sequêencia Vulcano-Sedimentar do Rio Alegre para a qual admite-se uma evolução do tipo "Greenstone Belt" arqueana e as relações lito-estruturais das unidades arqueanas com as unidades metassedimentares de 
cobertura, do Grupo Aguapei, além dos corpos intrusivos regionais máficos e ultramáficos. 


\title{
CAPÍtULO III
}

\section{GEOLOGIA REGIONAL}

\begin{abstract}
A região Amazónica caracteriza-se por possuir um clima tropical úmido, com desenvolvimento de densas florestas e espesso manto de intemperismo. Disto resulta uma baixa densidade de afloramentos, que dificulta sobremaneira a caracterização de praticamente todos os conjuntos de rochas e principalmente daqueles de maior susceptibilidade ao intemperismo que são as sequiências vulcano-sedimentares que ocorrem na parte meridional do Cráton Amazônico.
\end{abstract}

Cronologicamente, os estudiosos dessa porção do Cráton Amazônico subdividiram as rochas ali existentes em três conjuntos principais: o primeiro deles como o mais antigo, foi sucessivamente denominado "Complexo Cristalino Brasileiro" por ALMEIDA (1964), "Complexo Basal" por FIGUEIREDO et al. (1974), "Complexo Xingú" por BARROS et al. (1982) e "Complexo Metamórfico Alto Guaporé" por MENEZES et al. (1991); o segundo, com denominação de "Sequência Vulcano-Sedimentar Quatro Meninas" de SAES et al.(1984) e posteriomente "Greenstone Belt do Alto Jaurí" por MONTEIRO et al. (1986), sendo que esta unidade possui rochas intrusivas associadas, já abordadas no capitulo anterior. A Seqüência Vulcano-Sedimentar do Rio Alegre, de MORAES \& MAKHOUL (1986), foi inserida por este autor e posteriormente por PINHO (1990) como parte constituinte do Greenstone Belt do Alto Jaurú, tendência esta, seguida neste trabalho; e o último conjunto, compreendendo as coberturas com idades Proterozóicas e Fanerozóicas, Mesozóicas e Recentes.

Nos trabalhos mais recentes, têm-se repetido a concordância de que o Embasamento Metamórfico na citada região, faz-se representar por uma associação gnáissico-migmat́tica, com enclaves e lentes de anfibolitos em alternância com mica xistos, quartzitos e outros litotipos de ocorrência subordinada tais como: cataclasitos, sequuências cálcio-silicatadas (CARNEIRO, 1985) e por granulitos FERREIRA FILHO \& BIZZI (1985), PINHO (1990) e MENEZES et al. (1991) 
O empilhamento desses conjuntos foi tentativamente estabelecido na regiâo de Indiaval-Jaurú por SAES et al. $(1984,1986)$ e LEITE (1989). Nesses trabalhos, os autores propõem uma divisđ̃o do até então denominado "Complexo Xingú" de forma que essa unidade do embasamento ficaria genericamente definida como a seqüencia mais antiga. Segundo esses autores, esse conjunto seria litologicamente representado por gnaisses de composiçâo granodioritica a tonalitica e migmatitos do tipo estromáticos, com melanossoma à homblenda e biotita e neossoma predominantemente granodioritico, com denominação proposta pelos autores de "Complexo Rio Vermelho". Neste trabalho, dá-se preferência à proposição posterior, de MENEZES et al. (1991) que
denomina esse conjunto de "Complexo Metamórfico do Alto Guaporé".

O conjunto intermediário está representado segundo MONTEIRO et al (1986) por derrames de komatiitos, associados a derrames de basaltos toleiiticos que apresentam, eventualmente, estruturas de "pillow lavas" e/ou texturas spinifex, intercaladas com formações ferriferas bandadas, metacheris e uma seqüência de metassedimentos clásticos, nítidamente relacionados à vulcanitos intermediários a ácidos. Todo esse conjunto apresenta-se invadido por rochas intrusivas associadas e está orientado segundo a direção NW-SE e metamorfizado na fácies dos xistos verdes. A Seqüência Vulcano-Sedimentar do Rio Alegre, mais a oeste, foi individualizada por MORAES \& MAKHOUL (1986) e incluída na Sequência Vulcano-Sedimentar Quatro Meninas por LEITE (1989). Nas localidades de Araputanga, Jaurú e adjacências, esse conjunto constitui-se de derrames basálticos, dispostos em faixas orientadas segundo a direção NW-SE e separadas por blocos do Embasamento granito-gnaissico-migmatítico em contatos tectônicos abruptos. Para maiores detalhes, refere-se aos trabalhos de SAES et al. (1984, 1986), MONTEIRO et al. (1986) e LEITE (1989).

Ainda como parte desse conjunto, os granitos fazem-se representar por corpos de dimensốes batoliticas, invadindo tanto as rochas da Sequência Vulcano-Sediementar como as rochas do Embasamento Metamórfico. Os batólitos que ocorrem na parte mais meridional do Cráton Amazônico são os que se seguem: Granodiorito Água Clara e Granito Santa Helena que segundo LEITE (1989), distribuem-se numa extensa porção territorial do sudoeste matogrossense. O primeiro granitóide $\dot{e}$ constituído por litotipos leuco a mesocráticos, com deformação proeminente, apresentando enclaves de anfibolitos, migmatitos e xistos, enquanto que o segundo possui formas semi-elipticas e forte foliação, concordante com as estruturas regionais.

No terceiro conjunto são incluídas as coberturas de plataforma que se fazem representar pelos litotipos detríticos do Grupo Aguapef assim 
constituidos: metaconglomerados, filitos e metarenitos de idade estimada como do Proterozóico Superior FIGUEIREDO et ạl. (1974), SOUZA \& HILDRED (1980), entretanto, trabalhos mais recentes admitem idades do Proterozóico Médio para esta unidade MORAES \& MAKHOUL (1986). LEITE (1989). Este conjunto está ainda representado pela seqüência clástico-química da borda oriental do Cráton Amazônico (Faixa Paraguai), relacionada ao final do Proterozóico Superior e início. do Fanerozóico ALMEIDA (1964), pelos sedimentos glaciais (tilitos) da Formação Jaurí, de idade Carbonifera e pelos sedimentos detrito-psamíticos imaturos, dispostos em camadas horizontais da Formação Parecis, de idade Cretácica. As coberturas Recentes estâo representadas pela ocorrência de sedimentos inconsolidados e lateritas da Formação Guaporé.

As Figuras 02 e 03 respectivamente, mostram os esboços geológicos da parte meridional do Cráton Amazônico, propostos por FIGUEIREDO et al. (1974) e BARROS et al. (1982). 


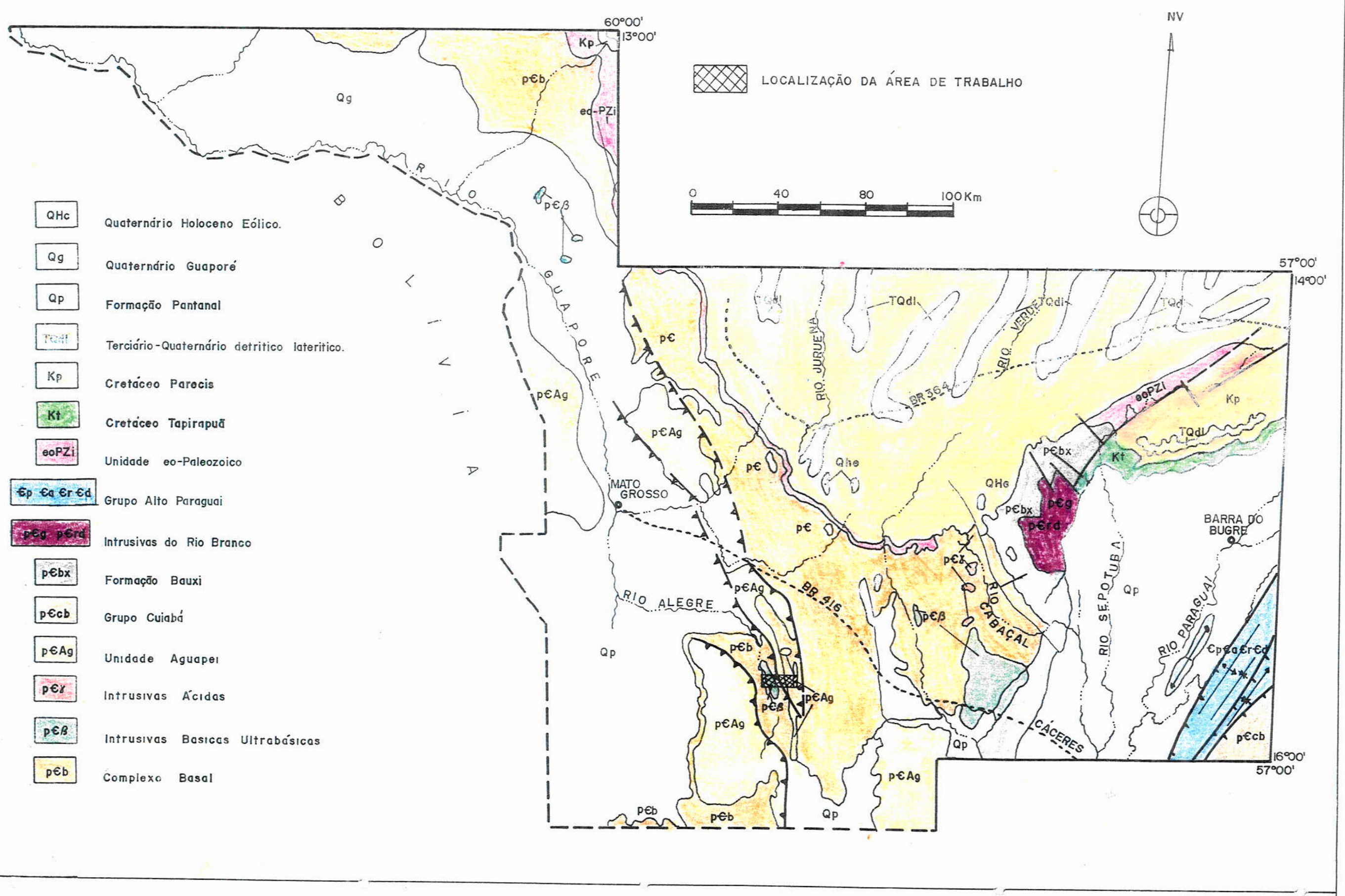


FIG. O3
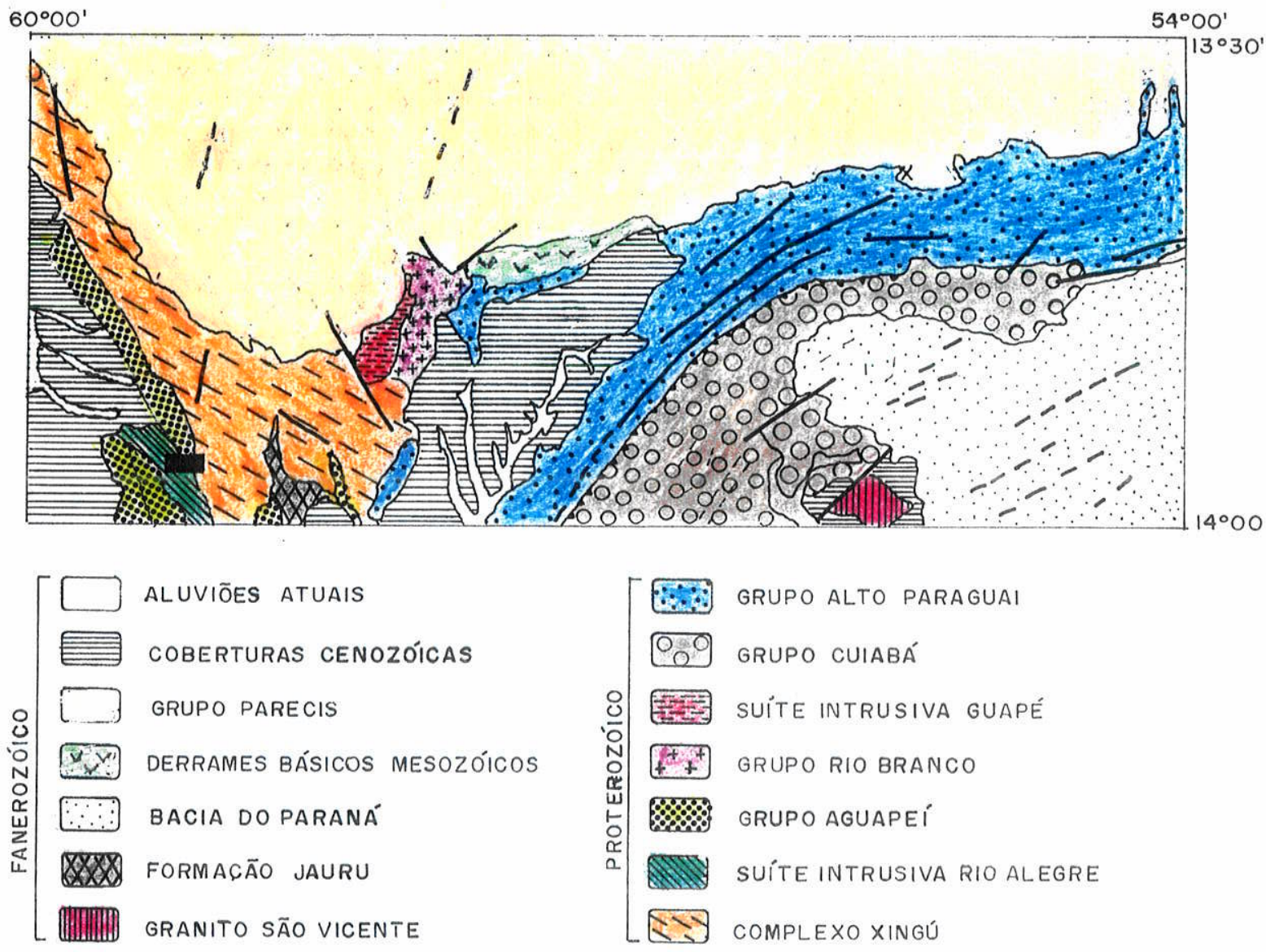

\section{LEGENDA}

ÁREA ESTUDADA

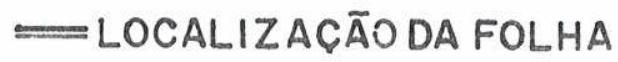

CONTATO ESTATIGRÁFICO

- EIXO DE SINCLINAL COM CAIMENTO

-二 LINEAMENTOS

FALHA DE EMPURRÃO OU INVERSA

FALHA INDISCRIMINADA

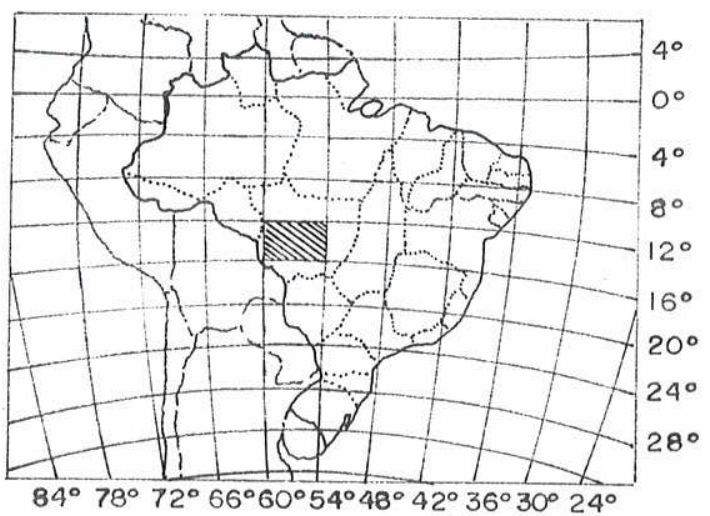




\section{CAPÍTULO IV}

\section{GEOLOGIA LOCAL}

\section{IV-1. Aspectos Geomorfológicos da Área}

O vale do rio Alegre possui em torno de $70 \mathrm{~km}$ de extensão N-S e largura E-W de aproximadamente $15 \mathrm{~km}$. Está topograficamente delimitado a leste pela Serra do Aguapeí e a oeste e sul pela Serra de Santa Bárbara. O Rio Alegre nasce nos contrafortes da Serra de Santa Bárbara e estende-se na dirę̧̃o NW-SE, sendo um dos principais afluentes do rio Guaporé (Bacia Amazônica). Na área estudada, drena a sua parte ocidental, enquanto que as partes E-SE são cortadas pelo rio Aguapeí, afluente do Jauní (Bacia do Prata).

Geomorfológicamente, o vale do rio Alegre é representado por uma superficie arrasada, com cotas altimétricas que variam entre $300 \mathrm{e} 400 \mathrm{~m}$. Nas cotas inferiores, com elevaçôes suavemente arredondadas, afloram tochas do Complexo Metamórfico do Alto Guaporé, da Sequiência Vulcano-Sedimentar do Rio Alegre e ainda, rochas intrusivas associadas. Nas elevações máximas, com altitudes próximas dos $1.000 \mathrm{~m}$, o relevo é formado por cristas alinhadas segundo a direção N20W e os litotipos que proporcionam sustentação a esse relevo são os metassedimentos plataformais quartzíticos do Grupo Aguapei. Esse conjunto é parte de uma extensa faixa dobrada que se prolonga desde o oriente boliviano, atravessa a parte sudoeste de Mato Grosso, atingindo o Estado de Rondônia (Foto 01).

Os tipos litológicos, associados à tectônica e aos ciclos erosivos que tiveram atuą̧ão na região, foram os fatores que contribuíram para o modelamento do relevo atual, podendo ser-identificadas três grandes unidades geomorfológicas (Fig.04), sequencialmente discriminadas conforme as características principais que cada uma apresenta: a primeira unidade é a de Serras Alinhadas (São Vicente, do Agraapeí, da Borda, do Pau-a-Pique, do Caldeiräo e Santa Rita) representado o relevo dobrado (anticlinais e sinclinais fechados) com paralelismo entre cristas e vales, configurando um relevo apalachiano, com formas 


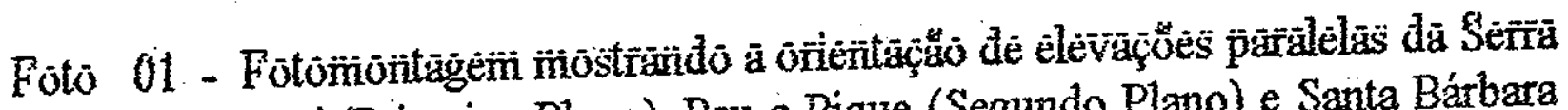
Salto do Aguapei (Primeiro Plano), Pau-a-Pique (Segundo Plano) e Santa Bárbara (Terceiro Plano) constituídos por metassedimentos do Grapo Aguapé (visada de NE para SW do afloramento no 98 , Figura 05). 
mamelonares, dissecadas, com cotas altimétricas em torno dos $800 \mathrm{~m}$; a segunda unidade é formada pela Serra de Santa Bárbara, com cotas altimétricas máximas em torno de $1.000 \mathrm{~m}$, onde ocorrem extensas "cuestas" desdobradas em patamares estruturais, com mergulhos em tomo de $100 / \mathrm{NE}$, configurando uma estrutura do tipo monoclinal, com predominância de relevo dissecado e vegetação marcada pela presença de cerrados ralos; a terceira unidade se apresenta com formas topograficamente arrasadas (cotas altimétricas em torno de $350 \mathrm{~m}$ ) e está presente tanto no vale do rio Alegre como nas demais localidades onde ocorrem rochas do Complexo Metamórfico do Alto Guaporé, Sequêencias Vulcano-Sedimentares e/ou intrusivas associadas. Essa unidade foi denominada por ALMEIDA (1964) de "Superficie Cristalina do Guaporé".

As observações geomorfológicas feitas sobre a área estudada confirmam os resultados de LEITE (1989) para a região maior da Folha CUIABÁ (Fig. 04).

O padrão de drenagem é predominantemente do tipo dendrítico, com aquelas de maior envergadura, escoando paralelamente ao eixo das estruturas regionais proterozóicas (NW-SE).

Os solos dependem unicamente da natureza das rochas subjacentes, podendo ocorrer as variedades latossólicas nas partes mais elevadas, enquanto as "mediterrâneas" predominam nos vales (RIBEIRO FILHO \& FIGUEIREDO, 1976).

Dentro do vale do rio Alegre, grande parte da vegetação primitiva ainda está preservada destacando-se a floresta amazônica ainda intocada, com árvores de grande porte (dezenas de metros de altura) dominando a cobertura vegetal. Pequenas clareiras dentro dessa imensa floresta são representadas por fazendas e pequenos núcleos populacionais em formação, com pouca substituição da mata original por gramíneas e leguminosas, com finalidades ligadas à agropecuária extensiva.

A ocupação antrópica na região remonta à época da descoberta do ouro na Sierra do Aguapeí pelos portugueses no século XVII e como em todo o sudoeste de Mato Grosso, teve seu florescimento ligado à exploração do subsolo, isto é, à busca incansável de minérios existentes em abundância. Tal fator contribuiu significativamente para a constante demanda populacional, sendo de fundamental importância para a fixação do homem naquelas paragens. 
Fig. 4 MAPA DE COMPARTIMENTACĀO gEOMORFOLOGICA DE PARTE DO

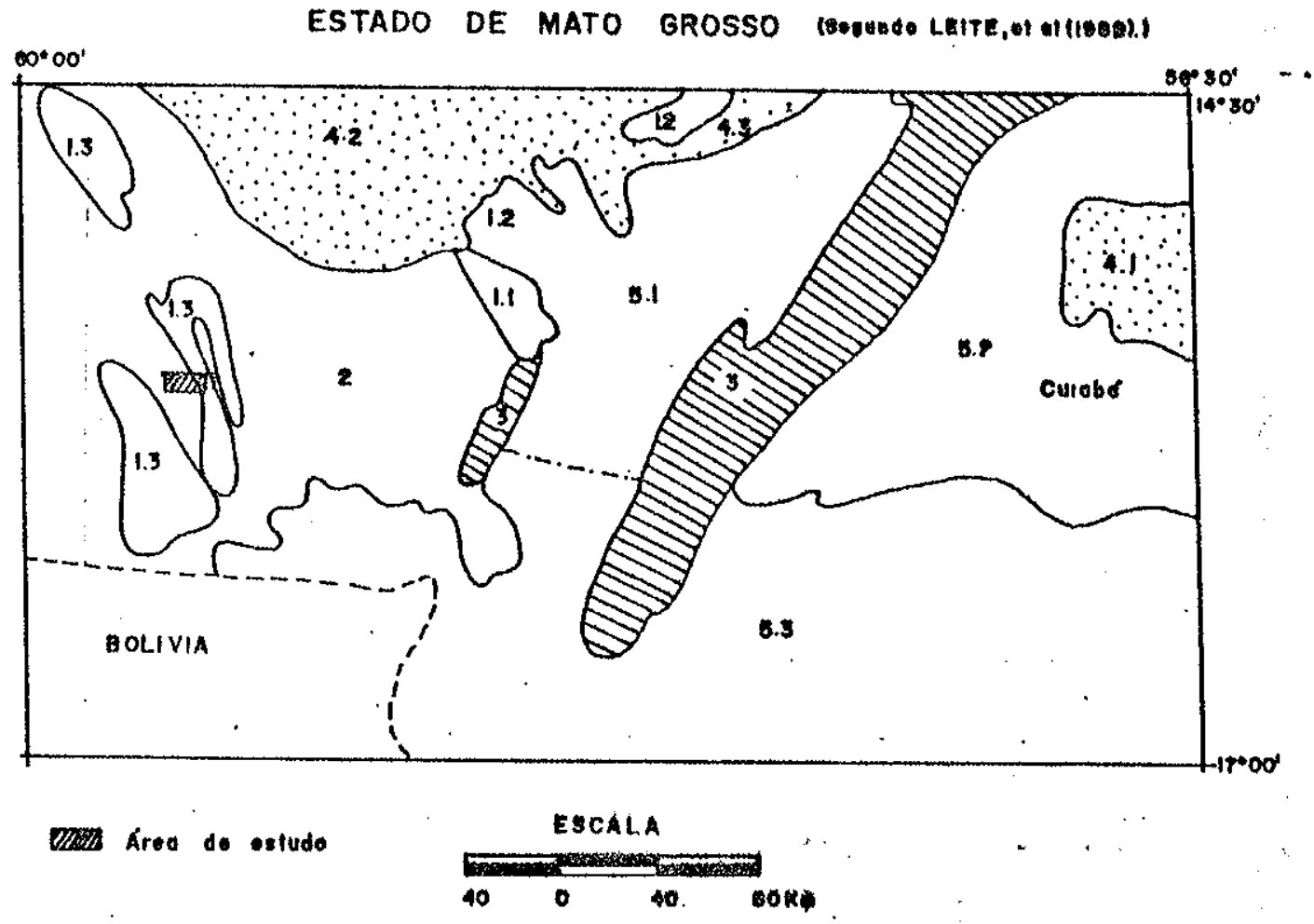

\begin{tabular}{|c|c|c|c|}
\hline \multicolumn{2}{|c|}{ PROVINCIAS } & \multicolumn{2}{|c|}{ DOMÍNIOS } \\
\hline 1 & $\begin{array}{l}\text { SERRANA DO } \\
\text { ALTO GUAPORÉ }\end{array}$ & $\begin{array}{l}1.1 \\
1.2 \\
1.3\end{array}$ & $\begin{array}{l}\text { DAS SERRAS DO ROH- } \\
\text { CADOR } \\
\text { SERAA OE NIO BRANCO } \\
\text { DO AQUAPEI, STA. MITA. } \\
\text { DO CREADO, DA OORDA. } \\
\text { RICARDO FRANCO }\end{array}$ \\
\hline 2 & $\begin{array}{l}\text { SUPERFICIE CRISTALINA } \\
\text { DO GUAPOREE }\end{array}$ & & \\
\hline 3 & SERRANA & & $\therefore$ \\
\hline 4 & DOS CHAPAODES & $\begin{array}{l}4.1 \\
4.2 \\
4.3\end{array}$ & 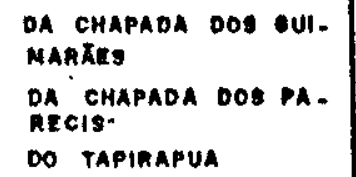 \\
\hline 8 & DO PANTANAL & $\begin{array}{l}8.1 \\
. .2 \\
3.3\end{array}$ & $\begin{array}{l}\text { OA BAIXADA DOALYO } \\
\text { PARAOUAI } \\
\text { DA MAIXADA CUIABAMA } \\
\text { DAS PLANICIES DO PAK. } \\
\text { TAMAL. }\end{array}$ \\
\hline
\end{tabular}




\section{IV.2 Aspectos Gerais do Mapeamento Geológico}

De acordo com os dados geomórficos e climáticos anteriormente apresentados, a espessa cobertura de solo e a intrincada vegetação da floresta amazônica, predominam dentro do vale do rio Alegre e dificultaram enormemente os caminhamentos efetuados durante as quatro etapas de campo necessárias para a caracterização preliminar da área efetuada neste trabalho. Em conseqüência, foi necessária a utilização de todos meios de locomoção disponiveis tais como: veiculos para cobrir grandes distâncias, cavalo para trilhas e áreas desmatadas e barco para levantamento dos afloramentos existentes no leito e margens do rio Alegre.

matacões e lajedos enquanto ques e demais rochas intrusivas ocorrem em forma de dispersas no, interior do vale, em forma de lajedos e também nos ocorrências drenagens. Esse fator, conjugado à pequena densidade de afloramentos existentes em superficie, verificada em lodos os perfis executados, acarretaram em grandes dificuldades com respeito ao detalhamento e à interpretação geológica, já que todos os litolipos bem como seus contatos litológicos estâo literalmente encobertos por vegetação e por um solo uniformemente avermelhado, sem variaçöes macroscópicas características quanto aos diferentes litotipos ocorrentes no subsolo.

Rochas como as variedades graniticas (s.1.) mapeadas, geralmente exibem comportamento isótropo em afloramento, enquanto que as metabásicas e demais componentes metassedimentares da sequêencia vulcanosedimentar, mostram foliação dominante segundo a direção N20W. Os vulcanitos máficos, por vezes, apresentam segregações metamórficas de espessuras milimétricas, de cor esbranquiçada, nos planos de foliação, prolongando-se por dezenas metros de extensão. A mineralogia predonuinante nessas zonas de segregação é constituáda por minerais como epidoto, plagioclásios e, subordinadamente calcita.

Os sulfetos presentes nas unidades máficas e também associados aos metassedimentos vestigiais de formações ferriferas e metacherts, ocorrem de forma disseminada e geralmente são do tipo pirita, pirrotita e calcopirita.

A ocorrência e distribuição dos afioramentos encontrados nos caminhamentos efetuados durante a realização dos trabalhos de campo está representada na figura 05 . Nessa figura, pode-se distingüir uma concentraçäo de pontos em sua parte centro-ocidental, em detrimento das outras porções. Isso se deve aos fatores geomórficos já discutidos no início deste tópico. 
O esboço geológico da região do Rio Alegre, mapeado neste trabalho, é representado na Figura 07. 
Fig. 05

MAPA DE AFLORAMENTOS

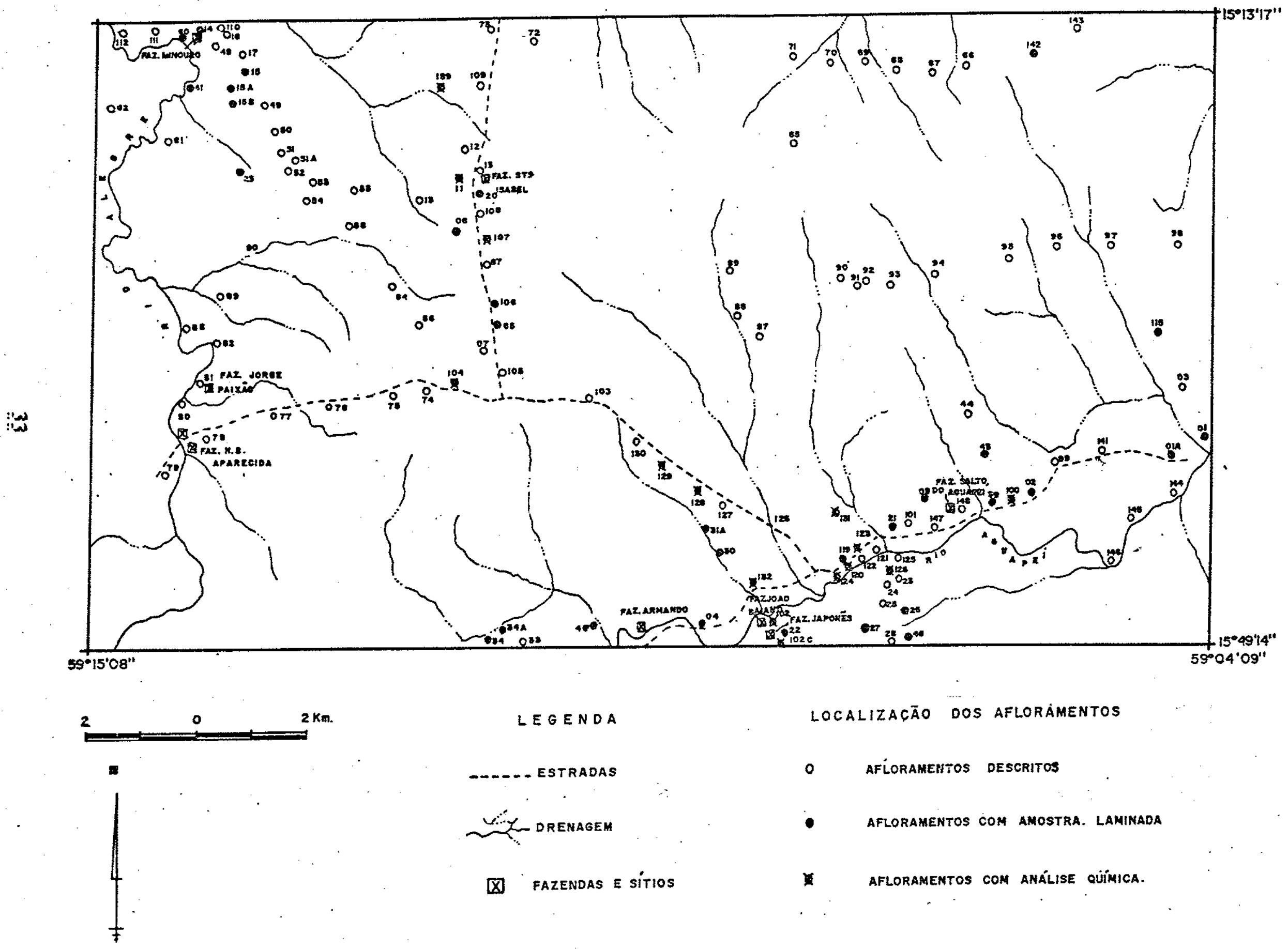




\section{IV.3 Estratigrafia}

A área estudada constitui parte da região sudoeste do Estado de Mato Grosso e como é predominante na grande extensão territorial dessa unidade federativa, os conceitos estratigráficos para as rochas pré-Cambrianas encontram-se em estado de elaboração. Existem, contudo, alguns conceitos já estabelecidos por diversos autores. Estes foram integrados na figura $06 \mathrm{e}$ discutidos nos capitulos II e III.

Neste capítulo, será apresentada a estratigrafia elaborada neste trabalho para a região do Rio Alegre, utilizando sempre que possivel, denominações e conceitos já estabelecidos em trabalhos anteriores, principalmente àqueles utilizados por MENEZES et al. (1991), com a finalidade especifica de evitar proliferação taxonômica.

De acordo com as propostas existentes na literatura, a região estudada compreende as seguintes unidades cronológicamente listadas como se segue: Complexo Metamórfico do Alto Guaporé, Sequência Vulcano-Sedimentar do Rio Alegre e Intrusivas Associadas, Granito-Gnaisse Santa Helena, Grupo Aguapeí e Formação Guaporé. 


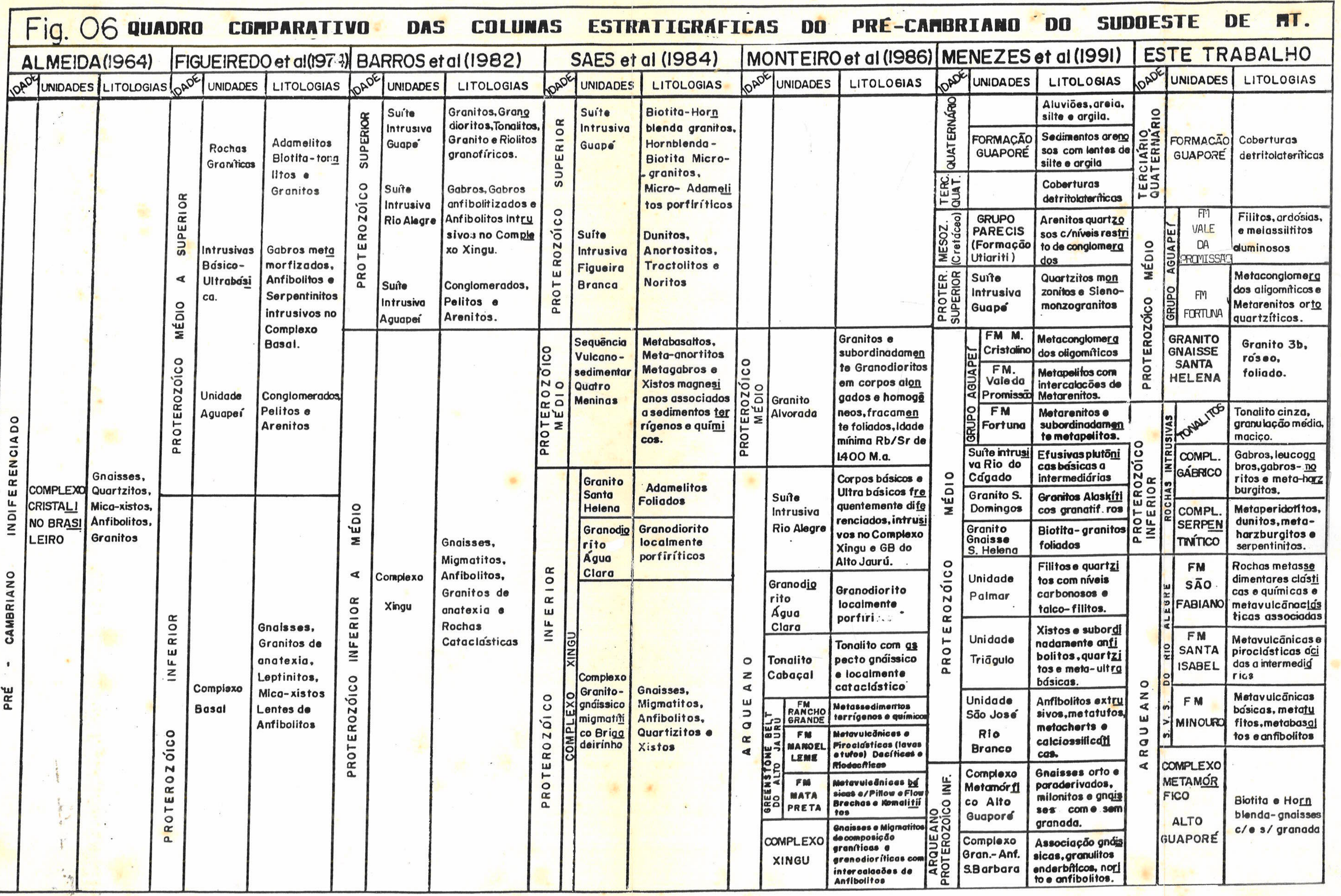




\section{IV.3.1. Complexo Metamórfico do Alto Guaporé}

Adota-se neste trabalho a denominação proposta por MENEZES et al. (1991); na Folha PONTES E LACERDA, para designar a associação de gnaisses cinzas da parte ocidental da área (Fig. 07), já que essas rochas são o prolongamento para sul das litologias mapeadas por MENEZES et al. (1991). Os litotipos mais representativos dessa unidade são os biotita-gnaisses, migmatitos e rochas cataclásticas, ocorrendo em forma de lajedos e/ou matacões distribuidos esparsamente na margem esquerda do rio Alegre. Os gnaisses são separados dos valcanitos máficos da Sequência Vulcano Sedimentar do Rio Alegre, a leste, por contatos tectônicos através de uma falha inversa regional. Para oeste, já fora dos limites da área mapeada, no sopé da Serra de Santa Bárbara, as rochas dessa unidade estão em contato com as rochas, sobrepostas, do Grupo Aguapeí. Este contato não foi verificado em campo durante a execução dos perfís regionais, porém inferido em função dos dados fotogeológicos e estruturais como uma discordância angular e erosiva tectonizada.

Os biotita-gnaisses são rochas foliadas leuco a mesocráticas, de gramulação média a grossa, quase sempre equigranulares, apenas raramente ocorrendo tipos portiriticos. A composição modal é predominantemente tonalítica, podendo ocorrer subordinadamente tipos granodioriticos.

Dentro da área mapeada, o rio Alegre mostra-se, em parte de seu curso, encaixado na falha inversa que separa o Complexo Metamórfico do Alto Guaporé da Seqüencia Vulcano-Sedimentar do Rio Alegre, havendo nas adjacências de suas margens, evidências de movimentação dinâmica tepresentada por gnaisses com foliação/fragmentação cataclástica, preenchimento de fraturas por quartzo e existência de estrias de falha em zonas de silicificação. A interpretação estrutural mais plausível, apesar dos parcos dados de afloramento que a área apresenta, é que o Complexo Metamórfico do Alto Guaporé cavalgue a Seqüência Rio Alegre.

A idade das rochas pertencentes ao Complexo Metamórfico do Alto Guaporé foi atribuida por MENEZES et al. (1991) ao Paleoproterozóico, em. razão da isócrona $\mathrm{Rb} / \mathrm{Sr}$ de $1.971 \pm 70 \mathrm{Ma}$, com $\mathrm{Sr}^{87 / \mathrm{Sr}^{86}}$ inicial $=0,7017 \pm 0,0005$ determinada por CARNEIRO (1985) em gnaisses dos arredores da cidade de São José dos Quatro Marcos. Neste trabalho não foram efetuadas dataçôes radiométricas e, tais dados, inexistem para a área estudada. dessa forma, concordase com o posicionamento crono-estratigráfico proposto para esta unidade pelos autores citados, interpretando, contudo, tratar-se de idades múnimas, superimpostas 
a rochas originalmente do tipo. TTG (Gnaisses e Granitóides Tonaliticos, - Trondhjemíticos e Granodioriticos) arqueanas, no curso dos retrabalhamentos proterozóicos, incluindo a intrusão dos granitóides de São José dos Quatro Marcos. Enfatiza-se ainda, que os valores encontrados por CARNEIRO (1985), são de rochas graníticas intrusivas nos TTG's. 


\section{IV.3.2 Seqüência Vulcano-Sedimentar do Rio Alegre e Intrusivas Associadas}

As rochas da Sequêencia Vulcano-Sedimentar do Rio Alegre, conforme denominadas por MORAES et al. (1986), têm as suas methores exposições nas margens do rio homônimo, nos domínios da Fazenda Minouro (Fig. 07). Foi mapeada como pertencente a esta unidade, uma seqüência de rochas básicas, de derrames em sua maioria, identificados como tais pela alternância concordante com vulcanitos intermediários a ácidos e metassedimentos vestigiais químicos e ternígenos, metamorfizados na fácies dos xistos verdes. Ocorrem ainda corpos intrusivos menores, de sub-vulcanitos básicos (diques), intermediários e ácidos ("plugs" e "stocks").

A Seqüència Vulcano-Sedimentar do Rio Alegre foi subdividida neste trabalho, em três unidades distintas em termos litológico-composicionais e de posicionamento estratigráfico relativo, inferido com base em evidências de campo e por compara̧ões com outras sequêencias vulcano-sedimentares: Formação Minouro, composta por rochas vulcânicas básicas metamorfizadas na fácies dos xistos verdes (metabasaltos e anfibolitos), caracterizada como a unidade basal; Formáção Santa Isabel, constituida por rochas vulcânicas e piroclásticas de composições ácidas a intermediárias associadas (lavas e tufos riolítico/dacíticos), caracterizada como unidade de posicionamento estratigráfico intermediário; e Formação São Fabiano, composta por rochas metassedimentares clásticas e químicas associadas, tais como: sericita xistos, quartzo-sericita xistos, formações ferriferas bandadas e metacherts com pirita. Na Formação São Fabiano ocorrem ainda níveis ocasionais de clorita xistos com magnetita e pirita, associados aos metassedimentos químicos. A denominação desta unidade foi proposta por MATOS \& RUIZ (1990, 1991), tendo sido definida na Folha SANTA RITA (SE-21$\mathrm{V}$-A), contigüa em sua extensão para sul da área deste traballı. Já na Follha PONTES E LACERDA (SD-21-Y-C-II), a norte, essa mesma unidade tecebeu a denominação de "Unidade Paumar" por MENEZES et al. (1991).

As relações de contato da Sequêencia Vulcano-Sedimentar do Rio Alegre com rochas sotopostas não foram observadas em campo, apenas seus contatos laterais por fallhas inversas, separando-a do Complexo Metamórfico do Alto Guaporé. Dessa forma, não foi possivel estabelecer as relações de idades relativas entre as rochas do Complexo Metamórfico do Alto Guaporé e da Sequêencia VujcanoSedimentar do Rio Alegre. As diferenças no grau metamórfico indicam apenas tratar-se de rochas de niveis crustais diferenteș, hoje justapostas.

Os contatos da Sequêtncia Vulcano-Sedimentar do Rio Alegre com as rochas sobrejacentes do Grupo Aguapé também não foram observados em 
função do espesso manto intempérico. Entretanto, apesar da ausência de elementos estruturais (locais) indicativos de falhas (lineamentos estruturais, zona de silicificação, cataclase, etc.) pode-se inferir uma discordância angular e erosiva, visto que o Grupo Aguaper, em estruturas continuas, é sobreposto regionalmente ora às rochas da Sequência Vulcano-Sedimentar do Rio Alegre, ora às rochas do Complexo Metamórfico do Alto Guaporé.

Os litotipos intrusivos na Seqüência Vulcano-Sedimentar do Rio Alegre que afloram dentro da área mapeada constituem-se principalmente de metagabros, gabros anfibolitizados, piroxenitos e serpentinitos. Para essas rochas, BARROS et al. (1982) encontraram idades $\mathrm{K} / \mathrm{Ar}$ de $1.600,1.245 \pm 35$ e $1.227 \pm 25 \mathrm{Ma}$, tendo interpretado a idade de $1.250 \mathrm{Ma}$ como representativa da época de formaçăo dessas rochas, sendo compativel com o pré-Cambriano Superior. Neste trabalho, acredita-se que essas rochas sejam bem mais antigas, uma vez que essas idades $\mathrm{K} / \mathrm{Ar}$ dever refletir o viltimo evento térmico registrado naquela região e que a idade K/Ar encontrada por MONTERO et al. (1986) em gabros da Folha JAURÚ (intrusivos no "Greenstone Belt" do Alto Jaurí), acusou valor de aproximadamente $2,8 \mathrm{Ga}$ (Arqueano).

As rochas de natureza granitica (s.l) ocorrem na área sob a forma de litotipos tais como: granitos $3 b$, granodioritos e tonalitos, esparsamente distribuidos, como pequenos corpos alongados na direção SW-SE, invadindo a Sequiência Valcano-sedimentar do Rio Alegre, cuja principal ocorrência insere-se na parte central da área mapeada, onde se destacam granitos e tonalitos. Os granitos são rochas de cor rosa, mesocráticos, com teor considerável de máficos e classificação modal compreendendo os campos de monzogranito a granodionito, são de ocorrência mais restrita, enquanto que os tonalitos são rochas mesocráticas, com granulação média, possuindo maior ocorrência nas proximidades da Fazenda Santa Isabel (Fig. 07). 
$\overrightarrow{0}$

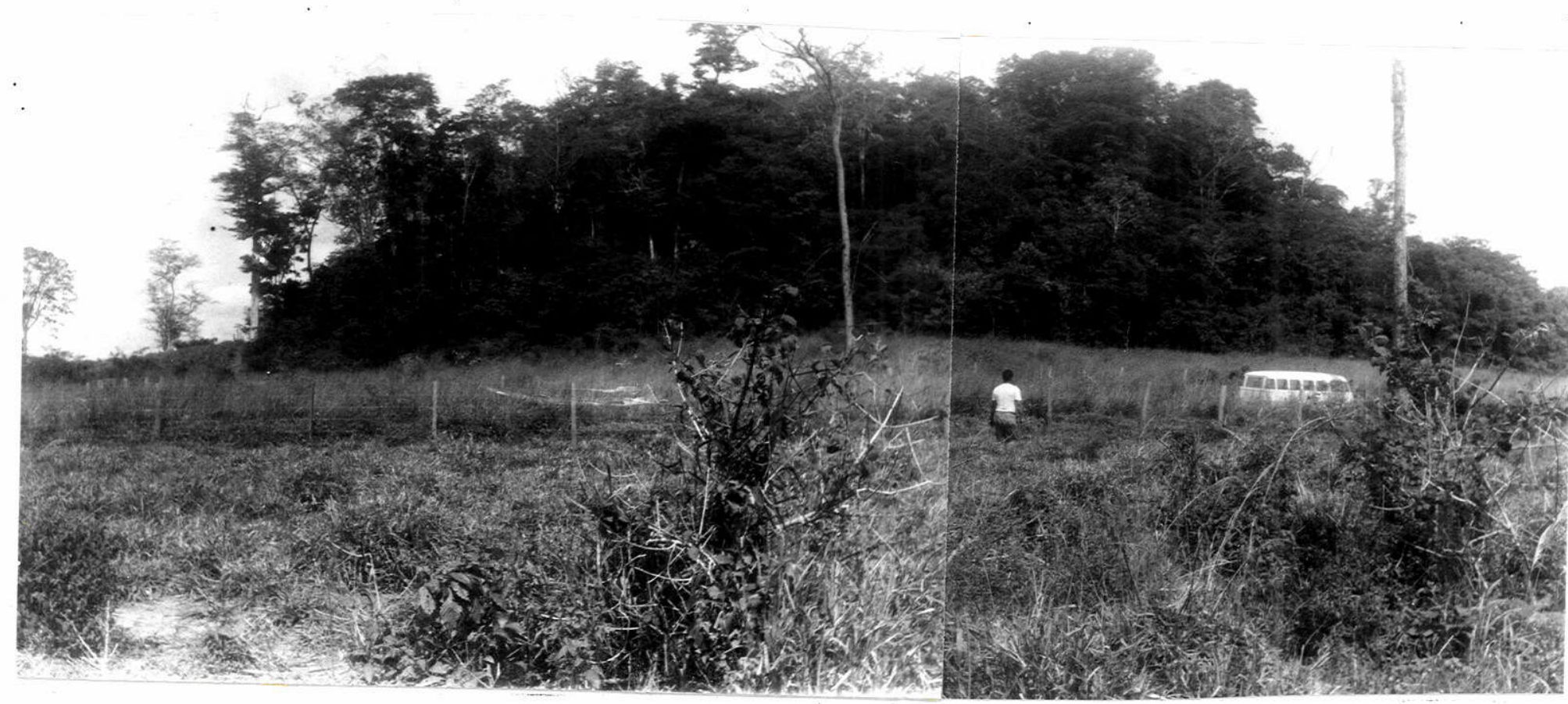

Foto 02 - Corpos intrusivos subvulcẫnicos causam pequenos morrotes isolados, com densa cobertura vegetal. No caso, trata-se de uma intrusäo subvulcânica de rochas graníticas nos terrenos arrasados da Sequêencia Vulcano-Sedimentar do Rio Alegre. 


\section{IV.3.3. Granito-Gnaisse Santa Helena}

A ocorrência dessas rochas restringe-se à parte oriental da área mapeada (Fig. 07). Regionalmente elas fazem-se representar por um maciço de dimensóes batoliticas que estende-se desde os limites da Folha JAURU, onde form definidas por SAES et al. (1984) e prolonga-se até os limites da Folha SANTA RITA, a sul. Seus contatos com a Seqüencia Vulcano-Sedimentar do Rio Alegre e Grupo Aguapeí foram interpretados como tectônicos por falha inversa e discordantes, respectivamente.

Litologicamente, apresentam-se com cores róseas, gramulação média a grossa, foliados, com biotita orientada. Sua composição mineralógica principal é constituida de quartzo, microclinio e subordinadamente plagioclásio, com pequena quantidade de minerais máficos, principalmente de biotita.

Foram observadas fases pegmatóides na forma de veios e bolsões irregulares, composicionalmente compativeis com a rocha hospedeira.

MENEZES et al. (1991) deterninaram uma idade Rb/Sr de $\pm 1,3$ $\mathrm{Ga}$, com razão inicial $\mathrm{Sr}^{87} / \mathrm{Sr}^{86}=0,714$ para rochas desse batólito em seu prolongamento na Folha PONTES E LACERDA, o que indicaria sua colocação durante o Proterozóico Médio e uma origem por refusão crustal, dado o alto valor da razão inicial. Na área deste trabalho, não foram executadas dataçôes radiométricas nos granitóides Santa Helena. 


\section{3.4. Grupo Aguapei}

Na área mapeada (Fig. 07), o Grupo Aguapeí está representado

em sua porção centro-leste, por três serras subparalelas de direção aproximada N20W. São estreitas ern sua dimensão transversal e contínuas por quase toda a área em sua dimensão longitudinal, caracterizando um relevo apalachiano, com cristas e vales alinhados, indicando um condicionamento estrutural relacionado a dobramentos e falhamentos.

Da estratigrafia típica do Grupo Aguapei, que compreende três formações (SOUZA \& HILDKED, 1980), apenas as duas unidades inferiores foram
encontradas na área mapeada.

As duas formaçốes que ocorrem na área são as denominadas de Formação Fortuna; composta por metaconglomerados oligomíticos e metarenitos ortoquartziticos; e Formaç̃a Vale da Promissño, compreendendo uma sequiência metapelitica onde se destacam litotipos tais como: filitos, ardósias e metassiltitos,

O Grupo Aguapei sobrepõe-se regionalmente, às rochas do corpo granito-gnáissico Santa Helena, às rochas da Seqüência Vulcano-Sedimentar do Rio Alegre e as do Complexo Metanórfico do Alto Guaporé através de discordância angular e erosiva. $\mathrm{Na}$ área estudada, não foi possivel verificar as relaçốes de contato observadas a nível regional.

BARROS et al. (1982) inferem idade pré-Cambriana Superior para a deposição e o metamorfismo desta unidade. $O$ autor baseia-se no fato de que, na Serra do Rio Branco (porção leste do Cráton Amazônico), o Grupo Aguapeí ocorre capeando o Embasamento Cristalino ("Complexo Xingú"), para o qual foi determinada naquela região, uma isócrona de referência $\mathrm{Rb} / \mathrm{Sr}$ de $1.400 \mathrm{Ma}$.

O Grupo Aguapeí é invadido (com contatos termometamórficos) por rochas do Grupo Rio Branco, um Complexo Intrusivo -Subvulcânico Diferenciado, incluindo os seguintes litotipos: gabros e basaltos subvulcânicos de natureza toleitica, granitos porfiros granofíricos, riodacitos, dacitos e andesitos. A isócrona de referência Rb/Sr encontrada por BARROS et al. para as rochas do Grupo Rio Branco aponta a idade de $1.130 \pm 71 \mathrm{Ma}$ e razão inicial $\mathrm{Sr}^{87} / \mathrm{Sr}^{86}=0,708$. Entretanto, MORAES \& MAKHOUL (1986) e MENEZES et al. (1991) admitem uma idade mais antiga (Mesoproterozóica) para o Grupo Aguapeí, com base em observações e correlações geológicas, posição esta, defendida neste trabalho. 


\section{IV.3.7. Formaçăo Guaporé}

Esta unidade (Fig. 07) é formada por sedimentos inconsolidados, areias, siltes, argilas, demais depósitos elúvio-coluvionares e aluvionares existentes na área mapeada, incluindo tambén os produtos de intemperismo lateritico superficiais, de espessuras variáveis (oscilan de dezenas a centenas de metros) de todos os litotipos pré-Cambrianos. Esses sedimentos depositaram-se sobre as litologias mais antigas, ou formaram-se por intemperismo "in situ" destas, mascarando os vestígios de suas ocorrências, dissinulando afloramentos, principalmente das rochas vulcânicas máficas, xistos máficos: metapelitos da Sequência Vulcano-Sedimentar do Rio Alegre. 
Fig 07 ESBOÇO GEOLÓGICO DA REGIÃO DO RIO ALEGRE. -MT.

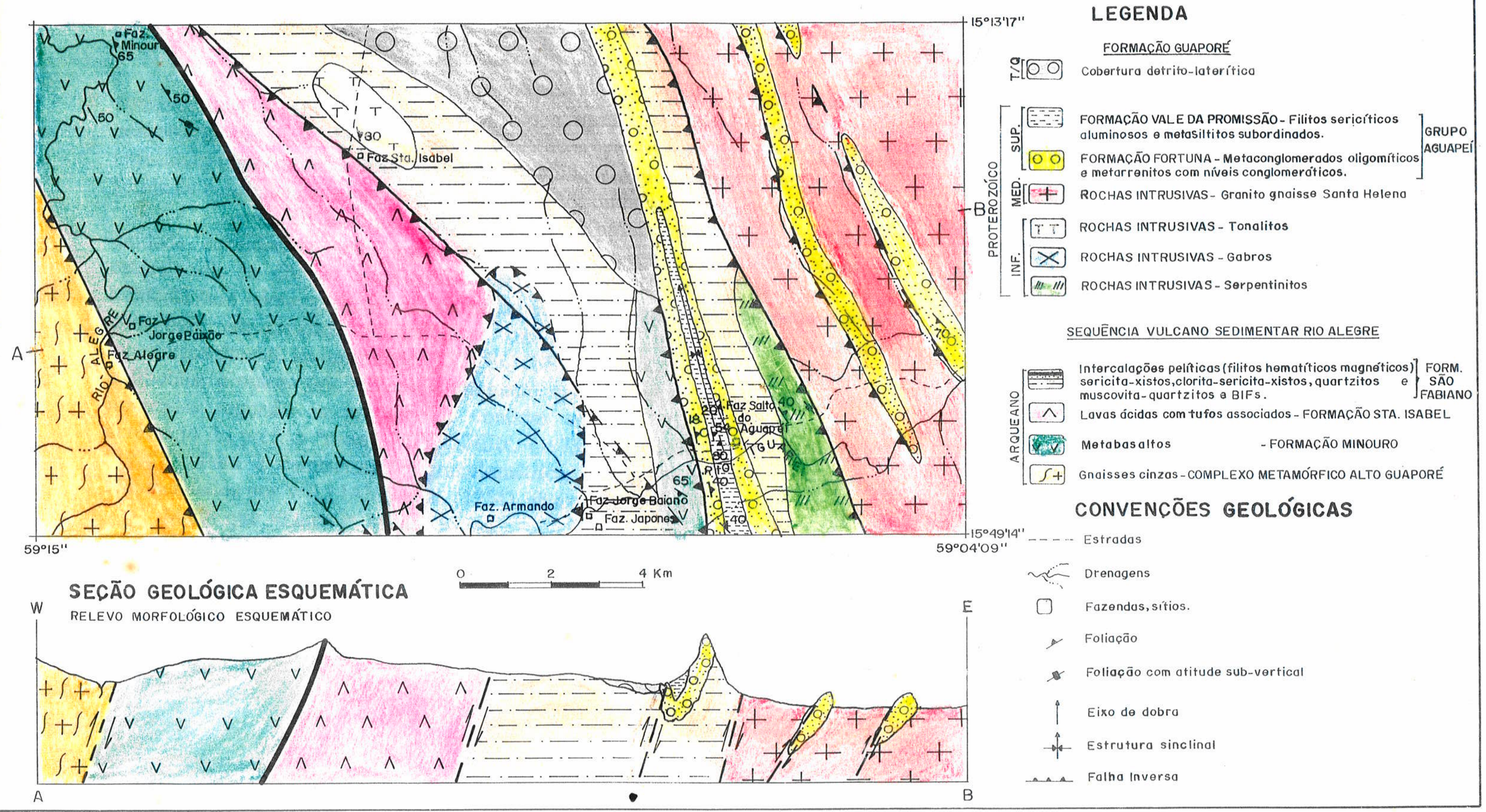




\section{CAPÍtulo $V$}

\section{PETROGRATIA}

Os estudos petrográticos apresentados neste capitulo compreendem a descriçăo sistemática das propriedades estruturais/texturais e composicionais dos diversos tipos litológicos presentes na área mapeada, enfocando também a sua distribuição e variabilidade regional bem cono o tipo e a forma de ocorrencina dos corpos geológicos correspondentes.

Os litotipos estão descritos em orden cronológica, on seja, da unidade considerada mais antiga para a mais recente, em observancia ao estabelecido na divisão estratigráfica proposta neste trabalho (Fig. 06). Já a nomenclatura adotada obedeceu aos princípios de classificação de rochas ígneas com base em critérios mineralógicos (modais e/ou normativos) e texturais, internacionaimente recomendados (STRECKEISEN, 1976) para rochas granitóides, anfibolitos e outros ortoderivados, enquanto que as rochas paraderivadas foram nomeadas segundo as proposiçöes contidas em PETTIJOHN (1975) com o actéscimo do prefixo "meta", MIYASHIRO (1973), WINKLER (1977) e TURNER (1978). Para a caracterização granulométrica, foram obedecidos os critérios
recomendados por WILLIAMS et al. (1954), abaixo transcritas:

Maior que $30 \mathrm{~mm}=$ Muito Grossa

Entre $5 \mathrm{e} 30 \mathrm{~mm}=$ Grossa

Entre 1 e $5 \mathrm{~mm}=$ Média

Menor que 1 mm = Fina 


\section{V.1. Complexo Metamórfico do Alto Guaporé}

As rochas pertencentes à esta unidade são de oconência restrita à parte ocidental da área mapeada, apresentando-se tão somente sob a forma de matacões dispersos por entre a vegetação.

Destacam-se homblenda-biotita gnaisses e rochas cataclásticas deles derivadas, dentre os litotipos mais representativos. A granulação varia entre fina a média, predominando os tipos equigranulares e sub-equigranulares, leuco a mesocráticos, mostrando composição predominantemente tonalítica. Sua foliação é nitida dada pela orientaçăo e concentração de minerais máficos e félsicos em bandas discretas, causadas por segregações/diferenciações dinamometamórficas.

Em afloranentos localizados nas circunvizinhanças da área, como os da sede da Fazenda Alvorada, distando aproximadamente $5 \mathrm{~km}$ a sul da área mapeada, podem ser observadas ocorrências de enclaves de anfibolitos e diques máficos em gnaisses intrusivos tonaliticos, investigadas por PINHO (1990).

De modo geral, as rochas dessa unidade possuem cor cinzaclara, foliação proeminente conferida pelo arranjo sub-paralelo das biotitas e ocorrência subordinada de homblenda. Sua matriz é composta essencialmente de plagioclásio (andesina) e quartzo. Os minerais secundários mais comuns são muscovita e epidoto e os acessótios, zircão, titanita, apatita e opacos.

Nos parcos "afloramentos" (matacões) dessa unidade, predominam as estruturas bandadas, regulares, frequentemente possuindo concentrações de biotita sob a forma de "schlieren"; sugerindo tratar-se de restitos e/ou segregaçóes de fusão/anatexia. A foto 03 mostra o modo de ocorrência dos gnaisses do Complexo Metamórfico do Alto Guaporé.

Ao microscópio, a rocha exibe textura nematoblástica, dada pelo alinhamento dos cristais prismáticos-aciculares de hornblenda, com variações à textura lepidoblástica em tipos mais ricos em biotita, paralelamente orientados.

A homblenda $( \pm 8 \%)$ tem cor verde a amarelo-esverdeada, ocorre em grãos xenoblásticos, estirados, com reações retrometamórficas de transformação para biotita e/ou clorita + epidoto.

O quartzo ( $\pm 33 \%)$ apresenta-se como grãos xenoblásticos, com extinção ondulante e evidências texturais de recuperação como formação de șubgrãos e recristalização em individuos poligonais, sem extinção ondulante.

A andesina ( $\pm 31 \%$ ) apresenta-se comumente com formas xenoblásticas, com reações de sanssuritização gerando epidoto + mica branca + 

carbonato. Podem ocorrer grãos deformados, apresentando lamelas de geninação
polissintética, onduladas e fragmentadas.

A biotita $( \pm 18 \%$ ) tem cor marron, pleocroismo marron e apresenta indícios de deformação com o dobramento de suas palhetas e extinção
ondulante.

A granada ( \pm 3\%), nem sempre presente, caracteriza-se por grãos xenoblásticos, fraturados, com inclusões de quartzo, biotita e cristais menores de hornblenda. Pode apresentar evidencias de retrometamorfismo (cloritização).

Os minerais secundários estão representados pela seguinte associação: carbonato, epidoto, clorita e sericita oriundos de reaçôes de saussuritização dos plagioclásios e retrometamorfismo dos minerais máficos. Os acessórios como apatita e titanita geralmente ocorrem sob a forma de inclusões.

As fotonicrografias 01 e 02 mostram a caracteristica textural mais marcante nessas rochas que é o bandamento composicional.

Os resultados obtidos para o conjunto de gnaisses do Complexo Metamórfico do Alto Guaporé são preliminares e anda escassos, em função das condiçóes regionais de afloramentos, muito raros e restritos que não permitiram, na escala deste trabalho, levantamentos e amostragens mais detalhadas. Ainda assim, notaram-se dois grupos distintos de gnaisses: o primeiro de rochas com granada (perahminosas) e o segundo, isento de granada, com hormblenda substancial (metaluminosas), que indicam a heterogeneidade do Complexo Metamórfico do Alto Guaporé. Nessas condiçôes, é prematuro aventar considerą̧óes petrogenéticas mais detalhadas. Entretanto é possivel interpretar que um ou mais eventos metamórficos de médio a alto grau afetando rochas ígneas e/ou seus produtos de alteração/ intemperismo, foram responsáveis pela constituição primária polimetamórfica deste Complexo, ou trata-se de sequëencia oriunda de associaçäo cálcio-alcalina de alto $\mathrm{Al}$, onde é normal a ocorrência de pequenas quantidades de granada em sua constituição mineralógica.

As evidências de retrometamorfismo devem ser associadas ao metamorfismo de baixo grau em relação à evolução da Seqüência VulcanoSedimentar do Rio Alegre elou à evolução metamórfica proterozóica do Grupo
Aguapeí. 


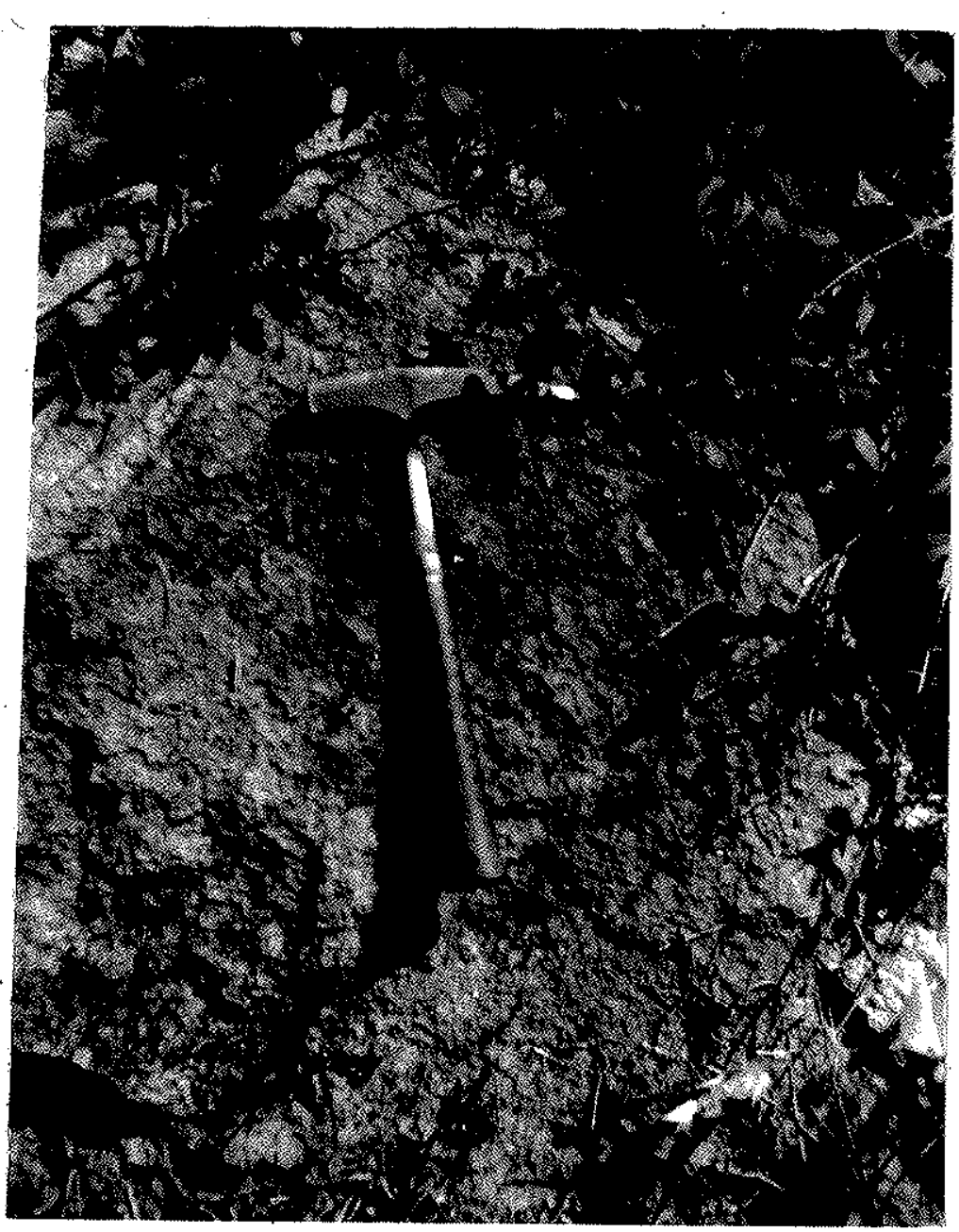

Foto 03 - Aspecto típico de "afloramento em matacoes" de rochas granitognáissicas do Complexo Metamórfico do Alto Guaporé. Fica evidente também a precariedade dos afloramentos naturais deste tipo, na área estudada. 


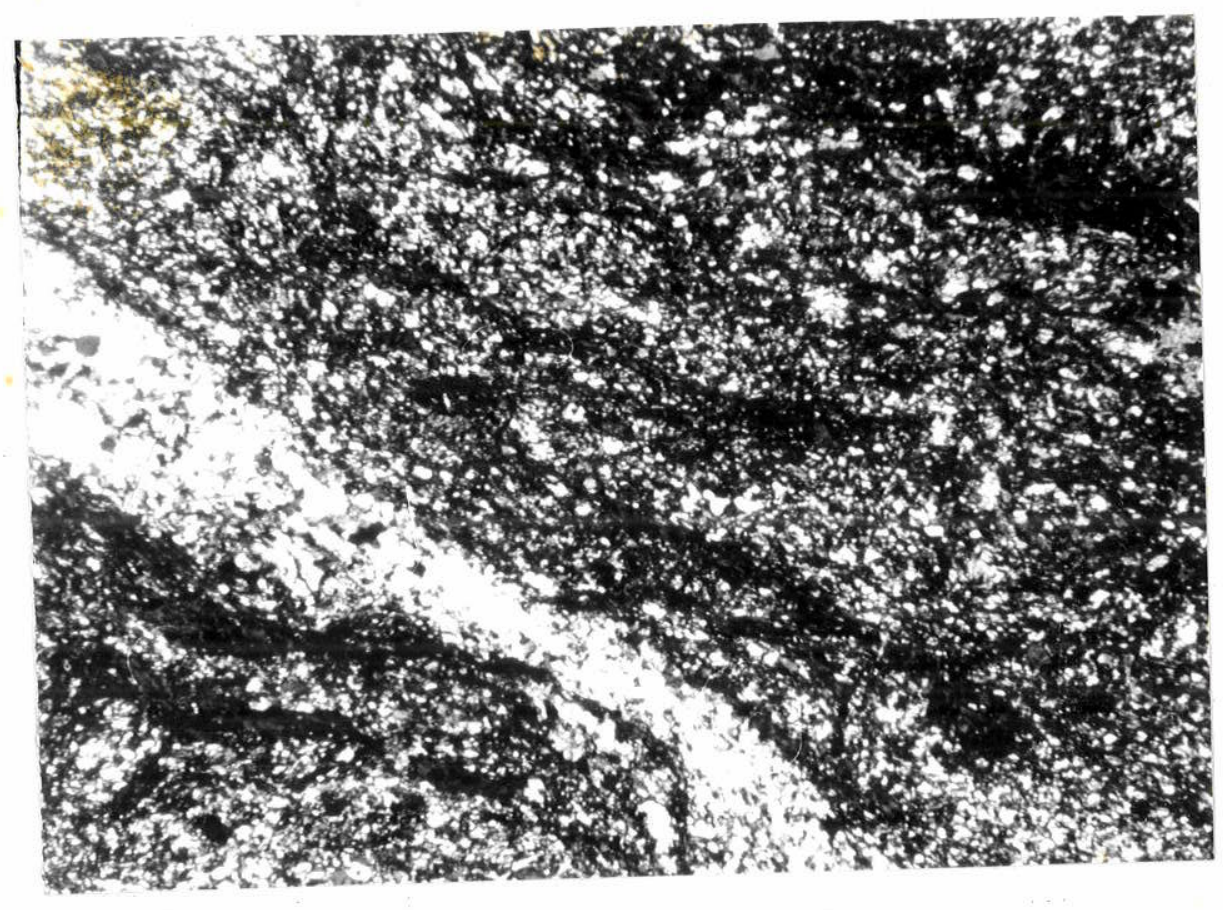

Fotomicrografia 01 - Seção no 79, aumento 32X/NX (polarizadores cruzados) Hornblenda Gnaisse do Complexo Metamórfico do Alto Guaporé. O Bandamento composicional (de transposição) é marcante, com ondulações suaves.

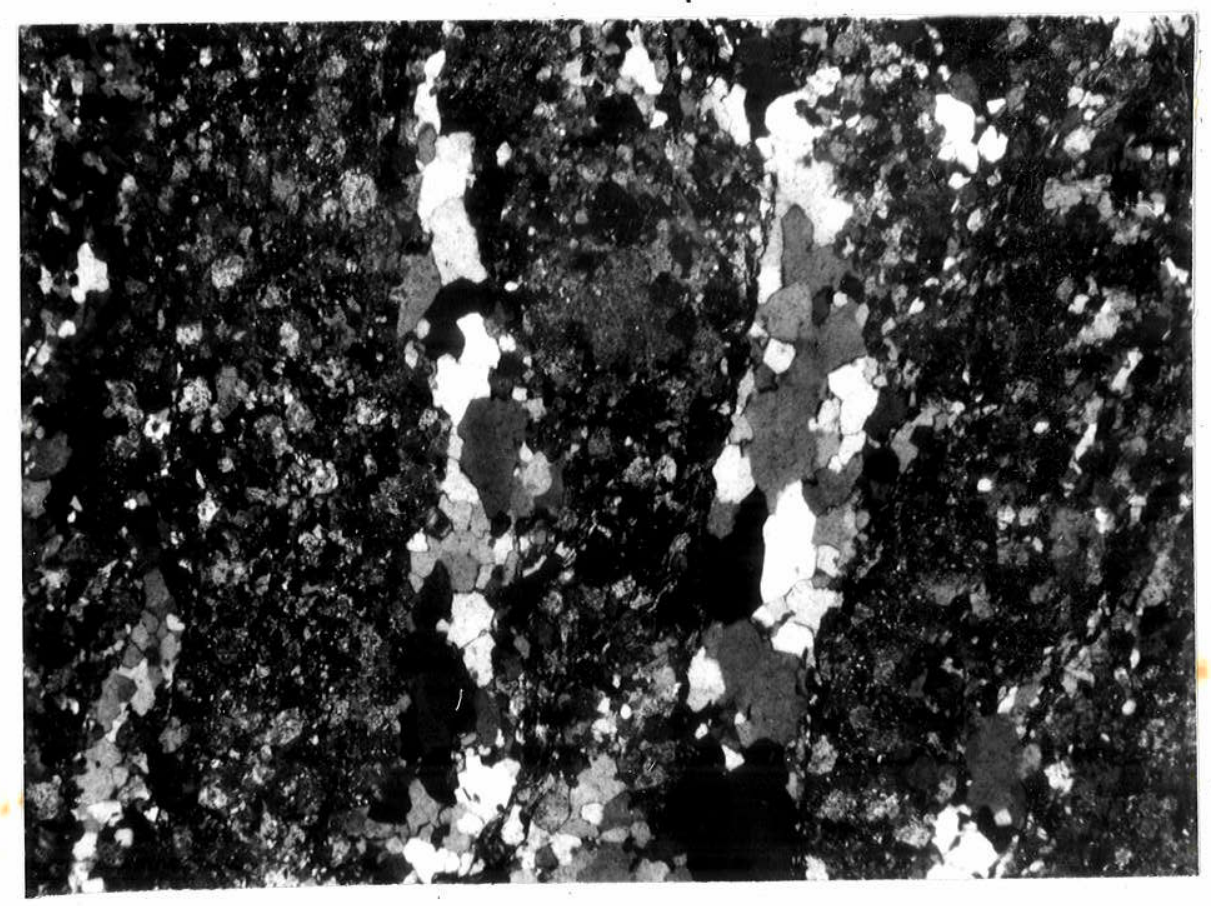

Fotomicrografia 02 - Seção no 79, aumento 32X/NX - Biotita Gnaisse bandado. Os leitos quartzosos mostram feições de recristalizaçăo de quartzo. 


\section{V.2. Seqüêncin Vulcano-Sedimentar do Rio Alegre e Intrusivas Associadas}

Esta unidade distribui-se em toda a faixa central da área mapeada e compreende litotipos vulcânicos variando desde basaltos até tufos ácidos, associados à rochas sedimentares clásticas e químicas. Para efeito estratigráfico, esse conjunto foi subdividido em três unidades, de acordo con suas caracteristicas litológicas principais, denominadas da base para o topo de Formação Minouro, Formação Santa Isabel e Formação São Fabiano.

$\mathrm{Na}$ unidade basal (Formação Minouro), os litotipos mais proeminentes são representados por metabasaltos com gramulação fina, associados a restos de metassedimentos químicos (cherts e formações ferríferas bandadas) e se estendem por toda a área de ocorrência da Sequência Vulcano-Sedimentar do Rio Alegre.

As rochas mais representativas da Formação Santa Isabel compóem-se de litotipos vulcânicos e piroclásticos de natureza riolitico-dacítica, e são de ocorrência mais restrita. Estendem-se desde a Fazenda Santa Isabel até o limite sul da área mapeada.

A Formação São Fabiano está representada por intercalações de metassedimentos clásticos e químicos (xistos sericíticos e xistos com quartzo, hematitico-magnetiticos), metacherts, formaçôes ferriferas bandadas e metavulcanoclásticas ocorrendo nas partes central e oriental da área. Todas as rochas da Sequência Vulcano-Sedimentar do Rio Alegre, incluindo as rochas intrusivas, são caracterizadas de um modo geral por uma foliação principal, com direção preferencial em torno de $\mathrm{N} 20 \mathrm{~W} /$ subvertical e duas secundárias, representadas por forte foliação de transposição causada na deformação principal $(\mathrm{Dn}+1)$, subparalela à foliação pincipal e clivagem de crenulação com forte redobramento da foliação principal $(\mathrm{Dn}+2)$. Estas fases de deformação podem ser observadas na foto $07 \mathrm{e}$ fotomicrografias $08 \mathrm{e} 09$. 


\section{V.2.1. Metabasaltos}

Estas rochas, que constituem a Formação Minouro, englobam litotipos efusivos melanocráticos a mesocráticos, com granulação fina, equigranulares, estrutura foliada e ainda rochas intrusivas subvulcânicas da mesma faixa composicional, com textura e granulação mais grossa.

A foto 04 ilustra uma situação de afloramento da Formação Minouro, na margem do rio Aguapeí e as fotos 05 e 06 mostram um dique de diabásio intrusivo na Formação São Fabiano, analisado conjuntamente com as rochas da Formação Minouro.

Ao microscópio, os metabasaltos exibem texturas granonematoblásticas, com orientação incipiente de cristais de hornblenda e raramente de biotita. Os representantes desses litotipos encontrados na área, quase que invariavelmente apresentam poucas modificações estruturais pós-cristalização, com minerais metamórficos substituindo os magmáticos sem obliteração da textura pretérita, nas quais é possivel distingüir texturas porfiriticas (fotomicrografias $03 \mathrm{e}$ 04) e reliquias de arranjos sub-ofiticos (fotomicrografia 05).

A mineralogia desses litotipos está sintetizada na Tabela 01 , sendo que as características mineralógicas são descritas a seguir:

Os plagioclásios parcialmente saussuritizados ocorrem principalmente com composiç̃̃o da andesina, podendo aparecer o oligoclásio subordinado (composiçōes também estimadas pelo método Michel-Levy). Geralmente os grãos apresentam contornos irregulares, com genuinação polissintética (lei da albita e raramente Carlsbad). As inclusões sólidas mais freqüentemente encontradas nesses minerais ș̃o o epidoto e a hornblenda, sendo raras as inclusões de apatita.

Os anfibólios são os constituintes principais e ocorrem frequientemente sob a forma de homblenda/tschermaquita e ocasionalmente como tremolita/actinolita. 


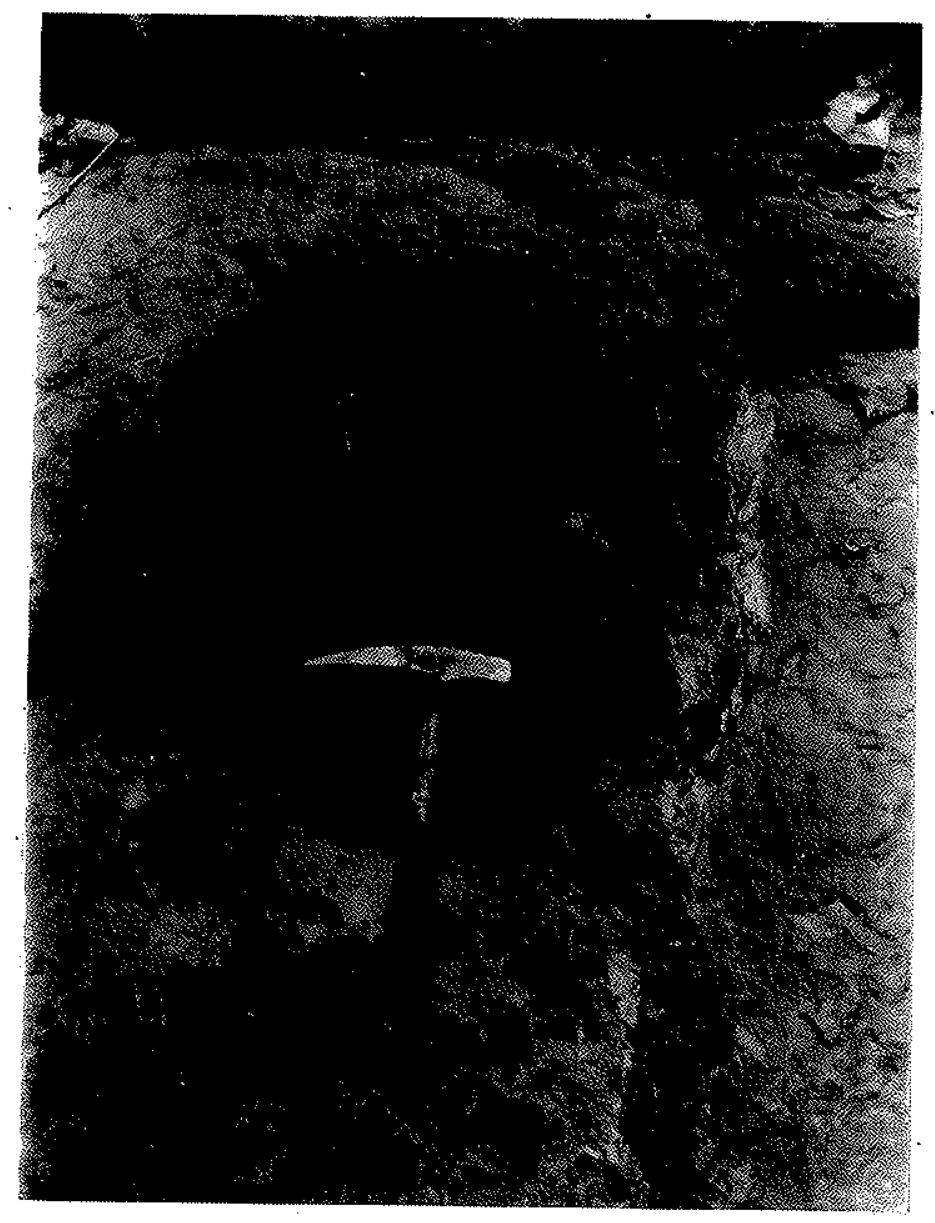

Foto 04 - Afloramento no 122 (Figura 05) mostrando metabasalto da Formação Minouro, às margens do Rio Aguapeí, próximo à "Fazenda do Japonês". As rochas encontram-se muito fraturadas e fortemente intemperisadas. 


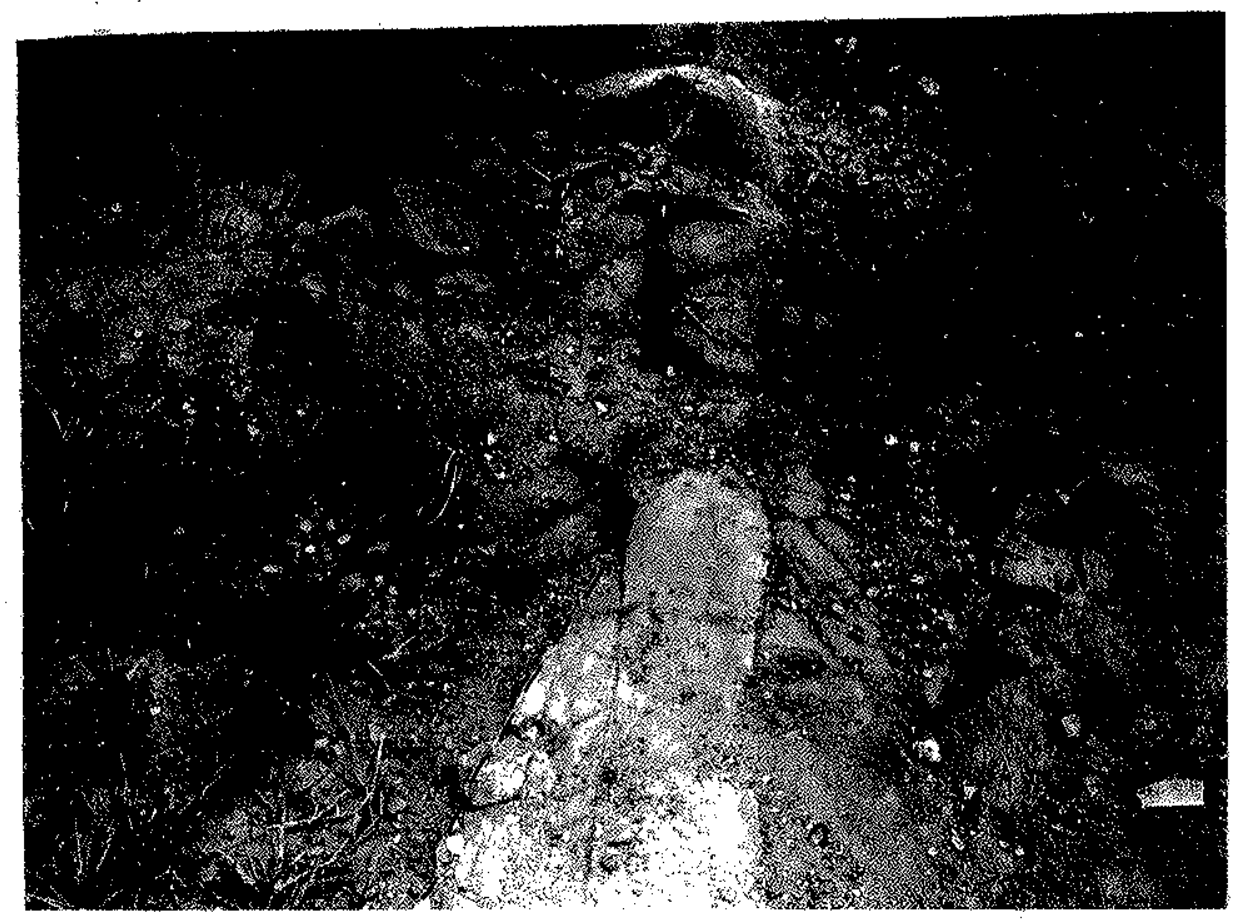

Foto 05 - Dique metabásico cortando os metassedimentos da Formação São Fabiano, ocorrendo ina margem do Rio Aguapel (Fazenda do Japonéšs), Com até $0,50 \mathrm{~m}$ de espessura (afloramento no 22 , Figura 05).

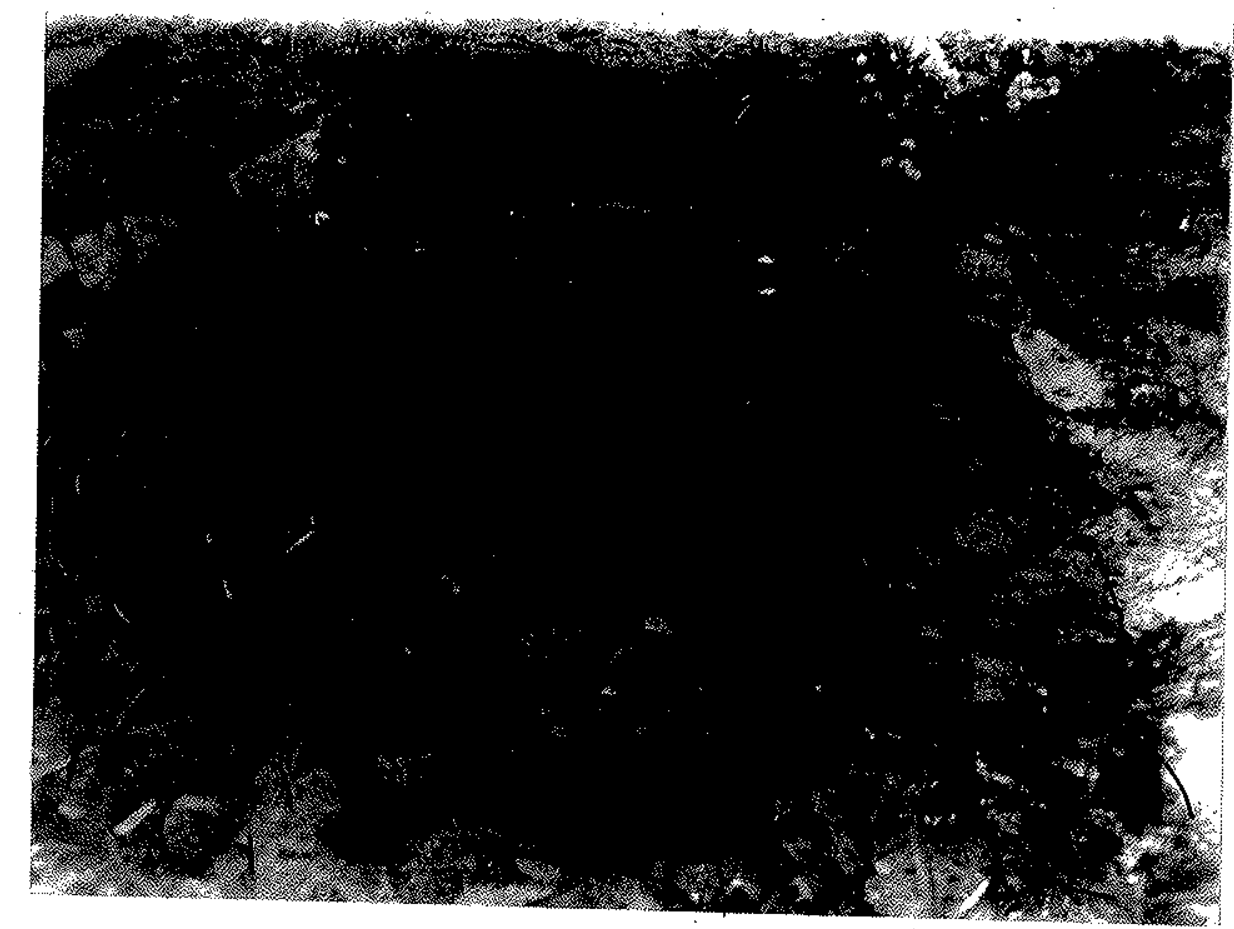

Foto 06 - Outro detalhe do afloramento retratado na foto 05 , mostrando restos de intemperismo da rocha metabásica, com estruturas de esfoliação esferoidal. 
A hornblenda/tschermaquita tem cor verde, com pleocroismo esverdeado e média birrefringência enquanto que a tremolita/actinolita é o anfibólio incolor, com fraco pleocroísmo esverdeado e alta birrefringência. Os anfibólios formam grãos subidioblásticos a xenoblásticos comumente agregados; substituindo os minerais máficos primários, principalmente os clinopiroxênios. As amostras 27 e 25 evidenciam respectivamente textura reliquiar porfiritica e sub-ofitica (fotomicrografias 03 e 05 ).

O quartzo ocorre como constituinte subordinado, com porcentagens de até $8 \%$. Nos metabasaltos do Rio Alegre, o lugar-comum é a sua ocorrência como produto metamórfico em pequenas quantidades, ou mesmo a sua ausência. Os grãos são anédricos e freqüentemente agrupam-se em leitos e ocorrem como inclusốes globulares nos anfibólios.

Epidoto (incluindo zoisita/clinozoisita), carbonatos, sericita e clorita resultantes de reações retrometamórficas oriundas das transformações de plagioclásio, clinopiroxênio e anfibólios.

Opacos, zircão, titanita e apatita são os minerais acessórios mais comuns, sendo que a biotita em apenas duas seçôes (38a e 115). 


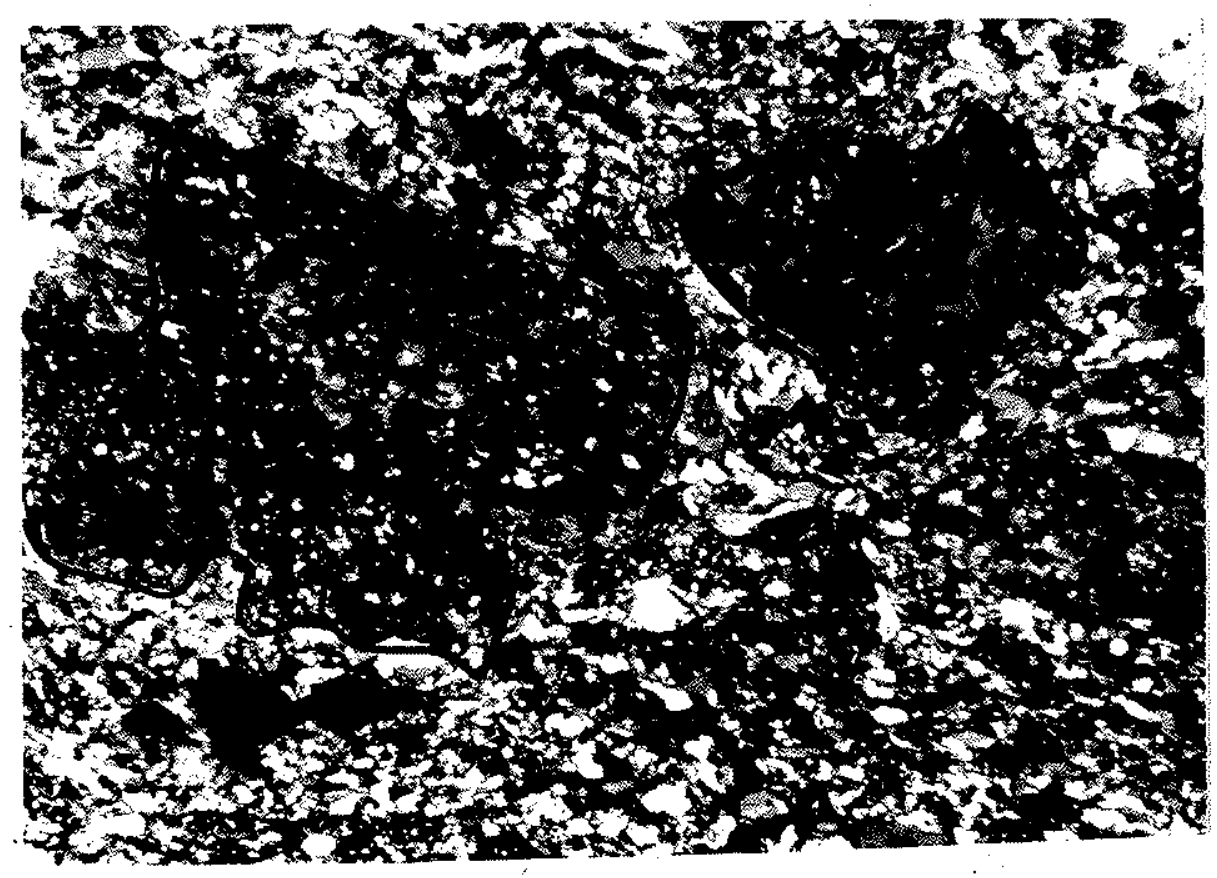

Fotomicrografia 03 - Seção no 27, aumento 32X/NX - Metabasalto mostrando textura porfirítica, onde as relíquíss de fenocristais de plagioclásio estaso saussuritizadas inseridas em uma matriz fina. 


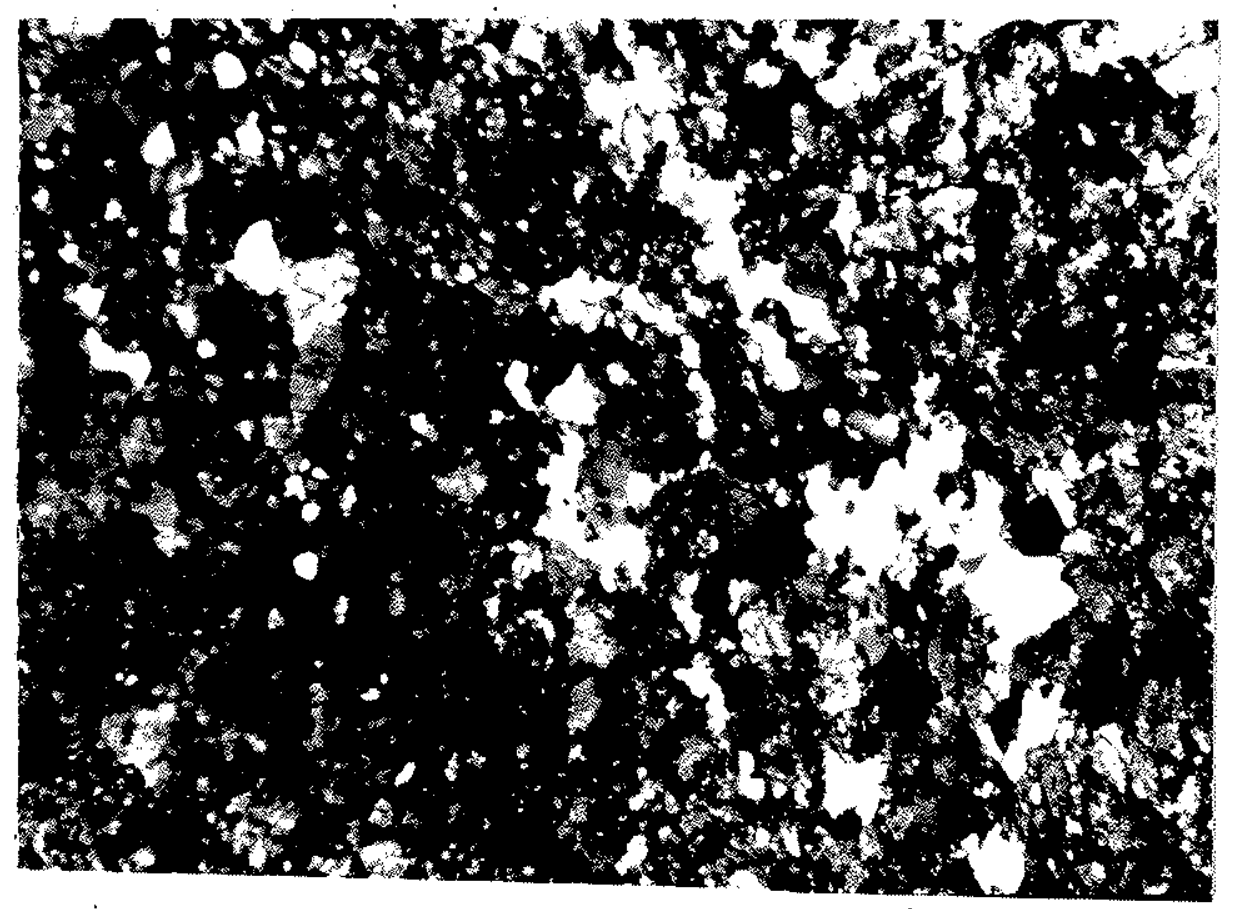
foliação incipiente. Grấos idiomórficos de titanita são destaque.

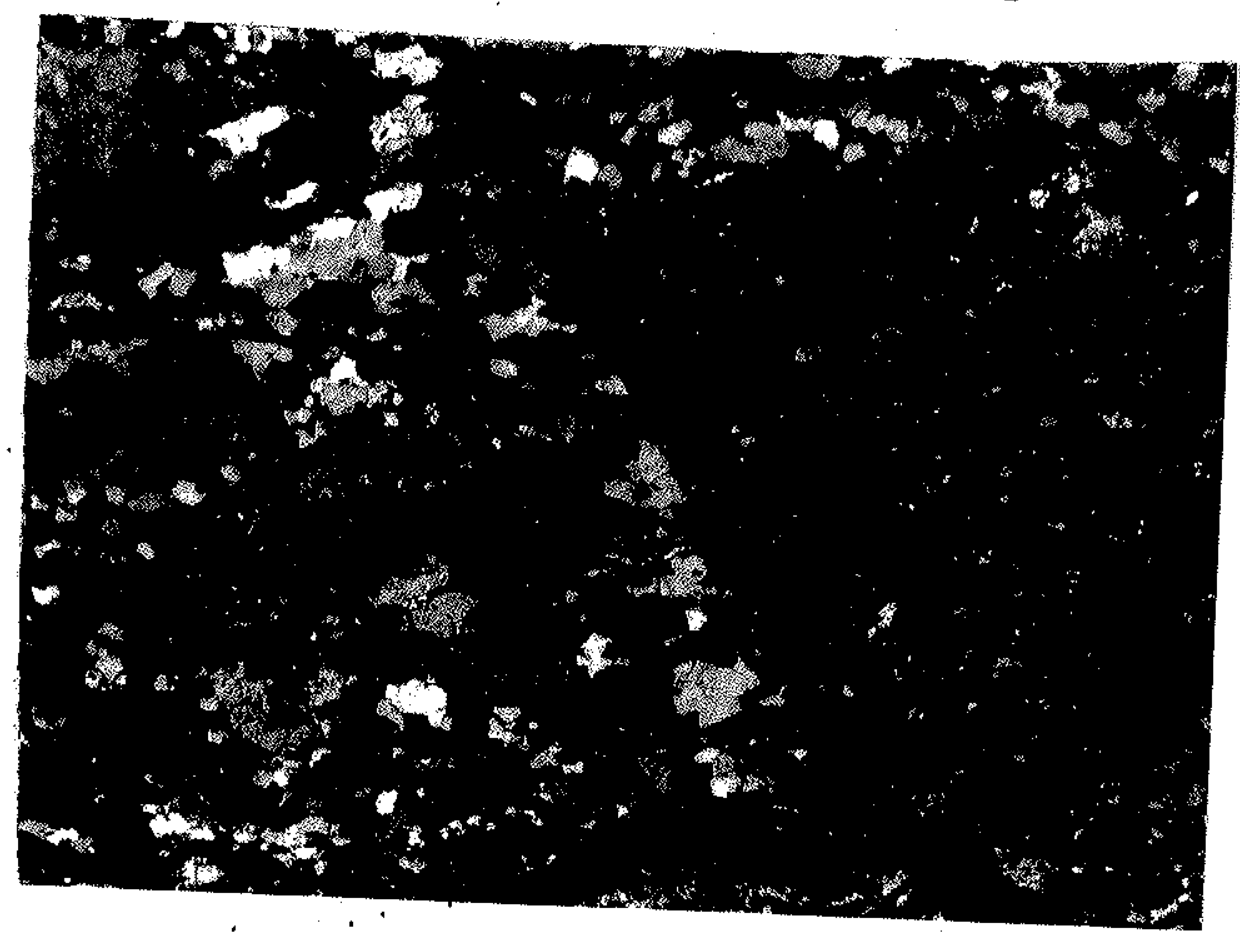

Fotomicrografia 05 - Seção no 115, aumento $32 \times / N P$ (polarizadores paralelos), mostra metabasalto com textura porfiritica, com fraturas preenchidas por mineral
secundário (epidoto). 
TABELA 81 - Análises Modais de Retabasitos (\% Bol.)

\begin{tabular}{|c|c|c|c|c|c|c|c|c|c|c|c|c|c|}
\hline AMOSTRAS & $15^{* *}$ & $15 a$ & 153 & $22^{3}$ & 25 & $34^{\text {解 }}$ & $3 A_{a}$ & 393 & 192 & 1028 & 115 & 12 & 122 \\
\hline fl agioolásio & 25,9 & 15,3 & 14,2 & 25,1 & 35,3 & 22,4 & 28,3 & 33,2 & 48,8 & 54,5 & 15,8 & 13,3 & 29,1 \\
\hline Horntlenta & - & - & - & - & 48,8 & 28,3 & 42,1 & 23,3 & - & 36,3 & - & 66,8 & tr \\
\hline Bictita & - & - & - & - & - & - & - & 2,5 & - & - & tr & - & tr \\
\hline Epidato" & 49,1 & 12,3 & 23,2 & 18,3 & 3,3 & 3,8 & 3,5 & 11,3 & 32,1 & tr & 45,2 & 31,1 & 46,9 \\
\hline Quartzo & 3,8 & ir & 12,6 & - & 5,8 & 5,8 & 3,6 & 18,1 & 4,2 & 9,1 & - & 3,8 & 14,8 \\
\hline $9 p a c o s$ & 2,8 & $t_{r}$ & - & $t r$ & tr & $t r$ & tr & tr & $t s$ & to & tr & tr & $t_{r}$ \\
\hline Titanita & - & - & - & tr & tr & - & 8,4 & tr & tr & in & tr & tr & $t_{r}$ \\
\hline Apatita & - & - & - & - & tr & - & - & tr. & - & tr & - & th & tr \\
\hline zircão & - & - & - & - & - & - & - & - & - & $t r$ & tr & $i r$ & - \\
\hline Carbonatos & - & - & - & 15,6 & - & 15,1 & - & 2,8 & tr & $t r$ & - & tr & tr. \\
\hline Sericita & - & 18,2 & - & 5,4 & 22,3 & 26,3 & 18,8 & $t$ & - & ts & - & $2 n$ & to \\
\hline Clorita & - & - & - & - & t. & $-3,8$ & 3,4 & $\{5,2$ & - & - & - & - & - \\
\hline Trensotinolita & 18,2 & 69,3 & $58, ?$ & 45,1 & - & - & - & - & $22, ?$ & - & 33,8 & - & - \\
\hline $20 \mathrm{i} / \mathrm{Clinozoisita}$ & 1,3 & - & $t_{r}$ & tr & 1,2 & 8,8 & 4,1 & - & - & - & - & - & - \\
\hline leucoxenio & - & - & - & - & tr & - & - & - & - & - & - & - & - \\
\hline
\end{tabular}

Legenda: * Ninerais de Altereçã

** Sorhas Fortemente Eridutizadas

\# Diques Sutwulcầicus

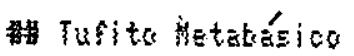




\section{V.2.2. Metadacitos, Meta-riolitos e Metapiroclástica}

Os litotipos efusivos mesocráticos que ocorrem com estas composições foram informalmente designados neste trabalho como Formaçño Santa Isabel, por ocuparem toda a parte central da área mapeada tendo as suas melhores exposiçôes nas proxinidades da Fazerida Homônima.

Os metadacitos e metariolitos são rochas de cores variadas (cinza-clara a verde -escura), estrutura isótropa, às vezes denotando foliação incipiente. Freqüentemente apresentam halos de intemperismo proeminente nos blocos e matacões expostos.

As rochas piroclásticas são caracterizadas por uma granulação fina a muito fina, sendo que a amostra no 11 evidencia fragmentos lapili imersos em matriz microcristalina, parcialmente substituida por carbonatos (Fotomicrografia
06 e 07).

Ao microscópio, a amostra de rocha pirocléstica exibe textura granoblástica; enquanto que nas efusivas ácidas, podem ocorrer tipos blastoporfiríticos (amostra no 38 ). A moda dessas rochas está sintetizada na Tabela 02 .

Nessas rochas, o microclinio e o ortoclásio são os constituintes mais importantes. Seus grãos são freqüentemente subédricos, de contornos irregulares, incolores, relevo baixo e birrefringência de $1^{\text {a }}$ ordem, apresentam geminação Carlsbad (ortoclásio) e Periclínio-Albita (microclínio).

O quartzo apresenta grãos anédricos, incolores, de contomos irregulares, com birrefringência de 1a ordem e freqüentemente extinção ondulante.

O plagioclásio ocorre subordinadamente em relação aos minerais anteriores e apresenta grãos subédricos com evidências de alteração póscristalização. Esses minerais podem estar levemente alterados ou intensamente saussuritizados gerando como subprodutos epidoto e finas palhetas de mica branca. Composicionalmente, os grãos foram estimados como sendo do tipo
oligoclásio.

Clorita epidoto e sericita são os minerais de alteração mais
orrem nessas. rochas. Biotita marron (ocorre em uma amostra) apresenta processos de cloritização.

Os minerais acessórios presentes nessas rochas são: titanita, diopsídio (relíquias), zircão, apatita e opacos. 


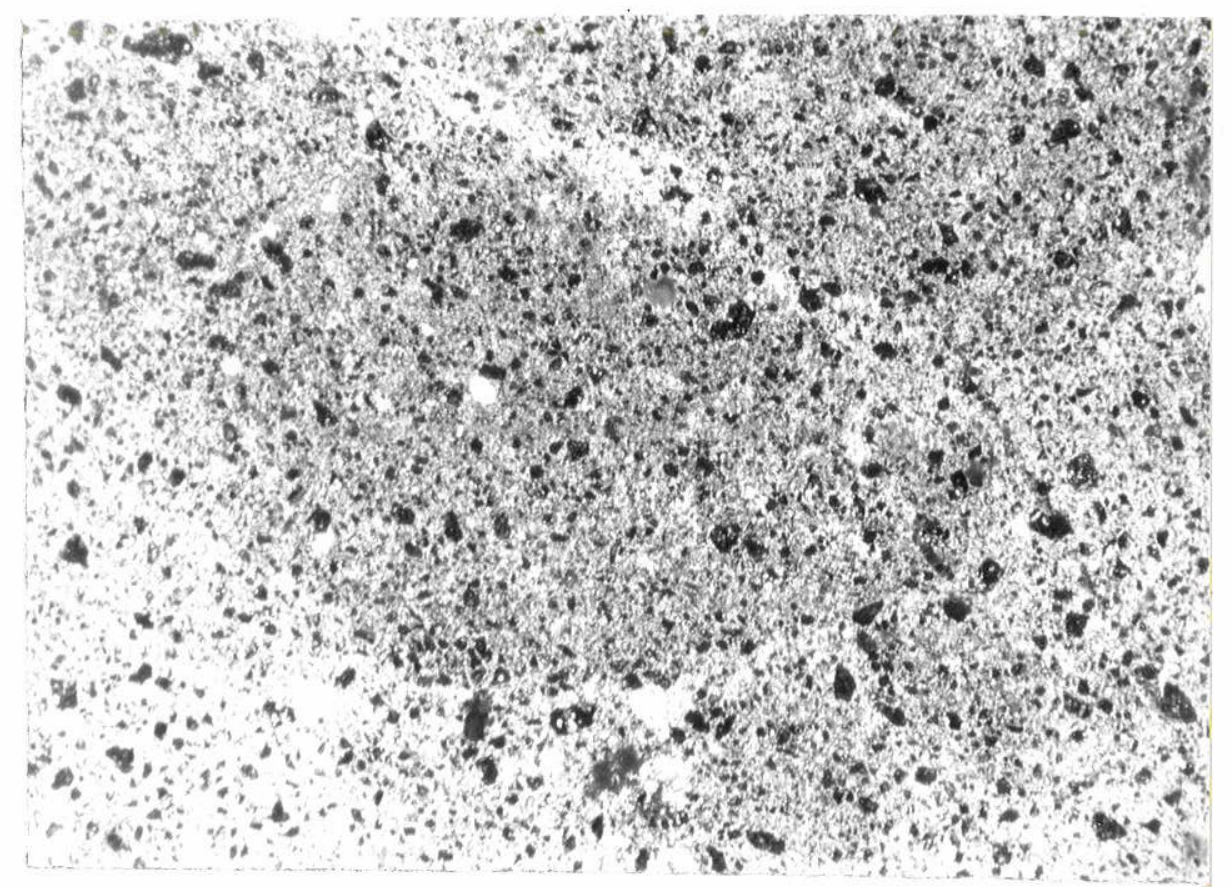

Fotomicrografía 06 - Seção no 11, aumento 32X/NP - Metatufo lítico com fragmentos lapili. A matriz microcristalina é predominantemente constituáda por calcita secundária.

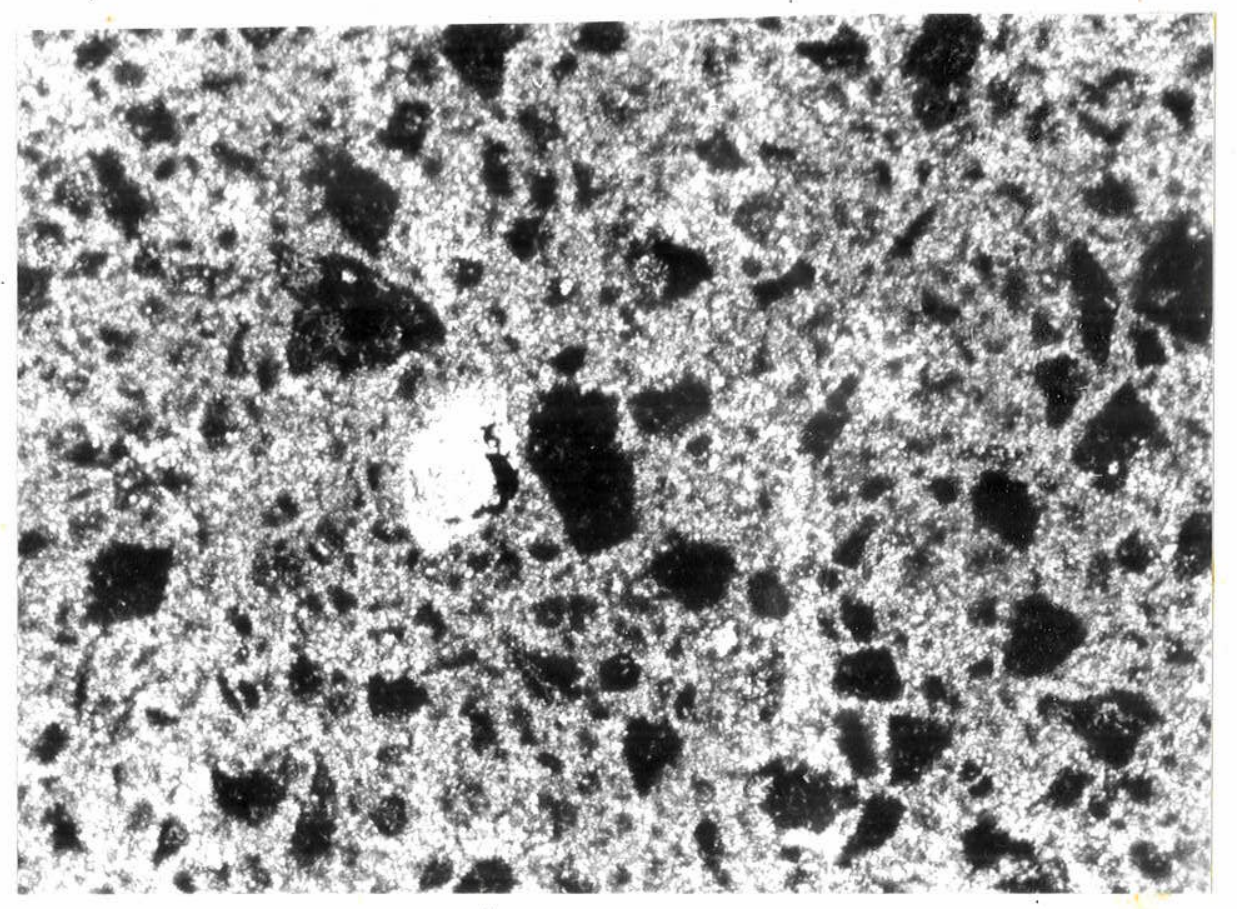

Fotomicrografia 07 - Seção no 11, aumento 200X/NX - Detalhe evidenciando a angulosidade dos fragmentos criptocristalinos não identificados (eventualmente vidros vulcânicos devitrificados) na matriz fina, carbonatizada, com foliação incipiente. 
TAaEla a2 - Análises Modris de Metaunfanitos Ácidos e Rocha Metapirnclástica (\% Vol.)

\begin{tabular}{|c|c|c|c|c|c|c|c|c|c|}
\hline AMAOSTRAS & 96 & $.11^{*}$ & 12 & 20 & 29 & 37 & 38 & 107 & 124 \\
\hline MPlagioolásio & - & 1,3 & 44,5 & 12,3 & 28,5 & 5,8 & 15,6 & 35,0 & 32,8 \\
\hline (Buartzo & 25,2 & 13,5 & 33,2 & 31,4 & 35,4 & 23,1 & $1 a, 1$ & 38,9 & 33,1 \\
\hline Hioroclínio & 17,1 & - & 3,0 & 25,3 & $30,3$. & 35,3 & 21,2 & 15,7 & 13,4 \\
\hline piatita & - & - & - & - & - & - & 2,3 & - & - \\
\hline$\| F$ ragth. de Rochis & - & 22,5 & - & - & - & - & - & - & - \\
\hline Clarita & 14,3 & - & 13,8 & 6,3 & 2,3 & $18 ; 3$ & 13,1 & 7,6 & 2,3 \\
\hline$\|$ Epidato & 22,7 & 1,8 & - & 8,5 & tr. & 8,4 & 16,3 & - & - \\
\hline Sericita" & - & - & 3,1 & 15,2 & 3,7 & 13,3 & 5,0 & 8,1 & 8,5 \\
\hline Hopacos & 1,8 & 8,5 & 1,5 & - & tr. & - & tr. & 1,7 & tr \\
\hline Carbonatos & - & 56,2 & 8,5, & - & - & tr & 2,1 & 8,5 & 5,3 \\
\hline ritanita & - & - & - & - & - & $t r$ & $\operatorname{tr}$ & - & - \\
\hline Apatitia & - & 1,8 & 0,5 & - & - & - & - & - & - \\
\hline Matriz Criptocrist. & 20,7 & $\because$ & - & - & - & - & - & - & - \\
\hline
\end{tabular}

Legerda: * Ninerais de Alterayäo

* Roctia Piraciástica 


\section{V.2.3. Xistos, Metacherts e Formaçöes Ferriferas Bandadas}

As rochas pertencentes à Formação São Fabiano, cujos litotipos mais importantes estão agrupados em epígrafe, apresentam cores variadas, granulą̧̃̃o fina, estrutura xistosa (bandada nas BIFs - Fotos 07 e 08). Ao microscópio os xistos podem exibir texturas lepidoblásticas e freqüentemente clivagem de crenulą̧ão (Fotomicrografia 08).

A análise das paragêneses minerais (Tabela 03) revela um metamorfismo de fácies xistos verdes baixo, correspondente à zona da clorita de BARROW (1912).

Nos xistos, o quartzo sempre ocorre sob a foma de agregados granulares com cristais anédricos. Esses agregados estão, geralmente, dispersos em matriz sericítica. Muscovita, epidoto, clorita e sericita ocasionalmente ocorrem nessas rochas como componentes subordinados ou como minerais acessórios (Fotomicrografia 08).

A análise modal de uma amostra de BIF (104) apresenta o quartzo com textura granoblástica poligonal como constituinte mineralógico principal $(81 \%)$, hematita $(16 \%)$ e estilpnomelano $(3 \%)$, que pode ser visualisada na fotomicrografia 09. 


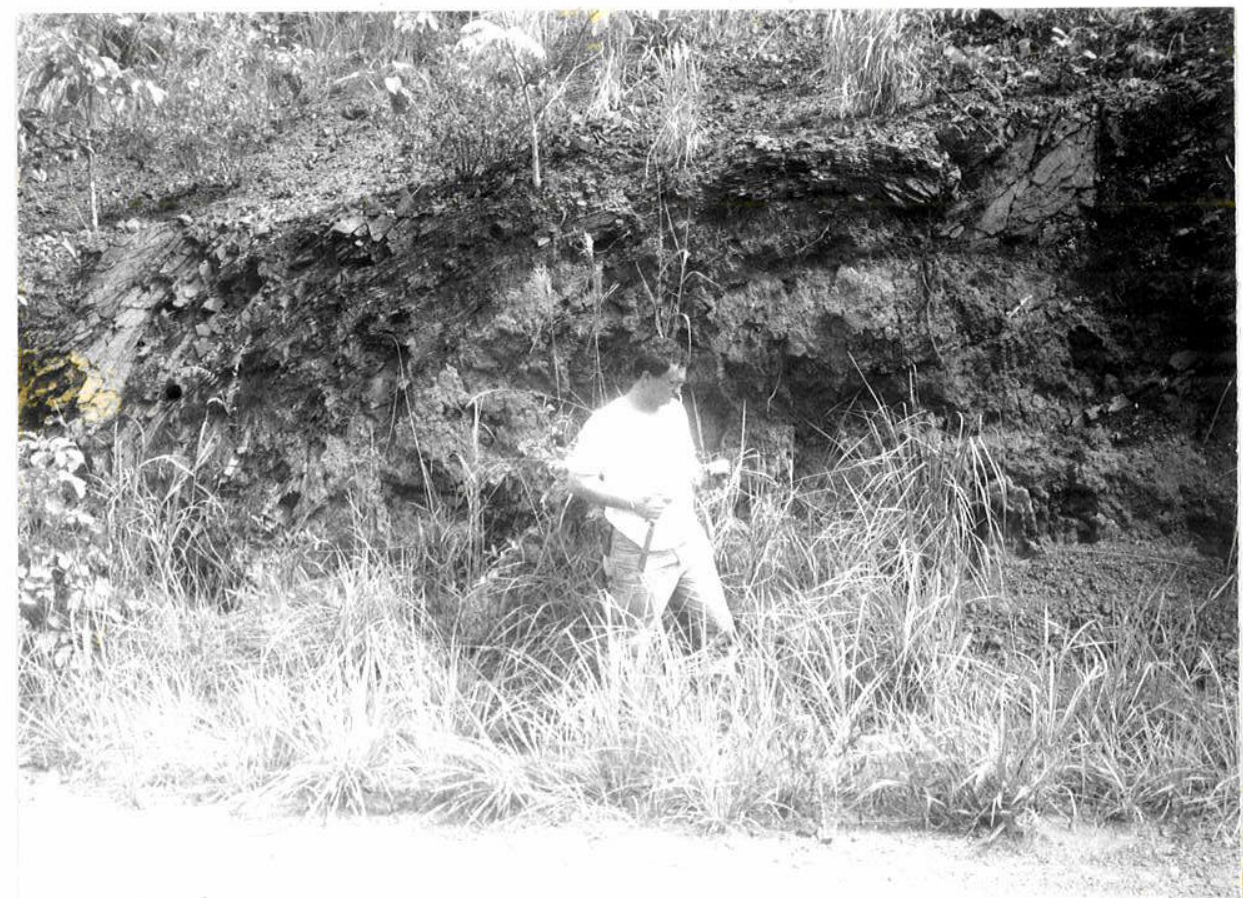

Foto 07 - Afloramento no 104 de formação ferrifera bandada ocorrendo próximo à Fazenda N.Sra. Aparecida (Figura 05). As BIFs. estão suavemente defornadas em dobras abertas, com plano axial mergulhando para SW. Entretanto, essa deformação suave corresponde a uma deformaçâo tardia tipo $D_{n+3}$, visto que essas rochas sofreram forte foliação de transposição na deformação principal $\left(\mathrm{D}_{n+1}\right)$, conforme represetaça da fotomicrografia no 09 .

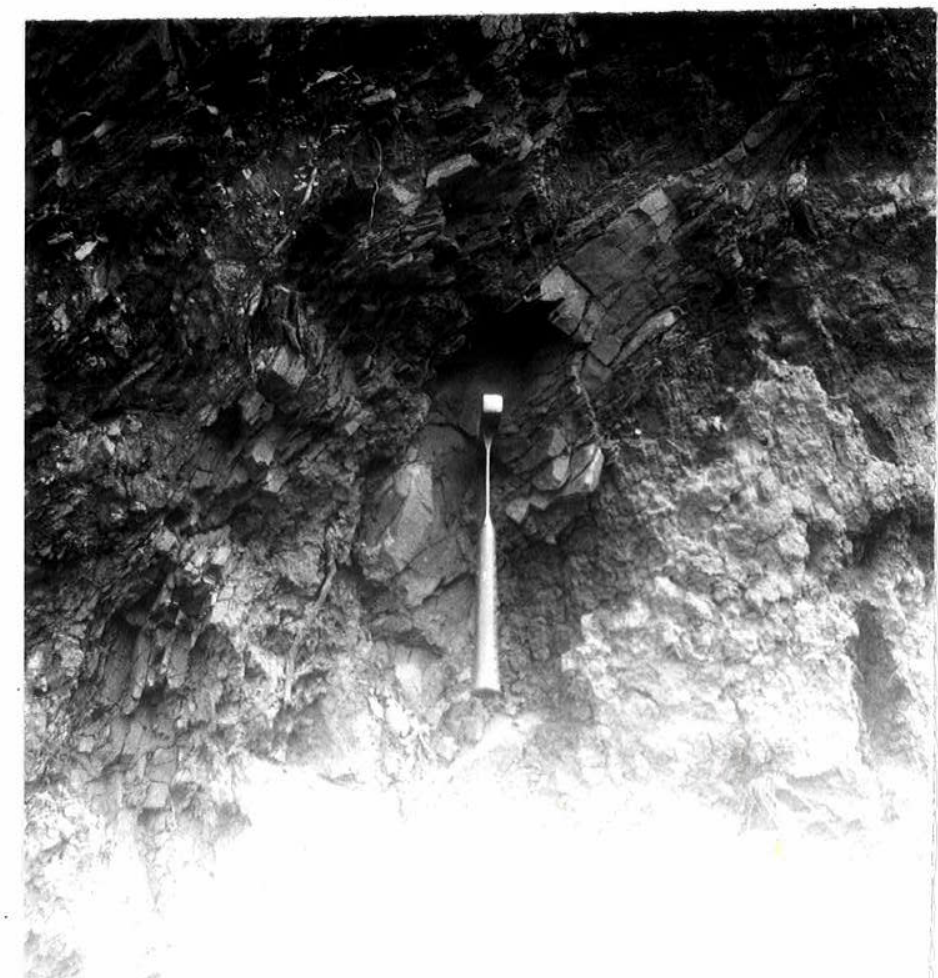

Foto 08 - Detalhe da foto anterior, mostra bandas hematiticas em alternância com bandas de metacherts. 


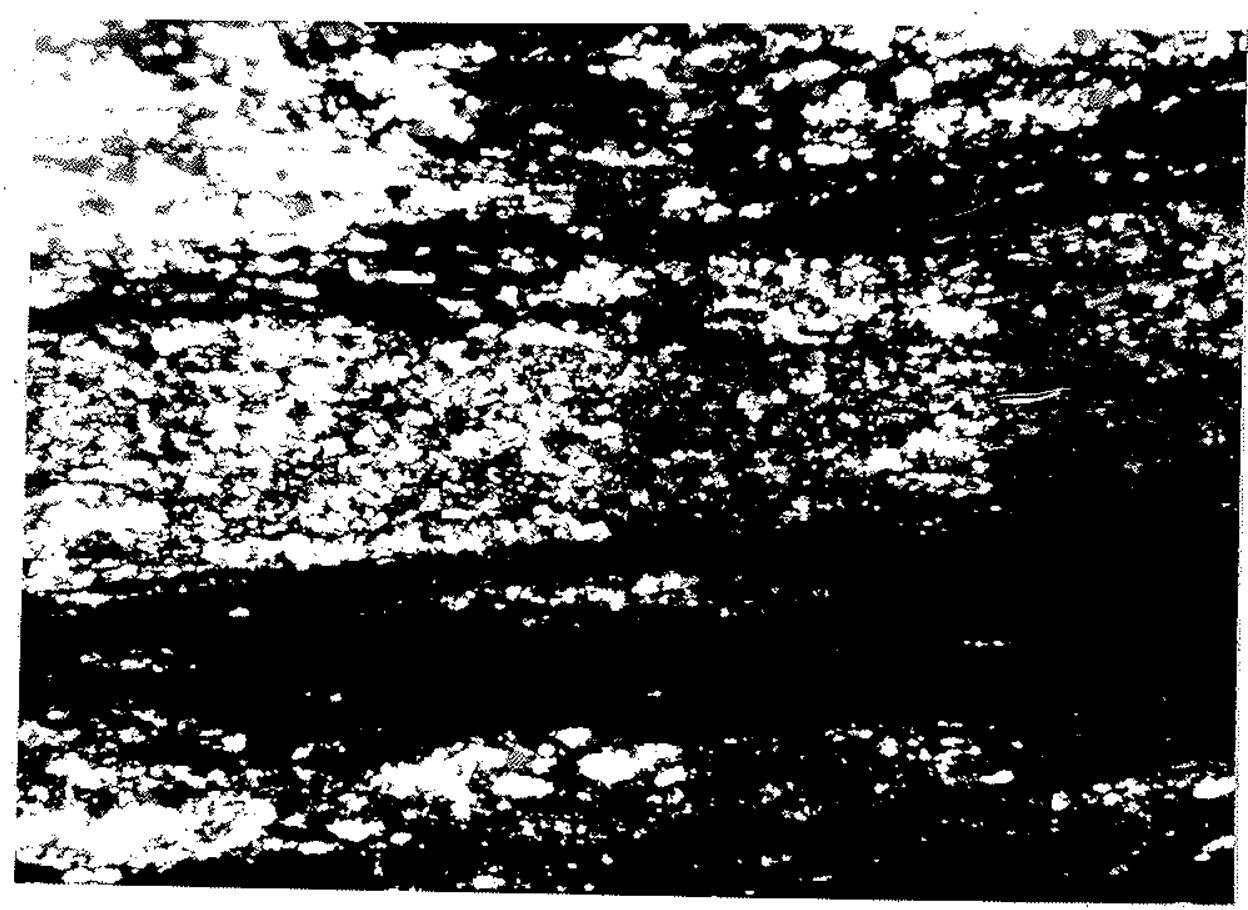

Fotomicrografia 08 - Seção no 104 , aumento $32 \mathrm{X}$ NX - Formação Ferrifera bandada, mostrando leitos de metachert alternando-se com leitos de hematita, onde é destacada a forte foliação de transposição causada na deformação principal $\left(\mathrm{D}_{n+1}\right)$

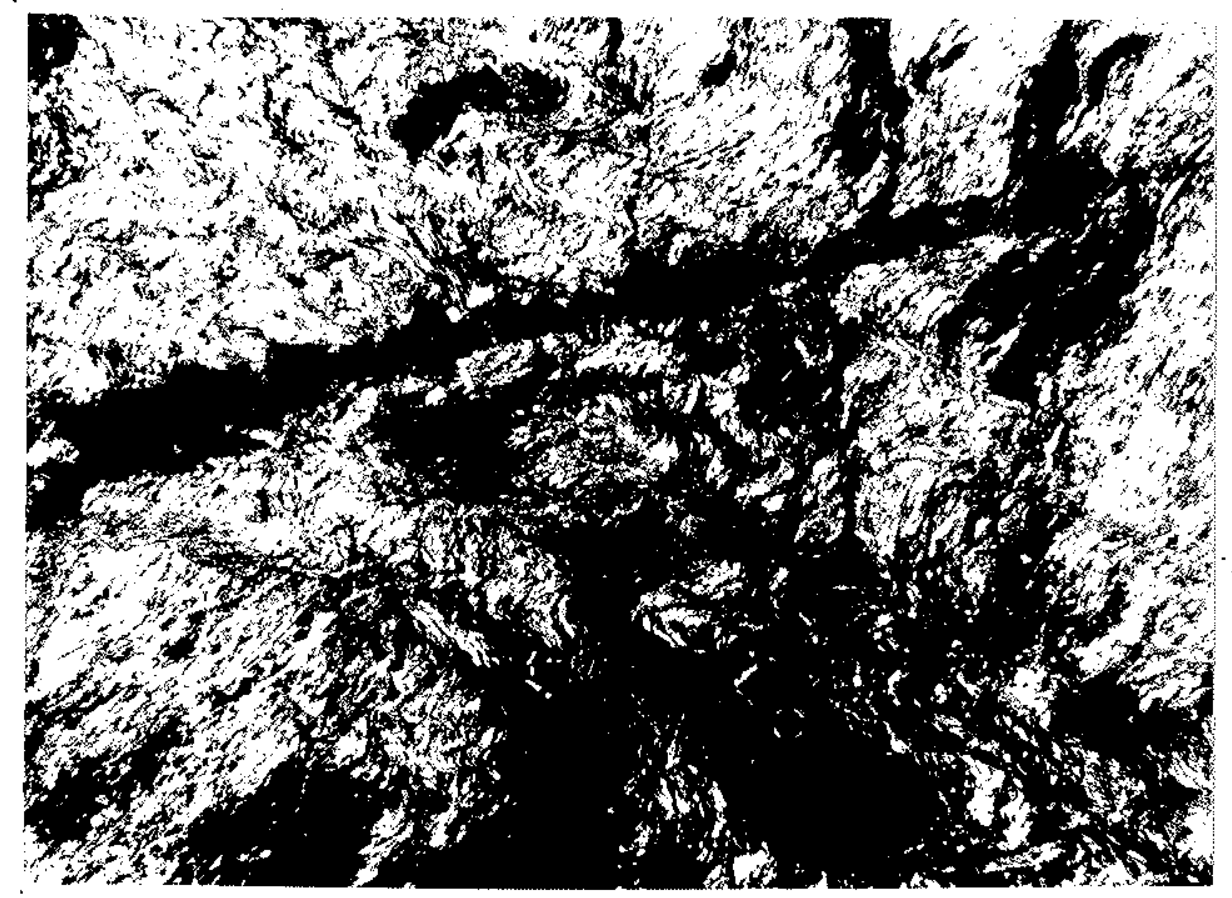

Fotomicrografia 09 - Seção no 13, aumento 32X/NX - Sericita xisto mostrando clivagem de crenulação $\left(D_{n+2}\right)$, posterior à deformação principal $\left(D_{n+1}\right)$ e percolação de óxidos de ferro nos planos de folịção e de fratura. 
TARELA (03 - Análises Modais de Quartzitos (Inoluindo Metacherts), Xistos - Formaçôes Ferrifferas Bandadas (\% Voli)

\begin{tabular}{|c|c|c|c|c|c|c|c|c|c|}
\hline AHOSTRAS & $B 3$ & 67 & 89 & 13 & 33 & 46 & 184 & 117 & 118 \\
\hline Quarrtzo & 38,1 & 43,4 & 85,3 & $13, a$ & 15,8 & 82,9 & 81,0 & 83,2 & 99,0 \\
\hline fruscovita & 9,8 & 5,3 & - & 69,1 & - & 15,7 & - & 15,1 & 1,0 \\
\hline Epidato & - & 3,3 & - & - & 4,8 & - & - & - & - \\
\hline clorita & - & 10,5 & - & - & 3,4 & 1,2 & - & - & - \\
\hline seriolta & - & 33,1 & - & 36,3 & - & - & - & - & - \\
\hline Direão & - & - & - & - & tr & tr & - & - & - \\
\hline Leucoxênio & - & - & - & - & - & $\operatorname{tr}$ & - & - & - \\
\hline fopacos. & - & - & - & - & - & - & - & 1,6 & - \\
\hline Hem/Nagnetita & - & - & 12,7 & - & 1,5 & - & 16,0 & - & - \\
\hline Estil promelano & - & - & 2,8 & - & - & $\therefore$ & 3,0 & - & - \\
\hline Granada & - & - & - & - & 6,2 & - & - & - & - \\
\hline Hicroolínio & - & - & - & $2, \theta$ & - & - & - & - & - \\
\hline
\end{tabular}

Legenda: Hem = Hematita 


\section{V.3. Intrusivas Máficas e Ultramáficas Metamorfizadas}

Essas rochas ocupan as partes sul, central e leste da área mapeada e são representadas por tipos petrográficos classificados como serpentinitos, gabros e tonalitos. A granulação dessas rochas é invariavelmente grossa a muito grossa, atestando o seu caráter plutônico. Gabros e serpemtinitos apresentan texturas cumuláticas que denunciam diferenciação "in situ". Os ternos litológicos constituintes do Complexo Gábrico variam desde peridotíticoharzburgítico até gabros e leuco-gabros, enquanto que o Complexo Serpentinítico é constituido por peridotitos, dunitos a harzburgitos metamorfizados, com texturas cumuláticas.

Oș metatonalitos ocorrem na parte central da área mapeada, dentro dos limites da Fazenda Santa Isabel, são rochas mesocráticas, com granulação média a grossa, ocorrendo sob a forma de matacôes dispersos por entre pastagens e vegetação nativa. A estrutura observada é comumente isótropa.

Os metagabros são rochas meso a melanocráticas, com gramulação grossa, estrutura reliquar (cumulática), com o anfibólio preto a esverdeado dominando aparentemente sobre o plagioclásio. Os litotipos com gramulação média poden apresentar foliação incipiente. A densidade desses litotipos é elevada. Seu modo de ocorrência principal é em forma de pequenos blocos, dispersos por entre a vegetação.

O metamorfismo exibido por essas rochas é o de fácies xistos verdes baixo, como demonstra a mineralogia expressa na tabela 04 , juntamente com sua moda. As características mineralógicas dessas rochas estão descritas a seguir.

\section{Metagabros:}

Ao microscópio, os plagioclásios apresentam-se quase sempre como cristais reliquiares, subédricos, saussuritizados, com vestigios de gemunação polissintética. Sua composição mais frequente é estimada dentro do campo da labradorita.

A hornblenda-tschermaquita comumente apresenta cor verdeescura, com forte pleocroismo verde. Os cristais podem atingir $7 \mathrm{~mm}$ com formas idioblásticas a subidioblásticas, hospedando poiquiloblastos de plagioclásio, clinopiroxênio, quartzo e opacos. A outra forma de anfibólio presente nos gabros é a tremolita-actinolita, que se distingüe da hornblenda-tschermaquita pela cor 
(incolor) e pela presença de pleocroísmo variando de incolor a verde-claro, com birrefringência elevada. É nitidamente formada a partir da alteração da hornblenda.

$O$ diopsidio pode alcançar porcentagens de até $23 \%$, sendo sua principal característica o relevo alto, incolor a verde pálido, com clevada birrefringência. As formas são idiomórficas, podendo ocorrer pequenos cristais como poiquiloblastos inseridos em hornblenda.

Epidoto, clorita, sericita talco e carbonatos são os minerais de alteração (secundários) mais freqüentes. Mostram hábito xenomórfico na maioria das ocorrências e são gerados a partir da transformação de plagioclásios, anfibólios e olivinas.

Os minerais acessórios mais comuns são apatita titanita e opacos.

à plagioclásios e anfibólios.

O quartzo (metamórfico) ocorre em alguns litotipos, associados

As fotomicrografias $10,11,12$ e 13 mostram as relações texturais presentes nessas rochas.

\section{Serpentinitos:}

A serpentina é o constituinte fundamental como demonstra a Tabela 04. A variedade mais freqüente é a crisotila. Esta é incolor, de relevo baixo, birrefringência fraca a moderada, extinção paralela e hábito fibroso. A textura é reliquiar (cunulática), onde olivina e cromita acessória representan a fase cumulus e orto + clinopiroxênios representam a fase intercumulus (Fotonicrografias $11,12 \mathrm{e}$ 13).

Os clinopiroxênios constituem os minerais mais preservados, enquanto que os ortopiroxênios e olivinas estão pseudomorfizados como núcleos de minerais reliquiares.

Clorita magnesiana, talco e apatita (além da cromita) são os minerais acessórios mais frequientes.

\section{Metatonalitos:}

Macroscópicamente são de cor cinza-clara, granulação média a grossa, estrutura maciça, às vezes porfiritica. Em uma amostra analisada ao microscópio (188), os minerais essenciais encontrados foram o plagioclásio, a hornblenda, biotita, quartzo e clorita, enquanto que os minerais secundários estão representados pelas seguintes fases: microclínio, epidoto e carbonatos e como acessórios, titanita, zircão, apatita e opacos.

O plagioclásio (48\%) é xenoblástico, com lamelas de geminação deformadas. Sua composição, estimada é de Anss (andesina). Os grãos encontramse iritensamente saussuritizados. 
A homblenda (7\%) tem cor verde, pleocroismo esverdeado, grãos xenoblásticos e relevo médio.

A biotita $(11 \%)$ é marron, com pleocroísmo marron-escuro, apresentando-se em forma de palhetas sub-idiomórficas. Intensa cloritização é
verificada.

O quartzo (27\%) é xenoblástico, em grãos intersticiais, evidenciando incipiente textura de recuperação/recristalização, como a individualização de subgrấos.

Clorita secundária ocorre, oriunda da substituição da biotita (cloritização). O epidoto e o carbonato ocorrem associados, advindos da decomposição dos plagioclásios.

Cristais inalterados de microclinio podem ocorrer, associados à titanita, zircão e apatita, com formas idiomórficas.

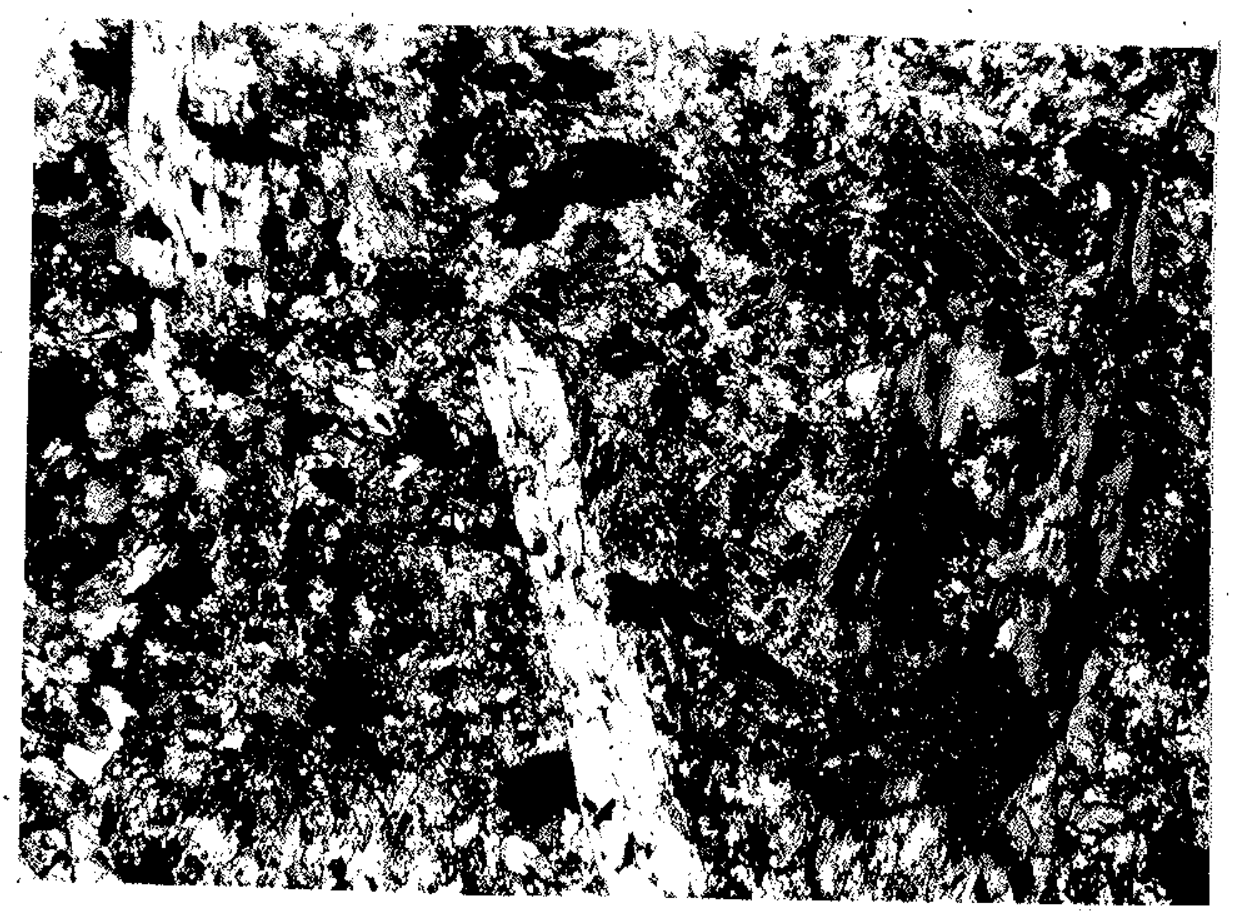

Fotomicrografia 10 - Seção no 102, aumento $32 X / N X$ - Dique máfico intrusivo na Sequência Vulcano-Sedimentar do Rio Alegre. A textura metamórfica desenvolveu-
se sobre uma textura porfirítica. 


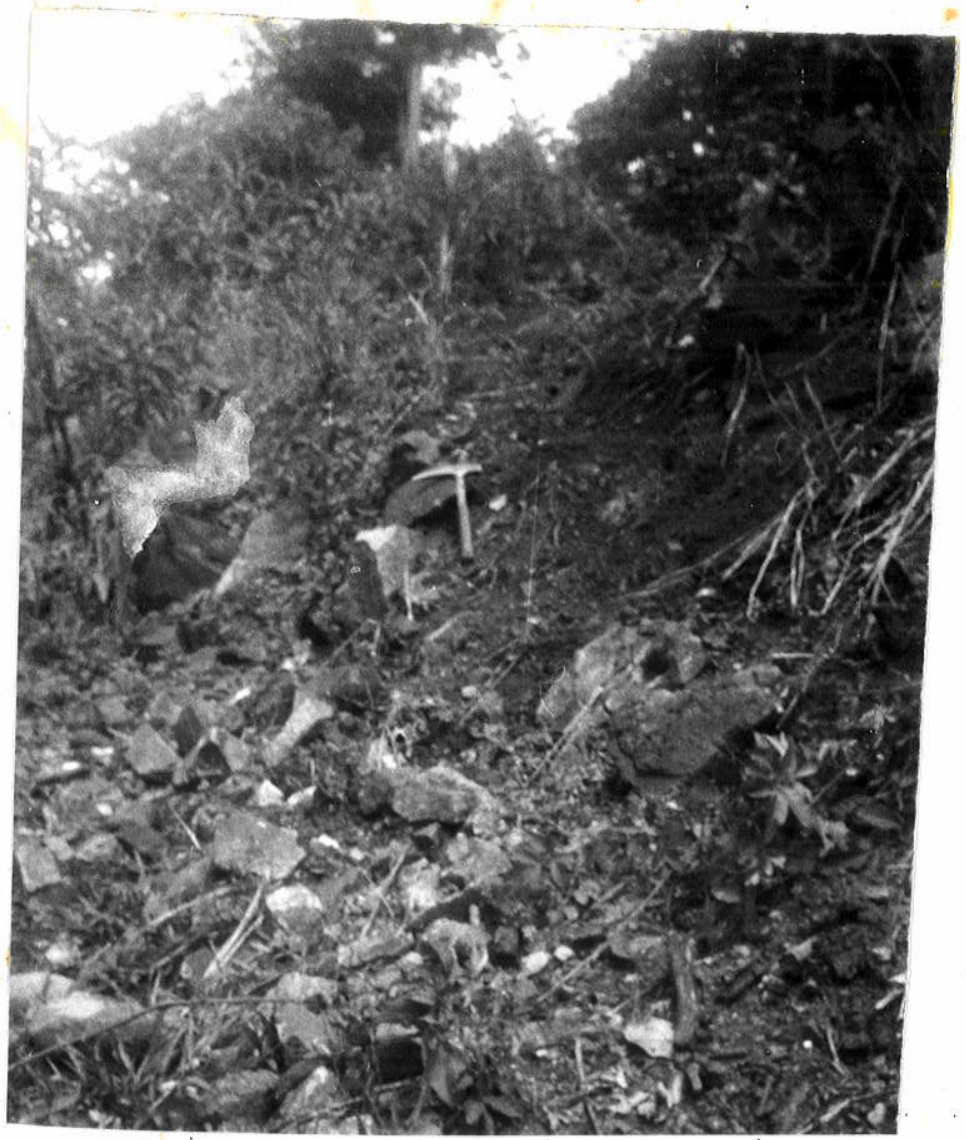
Foto 09 - Aspecto do afloramanto no 100 mostrando serpentinito próximo à Serra
Salto do Aguapei (Figura 05), sob forma de morrotes isolados.

Foto 10 - Detalhe da foto anterior, mosirando intenso fraturamento, com as
fraturas preenchidas por quartzo de silicificação.

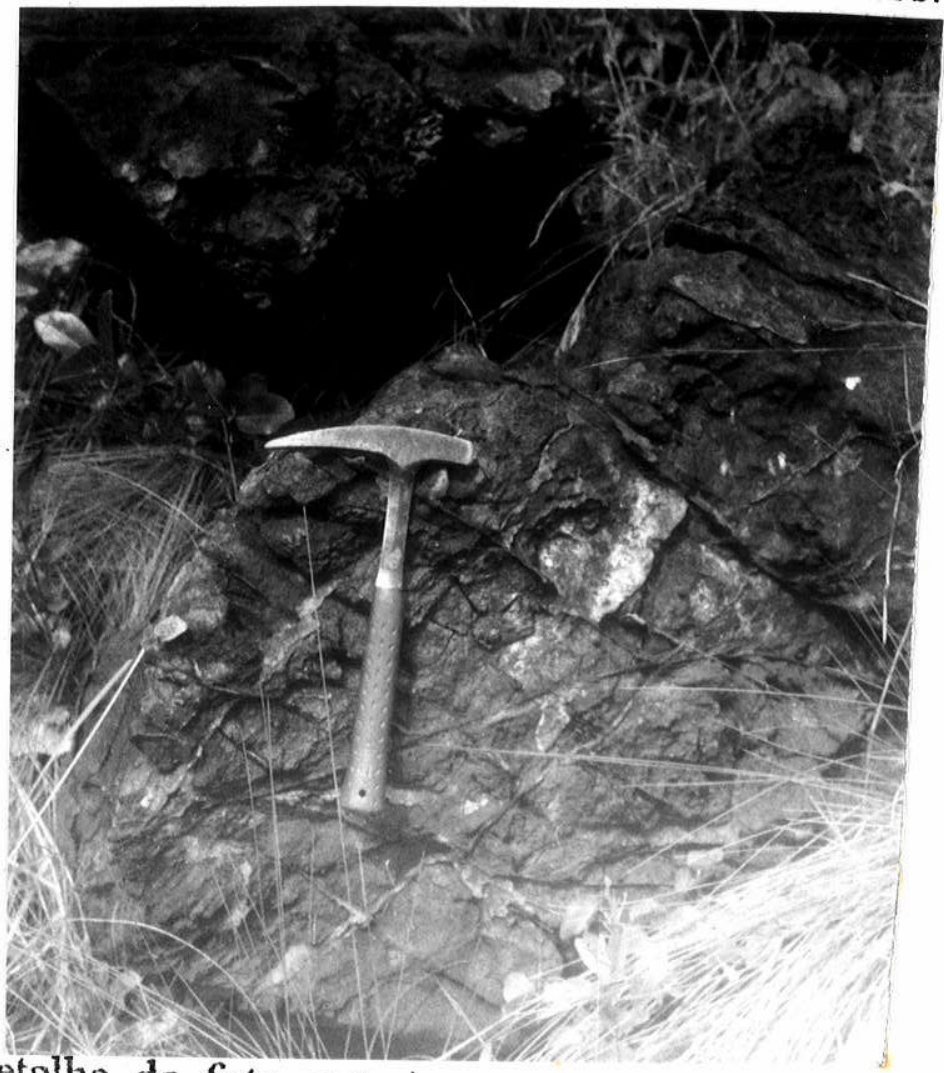




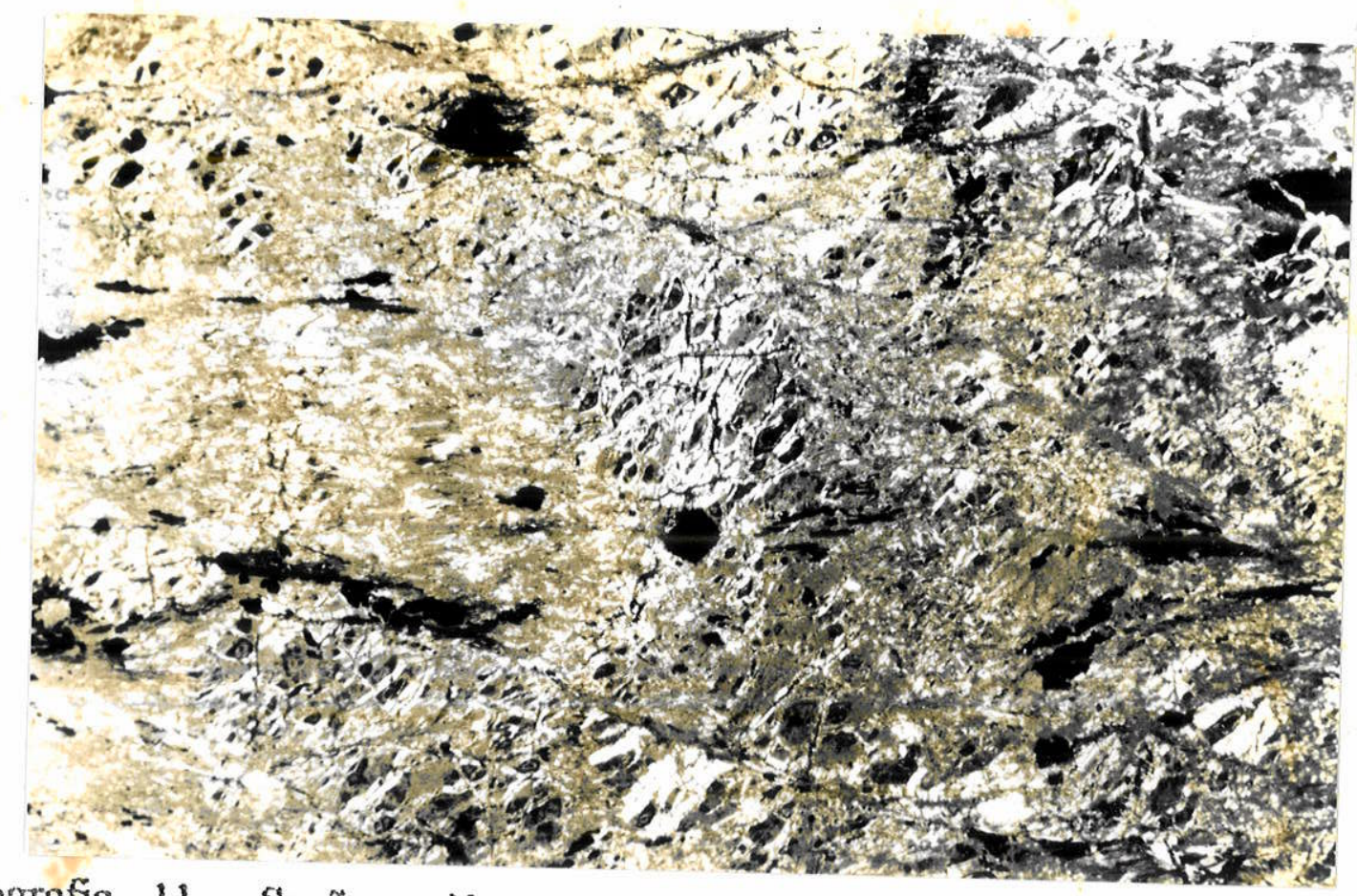

Fotomicrografia 11 - Seção no 40, aumento $25 \mathrm{X} / \mathrm{NX}$ - Mostra olivina cumulática com granulação grossa, pseudomorfizada para serpentina "em malha" e cromita acessória (opaca). Ocorrem ainda ortopiroxênios serpentinizados/cloritizados (áreas cinzentas entre as olivinas). A deformação/foliação é incipiente.

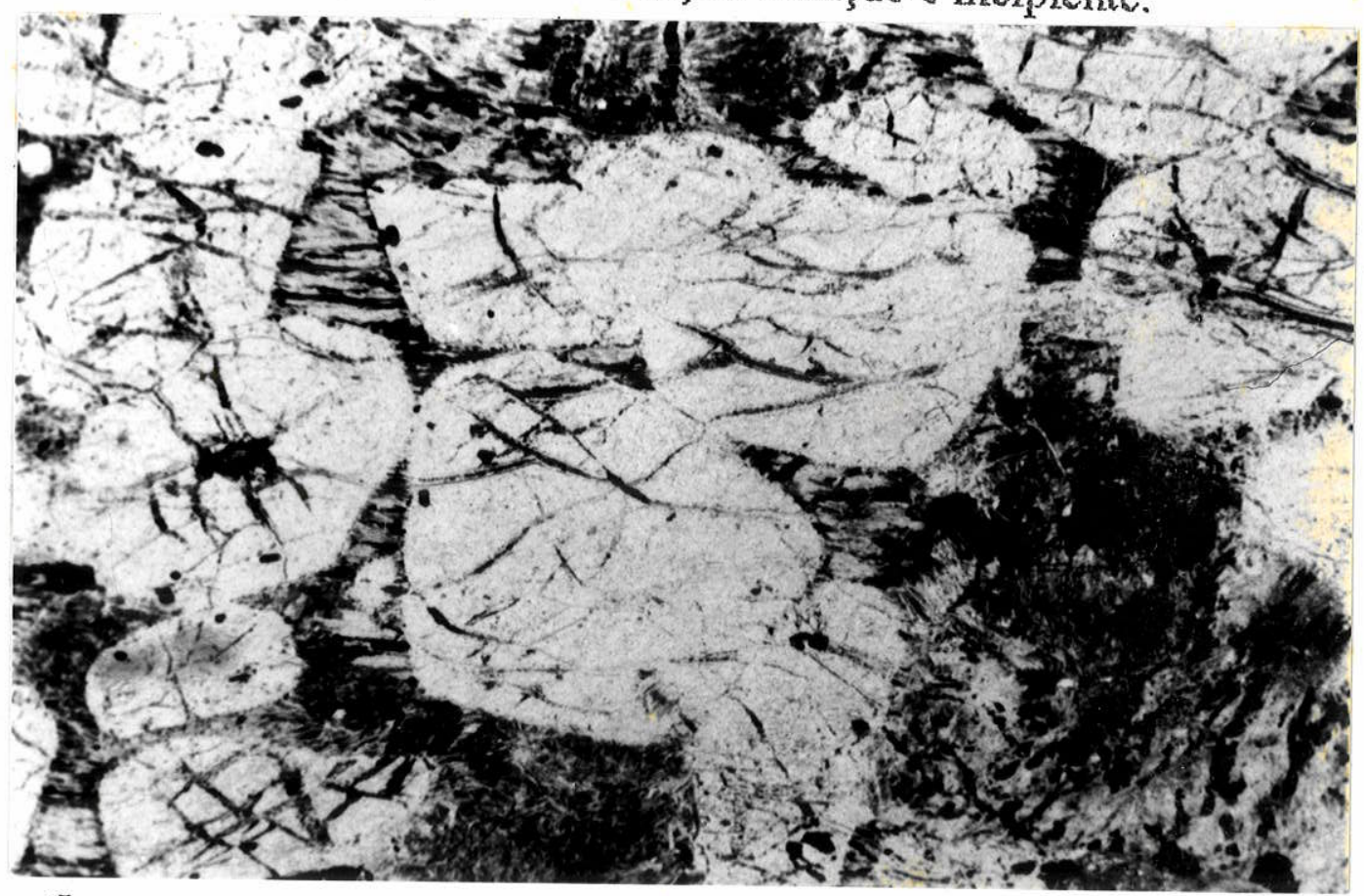

Fotomicrografia 12 - Seção no 100 , aumento $100 \mathrm{X} / \mathrm{NP}$ - Serpentinito apresentando olivinas cumuláticas idiomórficas serpentinizadas. O ortopiroxênio também está serpentinizado e/ou cloritizado e representa a fase intercumulus. com estrutura lamelar paralela. O clinopiroxênio está parcialmente preservado. Ocorre também cromita acessória. 


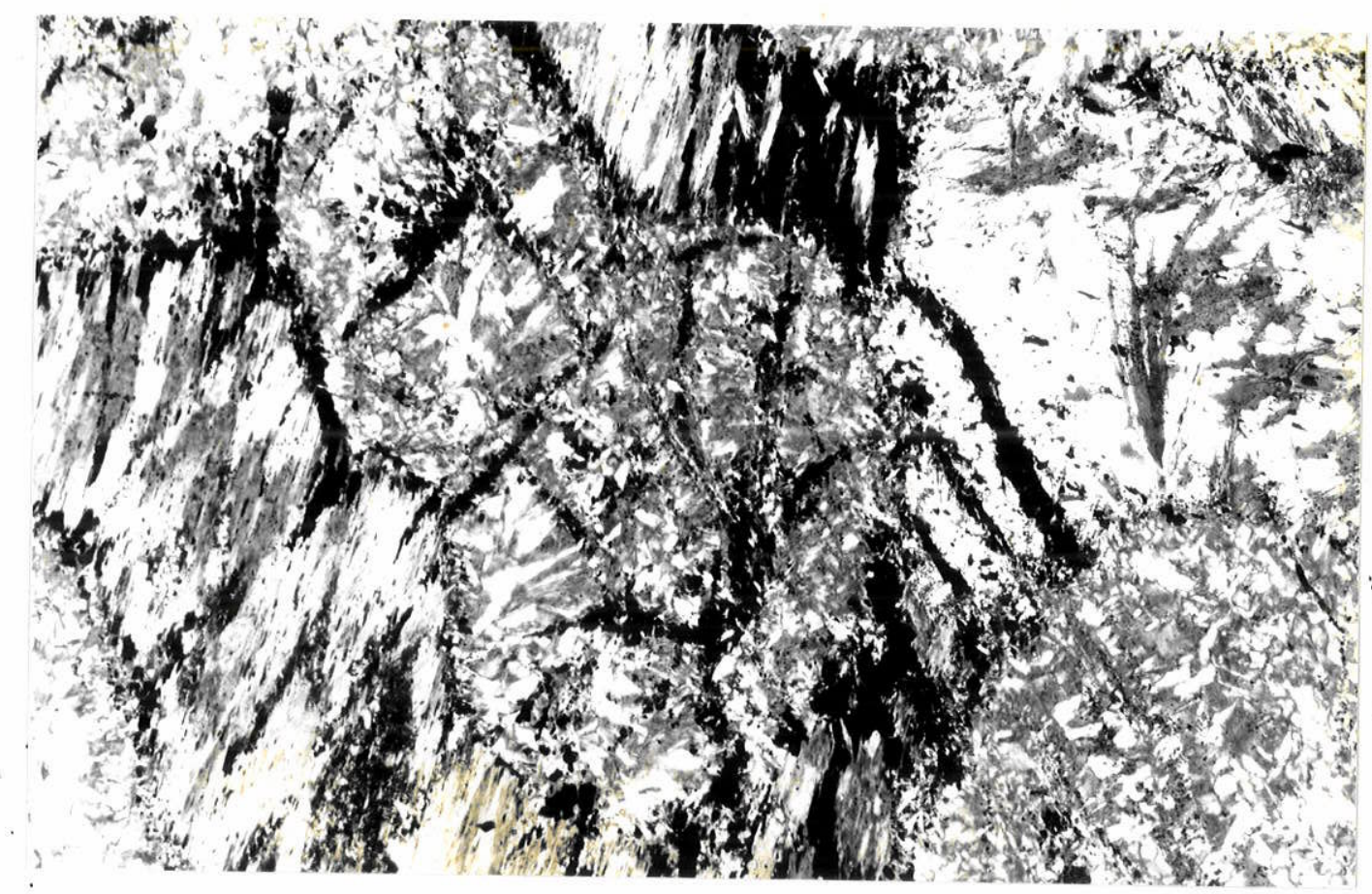

Fotomicrografia 13 - Seção no 39 , aumento 25 X/NP - Outro aspecto de textura cumulática em metaperidotito.

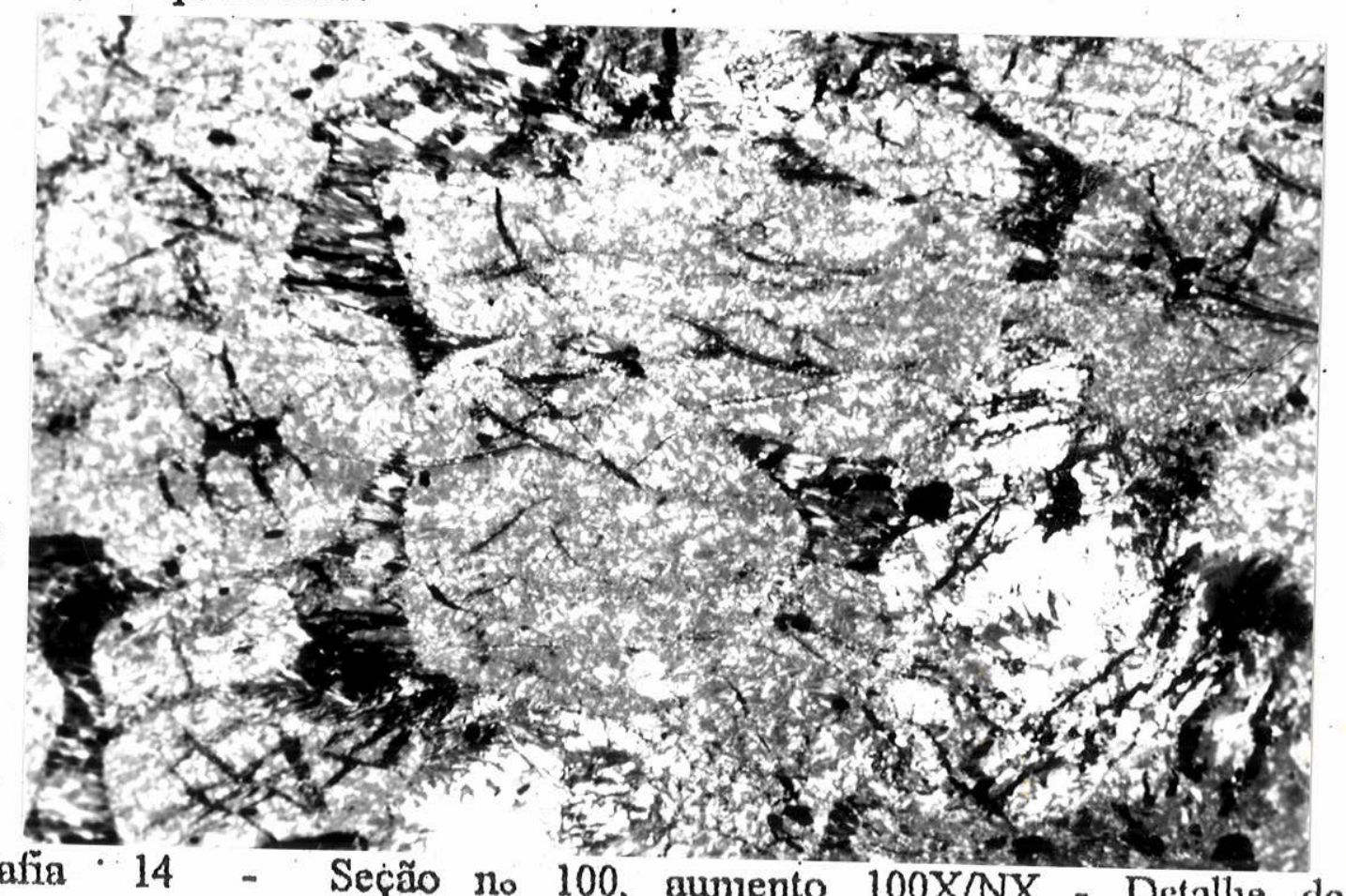

Fotomicrografia 14 - Seção no 100 , aumento $100 \mathrm{X} / \mathrm{NX}$. Detallie da fotomicrografia anterior, porém com polarizadores obliquamente cruzados. As partes mais claras (brancas) representam clinopiroxênios parcialmente preservados. 
TASELA 84 - Análices Modais de Hatagabros e Hetaultrasafitos (y Hol.)

\begin{tabular}{|c|c|c|c|c|c|c|c|c|c|c|c|c|c|c|c|}
\hline AHERAIS & 82 & 84 & $23^{4}$ & 3 & $31 \mathrm{a}^{3}$ & $39^{7}$ & $49^{7}$ & $41^{3}$ & 43 & $45^{3}$ & 19 & 120 & $126^{3}$ & $\$ 2\}$ & $\$ 32$ \\
\hline Plagioclásio & - & 13,3 & 48,8 & 35,2 & 23,1 & - & - & - & 42,8 & 28,3 & - & 35,3 & 53,3 & 18,8 & 11,6 \\
\hline Clinoqiroxênio & 8,3 & 23,1 & - & 15,3 & - & - & - & - & $\because$ & - & 3,3 & 3,2 & - & - & 1,2 \\
\hline Hornd/schem. & - & 38,4 & - & 32,5 & - & - & - & - & $5 a, 3$ & 46,4 & - & 42,1 & 27,3 & $2 \xi, 3$ & 22,1 \\
\hline Trem/Aatinolita & - & - & 35,3 & - & 23,3 & - & - & - & - & 16,2 & - & - & - & - & - \\
\hline Eqidete* & - & $t r$ & 8,4 & tr & 3,5 & - & - & - & - & - & - & 6,3 & 18,2 & 44,1 & 4,3 \\
\hline Clonita" & - . & 15,9 & 5,8 & 13,1 & 36,4 & - & - & - & - & 6,8 & - & 2,1 & tr & 5,1 & - \\
\hline Titanita & - & $t_{r}$ & tr & - & - & - . & - & - & - & 1,1 & - & 1,2 & - & - & - \\
\hline Serpentina & 91,3 & - & $i r$ & - & - & 36,3 & 31,9 & 82,3 & - & - & 83,5 & - & - & - & - \\
\hline Olivina & 1,6 & - & - & - & - & 1,8 & 5,3 & $5,3$. & - & - & 5,8 & - & - & - & - \\
\hline 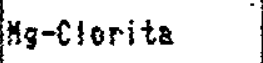 & 1,2 & - & - & $\therefore$ & - & - & - & 1,3 & - & - & - & - & - & - & 35,1 \\
\hline Popacos & $1,8$. & 1,8 & tr & tr & - & 1,3 & 2,4 & tr & $\because$ & - & - & tr & - & - & - \\
\hline Quartzo & - & tr & 3,1 & - & - & - & - & - & - & - & - & tr & 3,6 & 5,4 & - \\
\hline zoi/clinozois. & - & - & 11,1 & - & - & - & - & - & - & - & - & - & to & 8,3 & - \\
\hline Sericita & - & 5,3 & tr. & 3,9 & 9,2 & - & - & - & - & tr & - & 9,8 & - & - & 25,3 \\
\hline Hoatita & - & - & - & - & - & - & - & - & 1,4 & tr & - & tr & - & - & - \\
\hline K-Feldspatos & - & - & - & - & - & - & - & - & - & - & 1,8 & - & - & tr & - \\
\hline Cromita & - & - & - & - & 8,5 & - & - & - & - & 1,6 & - & - & - & - & - \\
\hline$\{a \mid 00$ & - & - & - & - & 8,5 & - & - & - & - & - & - & - & - & - & - \\
\hline Leucoxenio & - & - & $t$ & - & - & - & - & - & - & - & - & - & - & - & tr \\
\hline
\end{tabular}

Legenda: * Wintrais de Alteraçă丶

* Rochas Metaultriméficas.

* Diques Hetatásicos suturulốnicas. 


\section{V.4. Granito-Gnaisse Santa Helena}

Os btotipos pertencentes à unidade Granito-Gnáisse Santa Helena, macroscópicamente são leucocráticos, com cores variando de tons rosados a cinzas, con variações texturais/estruturais em função de sua localização. Ocorrem tipos e intensidades diferentes de deformação, gerando litotipos variados tais cono: metagranito, granito-gnaisse e biotita-gnaisse, sempre ostentando a composição $3 b$. A moda dessas rochas está representada na tabela 05 .

Microscopicamente, os granito-gnaisses presentes na área mapeada são freqüentemente equigramulares, com textura isótropa, contendo os seguintes minerais essenciais: plagioclásio, quartzo, microclinio e ottoclásio (Fotomicrografia 15).

O feldspato alcalino frequientemente apresenta-se como ortoclásio nas rochas menos deformadas, enquanto que nas fortemente deformadas predominam os microclínios, com extinção ondulante, estirados, com deformação de maclas, saussuritizados, com presença de fraturas de cisalhamento.

Processos de recuperação/recristalização tais como: individualização de sub-grăos e recristalização marginal de grãos de quartzo em tomo de porfiroclastos (textura mortar) são observáveis.

O quartzo apresenta forte extinção ondulante e podem ser visualisados, também; grãos estirados com nítidas bandas de deformação, com presença de sub-grãos e texturas de recuperação/recristalização, denunciados pela presença de grãos individualisados com junções poligonais.

O plagioclásio apresenta grãos sub-idiomórficos com freqüente intercrescimento mirmequítico, quase sempre em processo de saussuritização. Nas regiões de maior deformação, eșse mineral ocorre em grãos xenoblásticos, com contornos irregulares e clastos estirados, deformados e/ou fragmentados, geralmente com extinção ondulante e lamelas de geminação deformadas.

A biotita presente nessas rochas $(5 \%)$, ocorre como lamelas de exsolução associadas à clorita e opacos. O pleocroismo do marron até tons amarelados. Feições de "kink bands", grãos deformados e fragmentados, associados à extinção ondulante ocorrem freqüentemente nesses minerais.

Os minerais de alteração se apresentam comumente sob a forma de sericita, epidoto, carbonatos e clorita, ocorrendo como cristais subédricos a anédricos.

Os minerais acessórios se fazem representar por zircão, apatita e opacos, sob a forma de inclusões, ou agregados à fina matriz saussuritizada. 
Tabela as - Análises Madais de tranitóides Santa Helena ( Vol.)

\begin{tabular}{|c|c|c|c|c|c|}
\hline AMOSYRAS & 01 & $01 a$ & 21 & 26 & 189 \\
\hline Plaglaolásio & 25.4 & 26.6 & 23,1 & 33,7 & 35,8 \\
\hline$k-F u l d e p a t o s$ & 36,4 & 32,1 & 21,2 & 19,3 & $95, j$ \\
\hline puarkzo & 35,6 & 36,2 & 35,7 & 32,8 & 30,3 \\
\hline Biotita & 1,3 & 2,2 & 5,4 & 1,1 & - \\
\hline fapacos & 8,1 & - & 2,8 & - & 1,7 \\
\hline Huscovita & 1,8 & - & - & - & 2,6 \\
\hline Sericita & 8.3 & - & - & - & 8,1 \\
\hline $21 \times 0 \pi$ & tr & - & - & - & tr \\
\hline Epidoto" & - & 1,7 & - & - & - \\
\hline Cartonatos" & - & - & - & 8.9 & 0,5 \\
\hline florita & - & 1,1 & 3,1 & 4,8 & 7,6 \\
\hline
\end{tabular}

Legendat * Kinerais de Alterąão 


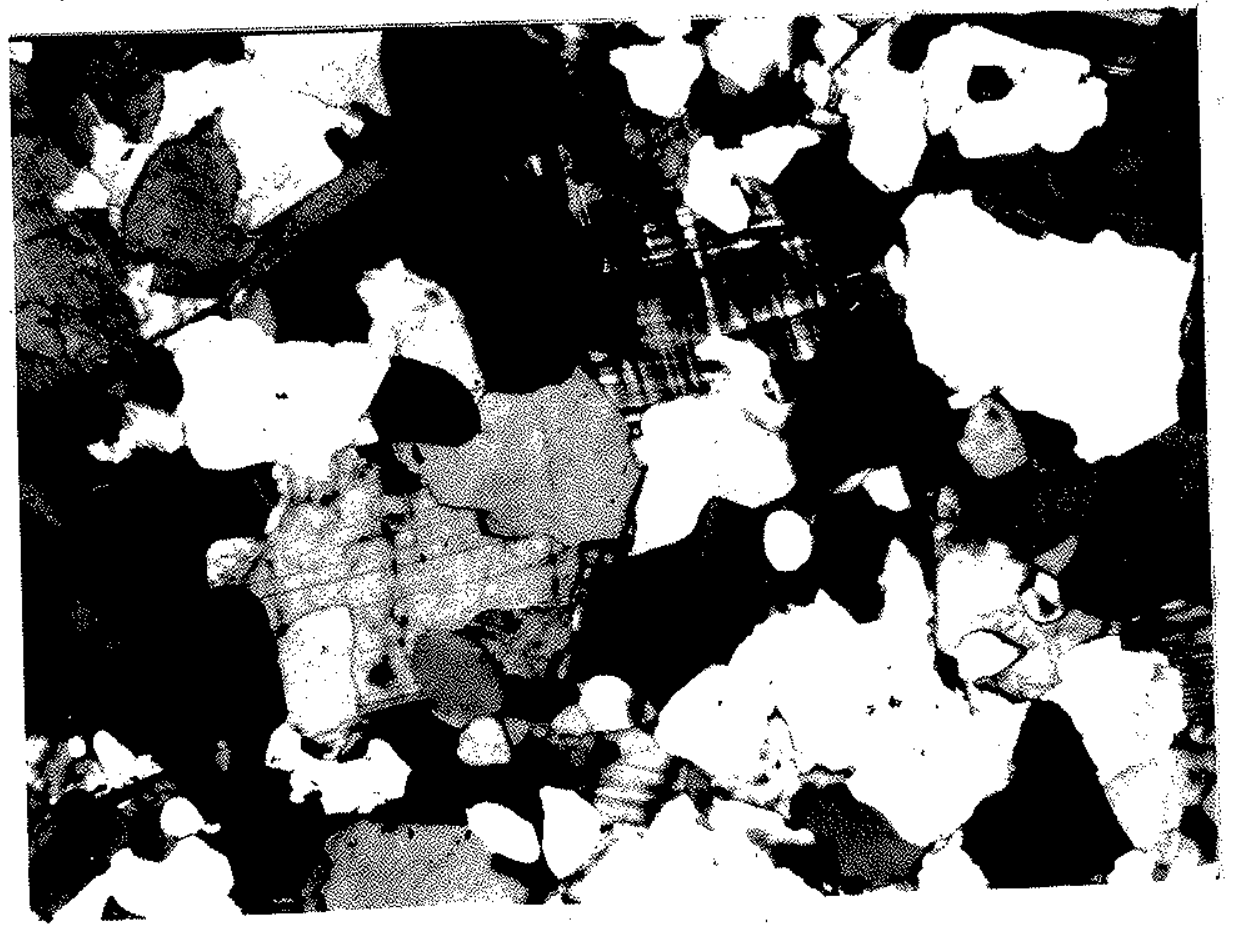

Fotomicrografia 15 - Seção no 01, aumento $32 X \mathrm{NNX}$ - Granitóide Santa Helena, com textura isótropa, pouco deformado. 


\section{V.5. Grupo Aguapeí}

No Grupo Aguapei ocorre uma grande diversidade de litotipos como os que se seguem: muscovita-quartzo xisto, meta-arcósios, metaconglonerados, filitos e ainda protomilonitos quartzosos. A estrutura mais caracteristica dessas rochas é a xistosidade, sendo que esta varia desde a foma incipiente até a fortemente impressa, dobrada ou crenulada (Fotomicrografia 16)

Os litotipos com deformação incipiente apresentam trama sedimentar preservada, onde a estrutura maciça é a mais característica e as texturas clásticas reliquiares se sobressaem. Nos litotipos catadásticos, a matriz varia, com presença de texturas vítreas, granoblásticas poligonais e/ou interlobuladas. Na fração grossa da rochas há porfiroclastos de quartzo, em vários estágios de deformação e recuperação (Fotomicrografĩa 17).

Os metaconglomerados possuem clastos de quartzo leitoso, com granulometria variável (seixos de até $5 \mathrm{~cm}$ de eixo maior), com baixos valores de arredondamento e esfericidade. A matriz é geralmente formada pelo par sericita + clorita.

O metamorfismo ostentado pelos litotipos pertencentes ao Grupo Aguapei é barroviano de fácies xistos verdes baixo (Zona da Cloriba), interpretado com base nas paragêneses presentes nas variedades petrograficamente descritas. 


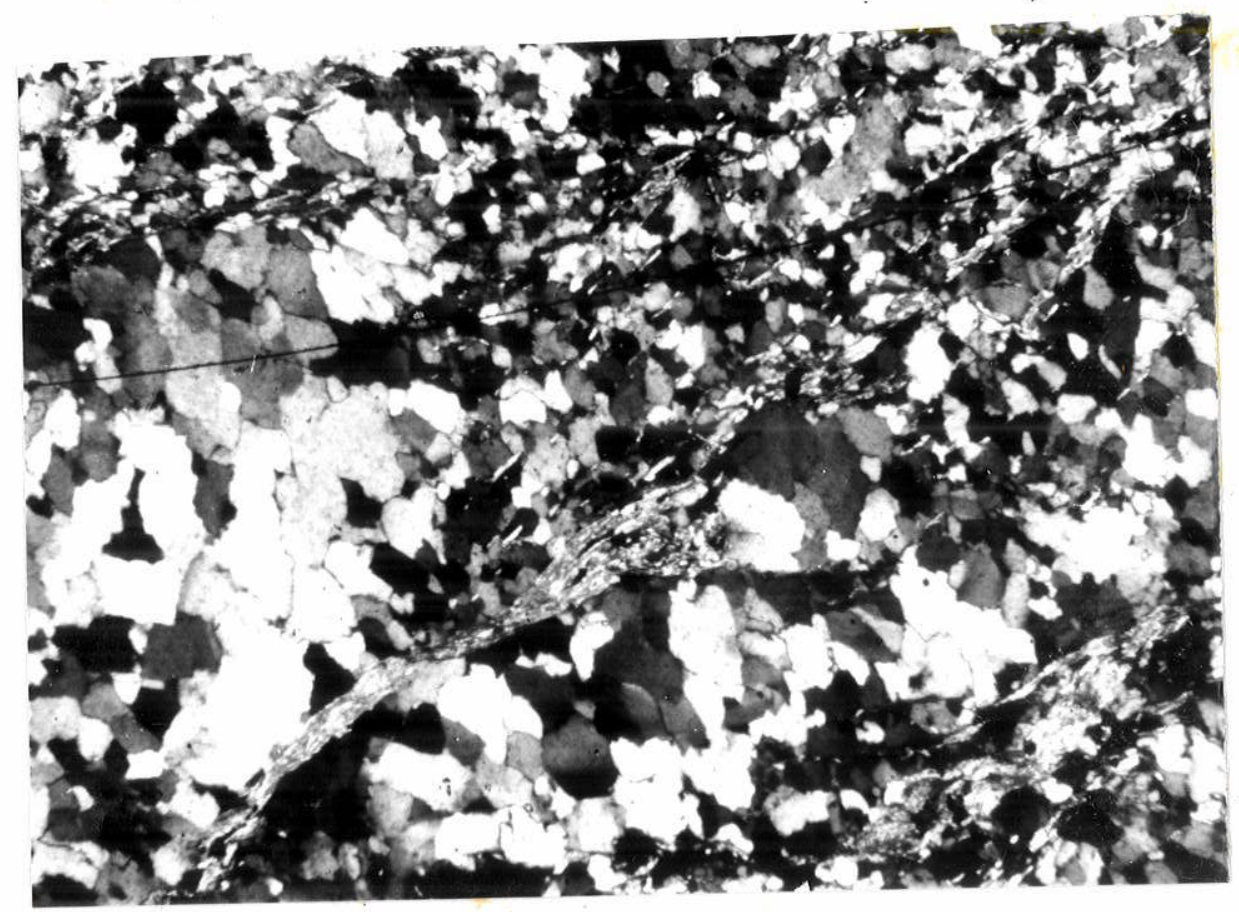

Fotomicrografia 16 - Seção no 09, anmento 32X/NX - Muscovita quartzito. Faixas micáceas com clivagem de crenulação. Feições de recuperação/recristalização de quartzo são frequentes no Grupo Aguapeí.

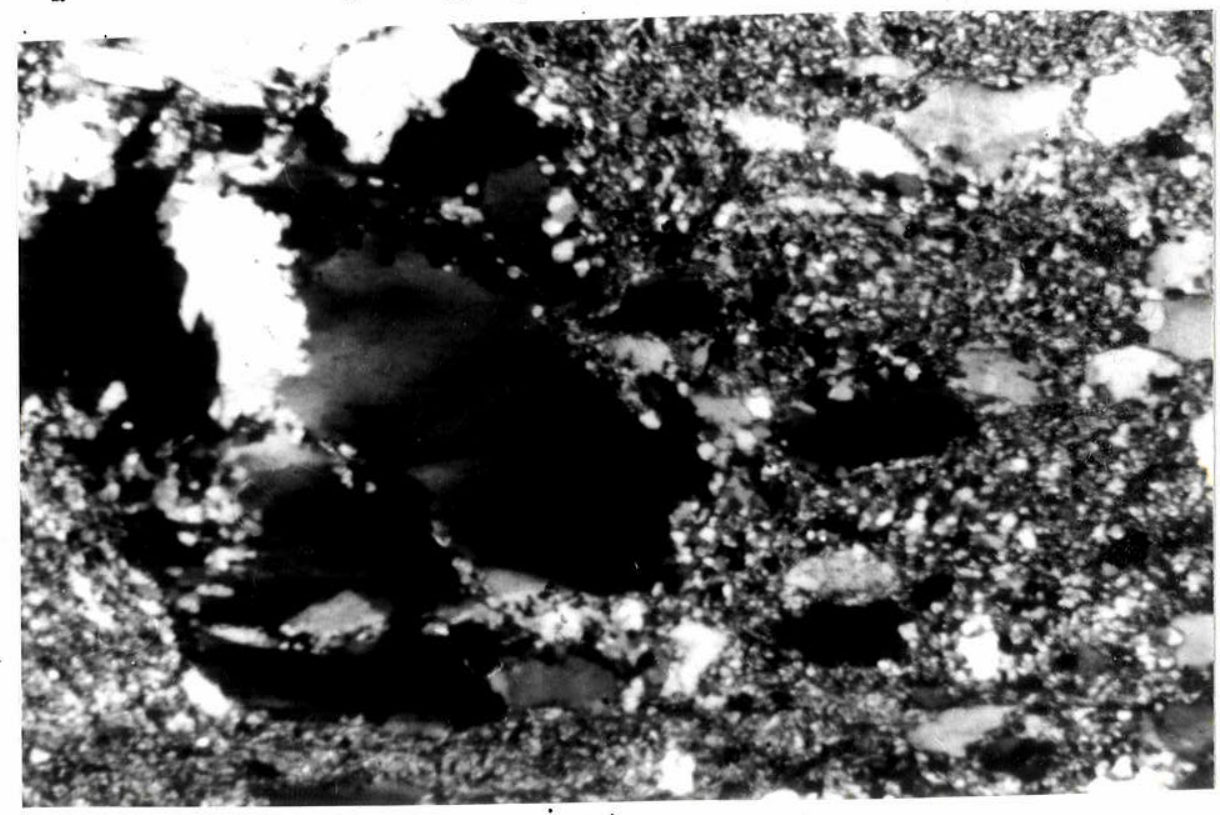

Fotomicrografia 17 - Seção no 46, aumento 32/NX - Metaconglomerado cataclástico com matriz quartzo-sericítica e porfiroclastos de quartzo deformados e parcialmente recristalizados. 


\section{CAPÍTULO VI}

\section{GEOQUIMMICA}

Estudos geoquímicos multielementares foram realizados em 25 (vinte e cinco) amostras de rochas máficas e ultramáficas (efusivas e intrusivas), intermediárias, ácidas e sedimentares (formaçôes ferriferas bandadas), metamorfizadas na fácies dos xistos verdes, todas provenientes da Sequênencia Vulcano-Sedimentar do Rio Alegre e dos corpos intrisivos de natureza gábrica e ultramáfica que ocorrem, respectivamente, na parte central e leste da área estudada.

Os afloramentos de proveniência das amostras foram discriminados no mapa de afloramentos (Fig.05) e todas as com análise química foram petrograficamente estudadas.

As análises foram realizadas no laboratório do Instituto de Geociências da Universidade de Hamburgo, República Federal da Alemanha. Os dados analíticos britos encontram-se listados nas tabelas 06 a 10 . Estas, foram efetuadas pelo método de Fluorescência de Raios $X$ Sequiencial Automática (Espectrômetro PHILIPPS) em pastilhas de fusão. Os limites de deteção e desvios-padrão são mostrados no anexo 01 .

Para essas análises, os valores de LOI (perda ao fogo) listados, representam o LOI (total), ou seja, LOI(tota) $=\mathrm{LOI}\left(\right.$ real $\left.>3.100^{\circ} \mathrm{C}\right)+\mathrm{H}_{2} \mathrm{O}(-\rightarrow)\left(<10^{\circ} \mathrm{C}\right)$.

A escolha das amostras para os trabalhos geoquímicos seguiu critérios petrográficos, entretanto, praticamente a integra das amostras analizadas apresentaram paragêneses minerais indicativas de alterações de origens diverșas: hidrotermais pré-metamórficas e/ou metamórficoimetassomáticas. Isto restringe a potencialidade interpretativa dos dados quanto ao quimismo de detalhe dos protólitos pré-metamórficos das rochas estudadas, conforme será discutido em cada um dos grupos de rocha analisadas.

O tratamento dos dados foi feito em microcomputador, utilizando o programa NEWPET (CLARKE, 1990-1992). 


\section{VI.1. Geoquímica da Seqüência Vulcano-Sedimentar do Rio Alegre}

Da Seqüência Vulcano-Sedimentar do Rio Alegre foram. analizadas diversas rochas metabásicas (anfibolitos), extrusivas e subvulcânicas, rochas meta-intermediárias a meta-ácides e algumas rochas metassedimentares a metavulcanoclásticas: Os dados analíticos brutos das rochas meta-ígneas, básicas a ácidas são mostrados na tabela 06.

As amostras 15, 15a,15b,25,27,122 e 126 são metabasitos e as rochas 12 e 107 são rochas meta-intermediárias transicionando para meta-ácidas. Das rochas metabásicas (anfibolitos), as amostras 15, 15a, 15b, 25 e 122 são de granulação fina, de origem efusiva, enquanto que as amostras 27 e 126 são, respectivamente, de gramulaçăo média e média-grossa, equigramular e porfirítica, ambas de origem subvulcânica. Devem ser destacadas ainda, fortes alteraçőes/transformações mineralógicas, principalmente de epidotização, que afetaram as amostras $15,15 \mathrm{a}, 15 \mathrm{~b}$ e 122, ou seja, principalmente as rochas básicas extrusivas. Essas alterações são atribuidas à processos hidrotermais/metassonnáticos pré-metamórficos, com possibilidade de tratar-se de alteraçốes do tipo fundo oceânico.

Nas rochas meta-ácidas, observam-se principalmente fraca carbonatação, associada a processos de saussuritização dos plagioclásios e cloritização dos minerais máficos. Notam-se ainda teores consideráveis de muscovita.

Apesar das alterações mineralógico-petrográficas mencionadas e, principalmente, em função de não terem sido encontradas amostras sem alteração, serão tentados alguns tratamentos e interpretaçôes geoquímico-petrogenéticas, com base nos dados analíticos obtidos. Inicialmente serão efetuadas algumas consideraçóes sobre possíveis problemas dos dados analiticos brutos e as respectivas adequações (recálculos eventuais), bem como análises e tratamentos geoquimicos preliminares, discriminantes, para verificar a possivel importância e expressão geoquímica das alteraçôes mineralógico-petrográficas inicialmente mencionadas.

Quanto aos dados analiticos brutos (Tabela 06), verificam-se algumas propriedades químicas anômalas quando consideradas em comparação 


\begin{tabular}{|c|c|c|c|c|c|c|c|c|c|}
\hline Sagple & JHO15. & J4015A & JM015B & J4025 & JM027 & JM122 & JM126 & 34012 & JK10? \\
\hline $\begin{array}{l}\mathrm{SiO}_{2} \\
\mathrm{TiO}_{2}\end{array}$ & 49.46 & 47.12 & 45.16 & 51.26 & 51.30 & 52.80 & 49.10 & 66.31 & 64.10 \\
\hline $\begin{array}{l}\mathrm{TiO}_{2} \\
\mathrm{Al}_{2} \mathrm{O}_{3}\end{array}$ & 1.27 & 1.17 & 0.83 & 1.23 & 0.80 & 1.50 & 0.95 & 0.35 & 0.42 \\
\hline $\begin{array}{l}\mathrm{Al}_{2} \mathrm{O}_{3} \\
\mathrm{Fe}_{2} \mathrm{O}_{3} *\end{array}$ & 12.39 & 17.75 & 16.26 & 14.30. & 15.70 & 16.10 & 13.20 & 14.74 & 18.10 \\
\hline $\begin{array}{l}\mathrm{Fe}_{2} \mathrm{O}_{3} * \\
\mathrm{HnO}\end{array}$ & 12.31 & 10.61 & 12.71 & 9.41 & $9.40^{\circ}$ & 12.81 & 16.06 & 2.88 & 1.42 \\
\hline $\begin{array}{l}\mathrm{SnO}_{\mathrm{O}} \\
\mathrm{H} \mathrm{O}\end{array}$ & 0.16 & 0.13 & 0.18 & 0.14 & 0.15 & 0.22 & 0.26 & 0.05 & 0.04 \\
\hline $\mathrm{HgO}$ & 5.64 & 4.15 & 4.26 & 6.89 & 6.14 & 4.04 & 6.79 & 1.22 & 1.03 \\
\hline $\mathrm{CaO}$ & 11.59 & 12.29 & 16.04 & 8.53 & 8.48 & 8.89 & 9.13 & 2.77 & 3.18 \\
\hline $\mathrm{H}_{2} \mathrm{O}$ & 0.07 & 2.93 & 0.07 & 3.86 & 3.47 & 3.26 & 0.84 & 4.81 & 4.77 \\
\hline $\mathrm{B}_{2} \mathrm{O}$ & 1.73 & 1.12 & 0.43 & 0.74 & 1.17. & 0.45 & 0.34 & 2.27 & 3.09 \\
\hline $\mathrm{P}_{2} \mathrm{OS}_{5}$ & 0.08 & 0.09 & 0.07 & 0.29 & 0.12 & 0.19 & 0.09 & 0.10 & 0.25 \\
\hline Total & 94.70 & 97.36 & 96.11 & 96.65 & 96.81 & 100.26 & 96.76 & 95.50 & 96.40 \\
\hline $\mathrm{H}_{2} \mathrm{O}$ & 0.67 & 0.13 & 0.65 & 0.10 & 0.14 & 0.30 & 0.22 & - & 0.16 \\
\hline LOI & 3.94 & 2.19 & 3.45 & 1.54 & 1.92 & 1.62 & 4.48 & 3.50 & 3.00 \\
\hline Kg & 47.57 & 43.65 & 39.90 & 59.18 & 56.19 & 38.45 & 45.57 & 45.62 & 58.96 \\
\hline $\mathrm{Cr}$ & 443 & $\$ 01$ & 355 & $317^{\circ}$ & 264 & - & - & 52 & - \\
\hline $\mathrm{Ni}$ & 185 & 121 & 145 & 133 & 115 & - & - & 20 & - \\
\hline Co & 70 & 40 & 93 & 46 & $\cdot 38$ & - & - & 4 & - \\
\hline $\mathrm{V}$ & 231 & 148 & 173 & 166 & 136 & - & - & 50 & . \\
\hline $\mathrm{Cu}$ & 46 & 46 & 56 & 42 & 72 & - & - & 28 & -. \\
\hline $\mathrm{Pb}$ & 10 & 14 & 11 & 6 & 9 & - & - & 25 & $\therefore$ \\
\hline $\ln$ & 74 & 66 & 61 & 92 & 72 & - & - & 64 & - \\
\hline $\mathrm{s}$ & 0.01 & 0.01 & 0.01 & 0.02 & 0.02 & - & - & 0.01 & - \\
\hline 8 & 14361 & 9297 & 3570 & 6143 & 9713 & - & - & 18844 & - \\
\hline $\mathrm{Rb}$ & 2.2 & 38 & 8 & 17 & 26 & - & - & 68 & - \\
\hline $\mathrm{Ba}$ & 185 & 286 & 97 & 528 & 362 & $\therefore$ & - & 712. & - \\
\hline Sr & 1811 & 299 & 1173 & 501. & 316 & - & - & 541 & - \\
\hline Ga & 26 & .32 & 38 & 24 & 22 & - & $\therefore$ & 25 & - \\
\hline $\mathrm{Nb}$ & 9.0 & 7.0 & 2.0 & 14.0 & 10.0 & - & - & 8.0 & - \\
\hline is & 135 & 82 & 105 & 129 & 107 & - & - & 130 & - \\
\hline Ti & 7614 & 7014 & 5575 & 7374 & 4796 & - & - & 2098 & - \\
\hline$y$ & 20 & 18 & 22 & 22 & 18 & - & - & 9 & 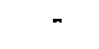 \\
\hline $\mathrm{Th}$ & - & 7.00 & - & - & - & . & - & 4.00 & - \\
\hline$v$ & - & 7.00 & $1: 00$ & 5.00 & - & - & - & 6.00 & - \\
\hline La & 2.00 & - & - & - & 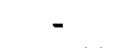 & - & - & - & \\
\hline $\mathrm{Ce}$ & 22.00 & 5.00 & 3.00 & 38.00 & 11.00 & - & - & 41.00 & - \\
\hline $\mathrm{Nd}$ & 47.00 & 24.00 & 30.00 & 52.00 & 43.00 & - & $\therefore$ & 39.00 & - \\
\hline
\end{tabular}

Tabela 06 - Análises de Rochas Metabásicas a Meta-ácidas da Sequïência VulcanoSedimentar do Rio Alegre

Observaçôes petrograficas: as amostras 15, 15A, 15B, 25, e 122 são rochas metabásicas efusivas: 27 e 126 sáo metabasitos subvulcânicoside diques; 12 e 107 sáo rochas metaacidas subvulcânicas.

Observaçðes analificas referentes às análises Nos. $15,15 \mathrm{~A}, 15 \mathrm{~B}, 25,27$ e $12: \mathrm{H}_{2} \mathrm{O}=\mathrm{H}_{2} \mathrm{O}^{-}$; LOI, conforme utilizado. inclui os teores de $\mathrm{H}_{2} \mathrm{O}$, ou seja a 'perda ao fogo' verdadeira e menor sendo LOI(real) $=\mathrm{LOI}\left(\right.$ tabela) $-\mathrm{H}_{2} \mathrm{O}$. Problemáticos sado ainda: os teores, respectivamente extremamente baixos e altos de $\mathrm{Na}_{2} \mathrm{O}$ e $\mathrm{Sr}$ das análises 15 e $15 \mathrm{~A}$, que foram considerados efeitos de !m tipo específico de alteraçá seletiva (vide texto), e os dados obtidos para os elementos terras raras: La, Ce e Nd. Na maioria das analises La e, principalmente, Ce sta nuito baixos, tanto em valores absolutos para esses tipos litologicos como em relaçăo aos teores de Nd. Esses dados, ainda que semiquantitativos, devem representar, nos casos, erros analíticos sistemáticos maiores, de calibraçăo dos elementos La e Ce. 
com as rochas ígneas basálticas a andesiticas normais e equivalentes metamórficas. São estas, notadamente, os teores muito baixos e baixos, respectivamente, de $\mathrm{Na}_{2} \mathrm{O}$ das amostras $15,15 b, 126$, com 0,07 e $0,84 \%$ de peso. Nas primeiras duas amostras considerou-se a possibilidade de tratar-se de um erro analítico, em função das observações geológico-petrográficas que revelum associaç̃̃o estreita de campo e similaridades microscópicas com a amostra 15 a (que apresenta teores normais de $\mathrm{Na}_{2} \mathrm{O}$ ). Entretanto, nota-se que, exclusivamente, estas mesmas duas amostras apresentam também teores anormalmente elevados de Estrôncio (acima de 1.100 ppm, muito além dos valores de basaltos normais). Isto tende a invalidar a hipótese de erro analitico, indicando um tipo espectfico de alteração mineralógicoaloquímica seletiva, microscópicamente ainda não identificado, diferente da epidotizaçäo comum em todas as amostras de origens extrusivas, como razăo das anomalias conjuntas de lixivią̧ão de Sódio e enriquecintento de Estrôncio.

A amostra 126, também de baixo Sódio $\left(\mathrm{Na}_{2} \mathrm{O}=0,84 \%\right)$, apresenta ao mesmo tempo os teores mais elevalos de Ferro e Magnésio (com $\mathrm{Fe}_{2} \mathrm{O}_{3 \text { (tolat }}+\mathrm{MgO}=22,85 \%$ de peso), sendo a rocha metabásica mais máfica da população analisada. Tais dados, aljados à caracteristicas petrográficas subvulcânicas, apontam para processos de cristalização fracionada e formação incipiente de cummlados máficos magmáticos.

Entre os elementos traços observam-se ainda com bastante frequêencia valores analíticos de Neodímio $>$ Cério e Neodínio $>>$ Lantanio, o que contraria a distribuição natural e abundância (absoluta e relativa) desses elementos em rochas fgneas normais (Tabela 06, ver também as tabelas $07,08,09$ e 10). Ainda que as análises dos elementos terras raras por fluorescência de raios $\mathrm{X}$ rotineira forneçam, na melhor das hipóteses, dados semiquantitativos (de orientaça), os dados obtidos devem ser considerados cono influenciados, adicionalmente, por erros analíticos sistemáticos ( sendo, no caso das rochas metabásicas em questẩo, o Cério e o Lantanio tipicamente subestimados, enquanto que o Neodímio apresenta concentrações, em geral, dentro das faixas normais, ainda que em suas partes superiores). A outra alternativa, totalmente especulativa, já que os dados não têm a precisão necessária, seria tratar-se de características geoquímicas especificas e incomuns do magmatismo e/ou das alteraçốes pósmagmáticas das rochas na área estudada.

Todas as amostras analisadas foram tratades em diagramas para identificar possiveis efeitos de alterações aloquimicas. Para tanto, os dados analiticos brutos (tabela 06) foram recalculados para $\mathrm{FeO} / \mathrm{Fe}_{2} \mathrm{O}_{3}$ utilizando uma razão de 0,83 e anidros. Esses dados foram representados nos diagranas de HUGHES (1973) e PEARCE (1982). Foram também utilizados para os cálculos 
normativos CIPW. Os dados recalculados (dos óxidos maiores) e as normas CIPW encontram-se no arexo 02 .

No diagrama de HUGHES (1973) construido com base nos alcalis principais para discriminar rochas do espectro igneo normal daquelas afetadas ou por espilitização ou por potassificação (respectivanente perda de Sodio), verificam-se as posições discrepantes em relação ao espectro ígneo normal das amostras supramencionadas 15 e $15 b$ extrusivas com teores baixissimos de $\mathrm{Na}_{2} \mathrm{O}$, da amostra 126 subvulcânica, afetada por processos cumuláticos, e a posição limítrofe no campo dos espilitos, transicionando para o espectro igneo normal das amostras de origens extrusivas 25 e 122 (Fig.08).

Já no diagrama de PEARCE (1982), baseado em elementos considerados geoquimicamente menos móveis, desenhado para distingüir composiçôes de fusôes basálticas magmáticas naturais daquelas afetadas por processos de cristalização fracionada e/ou quaisquer outros tipos de contaminação/alteração, todas as rochas metabásicas analisadas concentram-se satisfatótiamente no interior e nas imediações do campo retangular representativo das fusôes normais (Fig.09).

Esses diagramas (e todos os outros similares), deve-se ressaltar, nunca podem ser considerados tatalmente conclusivos, em funçăo da complexidade das alterações geoquímicas. Podem apenas consubstanciar os tipos de tratamentos geoquímicos escolhidos. No caso dos dados analisados, indicam a possibilidade de aplicar, com os devidos cuidados e restrições individuais, cálculos e diagramas petroquímicos de classificação $\mathrm{e}$ interpretações petrogenéticas às amostras estudadas.

Nos cálculos normativos CIPW (anexo 02) observa-se que todas as rochas metabásicas ș̃o hiperstênio-normativas, variando de quartzo a olivinanormativas, exceto uma (15a), que se apresenta insaturada, olivina e nefelinanormativa.

Os gráficos geoquímicos de classificação e geotectônicointerpretativos da população de rochas metaígneas básicas a ácidas são mostrados nas figuras 10 à 17 .

No gráfico cationico de JENSEN (1976) que distingüe os komatitos das séries toletíticas e cálcio-alcalinas, os pontos analíticos apresentam distribuiçã̃o irregular tanto nos campos das rochas toleíticas como nos campos das rochas cálcio-alcalinas. As rochas metabásicas situam-se nos campos dos toleitos, basaltos e andesitos e as rochas intermediárias a ácidas nos campos de dacitos e riolitos (Fig.10). 


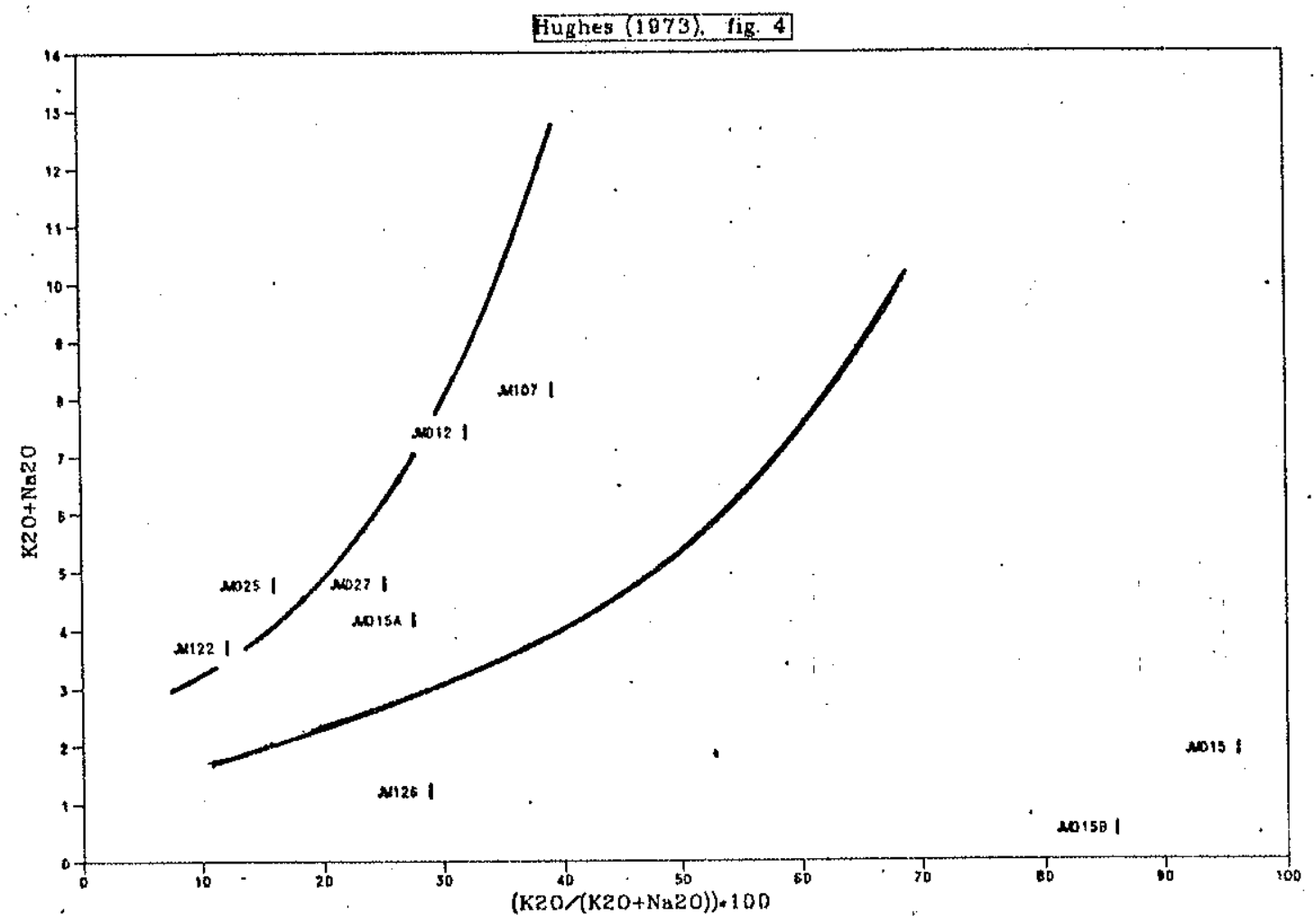

Fig. 08: Representação das rochas metabásicas a meta-ácidas da SVS do Rio Alegre em relação ao "espectro ígneo", seg. Hughes (1973).

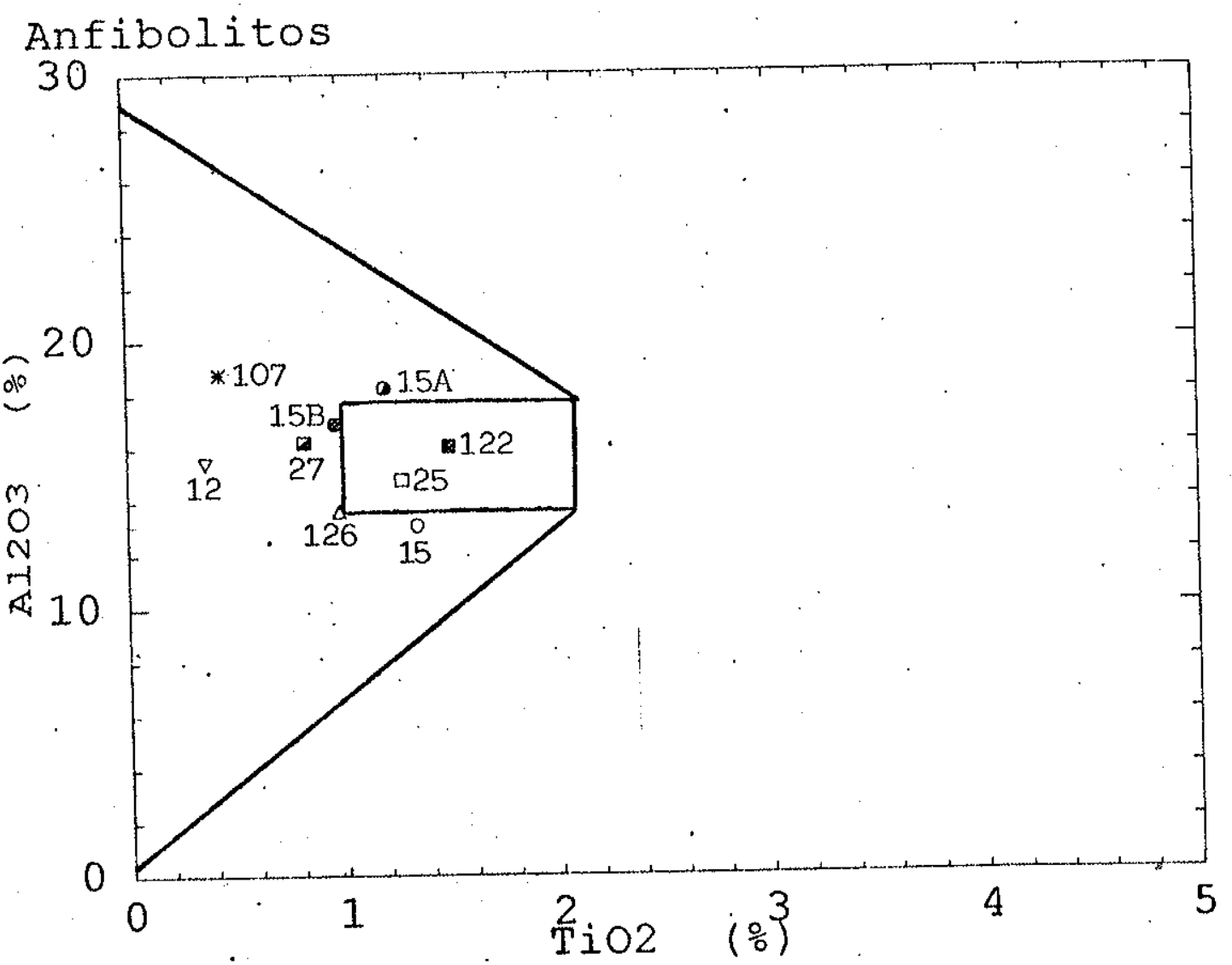

Flg. 09: Representação das rochas metabásicas a meta-ácidas da ŚVS do Rio Alegre em relação ao campo composicional (retângulo) das fusóes basálticas (fanerozóicas) naturais, seg. Pearce (1982). 


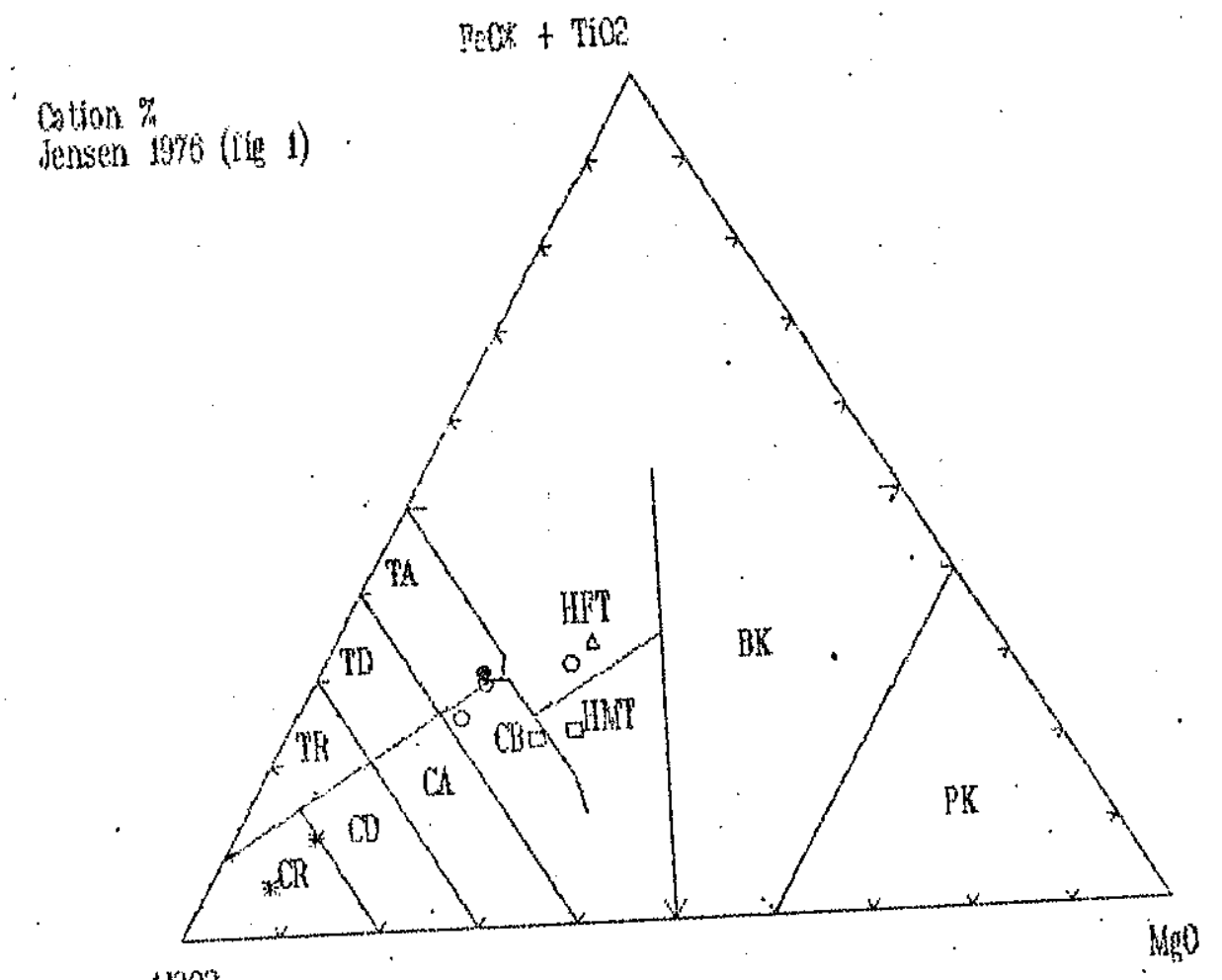

$\mathrm{ABO}$

Figura 10 - Diagrama $\mathrm{FeO}^{*}+\mathrm{TiO}_{2} \times \mathrm{Al}_{2} \mathrm{O}_{3} \times \mathrm{MgO}$ mostrando a distribuição das rochas metavulcânicas básicas e intermediárias a ácidas da Sequaência VulcanoSedimentar do Rio Alegre.

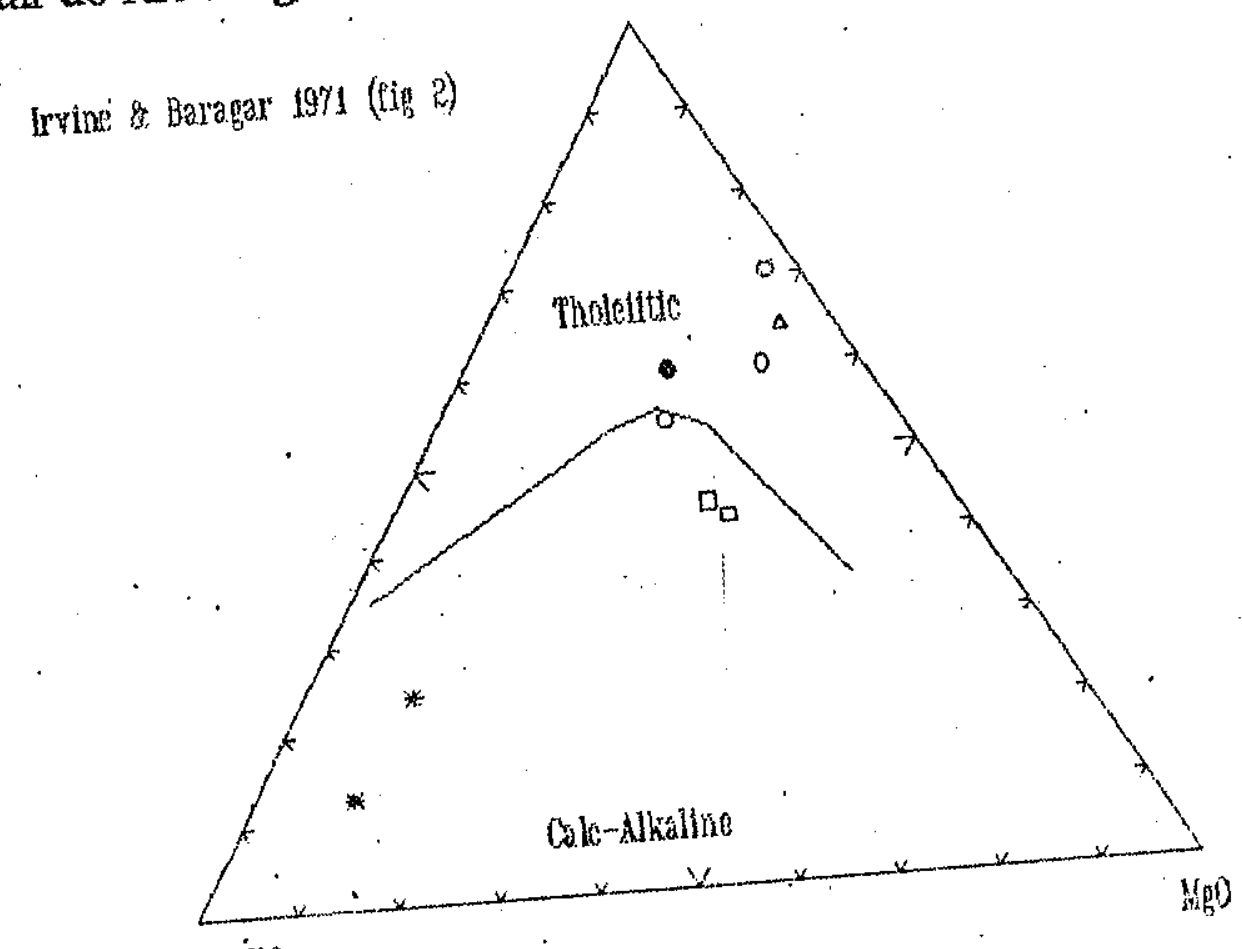

$\sqrt{12} 20+8$ Figura 11 - No diagruma AFM as rochas metavulcânicas da Seqüência Vulcano-
Sedimentar do Rio Alegre mostram distribuiça bimodal nos campos das séries toleitica e cálcio-alcalina. 
No diagrama AFM de IRVINE \& BARAGAR (1971) de distinção entre as séries toleitica e cálcio-alcalina, observa-se similarmente ao diagrama de JENSEN (1976), uma distribuição aparentemente bimodal das rochas metavulcânicas básicas nos campos toleitico e cálcio-alcalino e das intermediárias a ácidas no campo cálcio-alcalino próximo do vértice dos álcalis (Fig.11).

No grafico de IRVINE \& BARAGAR (1971) de alcalis versus $\mathrm{SiO}_{2}$, observa-se que uma distribuiçăo mais sistemática, com todas as amostras básicas a ácidas posicionadas no campo sub-alcalino (Fig.12).

Similar é a indicação do gráfico de WINCHESTER \& FLOYD (1977), onde as amostras se espalham, com apenas uma exceção, desde o campo dos basaltos, andesitos a dacitos/subalcalinos (Fig.13).

Em diagramas de elementos mais compatíveis e.g. PEARCE (1975), todas as rochas basálticas e andesiticas situam-se no campo dos basaltos de fundo oceânico, enquanto que a rocha meta-ácida apresenta caracteristicas de baixo Potássio (Fig. 14)

No diagrama de SHERVAIS (1982), a população analítica inteira de rochas básicas e intermediárias a ácidas, situa-se no campo das rochas de fundo oceânico, particularmente daquelas de bacia de retro-arco (Fig. 15).

Os dados geoquímicos de elementos compativeis e incompativeis foram tratados em variogramas muitielementares com normalização de valores de manto primitivo segundo TAYLOR \& MCLENNAN (1985), tanto as rochas metabásicas quanto as rochas intermediárias a ácidas apresentan padrões compativeis entre si, eventualmente significativos de uma fonte magmática conjunta (Figs. 16 e 17).

As rochas metabásicas (Fig.16), são caracterizadas por enriquecimentos similares e variaçós mais fortes na faixa dos elementos incompativeis. Algumas variações não-sistemáticas de enriquecimentos e empobrecimentos (ocorrem Rubídio e Bário, entre outros) e podem indicar efeitos especificos de mais forte alteração hidrotermal/metassomática nessas rochas, em relação às outras, sem evidências dessa alteração (Fig. 16). Entretanto, essas variações não são tão fortes para conferir caracteristicas de heterogeneidade ao conjunto. Os espectros são caracterizados por uma forte anomalia positiva do elemento Urânio que, para algumas amostras alteradas e não alteradas, fugiram ao padrão de enriquecimento das demais. Isto pode representar um problema analítico, já que as análises para Urânio por Fhorescência de Raios X na faixa de concentração de rochas básicas, não são precisas. Por ontro lado, o empobrecimento em Lantânio é sintomático, acompanhado dos lados mais e menos 
incompativel, respectivamente, por empobrecimentos em Nióbio e Cério. Assim, eventualmente, tais empobrecimentos são característicos desse magmatismo. 


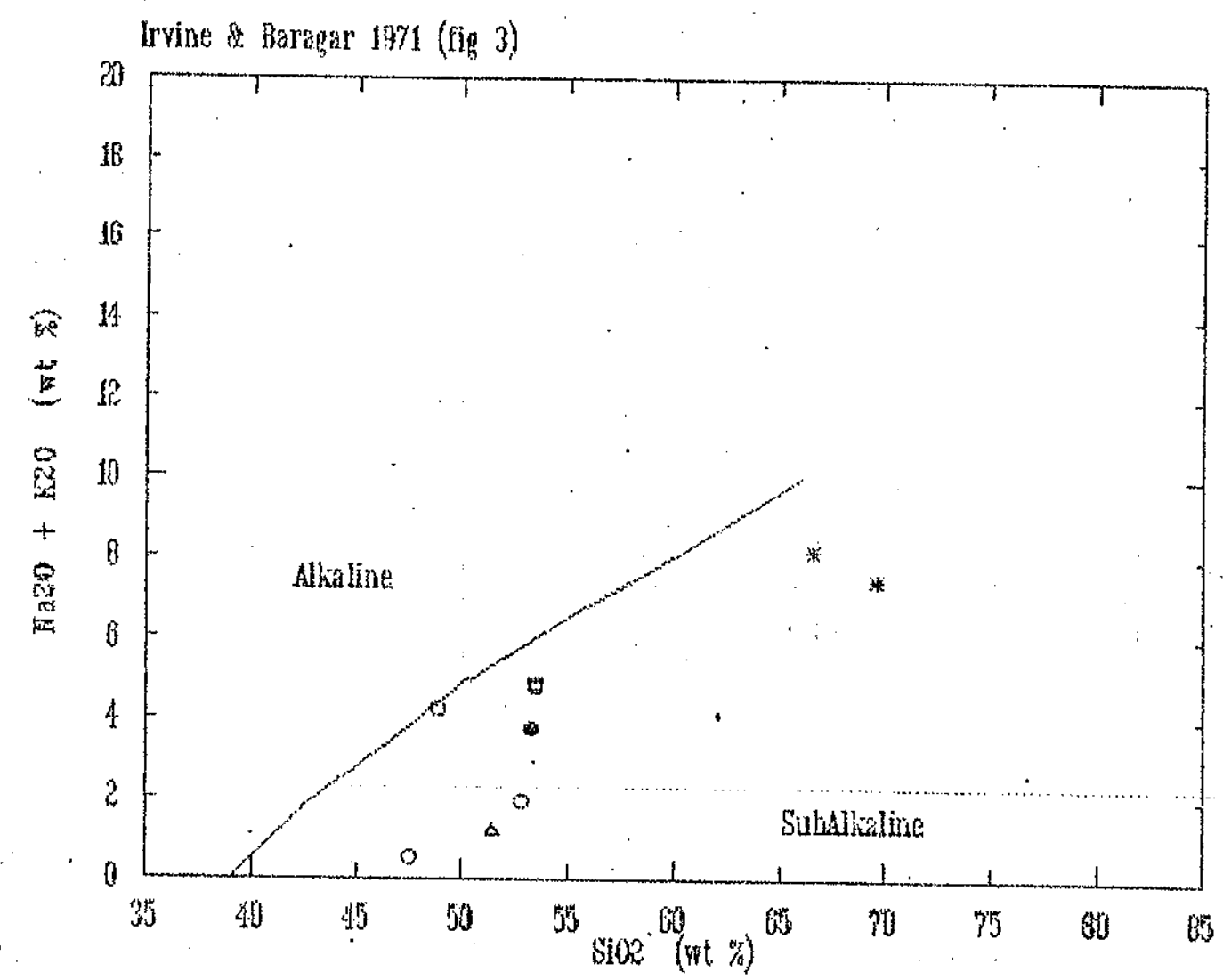

Figura 12 - $\mathrm{Na}_{2} \mathrm{O}+\mathrm{K}_{2} \mathrm{O} \times \mathrm{SiO}_{2}$ mostra a integra das rochas estudadas no campo das rochas sub-alcalinas.

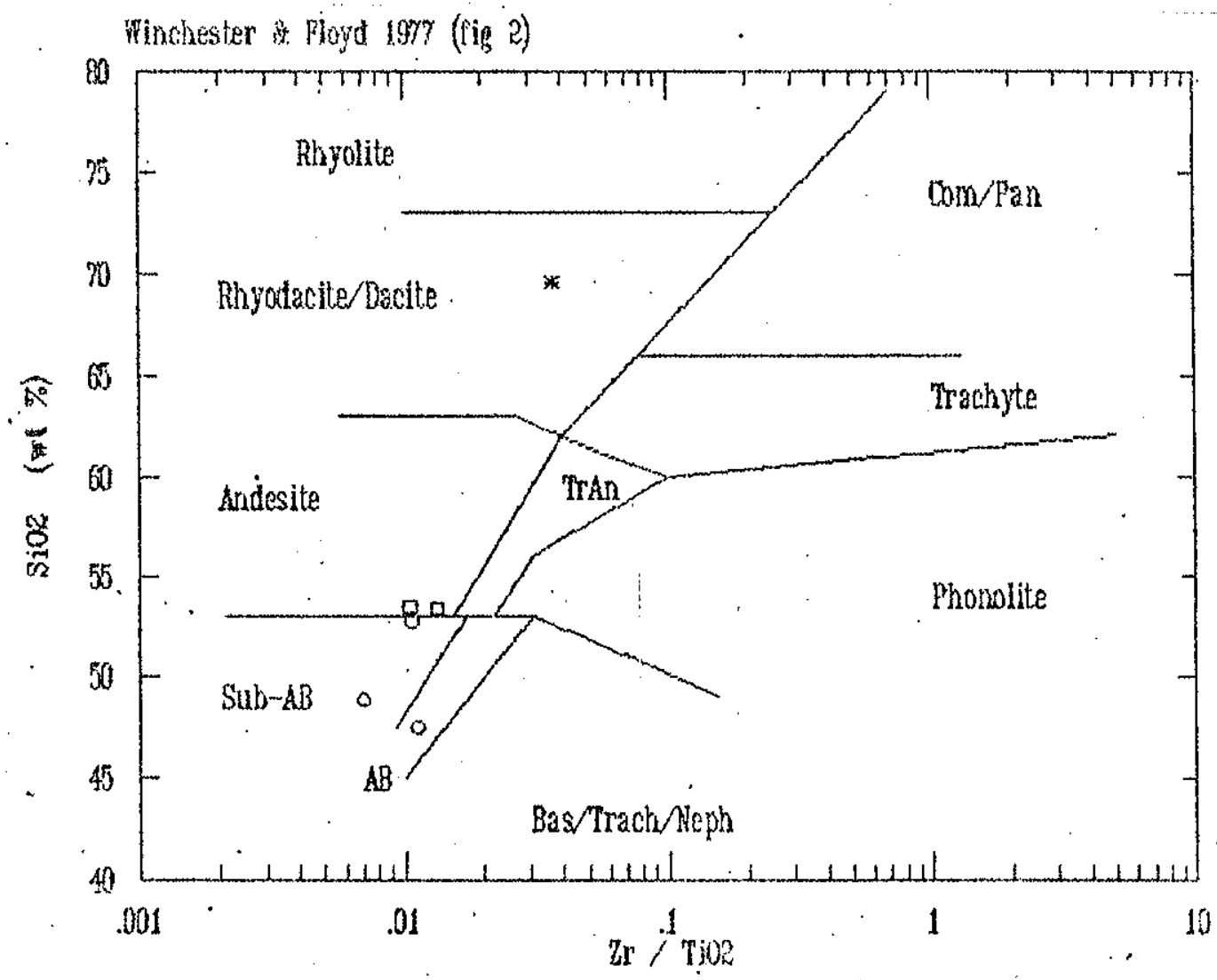

Figura 13 - O diagrama $\mathrm{Zr} / \mathrm{TiO}_{2} \mathrm{X} \mathrm{SiO}_{2}$ classifica as rochas metavulcânicas da Sequência Vulcano-Sedimentar do Rio Alegre, mostrando varią̧a desde basaltos até dacitosfriodacitos, em sua maioria absoluta sub-alcalinos. 


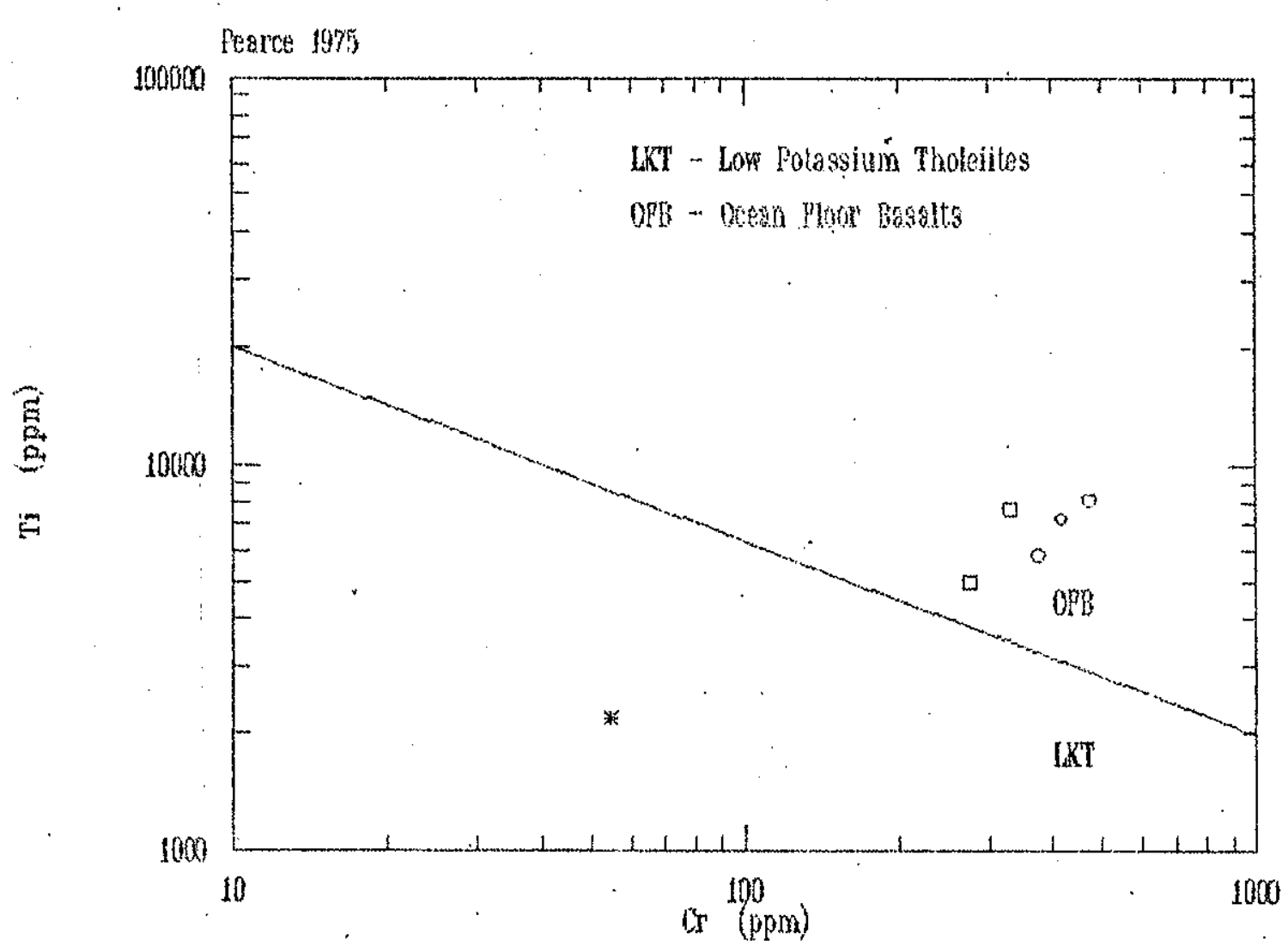

Figura 14 - Diagrama Ti X Cr a integra das rochas metabasicas no campo dos basaltos de fundo oceânico. A rocha meta-ácida apresenta caracteristicas de baixo potássio.

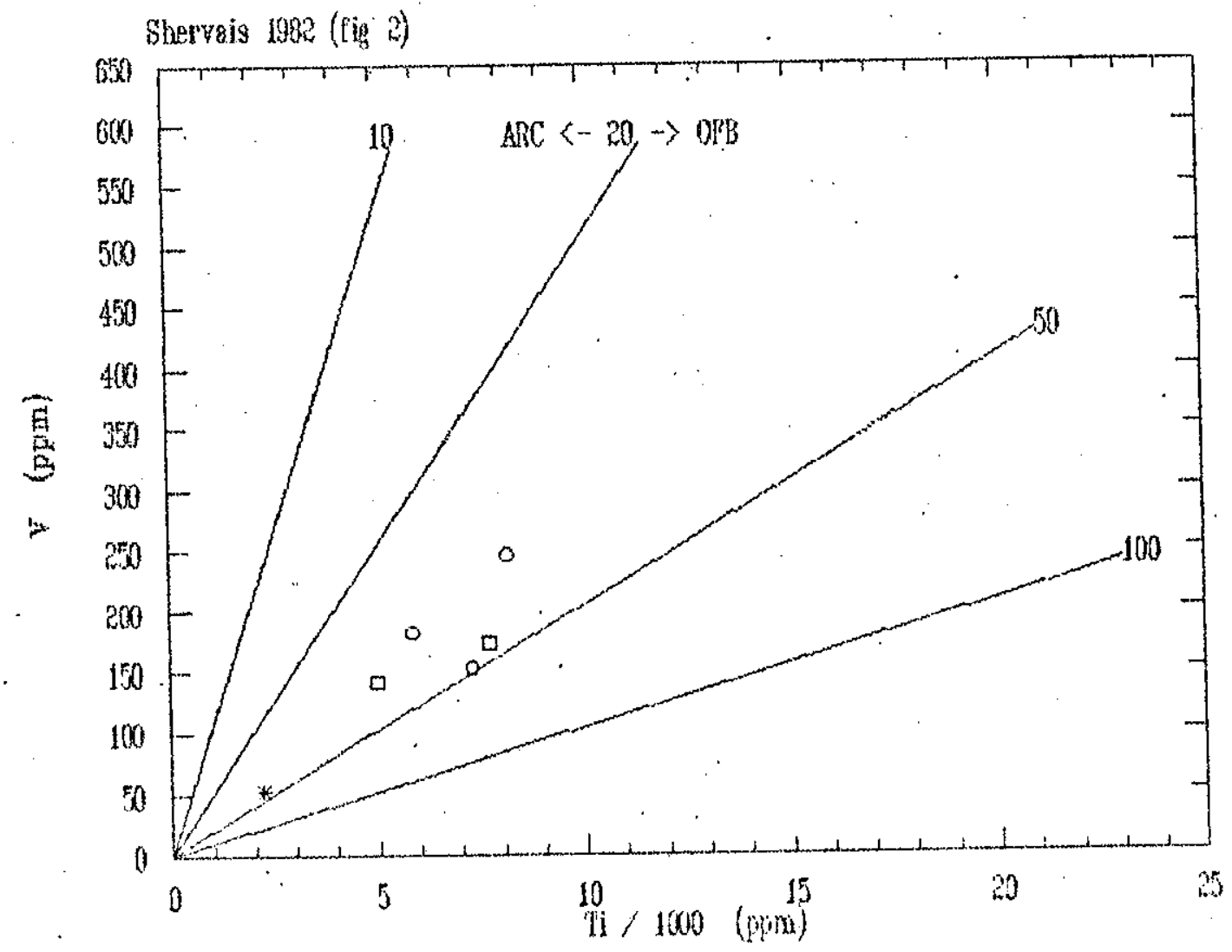

Figura 15 - Diagrama V X Ti/1000 restringe as rochas metabásicas do Rio Alegre ao campo dos basaltos de fundo oceánico formados em bacia de retro-arco. 
A rocha meta-ácida, essencialmente isenta de alterações também mostra estes empobrecimentos (Fig. 17).

O Estrôncio nas rochas metabásicas (Fig. 16), retoma os niveis de enriquecimento mostrados pelos elementos mais incompativeis, como também o Neodínio. A partir do Zircônio os elementos progressivamente menos incompativeis mostram um decréscimo linear constante até o elemento Vanádio, compativel com o que se observa em outros ambientes de seqüências vulcanosedimentares arqueanas. Há ainda leves enriquecimentos dos elementos Zinco e Cobre, de eventual significado metalogenético e fortes empobrecimentos de Níquel e Crômio, indicativos de fracionamento de olivina e espinélio/cromita durante a ascensão dos magmas mantélicos (Fig.16).

O variograma da rocha intermediária a ácida (Fig. 17) é práticamente uma réplica dos variogramas das rochas metabásicas, onde o enriquecimento dos elementos mais compatíveis foi um ponco mais forte, de acordo com a lógica dos processos de diferenciação/fracionamento magmáticos. É também caracterizado por empobrecimentos dos elementos Nióbio e principalmente Lantânio e evidentemente por empobrecimentos mais fortes dos elementos mais compativeis, com exceção do Zinco e Cobre (Fig. 17, Tabcla 06).

$\mathrm{Da}$ Seqüência Vulcano-Sedimentar do Rio Alegre, foram analisadas algumas rochas metassedimentares químicas (formaçäo ferrifera. bandada), metavulcanoclásticas (metatufos, metatufitos) e ainda rochas clásticas. Os resultados analiticos encontram-se na tabela 07.

As classificações e interpretações petrográficas das amostras da tabela 07 são as seguintes: JM-11, brecha piroclástica totalmente carbonatizada; IM13, metapelito com fraca turmalinização e eventualmente contribuição vulcânica; JM-33, metassiltito (granada-quartzo-muscovita xisto); JM-34, tufito metabásico finamente acamadado; JM-104, formação ferrifera bandada de fácies óxido, tipo quartzo-magnetita, pobre em ferro e com pequenas contribuições de fácies silicática (estilpnomelano) e carbonático ("box works" de carbonatos dissolvidos).

Apenas para fins de comparação, foram representadas as análises mais completas dessas rochas en variogramas multielementares com normalização em valores de manto primitivo (Fig. 18). Estas, apesar da diversidade das amostras, tendem a indicar uma certa regularidade dos processos geoquímicos que atuaram na formação/alteração desses litotipos, além de anomalias positivas de Cobre, de eventual importância metalogenética. Retratam ainda alguma similaridade com os gráficos análogos das rochas metavulcânicas que podem ter contribuido na formação dos metassedimentos. 


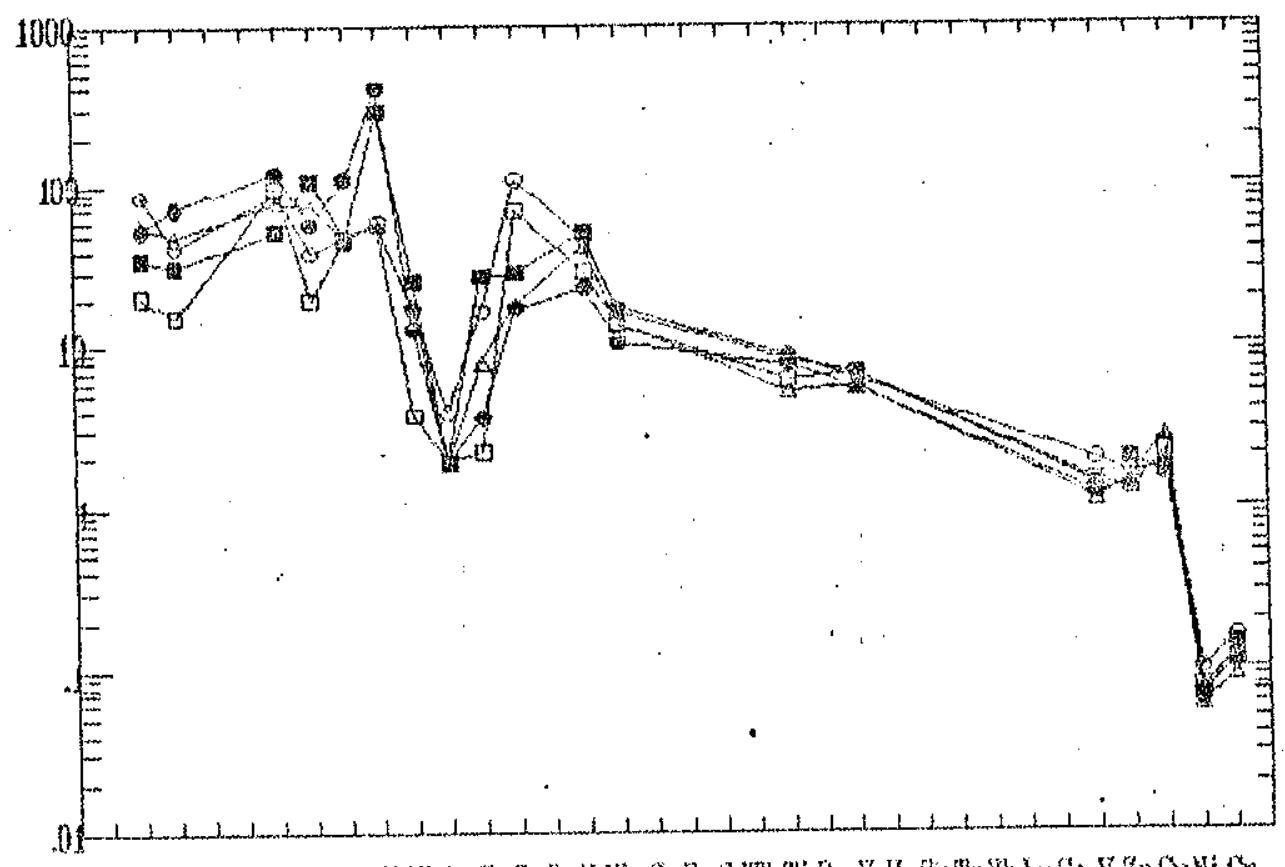

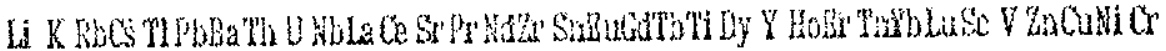

Figura 16 - Padrões de variação de elementos incompatíveis (e compatíveis) incluindo ETR, normalizados em valores de manto primitivo (Taylor \& McLennan, 1985) para as rochas metabásicas do Rio Alegre. Para as análises (Tabela 06) com valores analiticos de $\mathrm{La}(=0 \mathrm{ppm})$. Os gráficos foram construidos com o valor mínimo de $L \mathrm{a}=1 \mathrm{ppm}$.

*), Ju12

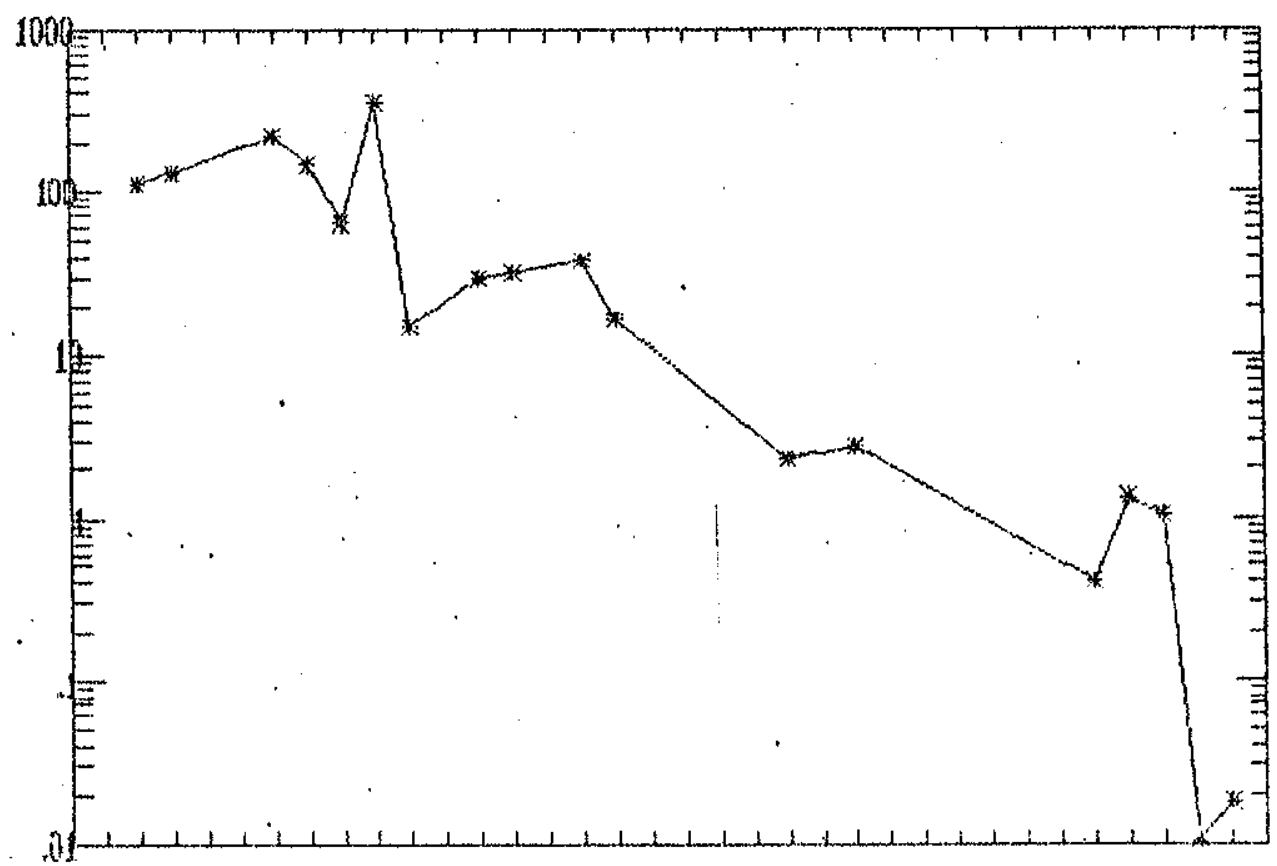

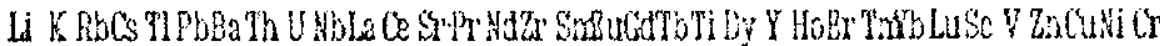

Figura 17 - Padrão de variação de elementos incompativeis (e compativeis), incluindo ETR, normalizados para valores de manto primitivo (Taylor \& McLennan, 1985), de uma rocha meta-intermediária transicional para meta-ácida do Rio Alegre. 


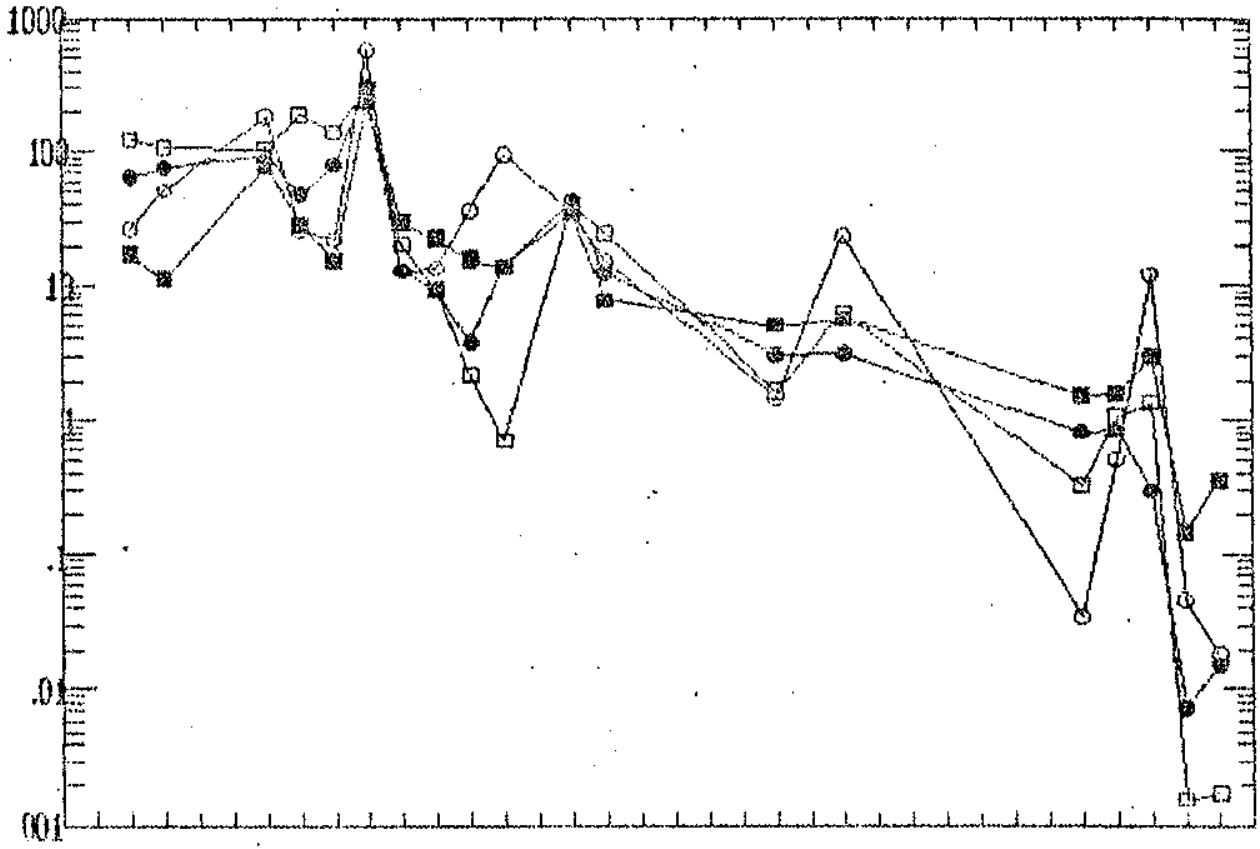

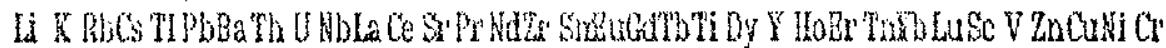

Figura 18 - Padrões de variação de elementos incompativeis (e compativeis), inchindo ETR, normalizados para valores de inanto primitivo (Taylor \& McLennan, 1985) para rochas metassedimentares clásticas, químicas (BIFs) e metavulcanoclásticas (metatufos e metatufitos) do Kio Alegre.

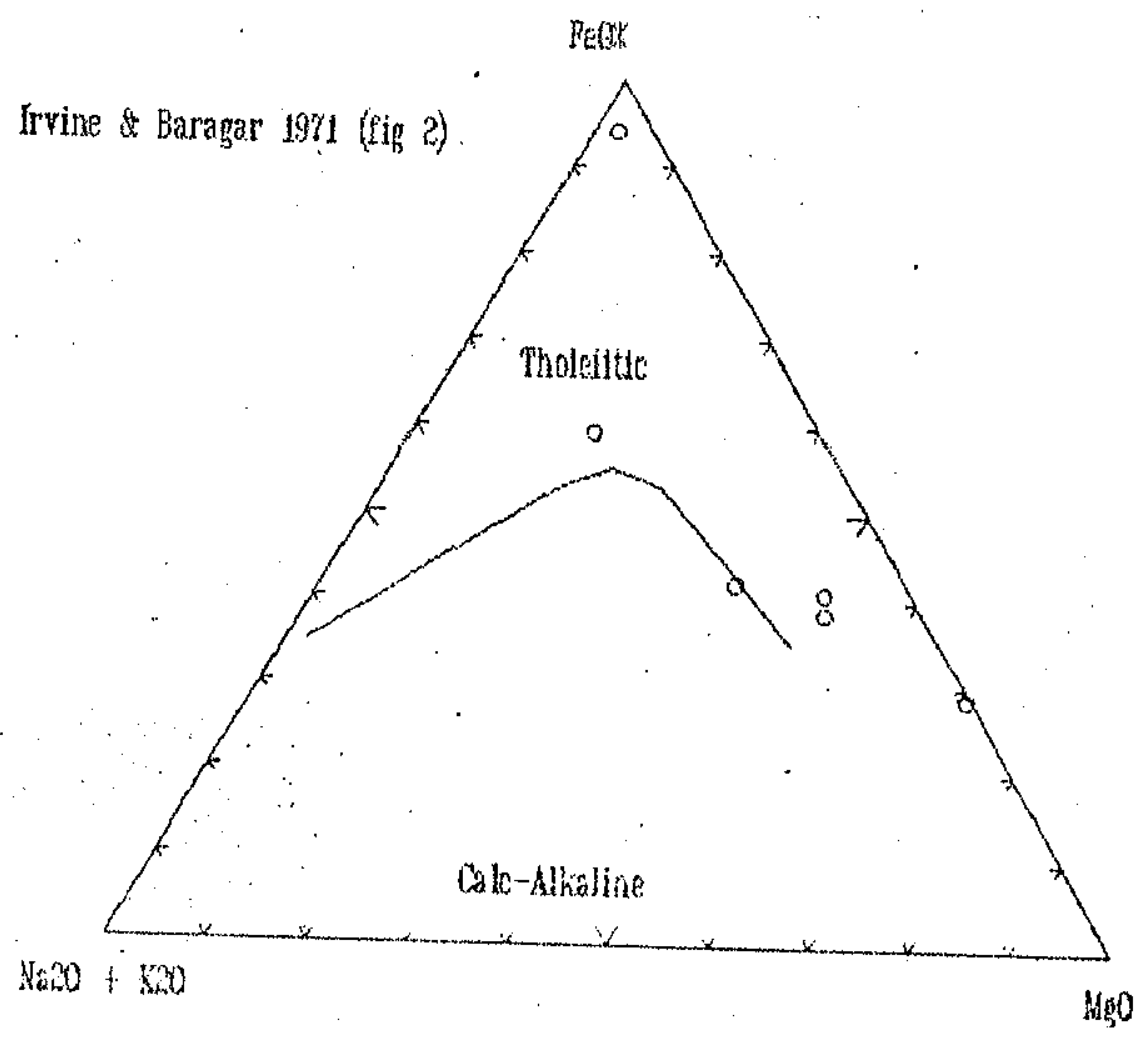

Figura 19 - No diagrama AFM, a associação de rochas intrusivas do Rio Alegre, configura um padrão de diferenciaçáo toleitico. 


\begin{tabular}{|c|c|c|c|c|c|}
\hline $\begin{array}{l}\text { Sils Nome } \\
\text { Janple }\end{array}$ & $\begin{array}{c}\text { B. QOKETSET FOO } \\
\text { JWI! }\end{array}$ & J413 & 4333 & $M 3 A$ & 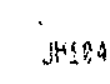 \\
\hline$E: \hat{i}_{2}$ & 95.16 & 51.32 & 74.84 & 5005 & 83.00 \\
\hline $\operatorname{Tin}_{2}$ & 4.15 & 346 & Q.5 & 9.75 & 1.83 \\
\hline A: $2: 3$ & 4.14 & 19.38 & 11.54 & 9.36 & 8.38 \\
\hline$F_{2}=3$ & $2.4 ?$ & 90.36 & 6.95 & 8.80 & 15.80 \\
\hline Hnt & 0.13 & 8.02 & 0.84 & 0.15 & 8.45 \\
\hline 690 & $1.7 !$ & 9.98 & 0.57 & 13.57 & 9.84 \\
\hline$C a C$ & 43.81 & D. AS & 0.10 & 11.93 & 0.07 \\
\hline $\mathrm{H}_{2}{ }_{2} \mathrm{I}$ & 0.05 & ล. 39 & Q.24 & 1.66 & 8.81 \\
\hline$\left[r_{B}\right]$ & 9.39 & 1.34 & 2.57 & 9.36 & 1.94 \\
\hline fans & 0.13 & 9.92 & 9.84 & 0.10 & 2.02 \\
\hline Total & 67.98 & 96.45 & 96.95 & 96.93 & 99.76 \\
\hline $\left.\mathrm{H}_{2}\right]$ & 5.47 & 0.19 & $0.29^{\circ}$ & 0.09 & 0.18 \\
\hline LOI. & 30.00 & 3.46 & 3.29 & 1.88 & 5.74 \\
\hline $\mathrm{Kg} \#$ & 57.63 & 1.44 & 14.31 & 74.91 & 0.53 \\
\hline $\mathrm{Cr}$ & 38 & 44 & 5 & 1035 & - \\
\hline $\mathrm{Ni}$ & $s e$ & 14 & 3 & 234 & - \\
\hline $\cos$ & 79 & 4 & 15 & $9 g$ & - \\
\hline V & 3 & 98 & 40 & 185 & - \\
\hline$C_{t !}$ & 230 & 8 & 36 & 78 & - \\
\hline $\mathrm{Pb}$ & 15 & 11 & 12 & 9 & - \\
\hline $2 \pi$ & 17 & 40 & 50 & 74 & - \\
\hline 3 & 0.20 & 0.01 & 0.01 & 0.01 & - \\
\hline k & 3238 & 11124 & 21334 & 2988 & - \\
\hline 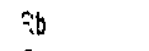 & 19 & 40 & 57 & 6 & - \\
\hline Ba & 90 & 232 & 936 & 140 & - \\
\hline $5 r$ & 1137 & 237 & $\lfloor 2$ & $\varepsilon 36$ & - \\
\hline Ga & 46 & 7 & $\therefore 14$ & 28 & - \\
\hline 蚂 & 50 & 7.9 & 11.8 & 16.8 & - \\
\hline $2 r$ & 85 & 99 & 195 & .61 & - \\
\hline $1 \mathrm{i}$ & 759 & 2758 & 1499 & 4476 & - \\
\hline 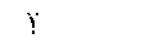 & 54 & 10 & 20 & 18 & - \\
\hline ith & 1.00 & 5.00 & 9.00 & 1.00 & - \\
\hline 4 & 7.80 & 5.00 & 5.94 & 4.00 & - \\
\hline $4 \pi$ & 50 & 5.80 & $=5.08$ & 12.80 & - \\
\hline $\mathrm{CE}$ & 35.00 & 5.00 & 3.00 & $\hat{E}^{2} .90$ & - \\
\hline $\mathrm{Nd}$ & 25.00 & 42.00 & 40.90 & 36.00 & - \\
\hline
\end{tabular}

Tabela 07 - Anábises de Rachas Metassedimentares Clásticas, Quimica (BIF) e Vulcanoclásticas da Seqüencia Vulcano-Sedimentar do Rio Alegre

Observações petrográficas: amostra 11 - metapiroclástica carbonatizada; 13, sericita xisto; 33 granada-quartzo-muscovita xisto; 34 , metatufito básico; 104, bif pobre em Fe.

Observações analíticas referentes às análises no $11,13,33$, e $34: \mathrm{H}_{2} \mathrm{O}=\mathrm{H}_{2} \mathrm{O}-;$, LOI, conforme utilizado, inclui os teores de $\mathrm{H}_{2} \mathrm{O}$, ou seja a "perda ao fogo" verdadeira e menor sendo $\mathrm{LOI}($ real $)=\mathrm{LOI}($ tabela $)-\mathrm{H}_{2} \mathrm{O}$. Os dados dos elementos $\mathrm{La}$ e $\mathrm{Ce}$ são, respectivamente, em três e duas análises, muito baixos, tanto em valores absolutos para esses litotipos como, especialmente, em relaça aos teores de Nd. Esses resiltados, ainda que semiquantitativos, devem indicar, nos casos, erros analiticos sistemáticos maiores, de calibraçäo dos elementos La e Ce. 


\section{VI.2. Complexo Gŕbrico Intrusivo}

Na parte central da área estudada (Fig. 07), ocorre um complexo intrusivo constituido de rochas de granulação grossa, onde predominam os litotipos gábricos. Ocorrem ainda tipos ultramáficos (peridotitos) e gabros mais diferenciados enriquecidos em plagioclásio e mesmo com quartzo e algum feldspato alcalino entre os produtos finais de cristalização. Seis (06) análises dessas rochas encontram-se na tabela 08 .

As normas CIPW calculadas com base na raza $\mathrm{FeO} / \mathrm{Fe}_{2} \mathrm{O}_{3}$ de 0,9 e de dados anidros, encontram-se no anexo 03.

Todas as amostras apresentam hiperstênio normativo, variando de quartzo à olivina-normativas. A grande maioria são também diopsídionormativas, exceto a amostra JM-40, de composição (mineralógica e química) peridotítica que se apresenta isenta de diopsidio e indicando traços de corindon normativo.

As análises desta associação de rochas intrusivas, representadas no diagrama AFM de IRVINE \& BARAGAR (1971), configuram bastante claramente um padrão de diferencią̧̃o toleitico. Uma amostra con ponto figurativo próximo ao vértice de FeO (JM-129) representa um metagabro cumulático muito rico em minerais opacos e afetado adicionalmete por forte epidotização (Fig. 19).

Três amostras para as quais obtiveram-se análises de elententos traços foram representadas em variogramas multielementares, com padronização em valores de manto primitivo (TAYLOR \& MCLENNAN, 1985). As amostras abrangem a faixa de rochas ultramáficas a intermediárias e correspondem en seu comportamento geoquínico, quase que de forma ideal, à modelos de diferenciação por cristalização fracionada (Fig. 20). 


\begin{tabular}{|c|c|c|c|c|c|c|}
\hline $\begin{array}{l}\text { File Nare } \\
\text { jample }\end{array}$ & 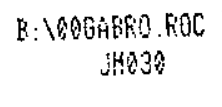 & JMO3!A & $M, 040$ & $\mathbb{M}_{1} 1 \hat{B} B$ & JHA2? & MISC \\
\hline Bif & 5316 & 30.00 & $43.3 ?$ & 52.50 & 50.90 & 46.30 \\
\hline $\mathrm{TiO}_{\alpha}$ & $\therefore .34$ & 0.93 & 9.96 & 9. $\pi^{\mathrm{n}}$ & 1.16 & $0.6 i$ \\
\hline $\mathrm{Hlal}_{3}$ & 54.37 & $\mathbb{1 1 . 0 1}$ & 8.61 & 14.50 & 16.10 & 16.30 \\
\hline$F_{2} R_{-3}$ & $\lcm{0.94}$ & 10.29 & 33.20 & 9.01 & $14 . e^{9}$ & 10.46 \\
\hline $\mathrm{M}+\mathrm{O}^{\circ}$ &.$\hat{\imath} \tilde{z}$ & 0.17 & $0.1 ?$ & 0.12 & 0.35 & 0.14 \\
\hline $\mathrm{H}_{0} \mathrm{O}$ & 347 & 12.42 & ç. $\hat{c} b$ & 7.93 & 4.34 & 11.59 \\
\hline $\cos$ & 5.28 & 9.44 & $0.3 !$ & 9.54 & 15.20 & 90.17 \\
\hline$\mu_{x_{2}}$ ? & 3.01 & 1.85 & - & 2.45 & 0.47 & 1.25 \\
\hline $\mathrm{P}_{2} 2$ & 1.41 & a. 52 & 0.01 & 0.89 & - & 0.76 \\
\hline $\begin{array}{l}\text { Ferss } \\
\text { Tota? }\end{array}$ & $\begin{array}{r}9.32 \\
95.36\end{array}$ & $\begin{array}{r}0.19 \\
96.82\end{array}$ & $\begin{array}{r}0.17 \\
87.18\end{array}$ & $\begin{array}{r}9.21 \\
97.86\end{array}$ & $\begin{array}{r}0.20 \\
98.98\end{array}$ & $\begin{array}{r}0.43 \\
98.01\end{array}$ \\
\hline $\begin{array}{l}y_{2} 3 \\
\text { LOI. }\end{array}$ & $\begin{array}{r}0.8 B \\
3.40\end{array}$ & $\begin{array}{l}0.13 \\
2.32\end{array}$ & $\begin{array}{r}0.80 \\
10.78\end{array}$ & $\begin{array}{l}0 . \hat{2} \theta \\
\hat{2} .19\end{array}$ & $\begin{array}{l}0.22 \\
1.20\end{array}$ & $\begin{array}{l}0.18 \\
2.57\end{array}$ \\
\hline $\mathrm{Kg} \mathrm{H}$ & 34.97 & 70.50 & 81.45 & 63.54 & 4.12 & 68.69 \\
\hline $\mathrm{Cr}$ & 42 & 842 & $462 t$ & - & - & - \\
\hline $\mathrm{Hi}$ & $\cdot \hat{c}^{4}$ & 319 & 1940 & - & - & - \\
\hline$C r$ & 32 & 48 & 90 & - & - & - \\
\hline 1 & 205 & 184 & 33 & - & - & - \\
\hline $\mathrm{Ol}$ & 37 & 47 & 51 & - & - & - \\
\hline 8 & 22 & 11 & 11 & - & - & - \\
\hline $2 \pi$ & $1 B A$ & 90 & 190 & - & . & - \\
\hline & & ' & & & & \\
\hline 5 & 0.02 & 0.01 & 0.01 & - & - & - \\
\hline & . & & $\cdot$ & & & \\
\hline f & 11705 & 4317 & 83 & - & - & - \\
\hline $\begin{array}{l}\mathrm{Cb} \\
\mathrm{Ba}\end{array}$ & 31 & 14 & 4 & - & - & - \\
\hline $\begin{array}{l}\mathrm{B} \\
\mathrm{si}\end{array}$ & 499 & 159 & 15 & - & $m$ & - \\
\hline $\begin{array}{l}5 r \\
67\end{array}$ & $\begin{array}{r}255 \\
26\end{array}$ & $\begin{array}{r}330 \\
23\end{array}$ & 6 & - & - & - \\
\hline 27 & $\begin{array}{l}13.9 \\
143\end{array}$ & $\begin{array}{r}\mathfrak{i n . 3} \\
\quad 82\end{array}$ & 15.8 & - & - & - \\
\hline $\mathrm{Ti}$ & $\begin{array}{r}143 \\
8033\end{array}$ & $\begin{array}{r}82 \\
5575\end{array}$ & $\begin{array}{r}7 \\
350\end{array}$ & - & - & - \\
\hline y & $\begin{array}{r}8033 \\
26\end{array}$ & $\begin{array}{r}5575 \\
24\end{array}$ & $\begin{array}{r}360 \\
8\end{array}$ & - & - & - \\
\hline Th & $\begin{array}{r}2 t \\
7.00\end{array}$ & $\tilde{\varepsilon} .0$ & $\begin{array}{r}8 \\
1.60\end{array}$ & - & - & - \\
\hline !! & $7.00^{\circ}$ & 7.04 & - & 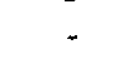 & - & - \\
\hline$L_{2}$ & 200 & - & - & - & - & \\
\hline ts & 29.00 & 21.09 & 5.80 & - & - & - \\
\hline ind & 55.00 & 33.80 & 44.60 & - & - & 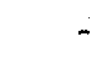 \\
\hline
\end{tabular}

Tabela 08 - Análises de Rochas do Complexo Intrusivo Metagábrico Observacóes petrográficas: amostras 30, 31a, 128, 129 e 132 -metagabros diversos; 40, metæperidotito.

Observacôes analiticas referentes as analises n conforme utilizado, inclui os teores de $\mathrm{H}_{2} \mathrm{O}$, ou seja a "perda ao fogo" verdadeira e menor sendo $\mathrm{LOI}(\mathrm{real})=\mathrm{LOI}(\mathrm{tabe} / \mathrm{a})-\mathrm{H}_{2} \mathrm{O}$. Os dados de $\mathrm{La}$ e Nd ainda que semiquantitativos, são respectivamente baixos e elevados para esses litotipos e em suas relações mútuas e devem indicar, nos casos, erros analíticos sistemáticos maiores de calibração desses elementos. 


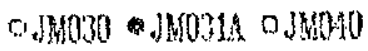

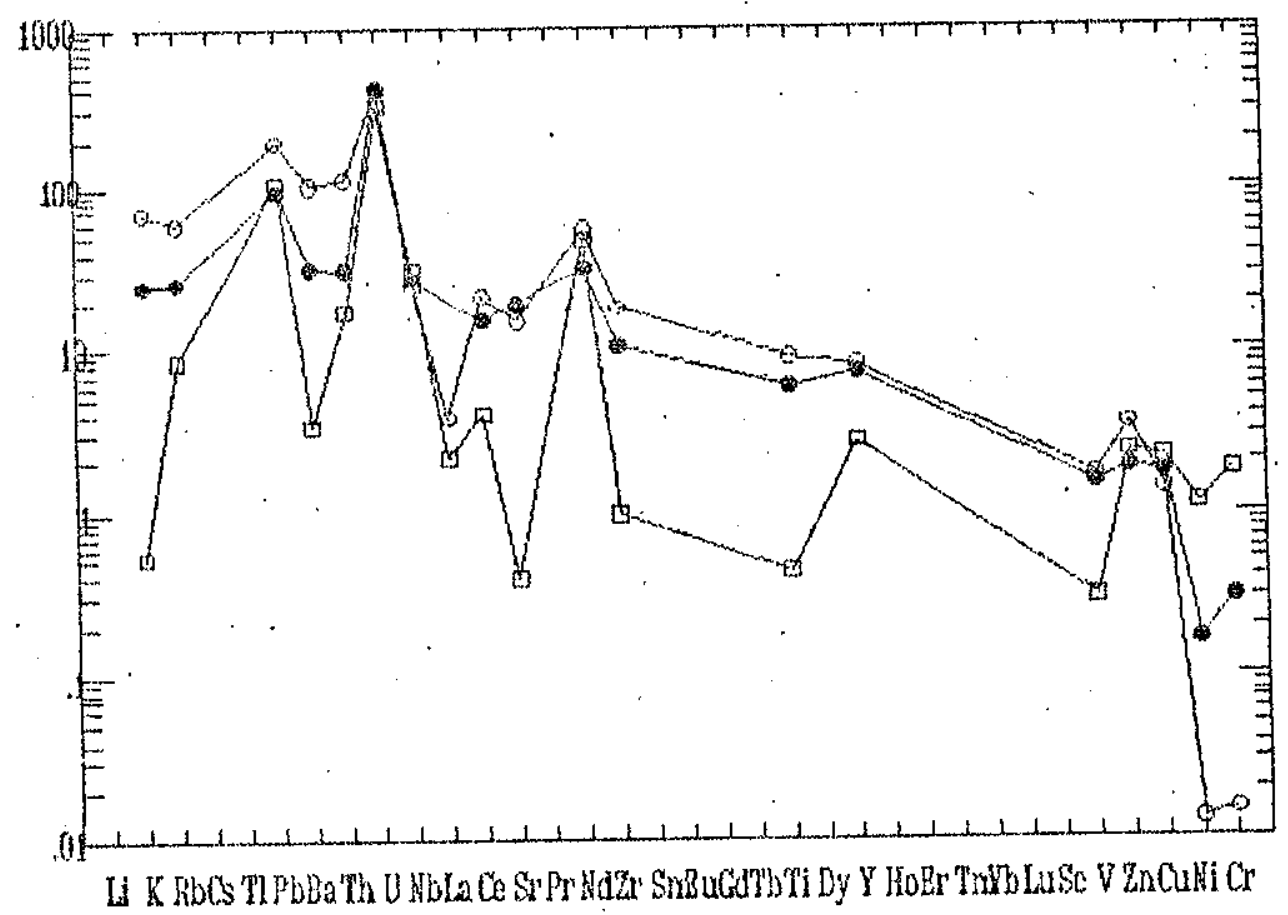

Figura 20 - Os padrões de variação de elementos incompativeis (e compativeis), incluindo ETR, normalizados em valores de manto primitivo (Taylor \& McLennan, 1985) para as rochas intrusivas gábricas e peridotítica (JM-4.0) do Rio Alegre, evidenciam comportamento compativel com os modelos de diferenciação por cristalização fracionada. 


\section{VI.3. Complexo Serpentinitico}

Na borda leste da Serra do Aguapel, ocorre um complezo de rochas serpentiniticas de granulação grossa, com texturas cumuláticas bem preservadas indicando uma origem de peridotitos intrusivos. Duas dessas amostras foram analisadas e os dados analíticos sz̃o apresentados na tabela 09 .

As nomas CIPW a partir de análises recalculadas anidras e com proporções de $\mathrm{FeO} / \mathrm{Fe}_{2} \mathrm{O}_{3}$ de 0,9 , encontram-se no anexo 04 .

As análises calculadas com os parâmetros supra-mencionados apresentam-se olivina ortopiroxênio nornativas $e$ ainda com pequenas quantidades de corindon, anortita, magnetita e cromita, entre outros minerais normativos menores (Anexo 04). Uma análise de serpentinito com dados de elementos traços (JM-39) foi comparada com a amostra JM-40, interpretada como porção ultramáfica do Complexo Gábrico, en variograma multielementar (Fig. 21). De um modo geral, os dois variogramas mostram a similaridade geoquínica intrinseca a todas as rochas ultramáficas, ainda que se constate um leve enriquecimento geral em elementos traços compatíveis e incompatíveis na amostra JM-39 do Complexo Serpentinítico, exceto para os elementos Cério e Níquel. 


\begin{tabular}{|c|c|c|}
\hline $\begin{array}{l}\text { Eise lame. } \\
\text { Sample }\end{array}$ & 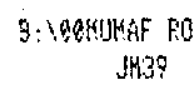 & JMiget \\
\hline Side & 20.14 & $33.7 \%$ \\
\hline Tife & 3.12 & 0.35 \\
\hline$f_{1} i_{2} L_{3}$ & 1.73 & $2.7^{\mathrm{s}}$ \\
\hline$F_{f} \ell_{3}$ & 12.55 & 16.79 \\
\hline $\operatorname{Hin} ?$ & 0.20 & Q. 20 \\
\hline Kag & 33.01 & $\hat{\varepsilon} 9.4 \hat{E}$ \\
\hline $\mathrm{CaO}$ & 0.10 & 1.10 \\
\hline $\mathrm{N}_{2} \mathrm{2}$ & - & 0.05 \\
\hline$\left[\mathrm{r}^{3} \mathrm{Z}\right.$ & 0.03 & 0.02 \\
\hline $\mathrm{Fel}_{3}$ & 0.4 & 0.01 \\
\hline Total & 87.92 & 89.30 \\
\hline $\mathrm{H}_{2} \mathrm{i}$ & 0.35 & 107 \\
\hline LOI & 11.35 & 10.08 \\
\hline 498 & 83.89 & .77 .63 \\
\hline $\mathrm{Cr}$ & 4993 & - \\
\hline $\mathrm{Hi}$ & 1038 & - \\
\hline Co & . $\quad 89$. & - \\
\hline$v$ & 53 & - \\
\hline Cu & 219 & - \\
\hline $\mathrm{Fb}$ & IE & - \\
\hline $2 n$ & . $\quad 180$ & - \\
\hline & & . \\
\hline 3 & 0.01 & - \\
\hline p. & 249 & - \\
\hline 3 & 7 & - \\
\hline $6 e$ & 1 & - \\
\hline 约 & 19.0 & - \\
\hline at & 11 & - \\
\hline $\mathrm{Ti}$ & 719 & - \\
\hline$y$ & 10 & - \\
\hline$y$ & 5.00 & - \\
\hline $\mathrm{CE}$ & 300 & - \\
\hline Nd & $4 \hat{c} .00$ & - \\
\hline
\end{tabular}

\section{Tabela 09 - Análise de Metaperidotitos}

Observações petrográticas: metaperidotitos cumuláticos

Observacôes analiticas referentes à análise no $\mathrm{n}^{\circ}$ 39: $\mathrm{H}_{2} \mathrm{O}=\mathrm{H}_{2} \mathrm{O}-\mathrm{LOI}$, conforme utilizado, inclui os teores de $\mathrm{H}_{2} \mathrm{O}$, ou seja, a "perda ao fogo" verdadeira e menor sendo LOI(rea) $-\mathrm{LO}($ trbela $)-\mathrm{H}_{2} \mathrm{O}$. $\mathrm{O}$ dado de $\mathrm{Nd}$, ainda que semiquantitativo, é muito elevado para esse tipo litológico e em suas relaçöes com Ce e La $(=0)$ indicando, no caso, erros analíticos sistemáticos maiores de calibração desses elementos. 


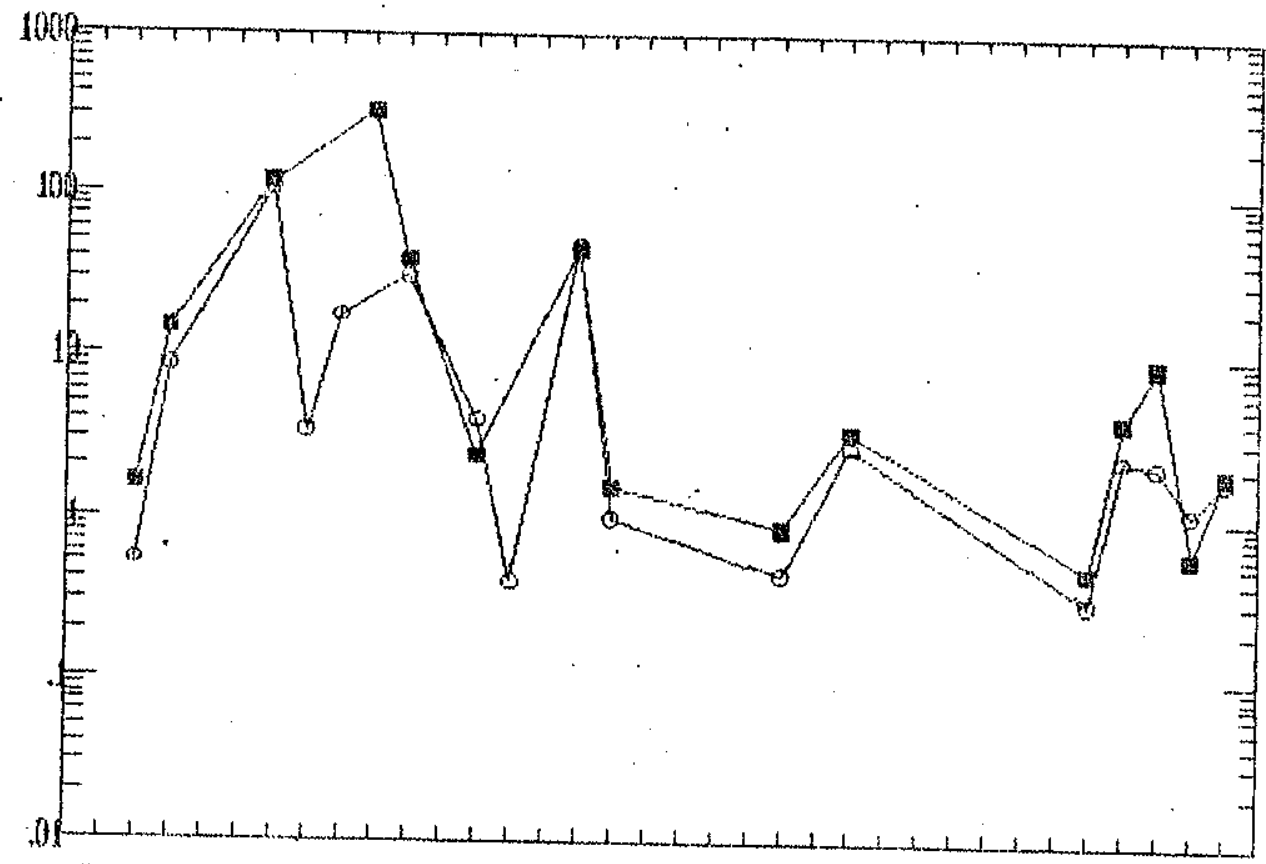

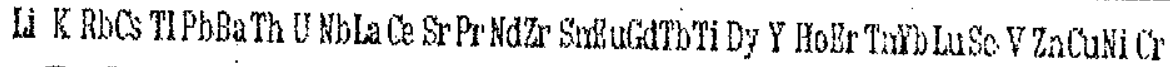

Figura 21 - Padrão de variação dos elementos incompativeis (e compatveis) incluindo ETR, normalizados em valores de manto primitivo (Taylor \& McLennan, 1985) de um serpentinito da parte leste da área estudada (JM-39), mostrando similaridade geoquímica ao padrão apresentado por um metaperidotito do Complexo Gábrico (JM-40) representado na Figura 20.

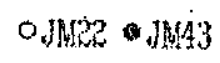

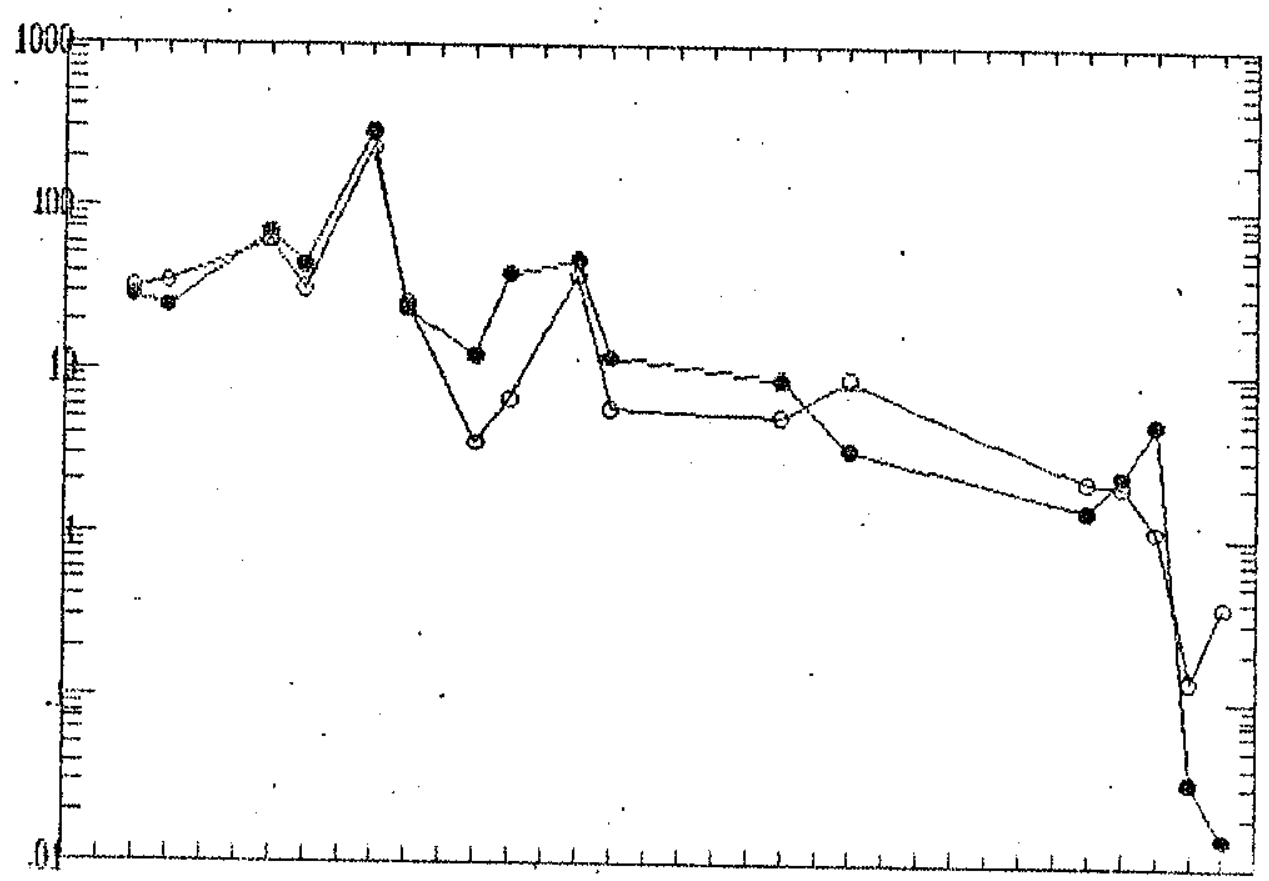

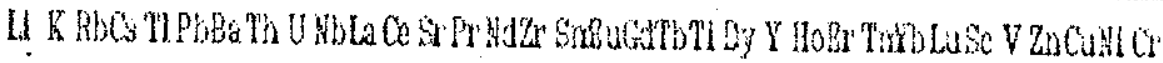

Figura 22 - Os padrões de variação de elementos incompatíveis (e compatíveis) incluindo ETR, nomalizados para valores de manto primitivo (Taylor \& McLennan, 1985) de dois diques máficos do Rio Alegre, evidenciam quimismo mais evoluido no dique de tendências alcalinas. 


\section{VI.4. Diques Metabásicos}

Diques metabásicos cortam a sequüencia Vulcano-Sedimentar do Rio Alegre na parte central da área e também o Complexo Serpentinitico à leste da Serra Salto do Aguapeí. Três amostras foram analisadas, sendo duas de diques que cortam a sequência vulcano-sedimentar e uma associada a Complexo Serpentinítico. Os dados analíticos são mostrados na tabela 10.

As análises recalculadas atidras, com razäo $\mathrm{FeO} / \mathrm{Fe}_{2} \mathrm{O}_{3}$ de 0,83 foram utilizadas para calcular as normas CIPW (Anexo 05).

As análises de diques que cortan a seqüencia vulcanosedimentar (JM-22 e 102 são hiperstênio normativas, variando de quartzo a olivina normativas, enquanto que o metabasito associado ao serpentinito da parte leste da área (JM-43) apresenta-se com uma norma de alcali-olivina basalto, com alguma nefelina.

Duas amostras com dados analíticos de elementos traços foram representados em variogramas multielementares e constituem a figura 22 . A amostra JM-22 é hiperstênio-olivina normativa (dique intrusivo na sequiência vulcano-sedimentar), enquanto que a amostra JM-43 é olivina-diopsidio-nefelina normativa, representativa do dique associado ao serpentinito. No dique de tendências alcalinas, fica claro um padrão geoquimico mais evoluido em relaçăo ao padrão mais primitivo da rocha toleiitica 


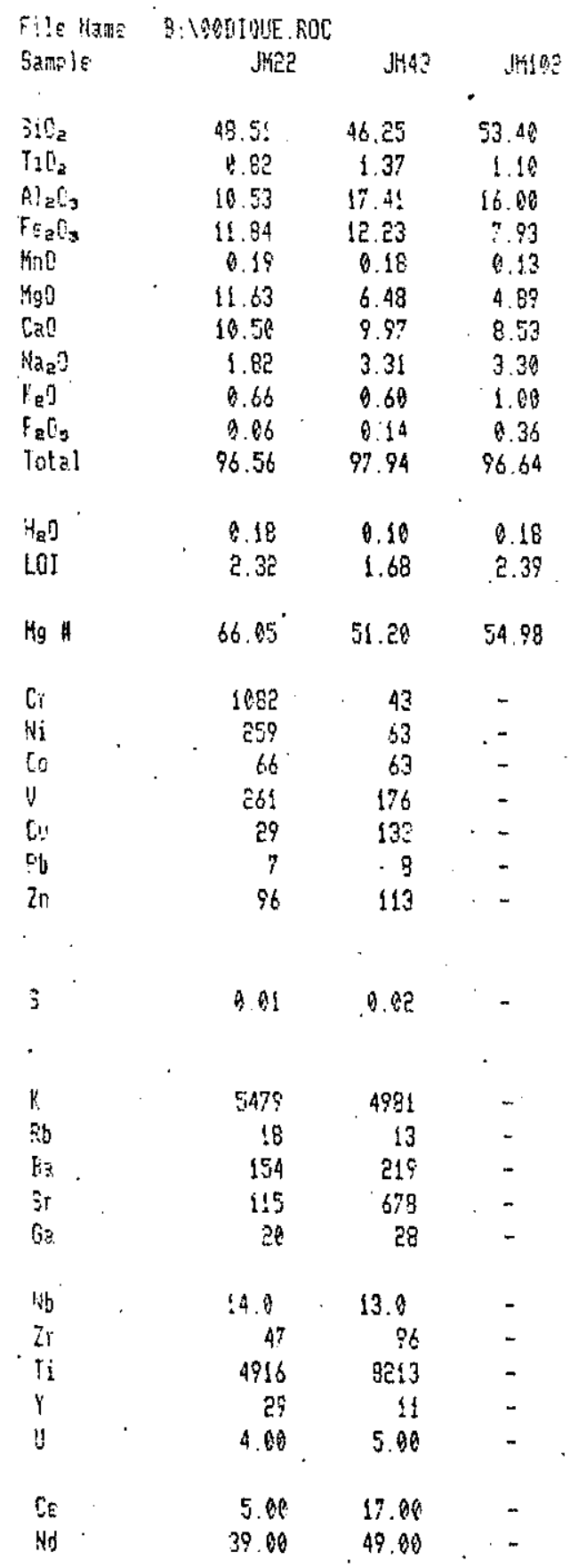

Tabela 10 - Análises de Diques Metabásicos

Observacões petrográficas: amostras 22 e 102: são de diques que cortam a S.V.S. do Rio Alegre. A amostra 43 é de un dique que corta o serpentinito da parte leste da área.

Observações analíticas referentes às análises nog 22 e $43: \mathrm{H}_{2} \mathrm{O}=\mathrm{H}_{2} \mathrm{O}-; \mathrm{LOI}$, conforme utilizado, inclui os teores de $\mathrm{H}_{3} \mathrm{O}$, ou seja, a "perda ao fogo" verdadeira e menor, sendo LOI(real $)=\mathrm{LOI}\left(\right.$ tabela)- $\mathrm{H}_{2} \mathrm{O}$. Os dados de $\mathrm{La}(=0)$ e Ce, em geral e em relação ao Nd, ainda que semiquantitativos, são muito baixos para esses tipos litológicos e devem indicar, nos casos, erros analiticos sistemáticos maiores de calibraçäo desses elementos terras raras. 


\section{CAPITULO VII}

\section{CONCLUSOKES}

1) Geologicamente, a regiăo do Rio Alegre possui características de terrenos arqueanos, com retrabalhamentos proterozóicos superimpostos, similares a outras áreas da borda do Cráton Amazônico e/on, em geral, de núcleos continentais arqueanos, com acréscimos crustais proterozóicos de outras regióes do Brasil e do mundo (Quadrilátero Ferrifero.MG, África do Sul, Austrália e Canadá, entre outras).

2) Os tipos de associaçóes lito-estruturais arqueanas compreendem gnaisses, migmatitos e granitóides intrusivos diversos, do Complexo Metamórfico do Alto Guaporé. Parte dos gnaisses e migmatitos observados na área de estudo, apresentam características petrográficas de complexos de gnaisses TTG (gnaisses tonalito-trondhjemito-granodioriticos) arqueanos, onde os litotipos mais aluminosos (eventualmente granatiferos) e os metaluminosos (com hornblenda), poderiam representar, respectivamente, associações TTG com alto e baixo ahumínio, no sentido de CONDIE (1981).

3) Balizados por contatos tectônicos a oeste pelos gnaisses do Complexo Metamórfico do Alto Guaporé e a leste ora pelos metassedimentos do Grupo Aguapei, ora pelo Granito Santa Helena, ocorre a Sequência VulcanoSedimentar do Rio Alegre. Para esta, foi proposta, com base em critérios de campo, petrográficos e geoquímicos, uma origem como cinturão de rochas verdes ("greenstone belt") arqueanas e a seguinte subdivisão lito-estratigráfica:

a) Formaça Minouro, composta por vulcanitos e subvulcanitos básicos tais como: basaltos e diabásios extrusivos e intrusivos, anfibolitizados por metanorfismo regional de baixo grau.

b) Formaçao Santa Isabel, constituída por lavas e tufos de composição dacítica a riodacítica e ainda por pequenos corpos intrusivos de mesma camposição.

c) Formasao Sao Fabiano, caracterizada por rochas metassedimentares clásticas e químicas, incluindo os seguintes litotipos: sericita xistos às vezes 
granatiferos e com teores variáveis de biotita, xistos grauváquicos finos, metacherts e formaçóes ferriferas bandadas de fácies óxido com magnetita. Subordinadamente ocorrem fácies carbonático, silicático (com estilpnomelano) e sulfeto (pirita), no sentido de MATOS \& RUIZ $(1990,1991)$. Esta unidade compreende ainda metassedimentos vulcanoclásticos, tufos e tufitos, representados por clorita xistos e clorita-anfibólio-quartzo xistos, com magnetita e pirita. Geoquimicamente, esta unidade apresenta anomalias de Ouro e Cobre, ligadas tanto às formaçôes ferriferas como às rochas mulcanoclásticas, que foram alvos de estudos pela Companhia Matogrossense de Mineração-METAMAT (NEDER et al. 1984). Vale ressaltar que na continuação desta unidade para norte da área estudada, operam garimpos e também empresas industriais, através da mineração Santa Elina e Lavrinha (Giupo Paulo Abib), com considerável produção de ouro.

4) Os basaltos da Formação Minouro evidenciam alterações mineralógicas sugestivas de processos aloquímicos hidrotermais/netassomáticos, pré-metamórficos. Estas aiterações, predominantemente do tipo epidotização, espilitização e subordinadamente carbonatação e sericitização, foram interpretadas como alterações do tipo fundo oceânico, em sistema de atividade hidrotermal. Ocorrem ainda alteraçôes posteriores, metamórficas, na fácies dos xistos verdes; que dificultam sobremaneira o tratamento dos dados geoquímicos e suas interpretações petrogenéticas. Ainda assim, alguns dos diagramas geoquímicos utilizados, principalmente àqueles fundanentados em elementos mais compativeis (por exemplo SHERVAIS, 1982), sustentam uma origem do tipo assoalho oceânico, eventualmente em bacia de retro-arco. Entretanto, a variabilidade dos (ainda escassos) dados é elevada e nem sempre sisternática, principalmente para os elementos incompativeis. Os metabasitos da Formação Minouro e principalmente dqueles mais fortemente afetados por processos hidrotermais/metassomáticos prémetamórficos, evidenciam anomalias geoquimicas de Cobre e Zinco, indicando um potencial metalogenético desses metais, associados a esta unidade.

5) As rochas meta-intermediárias transicionais para meta-ácidas da Formação Santa Isabel foram tratadas geoquimicamente em conjunto com os métabasitos da Formação Minouro. Estas rochas também sofreram alterações prémetamórficas/aloquímicas, principalmente de fraca sericitização e carbonatação. Em diagramas de elementos compativeis, figuram em conjunto com os metabasitos na associação de fundo oceânico do tipo bacia de retro-arco.

6) O metamorfismo regional que afetou a Sequência VulcanoSedimentar do Rio Alegre e retrometamorfizon os gnaisses do Complexo Metamórfico do Alto Guaporé foi de fácies xisto verde médio a superior, provavelmente com caracteristicas barrovianas. A idade deste metamorfismo 
regional principal é proterozóica (pós-Aguapei), ainda não definitivamente estabelecida. Com base no estado de defornação, admitem-se condições polimetamórficas para as rochas da Seçüência Vulcano-Sedimentar do Rio Alegre, ou seja, que ela tenha sofrido pelo menos uma fase de metamorfismo de fácies xisto verde mais fraca, ainda em periodo tardi a pós-Arqueana, anteriormente ao metamorfismo regional principal.

7) Ocorre na região estudada, um Complexo Gábrico considerado de origem intrusiva, apesar dos contatos tectônicos. É composto por rochas de granulação grossa e compreende litotipos que indicam diferenciação "in. situ", com membros desde peridotitico-harzburgítico ultramáficos a gábricos e de leuco-gabros como termos mais diferenciados. Esse complexo apresenta evolução/diferenciação toleiitica. Notáveis são algumas rochas ricas em minerais opacos, inchuindo sulfetos dessa associação que também apresenta anomalia geoquímica de Cobre e Zinco e subordinadamente de Crômio e Níquel. Complexo Gábrico também foi afetado pelo principal metamorfismo regional pósAguapei, em condições de fácies xisto verde médio a superior.

8) $\mathrm{Na}$ parte leste da área, ocorre um corpo de rochas metaultramáficas transformadas en serpentinitos, sem perder as texturas magmáticas originais. Trata-se de peridotitos, dunitos, harzburgitos, com texturas cumuláticas de granulação grossa. Cromita acessória e olivina representam as fases cumulus e principalmente orto e clinopiroxênio as fases intercumulus. Neste caso, os clinopiroxênios (cálcicos), foram preservados dos efeitos do metamorfismo regional. Estas rochas apresentam enriquecimentos característicos de Crômio e Níquel e ainda anomalias positivas de Cobre e Zinco. Suas relações com o Complexo Gábrico, do qual poderia ser uma parte, não são conhecidaș.

9) A parte leste da área é ocupada pelo Granito-Gnaisse Santa Helena, de natureza intrusiva, porém apresentando contatos tectônicos com as demais unidades geológicas da região. Na área estudada, apresenta-se bastante homogêneo, com composiç̃̃o de granito $3 \mathrm{~b}$. Dados radiométricos publicados, de contimuações do corpo além da area deste estudo, indicam idade do Proterozóico Médio. Esse corpo também foi afetado pelo principal evento regional pós-Aguapeí, de fácies xisto verde.

10) O. Grupo Aguapeí ocorre típicamente na Serra Salto do Aguapeí e eventualmente em algumas unidades menores na parte centro-leste da área estudada, mostrando direção geral $N$-NW e caimento para oeste. É constituido por rochas quartzíticas e localmente metaconglomerados, com mineralizações de ouro do tipo paleo-placer. Estas, são alvos de pequenas exploraçóes do tipo garimpo. As idades de sedimentação e metamorfismo desta unidade ainda nỗo 
foram definitivamente estabelecidas. De um modo geral, são as rochas préCambrianas mais jovens desta área de pesquisa e as idades geológicas e radiométricas a elas atribuidas são do Proterozóico Médio a Superior. 
ALMEIDA, F.F.M. de; - 1964 - Geologia do Centro-Oeste Matogrossense. DGM/ DNPM. Bol. 241. Rio de Janeiro. $36 \mathrm{p}$.

ALMEIDA, F.F.M. de; - 1978 - A evolução dos Cratons Amazinnico e do Sấo Francisco, comparada com seus homólogos do hemisferio norte. In: CONGR. BRAS. GEOL. 30 - Recife. 1978. 6: 2393-2407.

AMARAL, G. - 1974 - Geologia Pré-Cambriana da Região Amazônica. São Paulo IG-USP. Tese de Livre Docência 212 p. (inédito).

BARD, J.P. - 1980 - Microtextures of Igneous and Melamorphic Rocks. Transl. by Mariame Mareschal. Ed. by S.W. Morel. D. Reidel Publ. Co. Dordrecht, Holland. $264 \mathrm{p}$.

BARROS, A.M; SILVA, R.H. da; CARDOSO, O.R.F.A; FREIRE, F.A; SOUZA JÚNIOR, J. J. da; RIVETTI, M.; LUZ, D. S. da; PALMEIRA, R. C. de B; TASSINARI, C.C.G. - 1982 - Geologia. In: Brasil MME/SG. Projeto RADAMBRASIL. Folha SD-21 Cuiabá. Rio de Janeiro. (Levantamento de Recursos Naturais). 26: 25-192.

BARROW, A - 1912 - On the Geology of Lower Dee-side and the southern Highland Border. Proc. Geol. Ass., 23: 274-290.

CARDOSO, O.R.F.A.; DELARCO, I.O. \& SOUZA, E.P. de; - 1980 - Reconhecimento geolbgico em parte das follhas SD-20-2-D e SD-21-Y-C;Operação 541/79. Goiânia. Projeto RADAMBRASIL. (Relatório Intenno 386-G). 6lp. CARNEIRO, M.A - 1985 - Contributção d̀ Geologia da Região de São José dos Quatro Marcos - MT. São Paulo. IG-USP. Dissertação de Mestrado, 156 p. (Inédito).

CARNEIRO, M.A. - 1989 - Petrografy and Geochronology of Anfibolitic rocks in the Sao Jose dos Quatro Marcos Area, southwestern Mato Grosso, Brasil. Bol. IG-USP, Série Cient. 20: 47-56.

CHAYES, F. - 1949 - A simple counter for thin section analysis. Am. Min., 134: $1-11$.

CLARKE, D. - 1990, 1992 - Newpet. Version 7.0. Memorial University of Newfoundland. Department of Earth Sciences. Centre for Earth Resources Research. Copyright Microsoft Corporation.

CONDIE, K.C. - 1981 - Archean Greenstone Belts. Elsevier Sci. Publ. Amsterdan. New. York. 434 p. 
CORDANI, U.G. - 1981 - Evolución Tectônica de la Corteza Continental de Sudamérica y su imporiancia en la caracterizacion de Provinctas Uranfferas. In: Uranium Deposits in Latin América Geology and Exploration. Tech. Lett. Atom. En. Agency. Viena. p. 3-23.

CORDANI, U.G. \& BRITO NEVES, B.B. de; - 1982 - The evolution of Sowh Americo during the Archean and Early Proterozoic. In: Intern. Symp. Arch. and Early Prot. - Geologic Evolution and Metallogenesis. Salvador BA. Rev. Bras. Geoc. 12: 78-88.

CORDANI, U.G.; TASSINARI, C.C.G.; TEIXEIRA, W.; BASEI, M.A.S.; KA. WASHITA, K. - 1979 - Evoluça Tecionica da Amazonia com base nos dados Geocronoldgicos. In: CONGR. GEOL. CHILENO 2. Arica. Chile. 1979. Acta. 4: 137-143.

CUNHA, J. da - 1943 - Cobre do Jaurne Lagoas Aleakinas do Pantanal (Mato Grosso). LPM/DNPM. (Bol. 6). Rio de Janeiro. $44 \mathrm{p}$.

DARBYSHIRE, D.P.F. - 1977 - Results of age determination programe. Santa Cruz. GEOBOL/IGS-ODA. Eastern Bolivia Mineral Exploration Project. Report $9.98 \mathrm{p}$.

DEER, W.A.; HOWIE, R.A. \& ZUSSMAN, J. - 1977 - An Introdiction to the Rock

Forming Minerals. London. Longman. $528 \mathrm{p}$.

FERREIRA FILHO, C.F. \& BIZZI, L.A. - 1985 - Caracterizaçao dos Cumulados Mdficos Granulitizados do Rio Alegre - MT. II Simp. Geol. do Centro-Oeste. Goiânia. GO.

FIGUEIREDO, A.J.; BARROS, A.M; EULÁLIO FILHO, A.; RODRIGUES, A.P.; BARRETO, B. de F; COUTO, J.G.P.; REICH, J.L.; COSTA, S.A. de G.; REZENDE FILHO, S.T. de; PASTORE JÚNIOR, W.P.; BERBERT, C.O; OLIVATTI, O.; ARAÚJO, A.G. de; TRIGUIS, J.A.; MELO, J.C.R. de; - 1974 - Projeto Alto Guaporé. Goiânia. DNPM/CPRM. Vol. 2 e 11 (Relatório 2323).

HASUI, Y. \& ALMEIDA, F.F.M. de;-1970-Geocronologia do Centro Opste Brasileiro. Bol. Soc. Bras. Geol. 19: 5-26.

HYNDMAN, D.W. - 1972- Petrology of Igneous and Metamorphic Racks. McGraw-Hill Book Co. New York. 533 p.

HUGHES, C.J. - 1973 - Spilites, keratophyres, and the igneous spectrum. Geol. Mag. $109(6) ; 513-527$.

IRVINE, T.N. \& BARAGAR, W.R.A. - 1971 - A guide to the chemical classification of the common volcanic rocks. Canadian Journal of Eartli Sciences, 8 : 523-548. 
JENSEN, L.S. - 1976 - A new cation plot for classifying subalkalic voladnic rocks. Ontario Department of Mines, Miscellaneous Paper. V. 66.

LEITE J.A.D. - 1989 - Contexto geologico e geoquimica das lavas máficas da Sequência Vulcano-Sedimentar Quatro Meninas, Municipio de Indiavai $M T$. Porto Alegre. URGS. Dissertação de Mestrado. 82 p. Inédito.

LITHERLAND, M.; ANNELS, R.N.; DARBYSHIRE, D.P.F.; FLETCHER, C.J.N.; HAWKINS, M.P.; KLINK, B.A; MITCHELL, W.I: O'CONNOR, E.A: PITFIELD, P.E.J.; POWER, G. \& WEBB, B.C. - 1989 - The Proterozic Eastern Bolvia and its relationship to the Andean Mobile Belt. Prec. Res. 43: 157 174.

LITHERLAND, M. \& BLOOMFIELD, K. - 1981 - The Proterozdic History of Eastern Bolvia. Prec. Res. 15: 157-179.

MacKENZIE, W.S.; DONALDSON, C.H. \& GUILFORD, C. - 1982- Allas of igneous rocks and their textures. Longman. London. $148 \mathrm{p}$.

MATOS, J.B. de; \& RUIZ, A.S. - 1990 - Contribuiço d Geologia da Follha Santa Rita-Mato Grosso. I Enc. Cient. Des. Tec. Amazonia e Centro-Oeste. Cuiabá. Atas. Brev. Comun. p. 43-44.

MATOS, J.B. de; \& RUIZ, A.S. - 1991 - Contribuţ̧a d geologia da Folla Santa Rita-Mfato Grosso. Anais... III Simp. Geol. Centro-Oeste. Cuiabá. SBG. 1: 122-130.

MEHNERT, K.R. - 1971-Migmatites and the origin of granitic rocks. Elsevier Publ. Co. Amsterdan. 405 p.

MENEZES, R.G.; SILVA, P.C.S.; SILVA, L.C. da; LOPES JÚNIOR, I; BEZERRA. J.R.L.; TAKAHASHI, A.T. \& FERREIRA, J.C.G. - 1991 - Geologia Argueano-Proterozícica da Folha Pontes e Lacerda - Estado de Mato Grosso-SD21-Y-C-II. Anais... III Simp. Geol. Centro-Oeste. Cuiabá. SBG. 1: 131-143.

MIYASHIRO, A. - 1973 - Metamorphism and Metamorphic Belts. George Allen \& Unwin. London. $492 \mathrm{p}$.

MONTEIRO, H.; MACEDO, P.M. de; SILVA, M.D. da; MORAES, A.A. de; MARCHETTO, C.ML. - 1986 - O Greenstone Belt do Alto Jaurú In: CONGR. BRAS. GEOL. 34. Goiânia. Anais... 2: 630-646.

MORAES, I.R. \& MAKHOUL, E.R.O. - 1986 - Contributiço da Geologia da Serra Salto do'Agtapel - Stib-drea I. Caceres MT. Trabalho de Graduação. UFMT. 86 p. (Inédito).

NEDER, R.D.; RESENDE, W.M. \& RONDON, S.L. - 1984 - Projeto Rochas Máfcas/Uliramáficas das Cabeceiras do Rio Guaporé. Relatórió Interno da Comp. Matogros. de Mineração - METAMAT. 26 p. (Inédito). 
OLIVATTI, O. - 1981 - Problentas Estratigraficos do Pré-Cambriano na regiao sudoeste da Estado de Mato Grosso - Tentativa de Correlaça com o oriante boliviano. In: Simp. Geol. Centro-Oeste. 1. Goiânia. SBG. 1: 196-212.

OLIVATTI, O. \& RIBEIRO FILHO, W. - 1976 - Revisdo da Geologia do CentroNorte de Mato Grosso. Projetos Centro-Oeste de Mato Grosso, Alto Guaporé e Serra Azul Goiânia. CPRMDNPM. 51 p. (Inédito).

PEARCE, J.A. - 1975 - Basali geochemistry used lo investigate past tectonic enviromment on Cyprus. Tectonophysics 25: 41-67.

PEARCE, J.A. - 1982 - A user's guide to basalt discrimination diagrams. Apostila. (Inédito).

PETTIJOHN, F.J. - 1975 - Seclimentary Rocks. Harper \& Row Publ. New York.

PINHO, M.A de S.B. - 1990 - Geologia, Peirologia e Geoculmica das Rochas Ocorrentes ao longo do Rio Aguapet-Sudoeste do Craton AmazonicoPontes e Lacerda - MT. Porto Alegre. URGS. Dissertação de Mestrado.199 p. (Inédito).

RAMSAY, J.G. - 1967 - Folding and Fraciuring of Rocks. MoGraw-Hill Book Co. New York. 568 p.

RIBEIRO FILHO, W. \& FIGUEIREDO, A.I. de A - 1974 - Reconhecimento Geológico da regiao oeste do Estado de Mato Grosso. In: CONGR. BRAS. GEOL. 28. Porto Alegre. Anais... p. 27-35.

RIBEIRO FILHO, W; LUZ, J. da S. \& ABREUFILHO, W. - 1975 - Projeto Serra Azul. Goiania DNPM/CPRM. V.1. 104 p. - Relatório Final (Inédito).

RUIZ, A.S. - 1992 - Contribuiçà à geologia do Distrito de Cachoeirinha $M T$. São Panlo. IG-USP. 98 p. Dissertação de Mestrado.

SAES, G.S.; LEITE, J.A.D. \& WESKA, R.K. - 1984 - Geologia da Folha Jaunt (SD-21-Y-C-III): Uma sintese dos Conhecimentos. In: CONGR. BRAS. GEOL. 33. Rio de Janeiro. 1984. Anais... SBG. V.5. p. 2193-2204.

SAES, G.S.; LEITE, J.A.D; ALVARENGA, C.J.S.; FERREIRA FILHO, C.F.\& MATOS, J.B. de; - 1986 - Projeto Jaurt-Reserva do Cabaçal MT. - Relatório Final - Convênio DNPM/UFMT. Cuabá MT. 23 p. (Inédito).

SHERVAIS, J.W. $-1982-T i-V$ plots and the petrogenesis of the modern and ophiolitic lavas. Earth and Planetary Science Letters, 59: 101-118.

SILVA, C.G.; LIMA, M.I.C. de; ANDRADE; A.R.F. de; ISSLER, R.S.; GUIMARÃES,G.; LEAL, J.F.V;; BASEI, M.A.S.; DALL'AGNOL, R.; TEIXEIRA, J. B.G; MONT.ALVÃO, R.M.G. de; - 1974 - Geologia. In: BRASIL. MME-SG. Projeto RADAMBRASIL. Folha SB-22 Araguaia e parte da Follha SC-22 Tocantins. Rio de Janeiro. p. 3-143. (Levantanento de Recursos Naturais, 4). SOUSA, F.J.de; - 1991 - Revisio da Geologia da porsto SW do Estado de Mato 
Grosso, S do Estado de Rondônia e do Leste da Bolivia. Rev. Bras. Geoc. 21 (1): 74-81.

SOUZA, E.P. \& HILDRED, P.R. - 1980 - Contribuç̧o ao Estudo da Geologia do Grupo Aguapet Mato Grosso. In: CONGR. BRAS. GEOL. 31. Camborin. V. 2. p. 587-598.

SPRY, A. - 1974 - Metamorphic Textures. Pergamon. Oxford. 350 p.

STRECKEISEN, A. - 1976 -To each plutonic rocks its proper name. Earth Sci. Rev. 12: 1-33.

TAYLOR, S.R \& MCLENNAN, S.M. - 1985 - The continental crust: Its Composition and Evolution. Blackwell. Oxford. 312 p.

TASSINARI, C.C.G. - 1981 - Evoluço Geotectonica da Provincia Rio NegroJuruena na Regido Amazônica. São Panlo. IG-USP. Dissertação de Mestrado 99 p. 2.V. (Inédito).

TRÖGER, W.E. - 1979 - Optical Determination of Rock-Forming Minerals. Part 1. (Determinative Tables). English Edition of the Fouth German Ed. Stuttgart. E. Schweizerbart'sche. $191 \mathrm{p}$.

TURNER, F.J. - 1978 - Metamorphic Petrology. McGraw-Hill Book Co. New York. TURNER, F.J. \& VERHOOGEN, J. - 1960 - Igneous and Metamorphic petrology. MoGraw-Hill Book Co. New York.

VASCONCELOS, L.A. - 1982 - Prospeçao Geoquinica Regional no Craton do Guapore, a SSE de Pontes e Lacerda MT. In: CONGR. BRAS. GEOL. 32. Salvador. V. 5. p. 1841-1853.

VIEIRA, A.J. - 1965 - Geologia do Centro-Oeste de Mato Grosso. Ponta Grossa. PETROBRÁSIDEBSP. 81 p. (Boletim 303).

WILLIAMS, H.; TURNER, F.J. \& GILBERT, C.M. - 1954 - Petrography. An Introduction to the Study of Rocks in Thin Sections. W.L. Freeman. San Francisco. $434 \mathrm{p}$.

WINCHESTER, J.A. \& FLOYD, P.A - 1977 - Geochemical discrimination of different magmiaseries and their differentiation products using immobile elements. Chemical Geology. V. 20. p. 325-343.

WINKLER, H.G.F. - 1977 - Petrogênese das Rochas Metamórjicas. (Trad. C. Burguer Jr.). Porto Alegre. Edgard Blücher/URGS. 254 p. 
ANExO 01 - Matodo Analitico e Limites de Detecra para as Análises Efetuadas no laboratorio de Geoquímica do Instituto de Geociencias de Hamburgo, R.F. da Alemanha, atraves de Fluorescentia de ratos-x.

Elementos Maiores Limites de Detecra $0 \%$

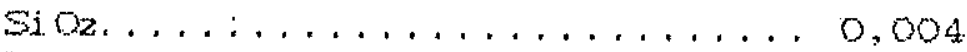

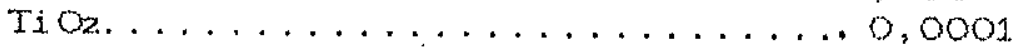

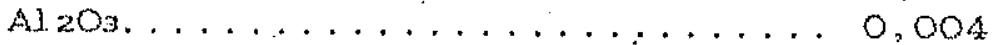

$\mathrm{Fe}, \ldots \ldots \ldots \ldots \ldots, \ldots \ldots \ldots, \ldots \ldots \ldots$

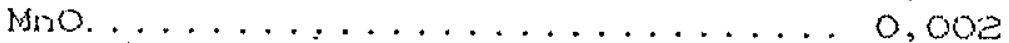

$\operatorname{MgO} \ldots \ldots \ldots \ldots \ldots \ldots \ldots, \ldots \ldots \ldots$

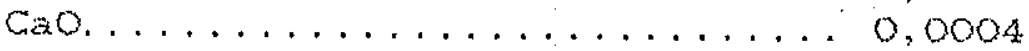

$\mathrm{NazO} \ldots \ldots \ldots \ldots, \ldots \ldots, \ldots \ldots$

$\mathrm{k} 20 \ldots \ldots \ldots \ldots \ldots, \ldots \ldots \ldots, \ldots \ldots \ldots$

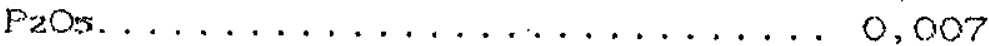

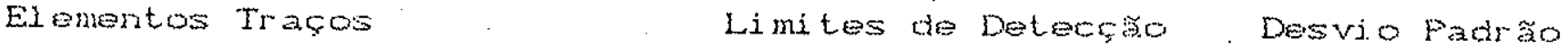

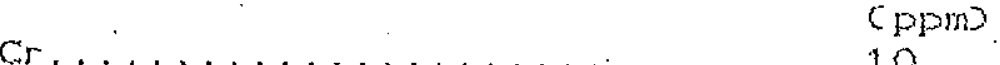

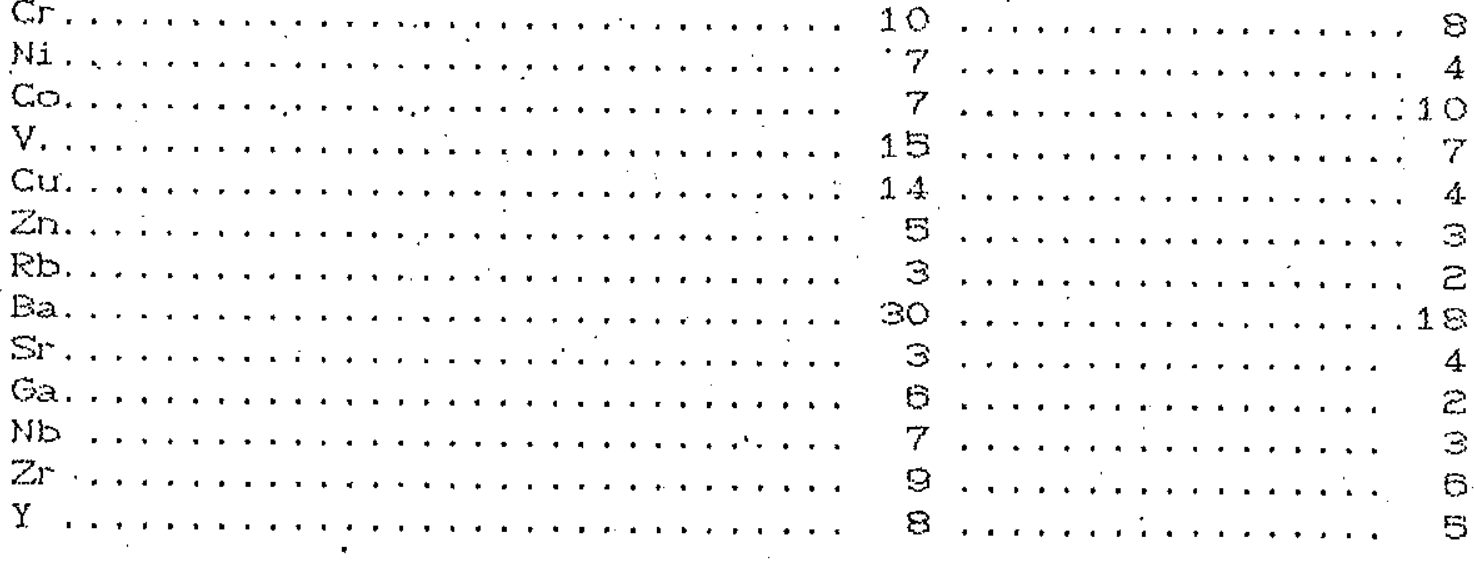

Os dados referentes aos elementosielementos tracos, S, Fb, Th, U, Lia, Ne No dizem Nespejto a analises. semi-quantitativas c absol uto. 
ANEXO 02 


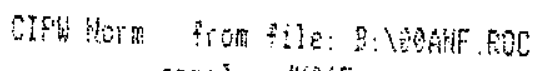

samp: Hos

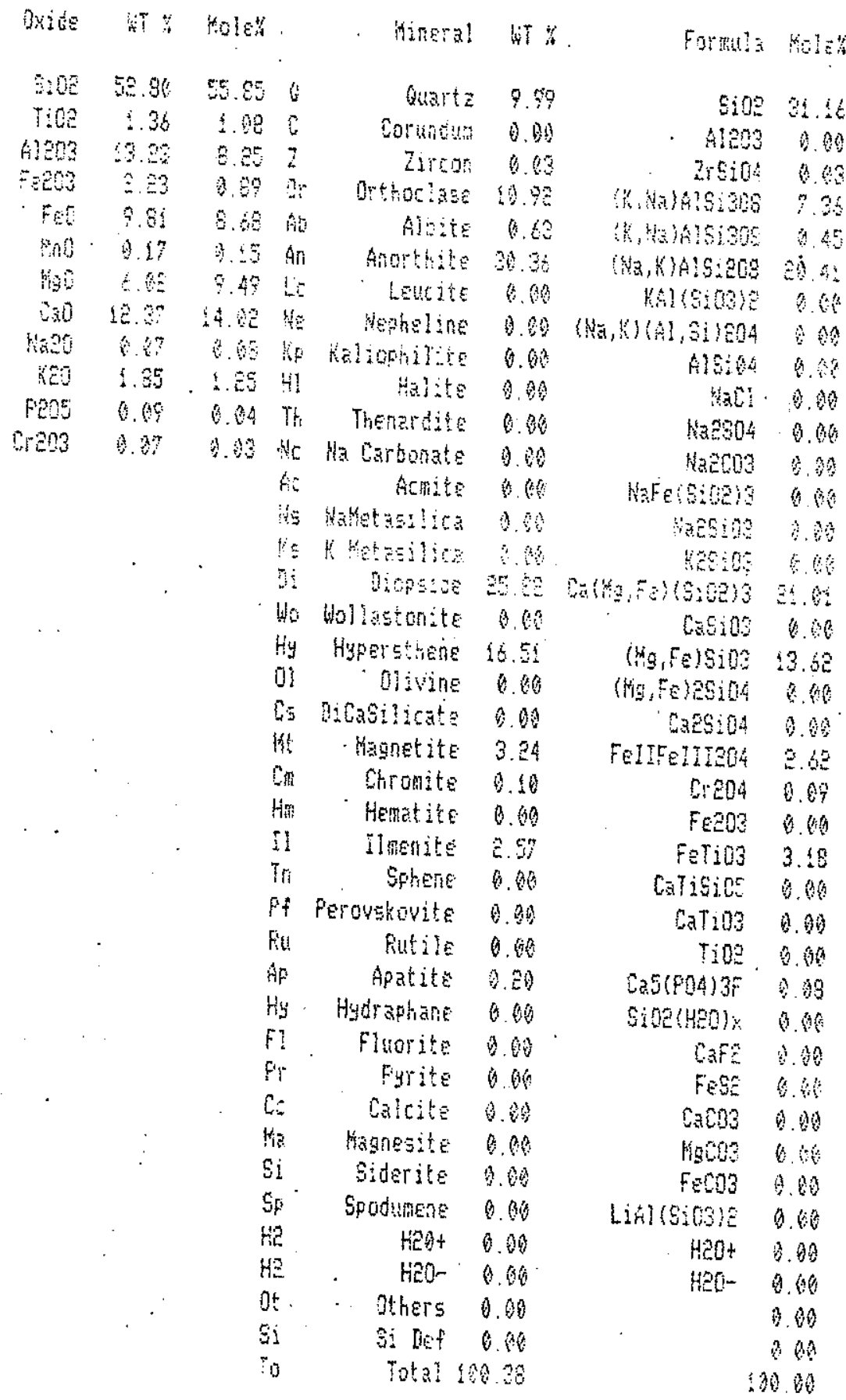

Sresi

Frojection lats

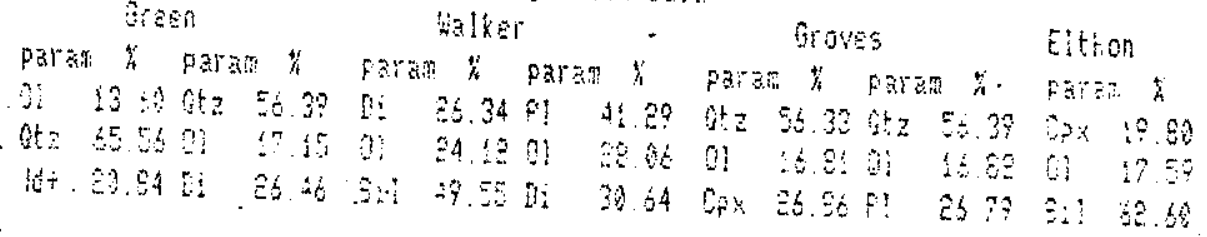




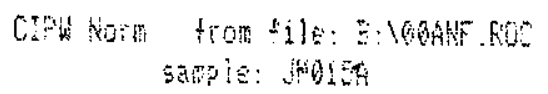

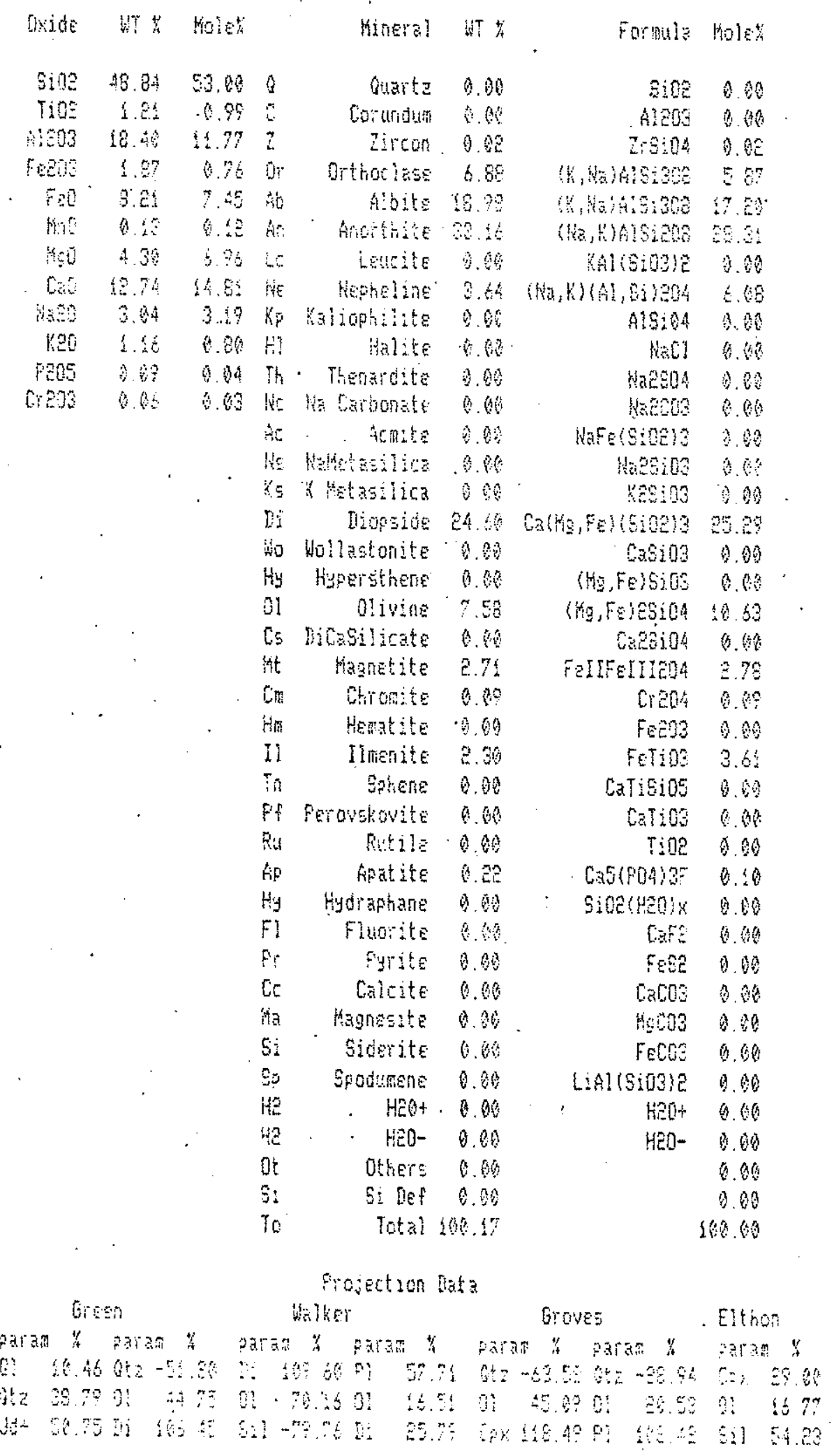




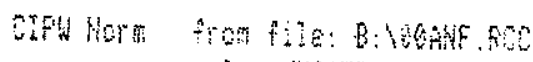

saite: Jorot

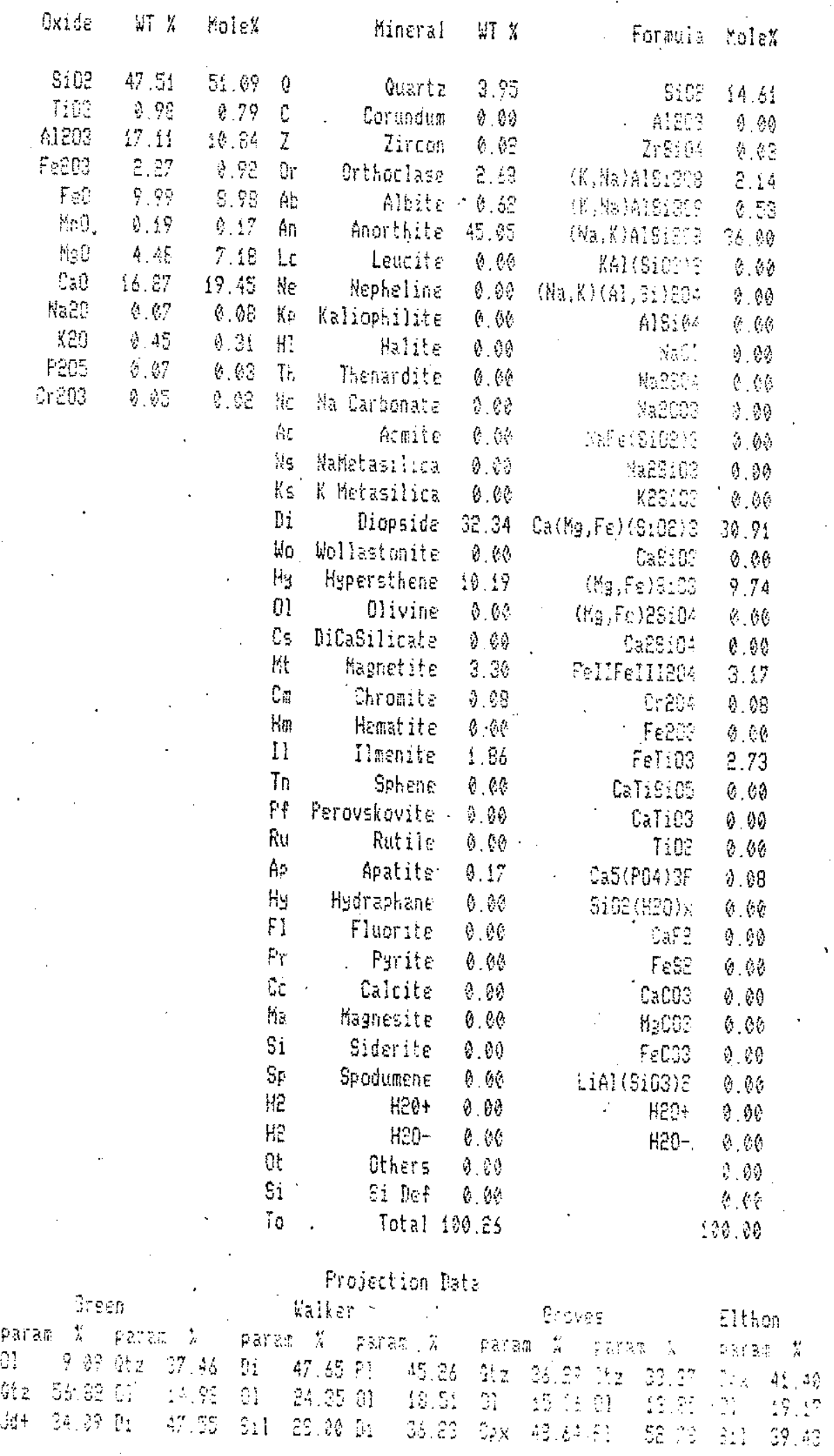




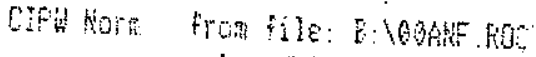

sample: Jhas

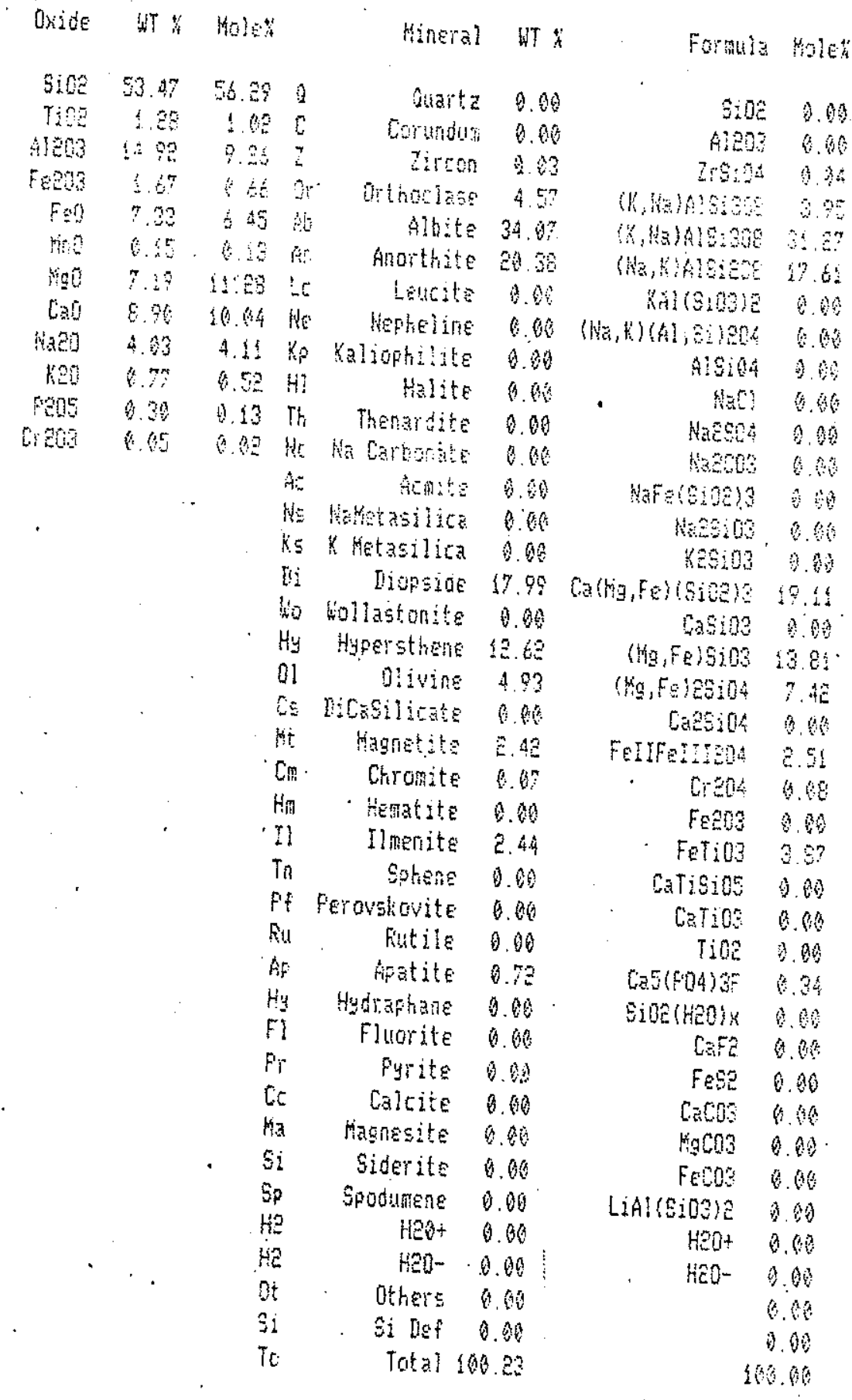

\footnotetext{
Creen Projettion lata

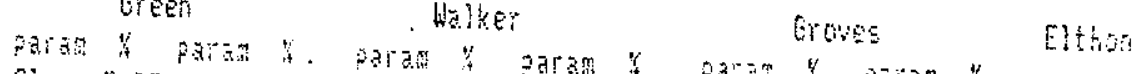

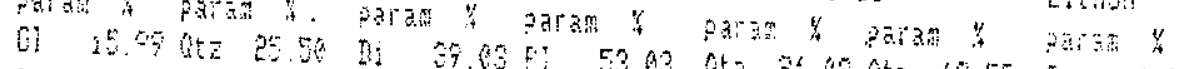

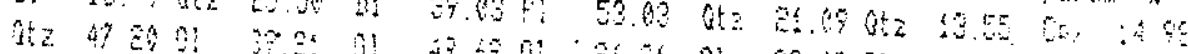

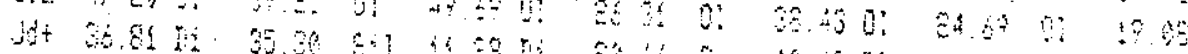




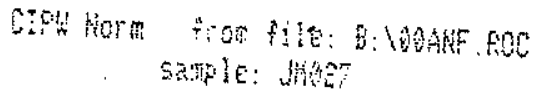

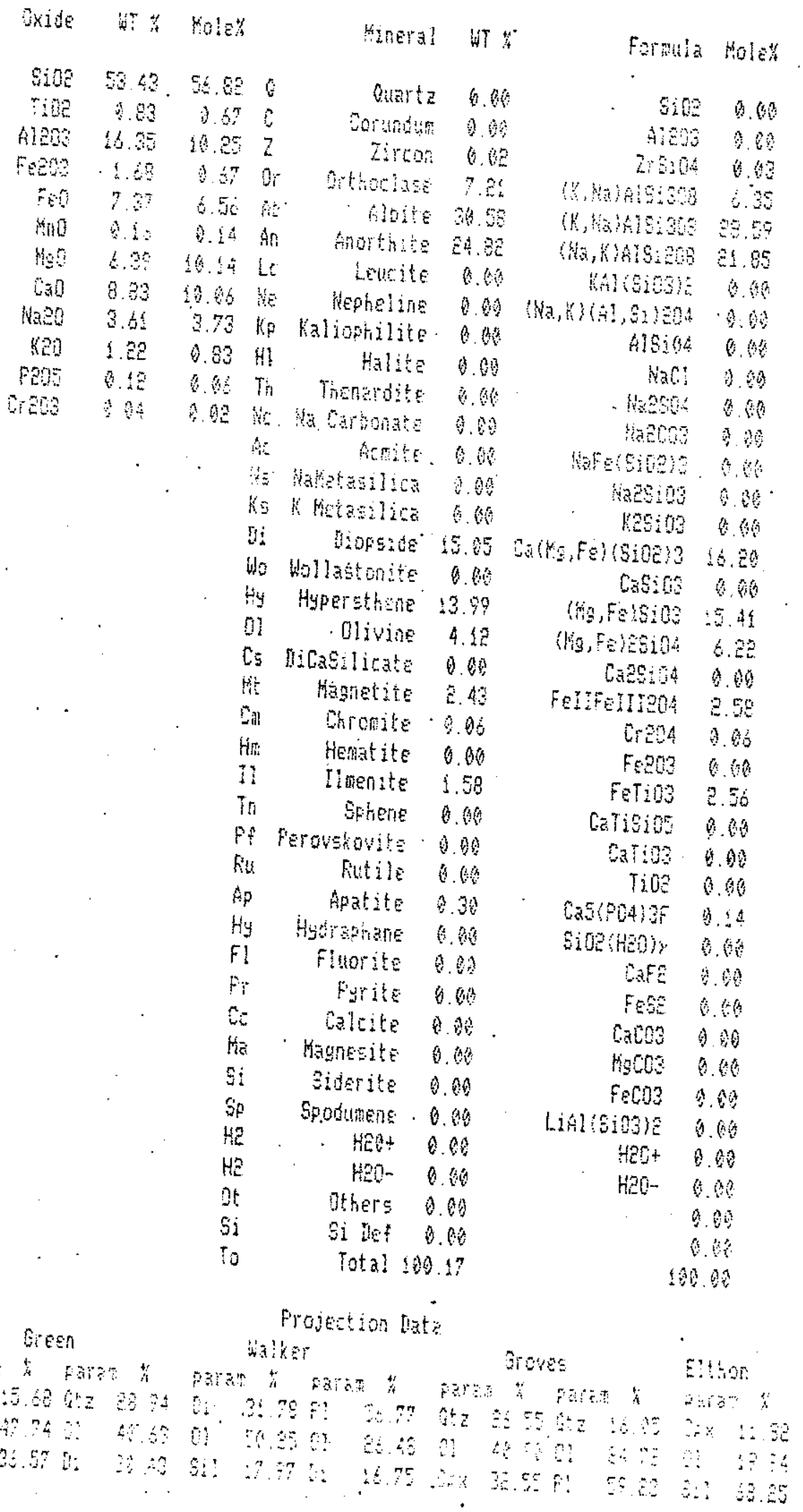




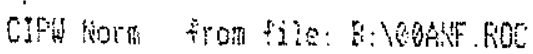 \\ aㅗำ: Hose}

\begin{tabular}{|c|c|c|c|c|c|c|c|c|}
\hline Oxi & & W' & hole & & Mimeral & WT & Forminia & Holes \\
\hline Sif & & 53.23 & 57.7 & la & Quartz & 4.59 & side & $\$ 6.72$ \\
\hline $\mathrm{Tit}$ & & 1.5 & 1.2 & $C$ & Corthdus & 0.00 & A1213 & 0.40 \\
\hline Alet & & 16.23 & 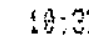 & 2 & Ziroon & 0.00 & 215104 & 0.96 \\
\hline$F E C$ & & 2.20 & 6.7 & or & Orthociase & 2.68 & $(k, 1))$ AISison & 2.: \\
\hline & 00 & 9.64 & 8.7 & 能 & Albite & 27.81 & $(6,14), 43,308$ & 23..2: \\
\hline & 10 & b. & Q. $\bar{E}$ & A & Ariorthite & $2 e .2 A$ & Hz,kisien & D. 19 \\
\hline 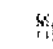 & 0 & 4.07 & 3.5 & 3 & Leucite & 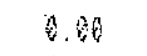 & Haloiose & 0.60 \\
\hline C & & 8.96 & 30.4 & We & Nefhelime & 0.981 & 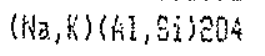 & 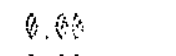 \\
\hline Ha: & & 3. ह? & 3.4 & $5 p$ & Kalophitite & 0.0 & Alsit & 0.00 \\
\hline & 0 & 0.45 & 6.3 & it & Hoilte & 8.06 & $\mathrm{WaCl}$ & 0.6 \\
\hline $\mathrm{Pz}$ & & 0.19 & 0.0 & ? Th & Thenardite & 000 & $\$ x \leq 04$ & 0.00 \\
\hline$m o$ & & 6 & 0.0 & $B \mathrm{kt}$ & IA Cirtonate & 0.00 & Naecos & 6.60 \\
\hline & & & & Ac & Acmite & 0.00 & Wafe(s.02) & 0 \\
\hline & & & & 结 & Whetasilica & 0.0 & Wat 2500 & 6.9 \\
\hline & & & & $k 5$ & R. Hetasiliea & 8.92 & $109: 03$ & 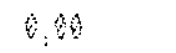 \\
\hline & & & . & Ii & Inofsude & 12.550 & Ca(ho, fe) (Bige) & $11.8:$ \\
\hline & & & & to & Wollastonite & 0.00 & Casido & 860 \\
\hline & & & & Hy & Hypersthene & 17.67 & $(\mathrm{Hg}, \mathrm{Fe}) \mathrm{si03}$ & 16.81 \\
\hline & & & & at & Olivine & 9.90 & $\left(n_{B}, F \in\right) 2 S i 04$ & 0.60 \\
\hline & & . & & $C_{5}$ & Ilirosilicate & 0.00 & $6225 i 04$ & a. wh \\
\hline & & & & st & Wagretite & 3.18 & FEIIFEIIIEQ4 & 3.05 \\
\hline & & & & Com & Chronite & 0.00 & $\operatorname{cran}$ & 0.00 \\
\hline & & & & Him & Heratite & 000 & $\mathrm{FeCO3}$ & 0.0 \\
\hline & & & - & I! & Ilmenite & 2.97 & FETIOS & 5.4 \\
\hline & & & & in & Sphene & 0.00 & Catisios & 0.80 \\
\hline & & & & $F f$ & Ferouskovite & 0.00 & Catiog & 0.60 \\
\hline & & & & Eu & Rutile & 0.00 & Tioe & 0.0 \\
\hline & & & & Ap & Ratite & 0.45 & CaEtFOA) & 680 \\
\hline & & & & Hiy & Hydraphatie & 0.00 & sine(heo)x & 0.0 \\
\hline & & & & $\mathrm{Fi}$ & Fluorite & 0.68 & $\mathrm{CaF}$ & $\theta .60$ \\
\hline & & & & pr & Pyrits & 0.00 & FESE & 0.60 \\
\hline & & & & dt & Calcite & 0.80 & $\operatorname{cocos}$ & a. \\
\hline & & & & 紋 & Wagnesite & 8.80 & 49003 & 0.00 \\
\hline & & & & si & Siderite & 0.60 & FECU: & 0.60 \\
\hline & & & & 5 & Sodและก & 0.00 & LIAIYS:03)E & 0.80 \\
\hline & & & & $\mathrm{HE}$ & $\mathrm{KeOH}$ & 0.08 & HEIt & Q a \\
\hline & & & & $H 2$ & WEO- & 0.60 & $420-$ & 0.09 \\
\hline & & & & $0 t$ & Others & 0.00 & & Q. \\
\hline & & & & $\$ !$ & Si nef & 0.00 & & 8.0 \\
\hline & & & & To & Total & 100.81 & & 60.60 \\
\hline \multicolumn{9}{|c|}{ Projection lata } \\
\hline \multicolumn{4}{|c|}{ Greer: } & \multicolumn{2}{|r|}{ Helker } & . & Groves & Elthon. \\
\hline aram & 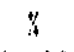 & parza & 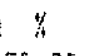 & fartat & 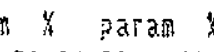 & tata & n ${ }^{\prime}$ paran " & parag 4 \\
\hline$\pi$ & 11.86 & $0+25$ & 58 & nis & 240695 & $23 \quad 0 t z$ & so 50 atz 33.6 & Sfl ? \\
\hline itz & 55.74 & 1013 & 26.90 & 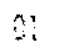 & $77.2601 \quad 27$ & $.350 !$ & E. $9401 \cdot 16.65$ & $0 ?: 7$ \\
\hline$j+$ & 32.86 & Ii & 29.83 & $\mathrm{Sil}$ & 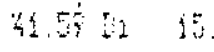 & $42 \mathrm{Cpx}$ & 020014978 & $8 \div 3$ \\
\hline
\end{tabular}


EPf Horm tron tile: B: vatuf noc.

gente: Jisto

\begin{tabular}{|c|c|c|c|c|c|c|c|}
\hline Dride & स\% & Bol $\varepsilon_{\%}^{\prime \prime}$ & & Hineral & WT \% & Formtla & Holet \\
\hline $\operatorname{sine}$ & 54.45 & 54.65 & Q & Quertz & 8.25 & sion & 26.8 \\
\hline Tige & 1.69 & ). 36 & 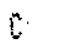 & Corundua & 0.90 & AiE? & 0.60 \\
\hline Alges & 53.83 & 8.66 & 2 & Zircon & 0.06 & 215104 & 0.60 \\
\hline Fogns & 2.80 & 1.14 & Dr & Orthoclase & 2.15 & (K, Na) $19: 308$ & ?. 48 \\
\hline Fon & 10.57 & $\{1.17$ & fit: & Altite & 7.45 & 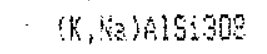 & 5.57 \\
\hline tho & s. 27 & A. 65 & Aī & Anorthite & 32.74 & 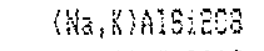 & c. 3.9 \\
\hline $\sin$ & 7.22 & 11.26 & LE & Leucite & 6. 6 & Wi1 1503$)$ & 9.4 \\
\hline 640 & 7.57 & 9.89 & He & Nepheline & 0.04 & 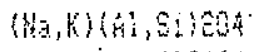 & $8.0 \%$ \\
\hline 隹的 20 & 6.80 & 0.91 & $K_{F}$ & Kolioptilite & 0.60 & Alsió & 0.68 \\
\hline$x \in 0$ & 0.36 & 0.24 & $\mathrm{HH}$ & : Halite & 0.98 & $\mathrm{HaCl}$ & 8.90 \\
\hline Fegs & 6.99 & 0.04 & Th & Thenardite & 6.06 & 42004 & 6.08 \\
\hline \multirow[t]{4}{*}{$\operatorname{cr} 203$} & 9.89 & 8.80 & Ni & Sa Carbonate & 0.00 & 142003 & 0.00 \\
\hline & & & AC & kuthe & Q. 40 & Matoioges & 9.60 \\
\hline & & & is & datetasilics & 0.60 & 432503 & $480^{\circ}$ \\
\hline & . & & $k 5$ & h Hetazilica & 2.30 & nosios & 4.8 \\
\hline \multirow[t]{6}{*}{. } & & & $0 \mathrm{i}$ & Diofside & 12.71 & 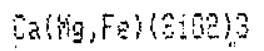 & 9.95 \\
\hline & & & Wo & Wollestonite & 60 & Cesios & 0.0 \\
\hline & & $\cdot$ & Hy & Hypersthene & $31.4 B$ & $($ tha, Fo) 803 & 26.93 \\
\hline & & . & 01 & Olivine & 0.00 & (KG,FEIDSOG & 6.60 \\
\hline & & & $\mathrm{cs}$ & DiCasilicate & 6.00 & Cacsiod & 0.80 \\
\hline & & & 筈 & Magnetite & 4.15 & FEIIFELIIDOA & 3.2 \\
\hline & & . & Cin & Chromite & 4.90 & Cront & 0.90 \\
\hline & & . & 翰 & Hematite & 6.6 & Fets & 0.60 \\
\hline & & & II & IIenate & 1.89 & Fotins & 2.44 \\
\hline & . & . & Tri & Sphene & 0.06 & caTisios & 0.60 \\
\hline & & & $P f$ & ferovstoutis & 0.0 & CATIOS & 0.80 \\
\hline \multirow[t]{12}{*}{$\cdot$} & & & Ru & Futile & 6.60 & TiQ & 0.60 \\
\hline & & . & sip & Apatite & 0.22 & Cas (FOA)3F & Q. 0 \\
\hline & & & Hy & Hydratiane & 6.60 & siterthos & 0.60 \\
\hline & & & 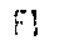 & Fluorite & 0.60 & Cafe & 0.00 \\
\hline & . & & $\mathrm{Fr}$ & Pyrite & 6.60 & Few & 0.10 \\
\hline & & & $C$ & Calcite & Q. & 6003 & 0.00 \\
\hline & & & His & Hagnesjte: & $\cdot 0.80$ & Hgats & 0.08 \\
\hline & & & $5 i$ & siderite & 0.60 & $\mathrm{FecO} 3$ & 0.60 \\
\hline & & & $S p$ & Spodumene & 0.06 & LifflYGiOSYE & 0.40 \\
\hline & & & $\mathrm{He}$ & $\mathrm{HeOt}$ & 0.90 & $\mathrm{HeOt}$ & 0.00 \\
\hline & & & $H^{2}$ & Hen- & 0.60 & $420-$ & 0.10 \\
\hline & & & $0 t$ & Others & 9.00 & & 0.80 \\
\hline & - & & 5 & Si IEf & 6.60 & & 6.9 \\
\hline & & & 10 & Tota! & 1806 & & 100.6 \\
\hline
\end{tabular}

Frojection lat?

\begin{tabular}{|c|c|c|c|c|c|c|c|c|c|c|c|c|c|}
\hline \multicolumn{4}{|c|}{ Bresi } & \multicolumn{4}{|c|}{ Halker } & \multicolumn{4}{|c|}{ toves } & \multicolumn{2}{|c|}{ Elthon } \\
\hline & 茫 & Faran & 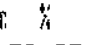 & para? & $x$ & parat & $\%$ & 785 & $n$ & parsm & $m i$ & 5t? & 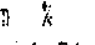 \\
\hline & 19 & 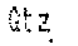 & 50.37 & 51 & \pm 1.5 & F! & 48.9 & ntz & 58.90 & $a t z$ & 49.3 & $i x$ & 6.8 \\
\hline & $5 \%$ & 01 & 28.66 & $\Omega$ & 36.76 & 01 & 45 & 01 & 3.14 & 5 & 25 & & 99.94 \\
\hline & 69.7 & $\mathrm{it}$ & 60.97 & $5: ?$ & 51.54 & $1:$ & 14.29 & G:V & 3.65 & $P !$ & 6.7\% & $31 !$ & 6.55 \\
\hline
\end{tabular}




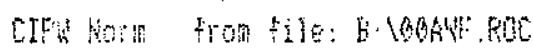

satple: which

\begin{tabular}{|c|c|c|c|c|c|c|c|c|c|}
\hline Oxiofe & & $H$ & Mol6ts & & minetal & HT & 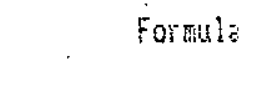 & 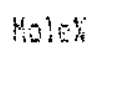 & \\
\hline $5 i n e$ & & 8.6 & 75.18 & $\theta$ & Wuetz 21 & 91.99 & $8 i 92$ & 50.11 & \\
\hline Tint & & 0.3 & 6.30 & r. & Cormonth & 0.60 & alsat & $3.6 \%$ & \\
\hline A:60 & & 5.47 & 9.84 & 2 & Zircon & 0.93 & 75104 & 0.90 & \\
\hline FEDS & & 0.5 & (4.2. & Gr & Dithorias it & 44.31 & (K, Na)isasos & 7.64 & \\
\hline$F 8$ & & B. & 2. 84 & $4 b$ & $A t a t g$ de & 42.72 & $(x, 12) 49: 300$ & 24.5 & \\
\hline Hit & & 0.65 & 6.65 & kn & Anothite is & 45.5 & (MS, BALSOS & 65 & \\
\hline $\mathrm{H}, \mathrm{g}$ & & 1.28 & 2.05 & Le & Leucite & 0.98 & KA! (QDS)E & 9.9 & \\
\hline $\mathrm{Cs}$ & & 2.95 & 3.30 & $\mathrm{de}$ & Mepreline & 0.640 & 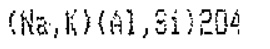 & 6.6 & \\
\hline$\left\{\begin{array}{l}2 B \\
2\end{array}\right.$ & & 5.195 & 5.20 & $k_{p}$ & Kalioptistes & 0.03 & 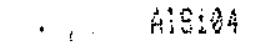 & 2.90 & i \\
\hline 12 & & 2.38 & 1.64 & $H:$ & Halite & 0.62 & Hoct & 6.90 & 1 \\
\hline 820 & & 0.13 & 6.65 & Itis & Thenardite & 0.00 & Mecos4 & 3.89 & \\
\hline 6003 & & 6.01 & Q & $\mathrm{Hi}$ & is Cribonate & 0.6 & wara & 0.0 & \\
\hline & & & & $a$ & homite & 0.0 & HaFerases & .3 & \\
\hline & & & & Ne & Mathesentire & a. & Hastes & (v) & \\
\hline & & 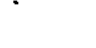 & . & $x=$ & " Hetsolick & 0.01 & "260.03 & $\because$. & \\
\hline & & & & $1:$ & Digride & 1.30 & 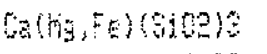 & 0.84 & \\
\hline & & & & W0 & Hollastonits. & 9.06 & $\sin 03$ & 2.00 & \\
\hline & & & & Hiy & Hyperstitene & 5.76 & (thg,Felsids & 3.8 & \\
\hline & & & & $0 !$ & Olivine & 0.06 & (Hag Fe) & 0.9 & \\
\hline & & & & $C_{5}$ & DiCasilinate & 络 00 & C238104 & 0.00 & \\
\hline & . & & & Mt & Mangtite & 9.75 & FEIIFEIIIEOA & 4.43 & \\
\hline & & & & Con & dhingine & b.6. & $\cdot \cot 204$ & 0.81 & \\
\hline & & & ${ }^{\circ}$ & $\mathrm{Hin}$ & Hematits & 9.90 & Fens & 1.90 & \\
\hline & & & & Il & Inenite & 0.70 & Fetio & 6.69 & \\
\hline & ${ }^{\circ}$ & & $\cdot$ & in & Srhene & 8.30 & GTSES5 & 8.00 & \\
\hline & . & & & $F$ & Fenovslovite & 0.60 & Gatina & 6.8 & \\
\hline & & & & Fis & Rutile & 0.90 & rine & 0.13 & \\
\hline & & & . & Ap & pextite & ใ. 25 & (AEFO4)3F & 0.97 & \\
\hline & & & & tiy & Hydraphane & 0.00 & Sigeingok & t. 64 & \\
\hline & & & & $\mathrm{Fl}$ & Fluorite & $0.6 \%$ & $\mathrm{C} F$ & 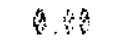 & \\
\hline & & & & Fr & Pyite & 0.80 & Fege & 0.8 & \\
\hline & & & & Co & Calcite & 6.06 & Cacts & 6.00 & \\
\hline & & & & $\mathrm{Aa}$ & Kagnasits & 9.00 & 4000 & 89 & \\
\hline & & & & $\$ i$ & Siderite & $B .96$ & Fean. & 0.4 & \\
\hline & & • & & $\$ ?$ & Groduinene & 0.00 & LiAl CODOSO & 8.80 & \\
\hline & & & & $\mathrm{HR}$ & Hen: & 0.00 & $\mathrm{HaOH}$ & 0 & . \\
\hline & & & . & 42 & HEO- & 0.06 & Hen- & 2.80 & \\
\hline • & . & & & $0 t$ & others & 6. 40 & & 0.6 & \\
\hline & & & & $\Delta$ & Si IE: & $0.00^{\circ}$ & & 30 & \\
\hline & & & & 70 & Total 200 & 100.19 & & $100<4$ & \\
\hline \multicolumn{10}{|c|}{ Projection yata } \\
\hline \multicolumn{3}{|c|}{ Greer } & & \multicolumn{2}{|r|}{ Holker } & \multicolumn{2}{|r|}{ Groves } & \multicolumn{2}{|l|}{ Eitron } \\
\hline paran & 7 & param & +4 & parst & ? p pran 4 & param & 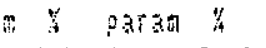 & 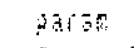 & $y$ \\
\hline $0 ?$ & 3.62 & $0 t=$ & 96 & $1:$ & 1.6E 87 b & ittz & 9e. 4 to 62 & $\%$ & $4.4 \%$ \\
\hline ate 7 & 183 & 01 & 398 & $0 !$ & $7550 ! \quad 426 ?$ & $0:$ & 5609 & 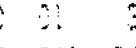 & 43 \\
\hline 19 & 240 & 19 & 23 & $5:$ & 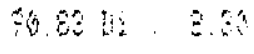 & $6 \%$ & $1.62: 3$ & 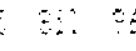 & 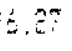 \\
\hline
\end{tabular}




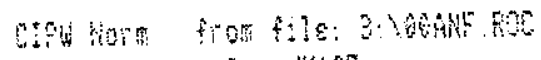

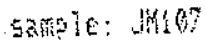

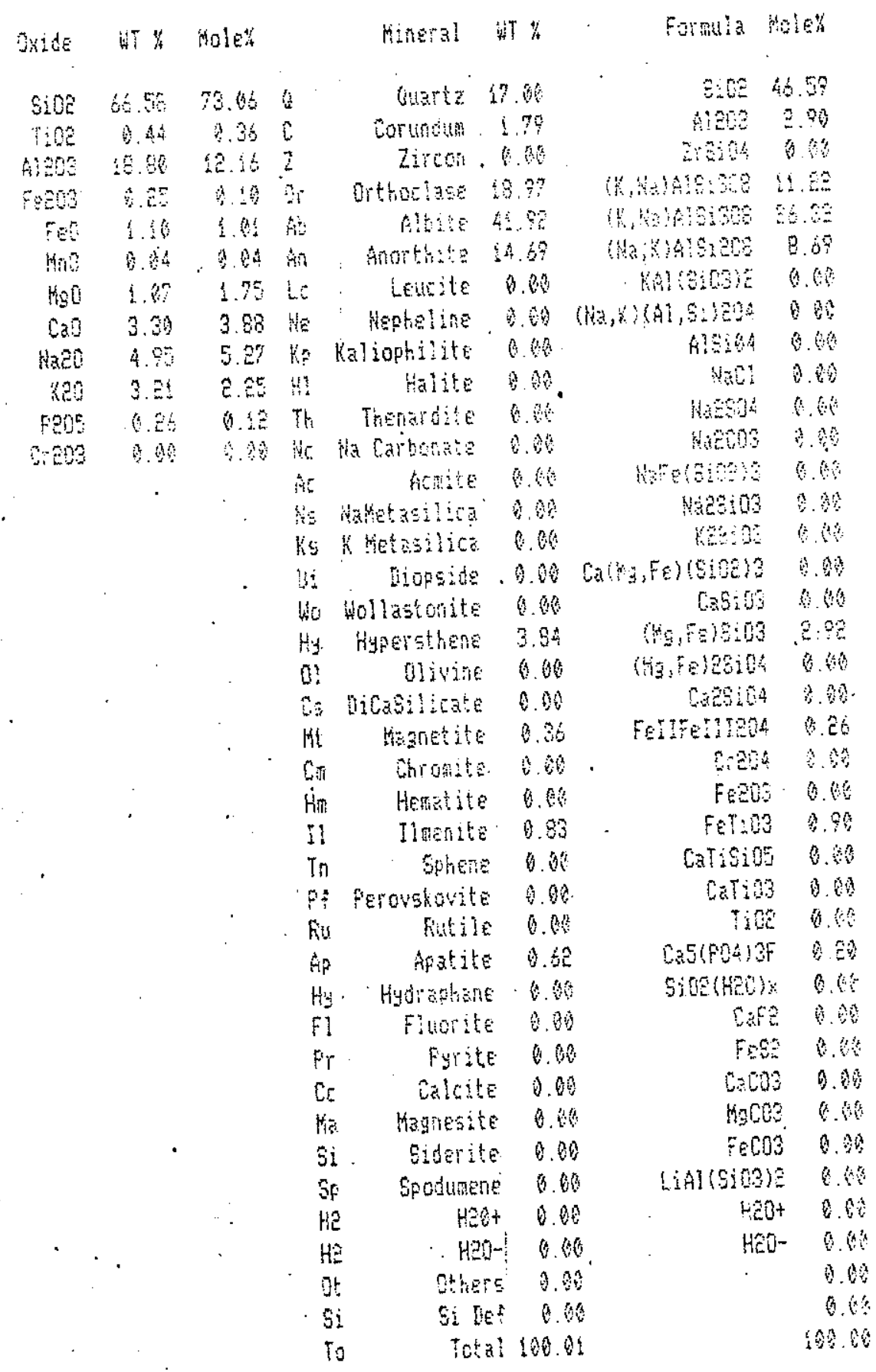

Frojection ista

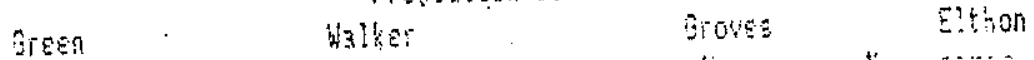

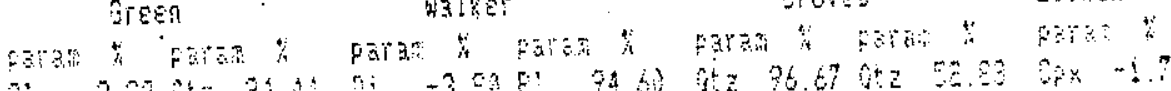

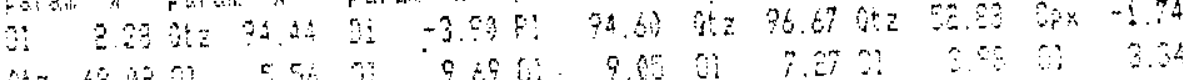

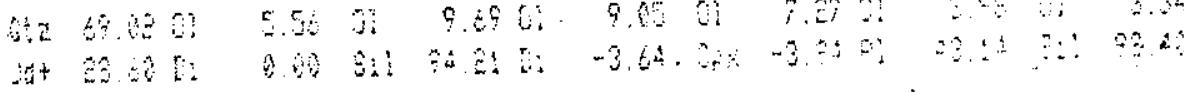


ANEXO 03 


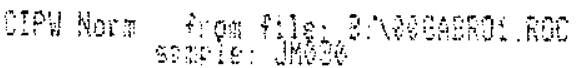

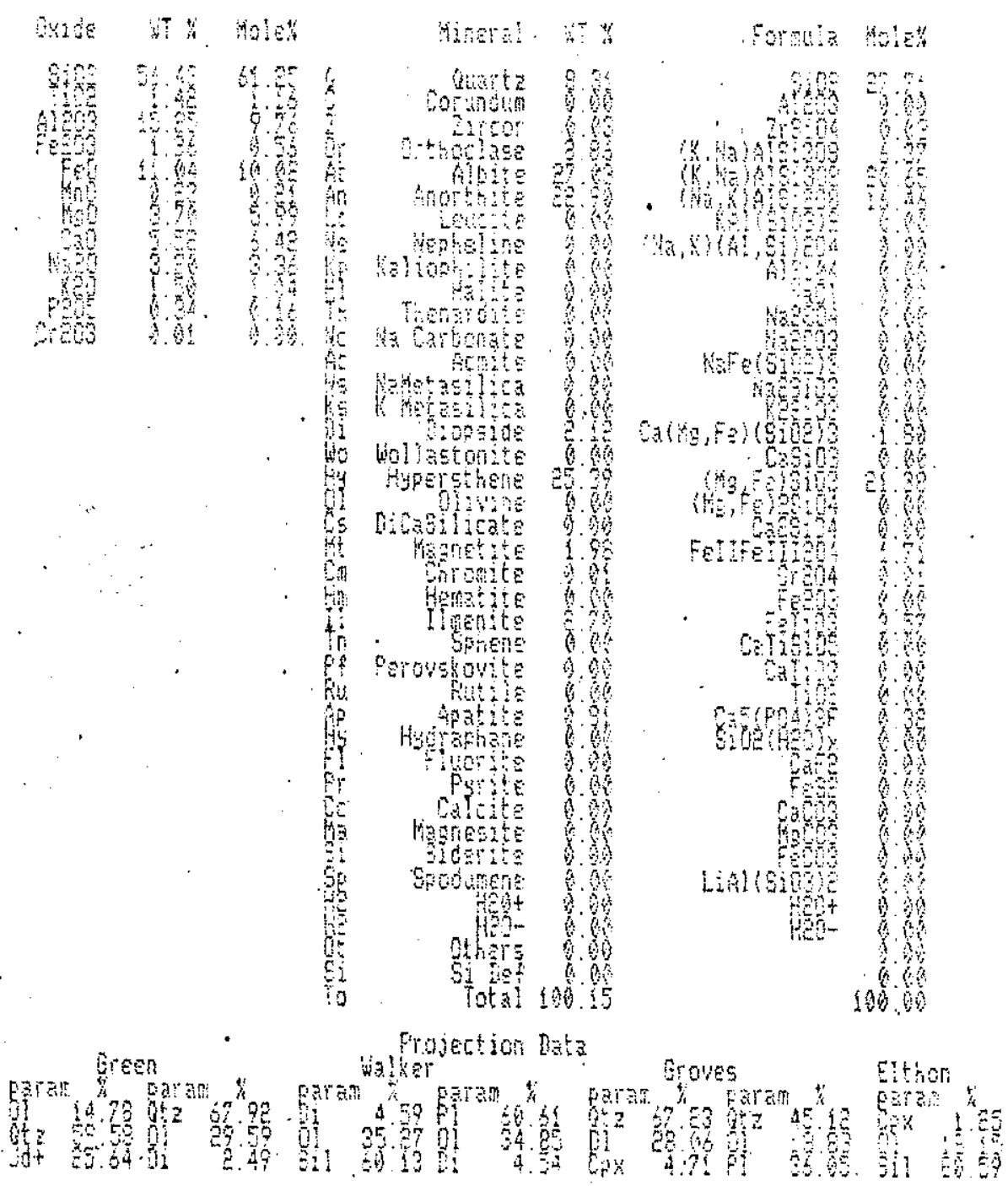




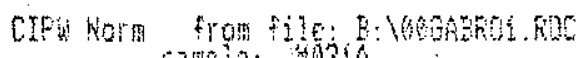

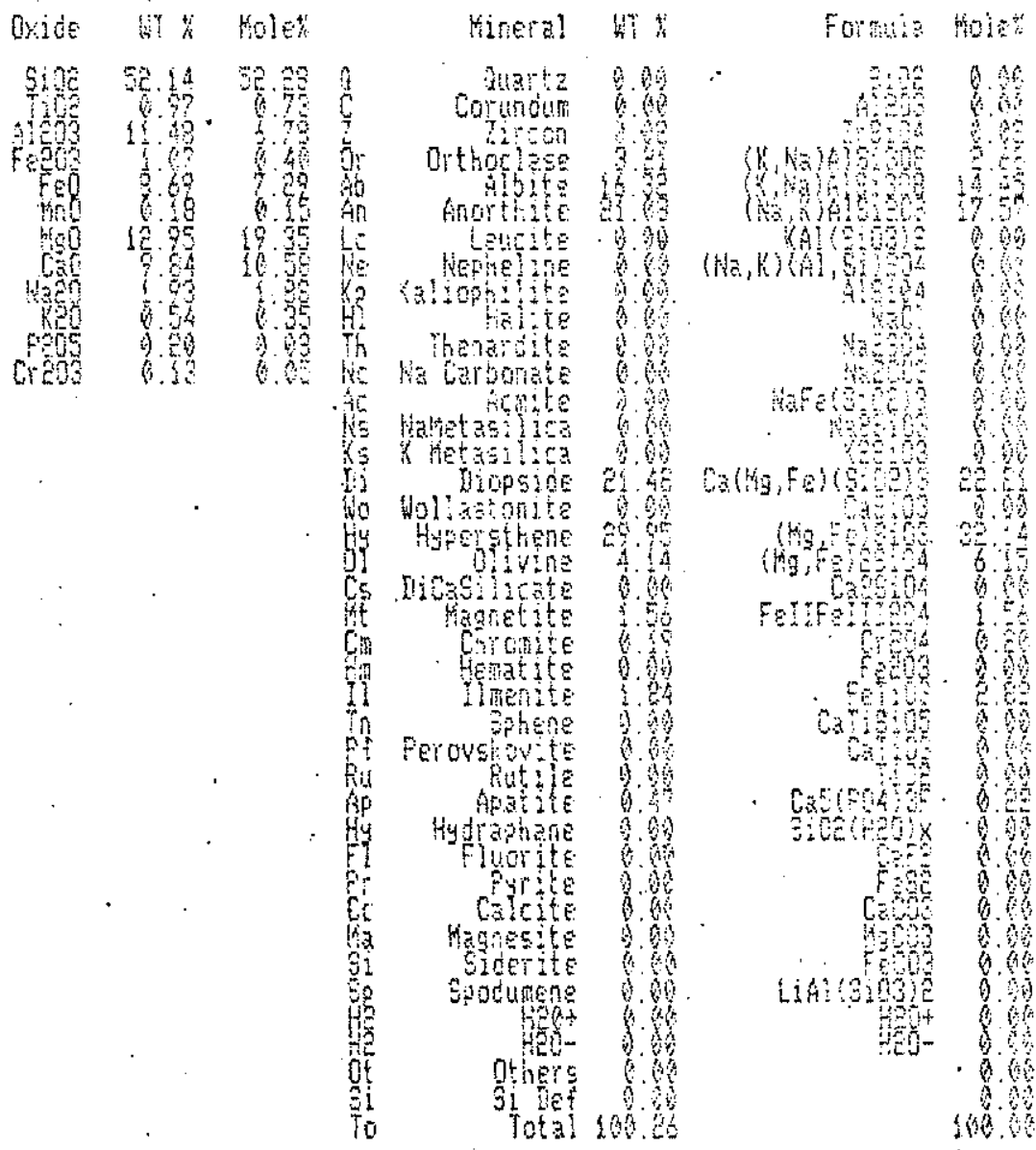

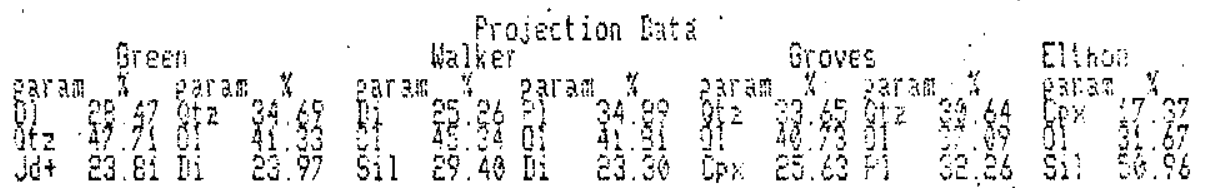




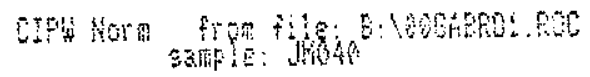

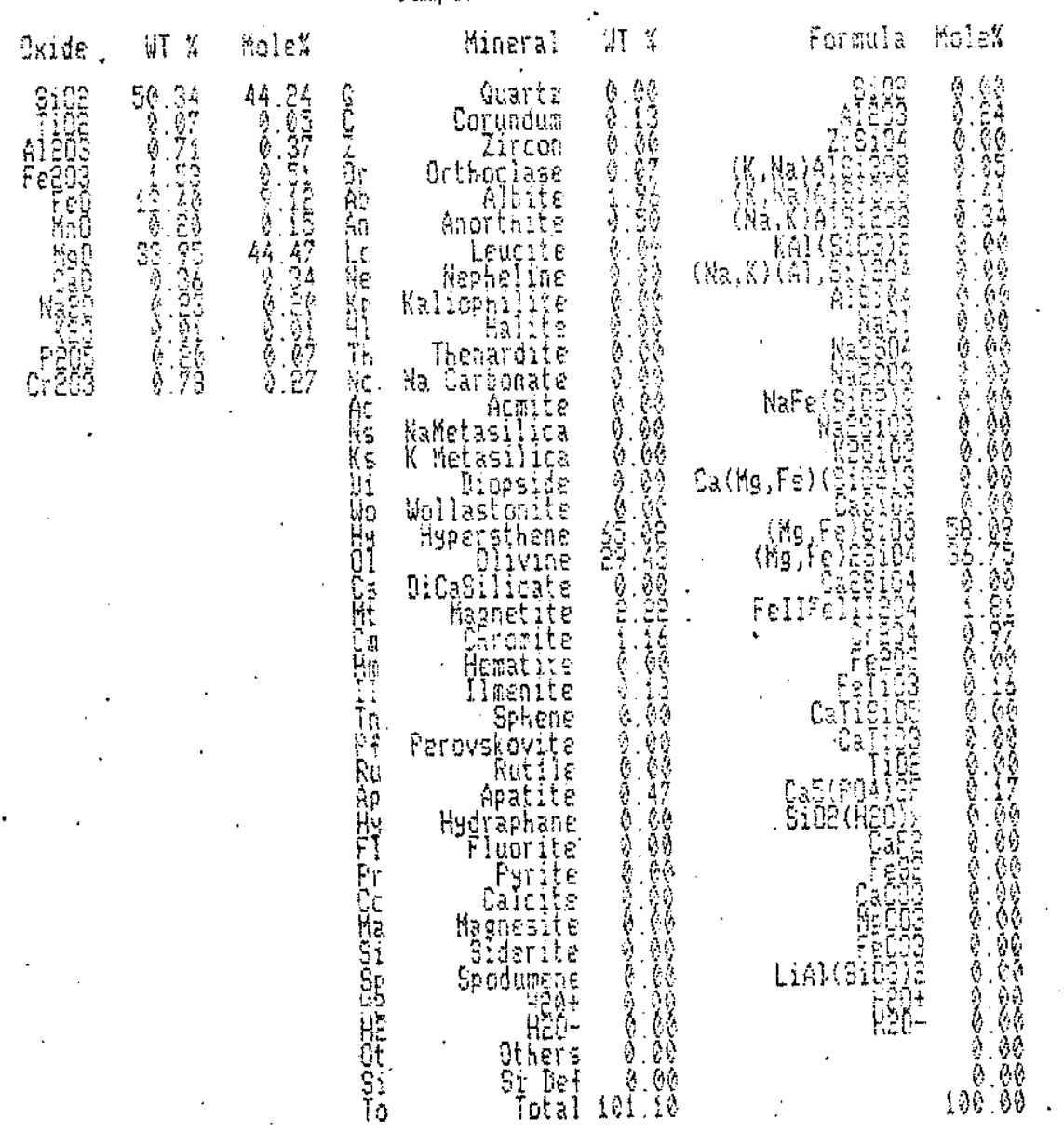

proiection lasta

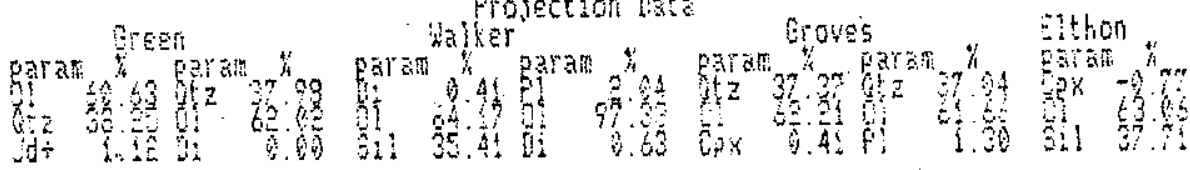




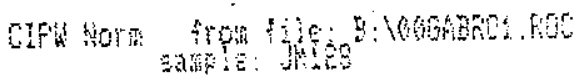

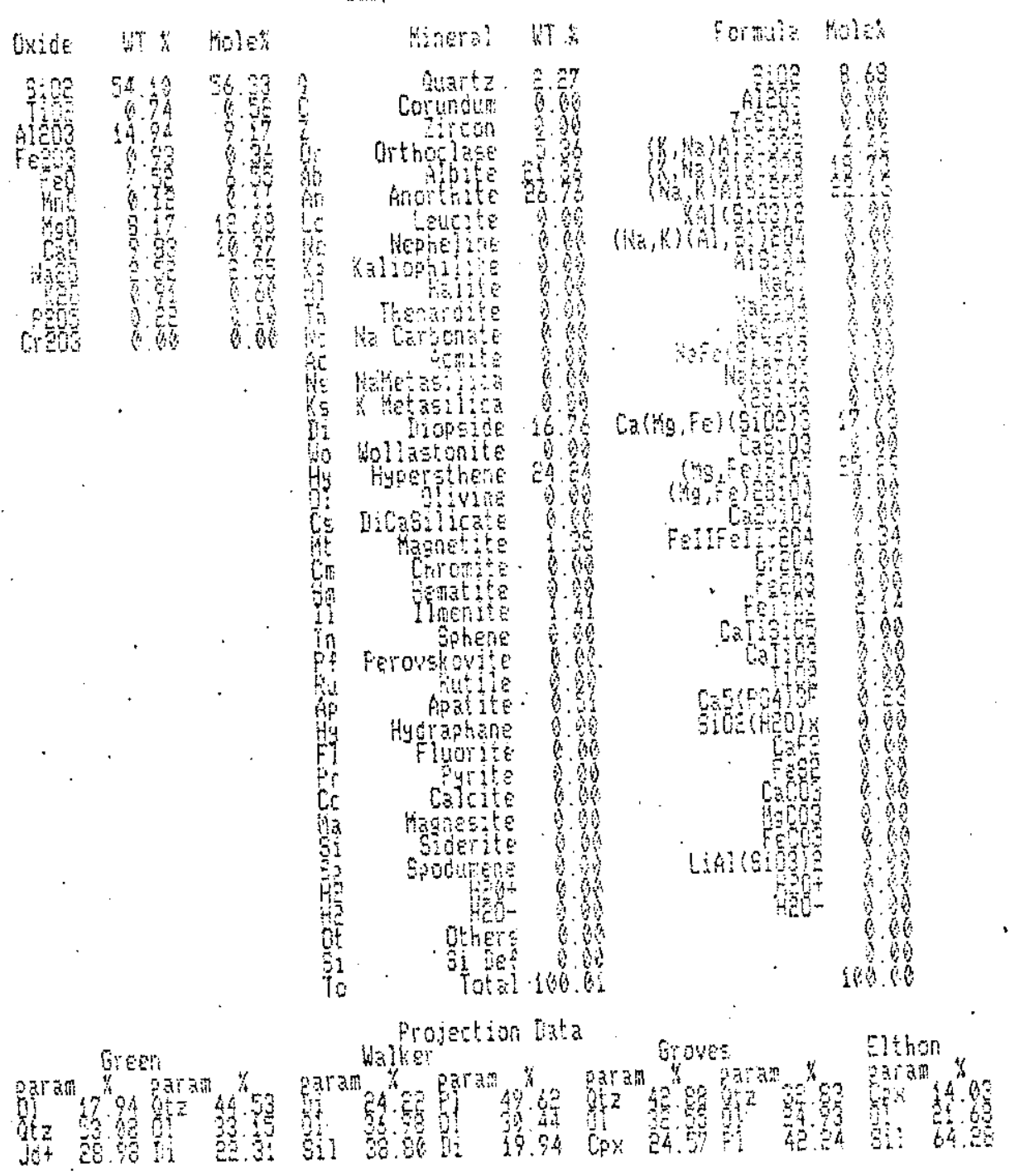




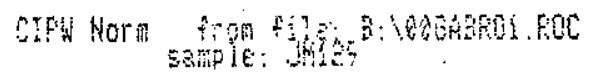

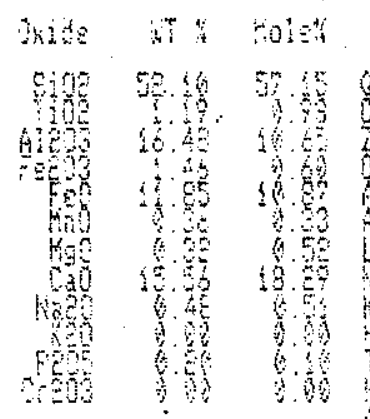

Ginera! H:

Formula rolat

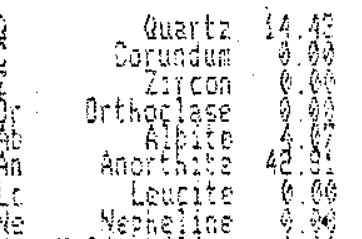

kaliptilite

- 4 in

Whenitite

Ardin?

Hotidita

inose

Wollastorite 0

Hypebthing 40

Dicasijizate

Magrietire

Grogitic

Hentive

seten

Perawisuit Apatits

Hotrathe

furite

catite

midnetse

sporite

mit

$3+\cdots$

ghthe

Total 100.4

An 98

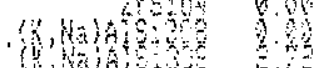

withen 2

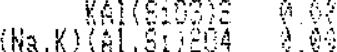

is.

i.

hise

Wefents

not

Ca(ME,FE) (dDO)

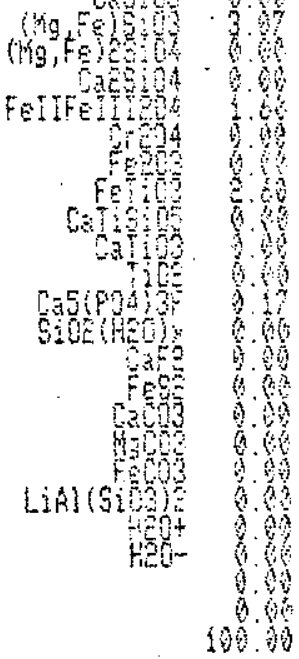

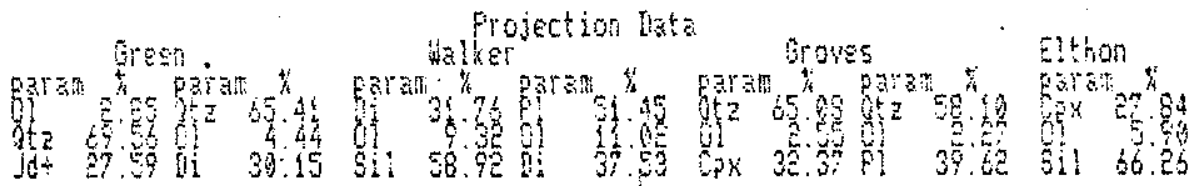




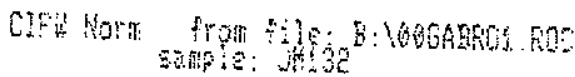
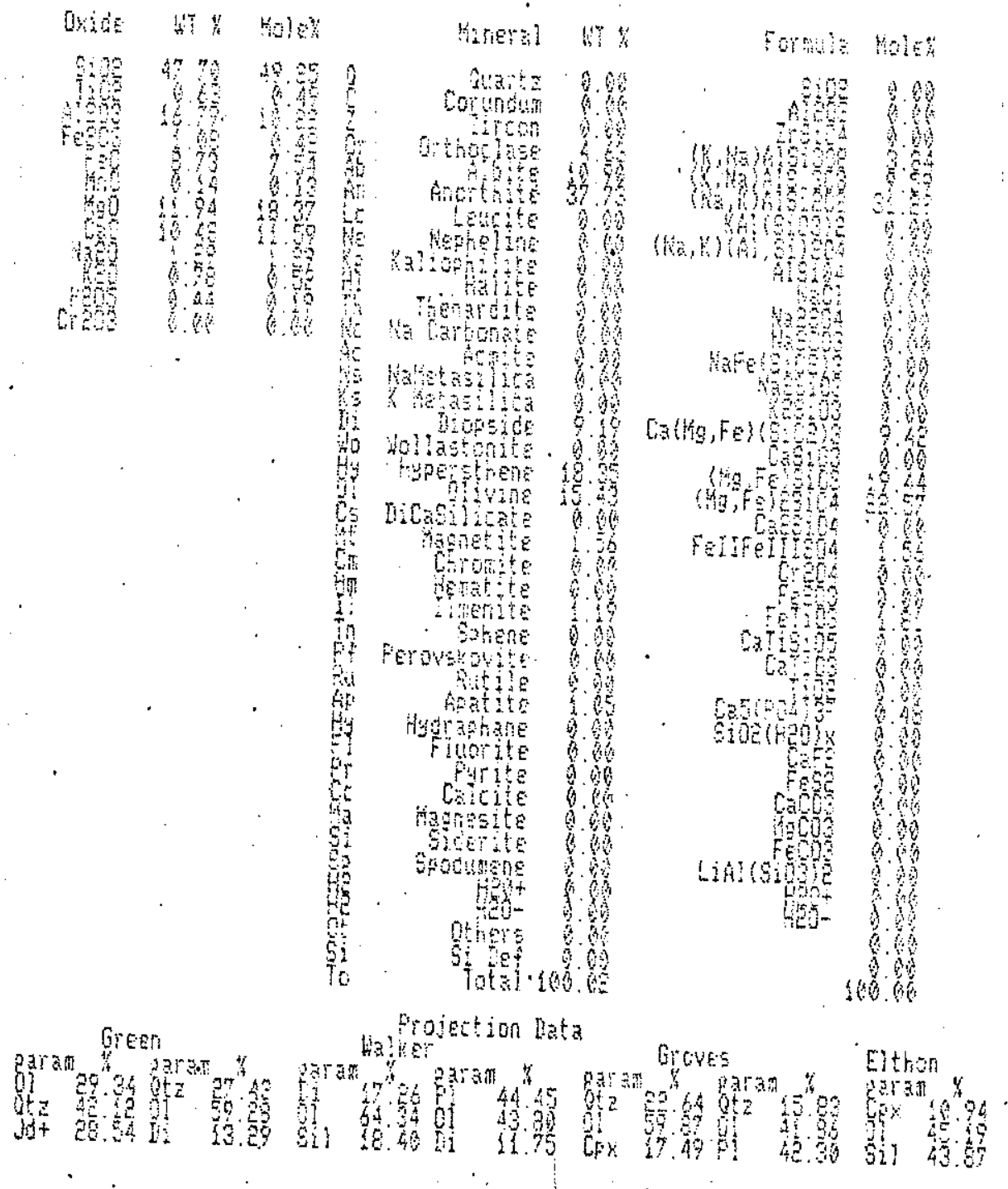
ANEXO 04 


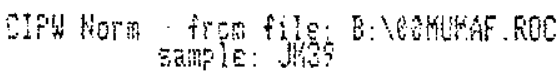

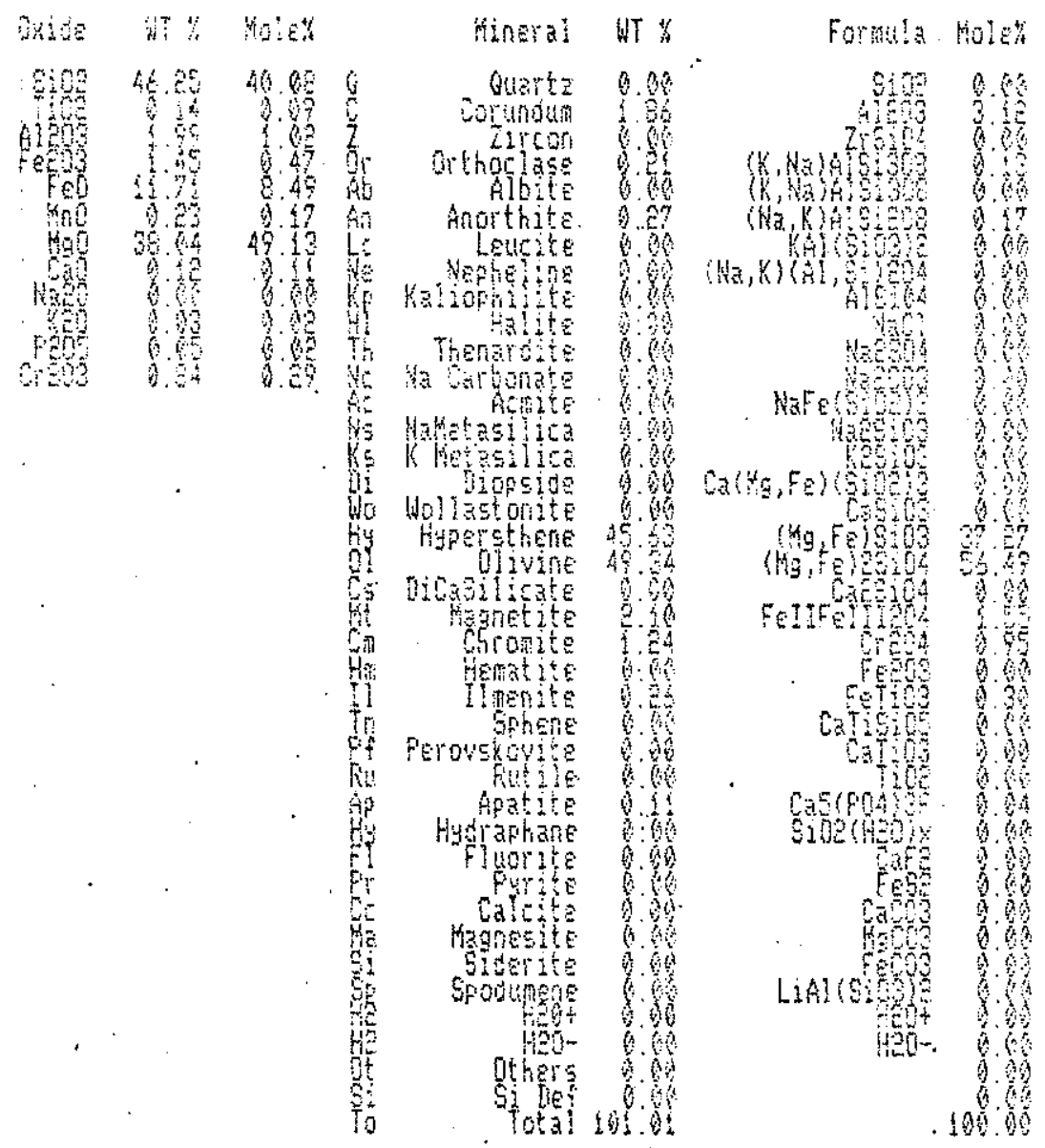

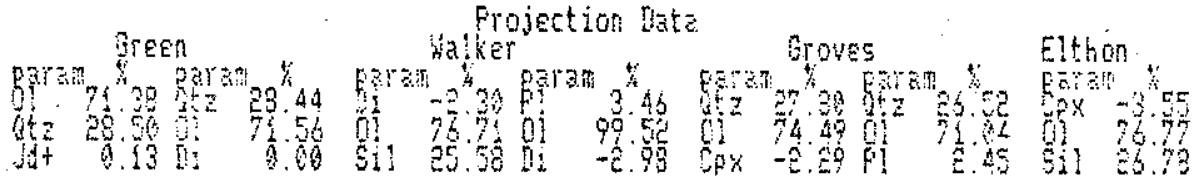




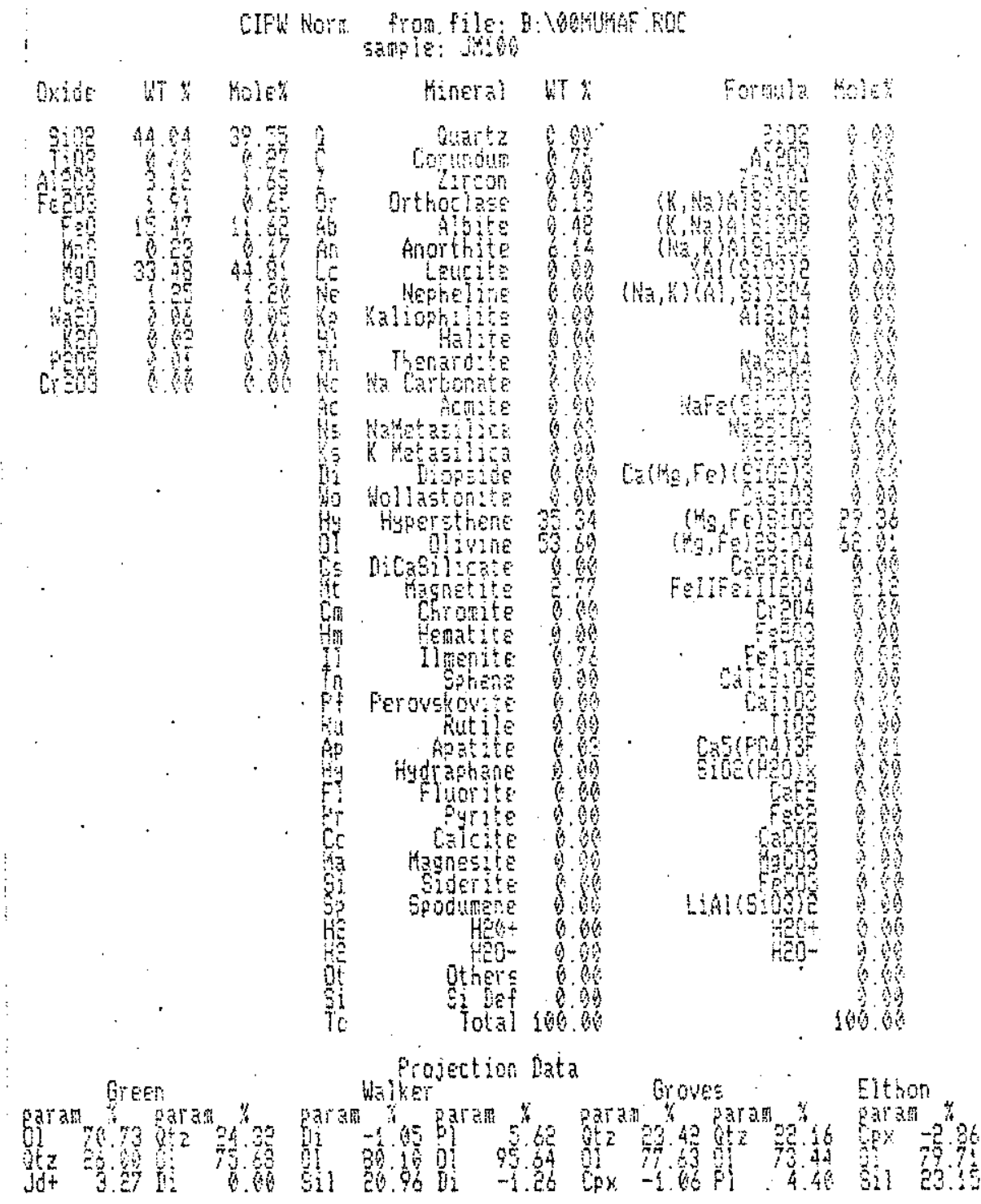


ANEXO 05 


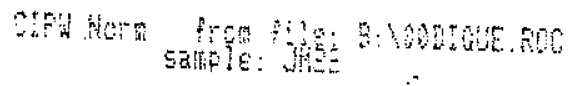
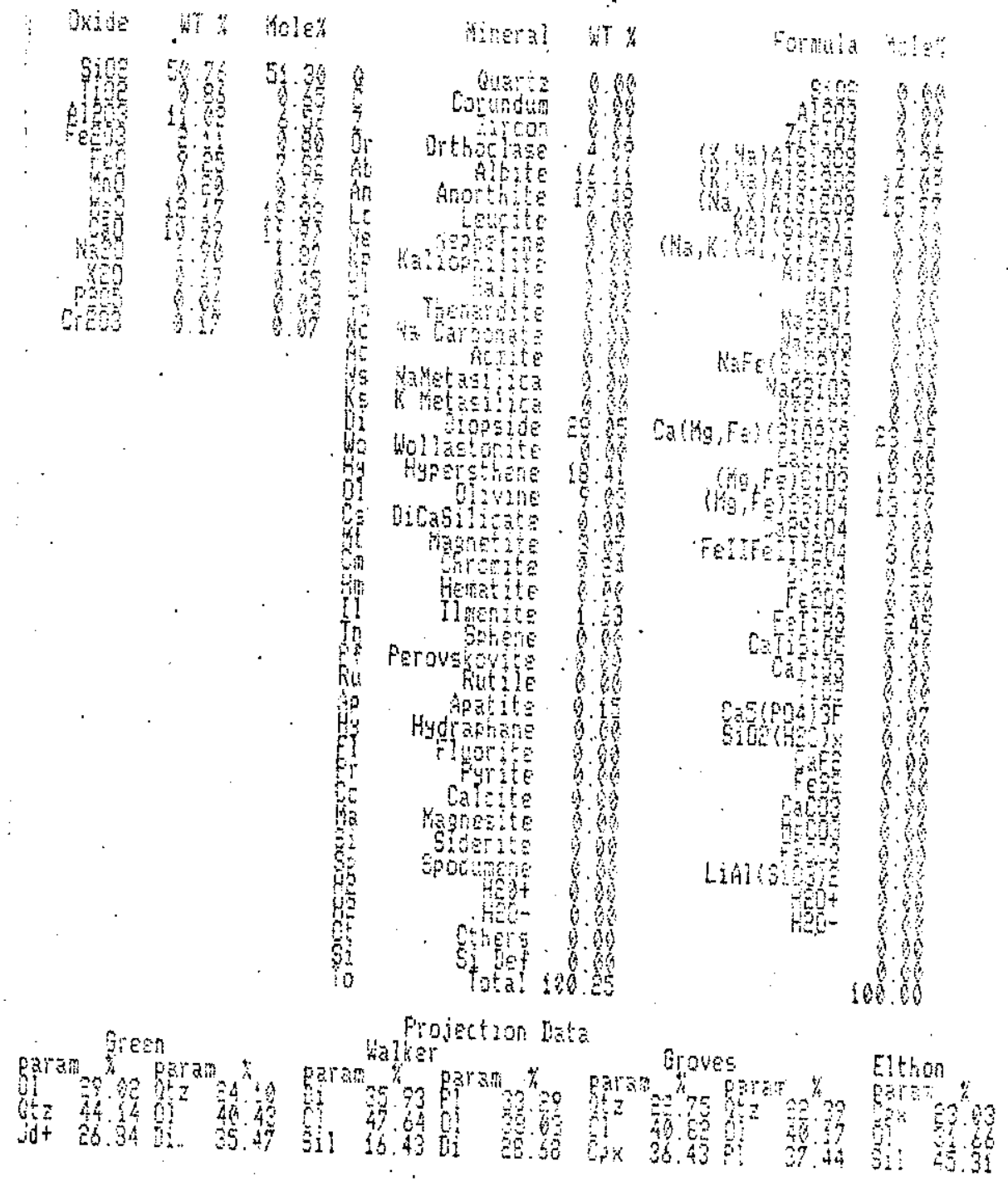


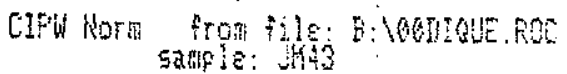

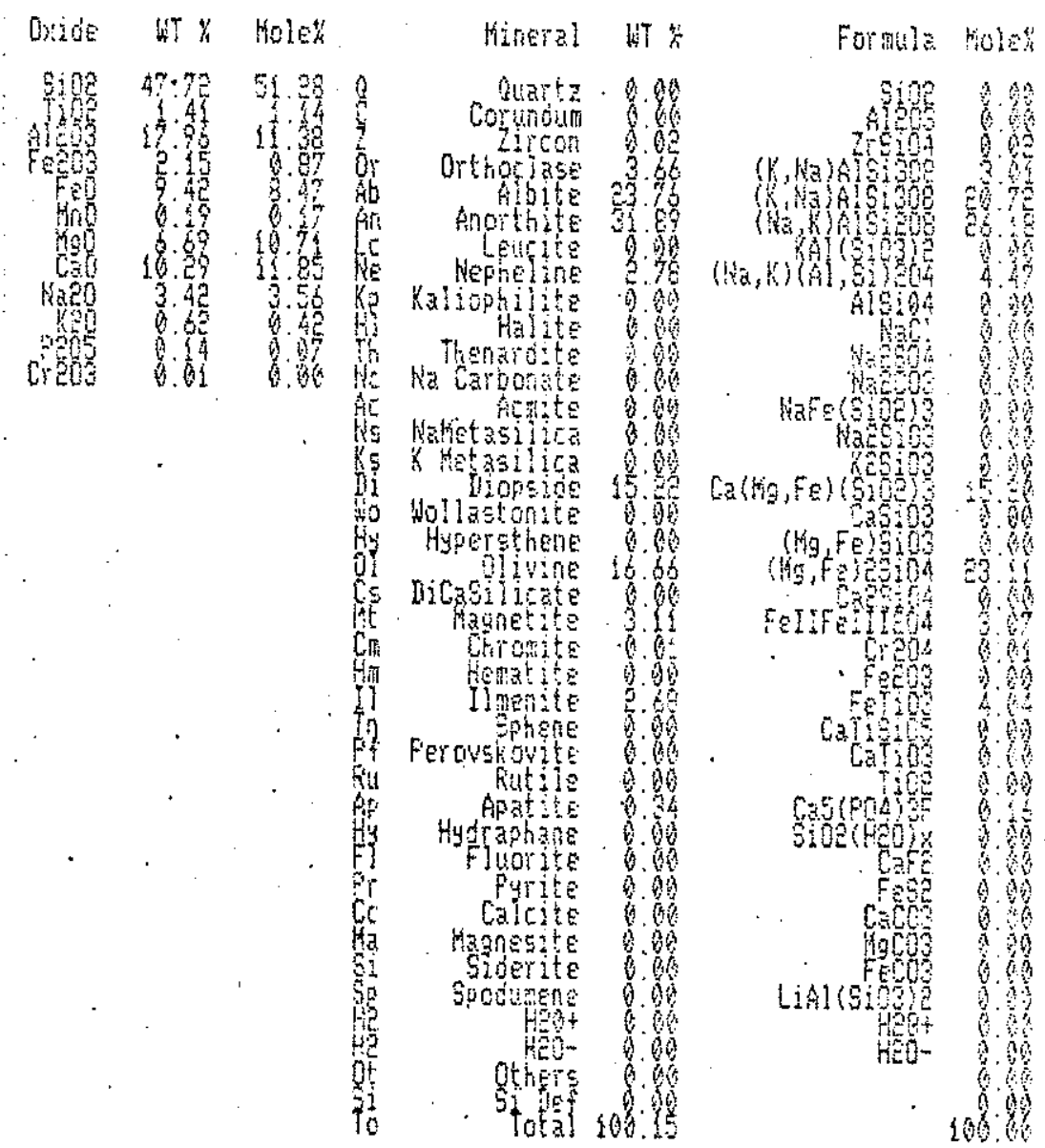

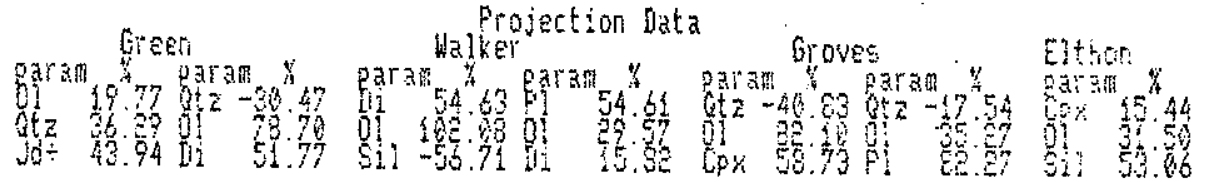


CIf tor trom file 3 : Wontue aOC

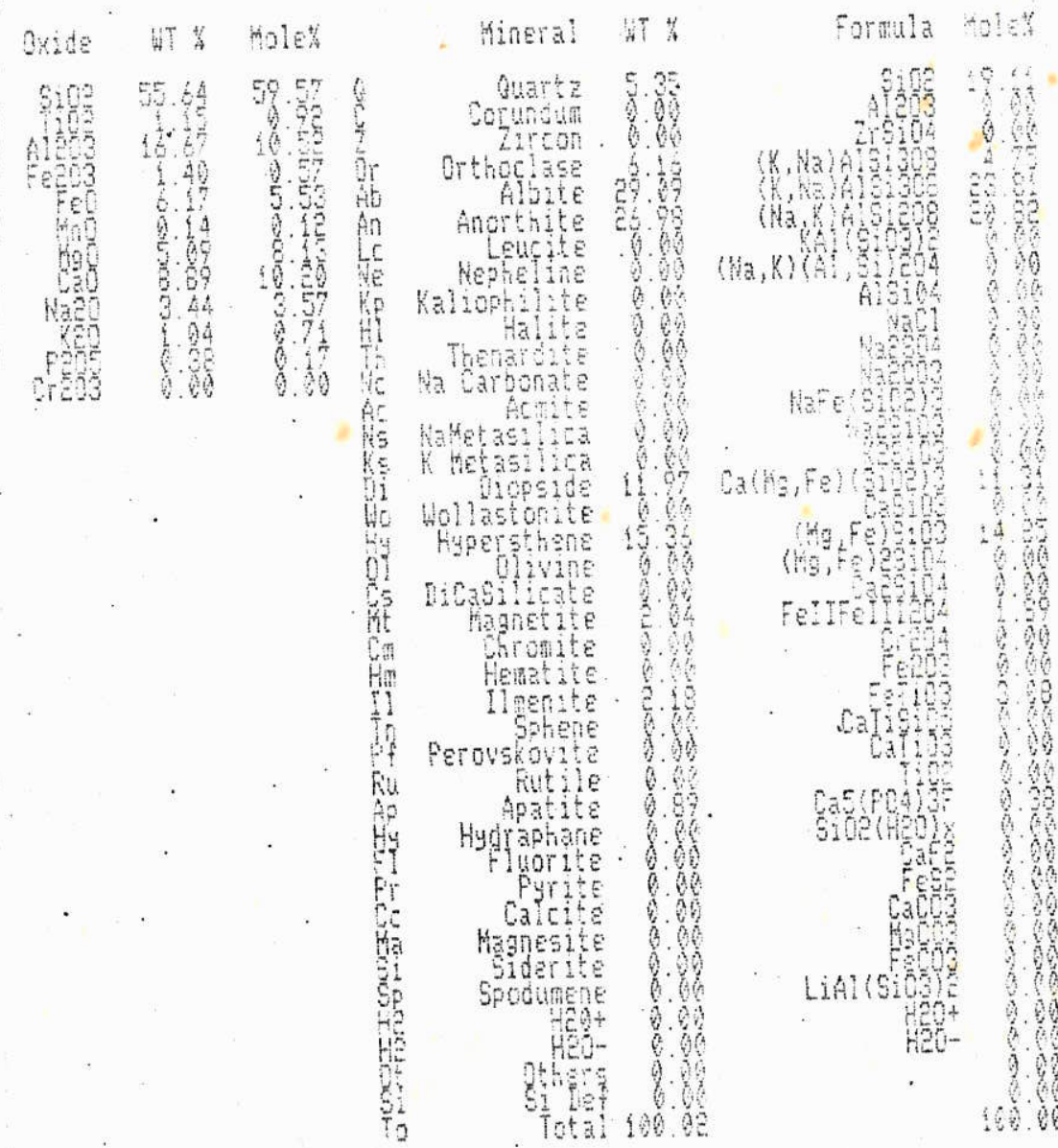

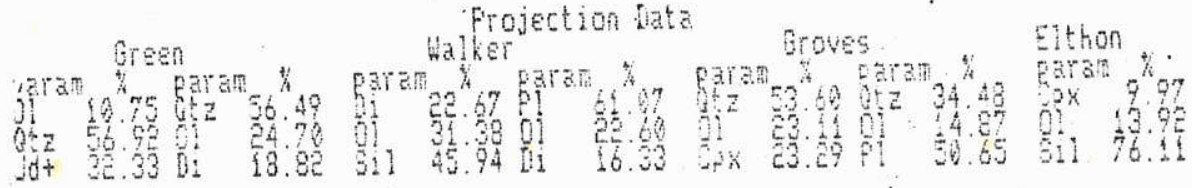

